\title{
Geological Site Characterization for the Proposed Mixed Waste Disposal Facility, Los Alamos National Laboratory
}

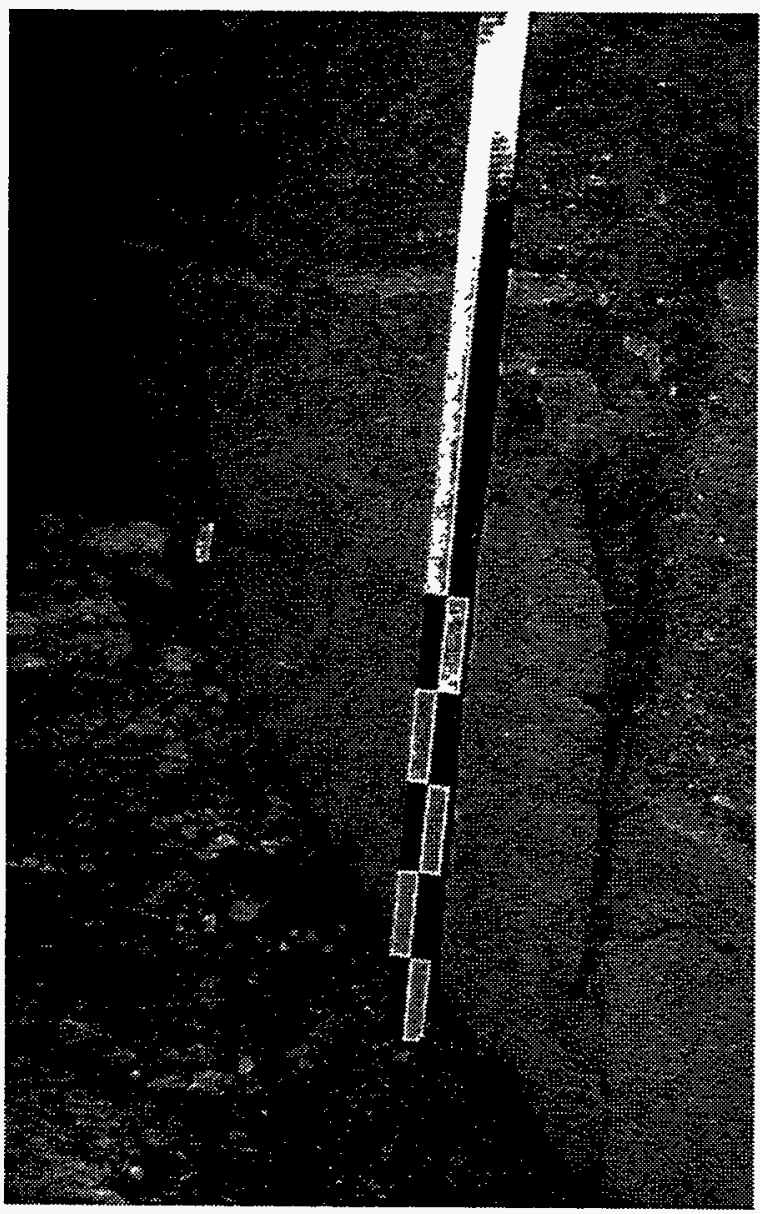

\section{Los Alamos}

\section{NATIONAL LABORATORY}

Los Alamos National Laboratory is operated by the University of California for the United States Department of Enrgy under contract W-7405-ENG-36. 
Cover photo: Photograph of part of a trench excavated on Pajarito Mesa in 1993 as part of fault investigations for the proposed Mixed Waste Disposal Facility. White layer is a volcanic ash bed which is offset $37 \mathrm{~cm}$ down-to-thewest along a north-south trending fault. The ash bed overlies the Bandelier Tuff and underlies early Pleistocene pumice beds which are part of a sequence of mesa-top alluvial deposits. The last movement on this fault was more than 5060,000 years ago. (See chapter by Reneau and others.)

An Affirmative Action/Equal Opportunity Employer

This report was prepared as an account of work sponsored by an agency of the United States Government. Neither The Regents of the University of California, the United States Government nor any agency thereof, nor any of their employees, makes any warranty, express or implied, or assumes any legal liability or responsibility for the accuracy, completeness, or usefulness of any information, apparatus, product, or process disclosed, or represents that its use would not infringe privately owned rights. Reference herein to any specific commercial product, process, or service by trade name, trademark, manufacturer, or otherwise, does not necessarily constitute or imply its endorsement, recommendation, or favoring by The Regents of the University of California, the United States Government, or any agency thereof. The views and opinions of authors expressed herein do not necessarily state or reflect those of The Regents of the University of California, the United States Government, or any agency thereof. 


\title{
Geological Site Characterization
}

for the Proposed Mixed Waste

Disposal Facility,

Los Alamos National Laboratory

\author{
Edited by \\ Steven L. Reneau \\ Robert Raymond, Jr.
}





\section{DISCLAIMER}

Portions of this document may be illegible in electronic image products. Images are produced from the best available original document. 



\section{Contents}

Introduction

by Steven L. Reneau and Robert Raymond, Jr.

Stratigraphy, Mineralogy and Chemistry of Bedrock Tuffs

at Pajarito Mesa

by D. E. Broxton, D. Vaniman, F. M. Byers, Jr., S. J. Chipera, E. C. Kluk, and R. G. Warren

Surficial Materials and Structure at Pajarito Mesa

31

by Steven L. Reneau, Thomas R. Kolbe, David T. Simpson,

John S. Carney, Jamie N. Gardner, Susan S. Olig and David T. Vaniman

Mesa-Penetrating Fractures, Fracture Mineralogy, and

71

Projected Fault Traces at Pajarito Mesa

by David Vaniman and Steve Chipera

Potential Mesa-Edge Instability at Pajarito Mesa

87

by Steven L. Reneau 


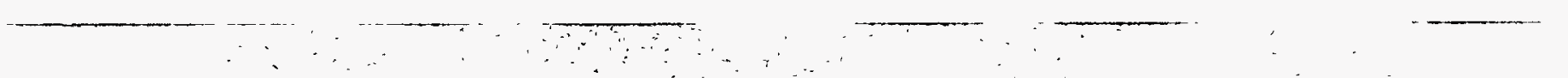




\title{
GEOLOGICAL SITE CHARACTERIZATION FOR THE PROPOSED MIXED WASTE DISPOSAL FACILITY, LOS ALAMOS NATIONAL LABORATORY
}

\author{
Steven L. Reneau and Robert Raymond, Jr. \\ Editors
}

\section{INTRODUCTION}

This report presents the results of geological site characterization studies conducted from 1992 to 1994 on Pajarito Mesa for a proposed Los Alamos National Laboratory Mixed Waste Disposal Facility (MWDF). The MWDF is being designed to receive mixed waste (waste containing both hazardous and radioactive components) generated during Environmental Restoration Project cleanup activities at Los Alamos. As of 1995, there is no Resource Conservation and Recovery Act (RCRA) permitted disposal site for mixed waste at the Laboratory, and construction of the MWDF would provide an alternative to transport of this material to an off-site location.

A site on Pajarito Mesa was chosen for the proposed MWDF after consideration of a variety of factors, including conflicting prior land uses such as buffer zones for Laboratory firing sites, proximity to surface and ground water and to faults, and the occurrence of archaeological sites. A2.5 km long part of Pajarito Mesa was originally considered for the MWDF, extending from an elevation of about 2150 to $2225 \mathrm{~m}$ (7060 to $7300 \mathrm{ft}$ ) in Technical Areas (TAs) 15, 36, and 67 in the central part of the Laboratory, and planning was later concentrated on the western area in TA-67 (Fig. 1). The mesa top lies about 60 to $75 \mathrm{~m} \mathrm{(200} \mathrm{to} 250 \mathrm{ft}$ ) above the floor of Pajarito Canyon on the north, and about $30 \mathrm{~m}$ (100 ft) above the floor of Threemile Canyon on the south. The main aquifer used as a water supply for the Laboratory and for Los Alamos County lies at an estimated depth of about $335 \mathrm{~m}$ (1100 ft) below the mesa (Purtymun and Stoker, 1988).

The chapters of this report focus on surface and near-surface geological studies that provide a basic framework for siting of the MWDF and for conducting future performance assessments, including fulfillment of specific regulatory requirements. This work includes detailed studies of the stratigraphy, mineralogy, and chemistry of the bedrock at Pajarito Mesa by Broxton and others, studies of the geological structure and of mesa-top soils and surficial deposits by Reneau and others, geologic mapping and studies of fracture characteristics by Vaniman and Chipera, and studies of potential landsliding and rockfall along the mesa-edge by Reneau. The latter work focused on recommending appropriate setbacks from the mesa edge for the disposal pits.

One major goal of these studies was the evaluation of potential young faulting at Pajarito Mesa. The Code of Federal Regulations, Title 40 (40 CFR), 264.18(a) requires that portions of new facilities where treatment, storage, or disposal of hazardous (including mixed) waste occur will not be

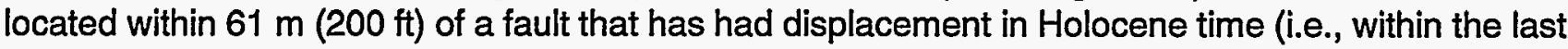
11,000 years). Previous geological mapping had inferred that the southern projections of the Rendija Canyon and Guaje Mountain faults crossed Pajarito Mesa (Vaniman and Wohletz, 1990), and paleoseismic studies had indicated that both of these faults had possibly produced surface-rupturing earthquakes in the last 11,000 years to the north (Gardner et al., 1990; Wong et al., 1995). However, many uncertainties existed concerning the exact location and history of faults in this part of the Laboratory, and much of the work discussed by Vaniman and Chipera and by Reneau and others was undertaken to determine if the site met the requirements of 40 CFR 264.18. In addition, 40 CFR 270.14(b)(11)(ii)(B) specifies that data shall be obtained from a subsurface exploration (trenching) if other site analysis is inconclusive as to the location and age of faulting within $61 \mathrm{~m}$ of the facility. The 
chapter by Reneau and others includes a summary of extensive exploratory trenching that was mainly performed by Woodward-Clyde Federal Services, and which is presented in more detail by Kolbe et al. (1994).

The work by Broxton and others and by Vaniman and Chipera have direct application to performance assessment activities for the proposed MWDF. The detailed stratigraphy discussed by Broxton and others will aid in identifying rock units penetrated by core holes and in modeling potential subsurface transport, and the chemical data provide a baseline which can be used to detect any transport of contaminants into the tuff. Examination of fractures by Vaniman and Chipera provides key evidence as to the processes of vadose zone transport in the upper tuff units, which will also aid in modeling efforts.

The studies described in this report also contribute to fulfillment of the requirements of the Laboratory's RCRA operating permit. Specifically, Section Q, Task III, Subtask A.1 of the Hazardous and Solid Waste Act (HSWA) module (EPA, 1994), requires a program to evaluate site hydrogeologic conditions, including description of hydrogeologic units that may influence contaminant migration pathways, analysis of fractures, and preparation of geologic cross sections. The studies of bedrock stratigraphy and fractures in this report directly address these permit requirements.

Although the work discussed in this report was focused on meeting the needs of the MWDF, it has substantial bearing on understanding bedrock characteristics, fractures, faults, soils, and cliff retreat processes in the central part of the Laboratory, which in turn will have application in a variety of activities at the Laboratory. The detailed study of the Bandelier Tuff at Pajarito Mesa by Broxton and others, in combination with other recent studies (e.g., Broxton et al., 1995), reveal significant eastwest variations in physical properties of the tuff which will strongly influence their hydrologic properties. Data on fracture characteristics in both trench exposures and cliff faces presented by Reneau and others and by Vaniman and Chipera have bearing on understanding the relation of fractures to faulting, bedrock stratigraphy, and subsurface transport at other sites. These studies also provide key data on the southern terminations of the Rendija Canyon and Guaje Mountain faults, which will aid in understanding seismic hazards at the Laboratory. The trenches of Kolbe et al. (1994), discussed by Reneau and others, also provided an exceptional exposure of undisturbed soils that allow unique insights into soil age, soil development, soil variability, and long-term surface erosion on mesas at the Laboratory. Finally, the study of cliff retreat processes by Reneau should aid in evaluating the stability of mesa edges at other sites in the Laboratory.

\section{REFERENCES}

Broxton, D. E., Heiken, G. H., Chipera, S. J., and Byers, F. M., Jr., 1995, Stratigraphy, petrography, and mineralogy of Bandelier Tuff and Cerro Toledo deposits: in Broxton, D. E., and Eller, P. G., eds., Earth Science Investigations For Environmental Restoration-Los Alamos National Laboratory Technical Area 21: Los Alamos National Laboratory Report LA-12934-MS, Los Alamos, New Mexico, p. 33-63.

EPA, 1994, Module VIII: Special Conditions Pursuant to the 1984 Hazardous and Solid Waste Amendments to RCRA for Los Alamos National Laboratory, EPA I.D. NM0890010515, issued by U.S. Environmental Protection Agency Region 6, modifications effective May 29, 1994.

Gardner, J. N., Baldridge, W. S., Gribble, R., Manley, K., Tanaka, K., Geissman, J. W., Gonzalez, M., and Baron, G., 1990, Results from Seismic Hazards Trench \#1 (SHT-1) Los Alamos Seismic Hazards Investigations: Los Alamos National Laboratory Memorandum No. EES1-SH90-19, Los Alamos, New Mexico.

Kolbe, T., Sawyer, J., Gorton, A., Olig, S., Simpson, D., Fenton, C., Reneau, S., Carney, J., Bott, J., and Wong, I., 1994, Evaluation of the Potential for Surface Faulting at the Proposed Mixed Waste Disposal Facility, TA-67: unpublished report, Woodward-Clyde Federal Services, Oakland, California, 3 volumes. 
Purtymun, W. D., and Stoker, A. K., 1988, Water supply at Los Alamos: Current status of wells and future water supply: Los Alamos National Laboratory Report LA-11332-MS, Los Alamos, New Mexico.

Vaniman, D., and Wohletz, K., 1990, Results of geological mapping/fracture studies: TA-55 area: Los Alamos National Laboratory Memorandum EES1-SH90-17, Los Alamos, New Mexico, 23 p.

Wong, I., Kelson, K., Olig, S., Kolbe, T., Hemphill-Haley, M., Bott, J., Green, R., Kanakari, H., Sawyer, J., Silva, W., Stark, C., Haraden, C., Fenton, C., Unruh, J., Gardner, J., Reneau, S., and House, L., 1995, Seismic Hazards Evaluation of the Los Alamos National Laboratory: unpublished report, Woodward-Clyde Federal Services, Oakland, California, 3 volumes.

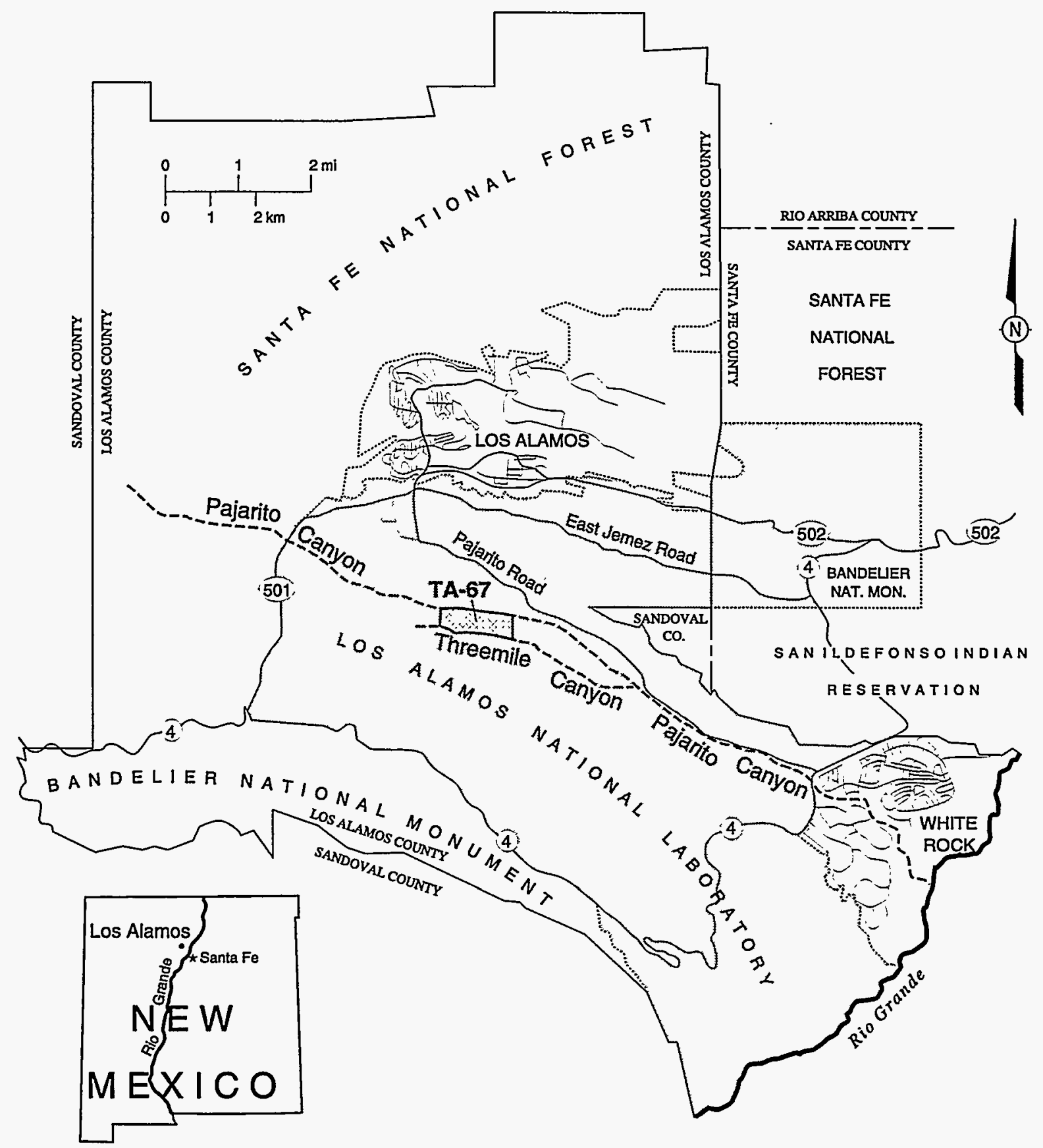

Fig. 1. Map showing location of TA-67, the proposed site for the Mixed Waste Disposal Facility. 


\title{
STRATIGRAPHY, MINERALOGY AND CHEMISTRY OF BEDROCK TUFFS AT PAJARITO MESA
}

\author{
by \\ D. E. Broxton, D. Vaniman, F. M. Byers, Jr., \\ S. J. Chipera, E. C. Kluk, and R. G. Warren \\ Geology/Geochemistry Group \\ Los Alamos National Laboratory
}

\begin{abstract}
This study was conducted as part of on-going Environmental Restoration Program efforts to site and construct a Mixed Waste Disposal Facility at Pajarito Mesa, Los Alamos National Laboratory. Stratigraphic sections were measured in bedrock units exposed on the north walls of Threemile and Pajarito Canyons to provide geologic information about the tuffs that underlie Pajarito Mesa. Selected samples from these stratigraphic sections were analyzed by X-ray diffraction for mineralogy, $X$-ray fluorescence for chemistry, and microscopy for petrography. Cross sections were prepared based on the stratigraphic sections, and the strike and dip of the tuff was estimated by a three-point graphical solution.

The Tshirege Member of the Bandelier Tuff is a multiple-flow ash-flow sheet that forms prominent cliffs and benches at Pajarito Mesa. It is a compound cooling unit characterized by zonal patterns of welding and crystallization which result in physical properties that vary both vertically and laterally. The exposed portion of the Tshirege Member consists of Qbt 2 - a lower, hard, cliff-forming unit in the canyon bottoms and Qbt 3 - which consists of a lower nonwelded part that forms a broad sloping bench, and an upper welded part that forms the caprock of Pajarito Mesa. In the western part of the study area, the caprock is overlain by Qbt 4 , a thin nonwelded to partially-welded sequence of shardy tuffs that forms a low ridge along the mesa centerline.

The bulk rock mineralogy of the Tshirege Member at Pajarito Mesa consists primarily of alkali feldspar, tridymite, quartz, and cristobalite. Trace minerals include smectite, hematite, calcite, hornblende, and mica.

Tuff compositions range from high-silica rhyolite $\left(77 \% \mathrm{SiO}_{2}\right)$ in units 2 and 3 to rhyolite $\left(74 \% \mathrm{SiO}_{2}\right)$ in unit 4 . Trace elements compositions vary as a function of stratigraphic height in units 2 through 4 , but the most pronounced changes take place across the Qbt $3 /$ Qbt 4 contact.
\end{abstract}




\section{INTRODUCTION}

This study was conducted as part of on-going Environmental Restoration (ER) Program efforts to site and construct a Mixed Waste Disposal Facility (MWDF) at Los Alamos National Laboratory. Pajarito Mesa is being investigated as a possible location to host this facility. Data presented in this report support the site selection and licensing of the MWDF by providing geological information that is specific to Pajarito Mesa. These studies were conducted in conjunction with other geologic studies to develop a geological conceptual model for the site, to evaluate potential ground water pathways and processes, and to provide geological data specifically required for licensing. In addition, the geologic information from this study can be used to support the design and construction of waste pits, monitoring systems, and support facilities.

These studies began in 1992, and at that time three candidate sites on Pajarito Mesa (sites PS-1, -2, and -3; Fig. 1) were being considered for a Mixed Waste Disposal Facility. This report presents data for all three sites, although the candidate site was narrowed to PS-1 in late 1992.

This study describes the bedrock geology of Pajarito Mesa and its adjacent canyons. Vaniman and Chipera (this report) present a geologic map of the site and characterize fractures and their infillings. Surficial deposits and faults were determined by extensive trench studies along the centerline of the mesa by Kolbe et al. (1994) (see also Reneau et al., this report). A report that includes subsurface geology and hydrologic setting of the site was compiled for a radiological performance assessment by Turin and Rosenberg (1993).

\section{METHODS}

Five stratigraphic sections (stratigraphic sections STRAT-1 to STRAT-5) were measured in bedrock units exposed on the north walls of Threemile and Pajarito Canyons (Fig. 1). A sixth stratigraphic section (S-3), measured as part of a seismic hazards study for TA-55 (Vaniman and Wohletz, 1990), is also incorporated into this study. The stratigraphic sections are located such that they form three north-south pairs. These north-south pairs were used to construct cross sections across each of three study areas (PS-1, PS-2, and PS-3) which were originally considered as potential sites for a MWDF (Fig. 1). These cross sections provide information about the distribution of tuffs that underlie Pajarito Mesa. Together, the geologic map (Vaniman and Chipera, this report) and the stratigraphic data presented in this report provide a geologic framework for understanding the distribution of rock units at Pajarito Mesa.

LANL-ER-SOP-03.07 (Characterization of Lithologic Variations within the Rock Outcrops of a Volcanic Field) is the procedure under which the field work was performed. Field observations in each stratigraphic section generally included descriptions of rock type, unit thickness, type and degree of alteration, welding and compaction, phenocryst assemblage and abundance, color on fresh and weathered surfaces, pumice size and abundance, and weathering characteristics. Bedding characteristics, fractures and their filling materials, and lithic assemblage, size, and abundance were also noted. Bulk-tuff samples were collected at a nominal vertical spacing of $5 \mathrm{~m}$ or at major changes in lithology. Metal tags mark sample sites in the field. Initially, vertical control was maintained by Jacob staff and Abney level. Later, Merrick \& Company surveyed locations and elevations of sample sites (Table 1).

Major and trace elements were analyzed in samples using an automated Rigaku wavelengthdispersive X-ray fluorescence (XRF) spectrometer. Samples were prepared by crushing and homogenizing 15-20 $\mathrm{g}$ of the sample in a shatterbox in accordance with Yucca Mountain Project procedure LANL-EES-DP-130 (Geologic Sample Preparation). Sample splits were heated at $110^{\circ} \mathrm{C}$ for $24 \mathrm{hrs}$, and then $4 \mathrm{~g}$ splits were fused at $1100^{\circ} \mathrm{C}$ with $8 \mathrm{~g}$ of lithium metaborate/lithium tetraborate flux. Elemental concentrations were calculated by comparing $X$-ray intensities for the samples to 


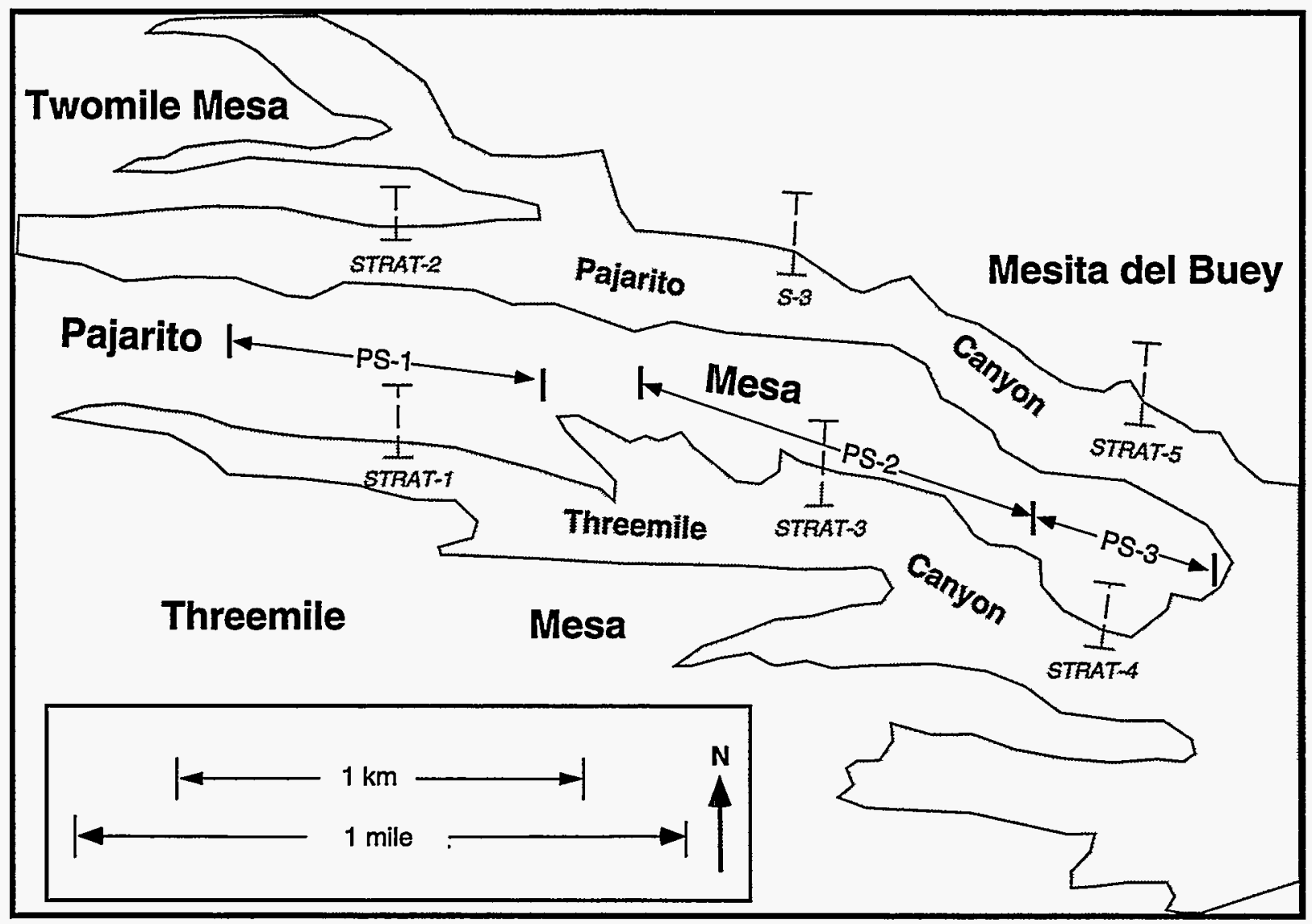

Figure 1. Map of Pajarito Mesa showing Jocations of study areas PS-1, PS-2, and PS-3 and of stratigraphic sections STRAT-1, $-2,-3,-4,-5$, and S-3.

those for 21 standards of known composition. A fundamental parameters program was used for matrix corrections (Criss, 1980) in accordance with Yucca Mountain Project procedure LANL-EESDP-111.

The mineralogy of the tuffs was determined by X-ray diffraction (XRD) for 41 samples collected from stratigraphic sections STRAT-1,-2, and -3 . Samples were first powdered in a tungstencarbide shatter box and then mixed with an internal standard of $1 \mu \mathrm{m}$ metallurgical grade $\mathrm{Al}_{2} \mathrm{O}_{3}$ (corundum) powder in a ratio of $80 \%$ sample to $20 \%$ internal standard by weight. The samples were then ground under acetone in an automatic Brinkmann-Retsch mill fitted with an agate mortar and pestle to produce an average particle size of less than $5 \mu \mathrm{m}$. This fine particle size is necessary to ensure adequate particle statistics and to minimize primary extinction (Klug and Alexander, 1974, pp. 365-367). Particle size distributions have been verified using a Horiba CAPA-500 centrifugal particle size distribution analyzer calibrated with Duke Scientific glass microsphere standards. X-ray diffraction (XRD) data were collected on a Siemens D-500 theta-theta diffractometer using copper-K $\alpha$ radiation, incident- and diffracted-beam Soller slits, and a Kevex solid-state (SiLi) detector. Data were typically collected from 2.0 to $50.0^{\circ} 2 \theta$ using a $0.02^{\circ}$ step size and at least two seconds per step. Quantitative analyses employed the internal standard or "matrix-flushing" method of Chung (1974a,b). Details for analysis can be found in Bish and Chipera (1988; 1989). In addition, the following Yucca Mountain Project procedures were used for sample preparation and analysis of XRD samples: LANL-EES-DP-130 (Geologic Sample Preparation), LANL-EES-DP-56 (Brinkmann Automated Grinder Procedure), LANL-EES-DP-16 (Siemens X-Ray Diffraction 
Table 1. Locations of Samples Collected in Stratigraphic Sections at Pajarito Mesa, Los Alamos, New Mextco ${ }^{1}$

\begin{tabular}{|c|c|c|c|c|c|}
\hline Sample Number & Strat. Unit ${ }^{2}$ & Site ID & North (ft.) & East (ft.) & El. (ft.) \\
\hline $\begin{array}{l}\text { OU-1085-STRAT1-1 } \\
\text { OU-1085-STRAT1-2 } \\
\text { OU-1085-STRAT1-3A } \\
\text { OU-1085-STRAT1-3B } \\
\text { OU-1085-STRAT1-4 } \\
\text { OU-1085-STRAT1-5 } \\
\text { OU-1085-STRAT1-6 } \\
\text { OU-1085-STRAT1-7 } \\
\text { OU-1085-STRAT1-8 } \\
\text { OU-1085-STRAT1-9A } \\
\text { OU-1085-STRAT1-9B } \\
\text { OU-1085-STRAT1-9C } \\
\text { OU-1085-STRAT1-10 }\end{array}$ & $\begin{array}{l}\text { Qbt 2 } \\
\text { Qbt 3(u) } \\
\text { Qbt 3(u) } \\
\text { Qbt 3(u) } \\
\text { Qbt 3(u) } \\
\text { Qbt 3(u) } \\
\text { Qbt 3(u) } \\
\text { Qbt 3(u) } \\
\text { Qbt 3(u) } \\
\text { Qbt 3(u) } \\
\text { Qbt 4 } \\
\text { Qbt } 4 \\
\text { Qbt } 4\end{array}$ & $\begin{array}{l}67-1001 \\
67-1002 \\
67-1003 \\
67-1004 \\
67-1005 \\
67-1006 \\
67-1007 \\
67-1008 \\
67-1009 \\
67-1010 \\
67-1011 \\
67-1012 \\
67-1013\end{array}$ & $\begin{array}{l}1764625 \\
1764694 \\
1764761 \\
1764761 \\
1764790 \\
1764790^{3} \\
1764801 \\
1764901 \\
1765134 \\
1765209 \\
1765209 \\
1765209 \\
1765277\end{array}$ & $\begin{array}{l}1623831 \\
1623796 \\
1623786 \\
1623786 \\
1623793 \\
1623793^{3} \\
1623791 \\
1623780 \\
1623709 \\
1623684 \\
1623684 \\
1623684 \\
1623722\end{array}$ & $\begin{array}{l}7115 \\
7136 \\
7162 \\
7162 \\
7192 \\
7200^{3} \\
7209 \\
7227 \\
7243 \\
7249 \\
7249 \\
7249 \\
7266\end{array}$ \\
\hline $\begin{array}{l}\text { OU-1085-STRAT2-01 } \\
\text { OU-1085-STRAT2-02 } \\
\text { OU-1085-STRAT2-03 } \\
\text { OU-1085-STRAT2-04 } \\
\text { OU-1085-STRAT2-05 } \\
\text { OU-1085-STRAT2-06 } \\
\text { OU-1085-STRAT2-07 } \\
\text { OU-1085-STRAT2-08 } \\
\text { OU-1085-STRAT2-09 } \\
\text { OU-1085-STRAT2-10 } \\
\text { OU-1085-STRAT2- } 11 \\
\text { OU-1085-STRAT2-12 } \\
\text { OU-1085-STRAT2-13 } \\
\text { OU-1085-STRAT2-14 }\end{array}$ & $\begin{array}{l}\text { Qbt 2 } \\
\text { Qbt 2 } \\
\text { Qbt 2 } \\
\text { Qbt 2 } \\
\text { Qbt 2 } \\
\text { Qbt 2 } \\
\text { Qbt 3(u) } \\
\text { Qbt 3(u) } \\
\text { Qbt 3(u) } \\
\text { Qbt 3(u) } \\
\text { Qbt 3(u) } \\
\text { Qbt 3(u) } \\
\text { Qbt 3(u) } \\
\text { Qbt 4 }\end{array}$ & $\begin{array}{l}67-1014 \\
67-1015 \\
67-1016 \\
67-1017 \\
67-1018 \\
67-1019 \\
67-1020 \\
67-1021 \\
67-1022 \\
67-1023 \\
67-1024 \\
67-1025 \\
67-1026 \\
67-1027\end{array}$ & $\begin{array}{l}1766467 \\
1766482 \\
1766486 \\
1766514 \\
1766545 \\
1766562 \\
1766642 \\
1766719 \\
1766754 \\
1766769 \\
1766781 \\
1766820 \\
1767000 \\
1767040\end{array}$ & $\begin{array}{l}1623591 \\
1623596 \\
1623573 \\
1623577 \\
1623568 \\
1623534 \\
1623567 \\
1623487 \\
1623550 \\
1623559 \\
1623564 \\
1623544 \\
1623512 \\
1623494\end{array}$ & $\begin{array}{l}7056 \\
7073 \\
7088 \\
7104 \\
7121 \\
7138 \\
7150 \\
7185 \\
7200 \\
7215 \\
7229 \\
7246 \\
7264 \\
7271\end{array}$ \\
\hline $\begin{array}{l}\text { OU-1085-STRAT3-1 } \\
\text { OU-1085-STRAT3-2 } \\
\text { OU-1085-STRAT3-3 } \\
\text { OU-1085-STRAT3-4 } \\
\text { OU-1085-STRAT3-5 } \\
\text { OU-1085-STRAT3-6 } \\
\text { OU-1085-STRAT3-7A } \\
\text { OU-1085-STRAT3-7B } \\
\text { OU-1085-STRAT3-8 } \\
\text { OU-1085-STRAT3-9 } \\
\text { OU-1085-STRAT3-10 } \\
\text { OU-1085-STRAT3-11 } \\
\text { OU-1085-STRAT3-12 } \\
\text { OU-1085-STRAT3-13 }\end{array}$ & $\begin{array}{l}\text { Qbt 2 } \\
\text { Qbt 2 } \\
\text { Qbt 2 } \\
\text { Qbt 2 } \\
\text { Qbt 2 } \\
\text { Qbt 3(l) } \\
\text { Qbt 3(l) } \\
\text { Qbt 3(l) } \\
\text { Qbt 3(u) } \\
\text { Qbt 3(u) } \\
\text { Qbt 3(u) } \\
\text { Qbt 3(u) } \\
\text { Qbt 3(u) } \\
\text { Qbt 3(u) }\end{array}$ & $\begin{array}{l}67-1028 \\
67-1029 \\
67-1030 \\
67-1031 \\
67-1032 \\
67-1033 \\
67-1034 \\
67-1035 \\
67-1036 \\
67-1037 \\
67-1038 \\
67-1039 \\
67-1040 \\
67-1041\end{array}$ & $\begin{array}{l}1763968 \\
1764000 \\
1764008 \\
1764072 \\
1764180 \\
1764339 \\
1764411 \\
1764411 \\
1764432 \\
1764436 \\
1764467 \\
1764484 \\
1764513 \\
1764715\end{array}$ & $\begin{array}{l}1628013 \\
1627979 \\
1627997 \\
1627999 \\
1627976 \\
1628056 \\
1627968 \\
1627968 \\
1627971 \\
1627976 \\
1627983 \\
1627982 \\
1627984 \\
1627988\end{array}$ & $\begin{array}{l}6958 \\
6971 \\
6988 \\
7004 \\
7021 \\
7036 \\
7058 \\
7058 \\
7064 \\
7081 \\
7098 \\
7114 \\
7127 \\
7145\end{array}$ \\
\hline $\begin{array}{l}\text { OU-1085-STRAT4-01 } \\
\text { OU-1085-STRAT4-02 } \\
\text { OU-1085-STRAT4-03 } \\
\text { OU-1085-STRAT4-04 } \\
\text { OU-1085-STRAT4-05 } \\
\text { OU-1085-STRAT4-06 } \\
\text { OU-1085-STRAT4-07 } \\
\text { OU-1085-STRAT4-08 } \\
\text { OU-1085-STRAT4-09 } \\
\text { OU-1085-STRAT4-10 } \\
\text { OU-1085-STRAT4-11 } \\
\text { OU-1085-STRAT4-12 } \\
\text { OU-1085-STRAT4-13 } \\
\text { OU-1085-STRAT4-14 }\end{array}$ & $\begin{array}{l}\text { Qbt 2 } \\
\text { Qbt 2 } \\
\text { Qbt 2 } \\
\text { Qbt 2 } \\
\text { Qbt 2 } \\
\text { Qbt 2 } \\
\text { Qbt 2 } \\
\text { Qbt 3(l) } \\
\text { Qbt 3(l) } \\
\text { Qbt 3(u) } \\
\text { Qbt 3(u) } \\
\text { Qbt 3(u) } \\
\text { Qbt 3(u) } \\
\text { Qbt 3(u) }\end{array}$ & $\begin{array}{l}67-1042 \\
67-1043 \\
67-1044 \\
67-1045 \\
67-1046 \\
67-1047 \\
67-1048 \\
67-1049 \\
67-1050 \\
67-1051 \\
67-1052 \\
67-1053 \\
67-1054 \\
67-1055\end{array}$ & $\begin{array}{l}1762792 \\
1762801 \\
1762828 \\
1762874 \\
1762894 \\
1762927 \\
1763032 \\
1763103 \\
1763113 \\
1763139 \\
1763155 \\
1763177 \\
1763194 \\
1763305\end{array}$ & $\begin{array}{l}1630033 \\
1630029 \\
1630043 \\
1630025 \\
1630032 \\
1630045 \\
1630049 \\
1630104 \\
1630156 \\
1630168 \\
1630181 \\
1630199 \\
1630226 \\
1630208\end{array}$ & $\begin{array}{l}6864 \\
6883 \\
6897 \\
6914 \\
6934 \\
6951 \\
6968 \\
6981 \\
7001 \\
7017 \\
7033 \\
7049 \\
7065 \\
7071\end{array}$ \\
\hline $\begin{array}{l}\text { OU-1085-STRAT5-01 } \\
\text { OU-1085-STRAT5-02 } \\
\text { OU-1085-STRAT5-03 } \\
\text { OU-1085-STRAT5-04 } \\
\text { OU-1085-STRAT5-05 } \\
\text { OU-1085-STRAT5-06 } \\
\text { OU-1085-STRAT5-07 } \\
\text { OU-1085-STRAT5-08 } \\
\text { OU-1085-STRAT5-09 } \\
\text { OU-1085-STRAT5-10 } \\
\text { OU-1085-STRAT5-11 } \\
\text { OU-1085-STRAT5-12 } \\
\text { OU-1085-STRAT5-13 }\end{array}$ & $\begin{array}{l}\text { Qbt 2 } \\
\text { Qbt 2 } \\
\text { Qbt2 } \\
\text { Qbt 2 } \\
\text { Qbt 2 } \\
\text { Qbt 2 } \\
\text { Qbt 2 } \\
\text { Qbt 3(l) } \\
\text { Qbt 3(u) } \\
\text { Qbt 3(u) } \\
\text { Qbt 3(u) } \\
\text { Qbt 3(u) } \\
\text { Qbt 3(u) }\end{array}$ & $\begin{array}{l}67-1056 \\
67-1057 \\
67-1058 \\
67-1059 \\
67-1060 \\
67-1061 \\
67-1062 \\
67-1063 \\
67-1064 \\
67-1065 \\
67-1066 \\
67-1067 \\
67-1068 \\
\end{array}$ & $\begin{array}{l}1764854 \\
1764875 \\
1764894 \\
1764895 \\
1764918 \\
1764943 \\
1764997 \\
1765058 \\
1765124 \\
1765138 \\
1765142 \\
1765168 \\
1765261 \\
\end{array}$ & $\begin{array}{l}1630474 \\
1630463 \\
1630458 \\
1630469 \\
1630474 \\
1630457 \\
1630499 \\
1630567 \\
1630589 \\
1630592 \\
1630611 \\
1630611 \\
1630650\end{array}$ & $\begin{array}{l}6891 \\
6905 \\
6922 \\
6938 \\
6955 \\
6970 \\
6988 \\
7005 \\
6988 \\
7037 \\
7054 \\
7067 \\
7088\end{array}$ \\
\hline
\end{tabular}

\footnotetext{
1 Locations listed as NAD83 State Plane Coordinates. Sample locations surveyed by Merrick and Co., 1994.

2 Strat. Unit - Qbt $2=$ Tshirege unit 2; Qbt $3(l)=$ Tshirege unit 3, lower part; Qbt $3(u)=$ Tshirege unit 3, upper part; Qbt $4=$ Tshirege unit 4 .

${ }^{3}$ Location estimated from adjacent surveyed samples and from jacob staff traverse.
} 
Procedure), and LANL-EES-DP-116 (Quantitative X-Ray Diffraction Data Reduction Procedure). Yucca Mountain Project quality assurance requirements are comparable in rigor to those used by the Los Alamos Environmental Restoration Program.

Thin-section modal point counts were made on 14 samples from stratigraphic section STRAT-2. At least 2465 points were counted for each thin section. The point counts tallied percentages of phenocrysts, lithic fragments, pumice, shards, and voids following the draft procedure LANL-ER-SOP-03.05 (Determination of Volume Constituents in Thin Sections of Rock). Thin sections were prepared according to Yucca Mountain Project procedure LANL-EES-DP-130 (Geologic Sample Preparation). Opaque oxide minerals were qualitatively identified using criteria outlined in Yucca Mountain procedure TWS-ESS-DP-128 (Procedure for Counting Opaque Minerals in Polished Thin Sections). Additional petrographic observations of textures, alteration features, and accessory minerals were collected using procedure LANL-ER-SOP-03.04 (Petrography).

\section{RESULTS AND DISCUSSION}

\section{Stratigraphy and Lithology}

The Bandelier Tuff is divided into two genetically related members, each with a basal pumice fall overlain by a petrologically related succession of ash flows (Griggs, 1964, Bailey et al., 1969, Smith et al., 1970). The lower member, designated the Otowi Member, was erupted at $1.613 \pm$ $0.011 \mathrm{Ma}$ (Izett and Obradovich, 1994) from a caldera source coincident with the younger Valles caldera (Goff et al., 1984; Self et al., 1986). The Otowi Member does not crop out at Pajarito Mesa, but most likely it is present in the subsurface. The upper Bandelier Tuff, designated the Tshirege Member, was erupted from the Valles caldera (Smith and Bailey, 1966; Smith et al., 1970 ) at $1.223 \pm 0.018 \mathrm{Ma}$ (Izett and Obradovich, 1994). The Tshirege Member is divided into informal units based on vertical variations in welding and crystallization (Broxton and Reneau, 1995). Upper units of the Tshirege Member (Qbt 4, Qbt 3, and Qbt 2) crop out at Pajarito Mesa and in adjacent canyons. Lower units of the Tshirege Member (Qbt 1V, Qbt 1g, and Tsankawi Pumice Bed) occur below the level of the canyon floors. Tephras and volcaniclastic sediments of the Cerro Toledo interval are present between the two members of the Bandelier Tuff at many locations on the Pajarito Plateau (Broxton et al., 1995; Broxton and Reneau, 1995); if present, these deposits occur in the subsurface at Pajarito Mesa.

The exposed thickness of the Tshirege Member at Pajarito Mesa is as much as $73 \mathrm{~m}$, but the base of the unit is not exposed. Assuming a thickness similar to that at drill hole SHB-1 $1.8 \mathrm{~km}$ north of PS-1 at TA-55 (Gardner et al., 1993), the Tshirege Member may be about $90 \mathrm{~m}$ thick in the vicinity of Pajarito Mesa.

\section{Tshirege Unit 2}

Tshirege unit 2 (Qbt 2) is the lowermost unit of the Tshirege Member exposed at Pajarito Mesa. It is a vertical, cliff-forming unit that crops out at the bottom of Pajarito Canyon and in the incised inner gorge in the eastern part of Threemile Canyon. The base of Qbt 2 is exposed at the eastern end of Pajarito Mesa in Threemile Canyon, where the unit is about $32 \mathrm{~m}$ thick. This thickness agrees well with the thickness of about $35 \mathrm{~m}$ determined for this unit in drill hole SHB-1 at TA-55 (Gardner et al., 1993). Cliff faces weather to a distinctive, medium-brown color that stand out in marked contrast to the less resistant, lighter-colored tuffs above.

$\mathrm{Qbt} 2$ is a massive, well-indurated, vapor-phase altered ignimbrite. The tuffs in this unit are poorly-sorted and consist of relatively sparse crystal-rich pumice lapilli ( $2 \%$ to $15 \%$ of the tuff) supported by an ashy matrix of shards, pumice fragments, and abundant phenocrysts (Fig. 2a). 
Qbt 2 is moderately to densely welded throughout the study area and has pumice aspect ratios of $3: 1$ to 10:1. It is significantly more welded at Pajarito Mesa than at more distal exposures of the Tshirege Member such as those at TA-21 (Broxton et al., 1995). Because of their high degree of welding, vertical outcrops of these hard tuffs stand out in marked contrast to overlying units, including the Qbt 3 caprock. Because of the degree of compaction of these tuffs, they are likely to have significantly less matrix permeability than overlying units. However, Qbt 2 is more fractured than other units, and water and vapor flow through fractures is possible.

Devitrification and vapor-phase crystallization destroyed most of the original vitroclastic textures in Qbt 2. Relict shards with axiolitic textures occur in a cryptocrystalline to microcrystalline groundmass. Pumices were particularly susceptible to vapor-phase alteration and typically have
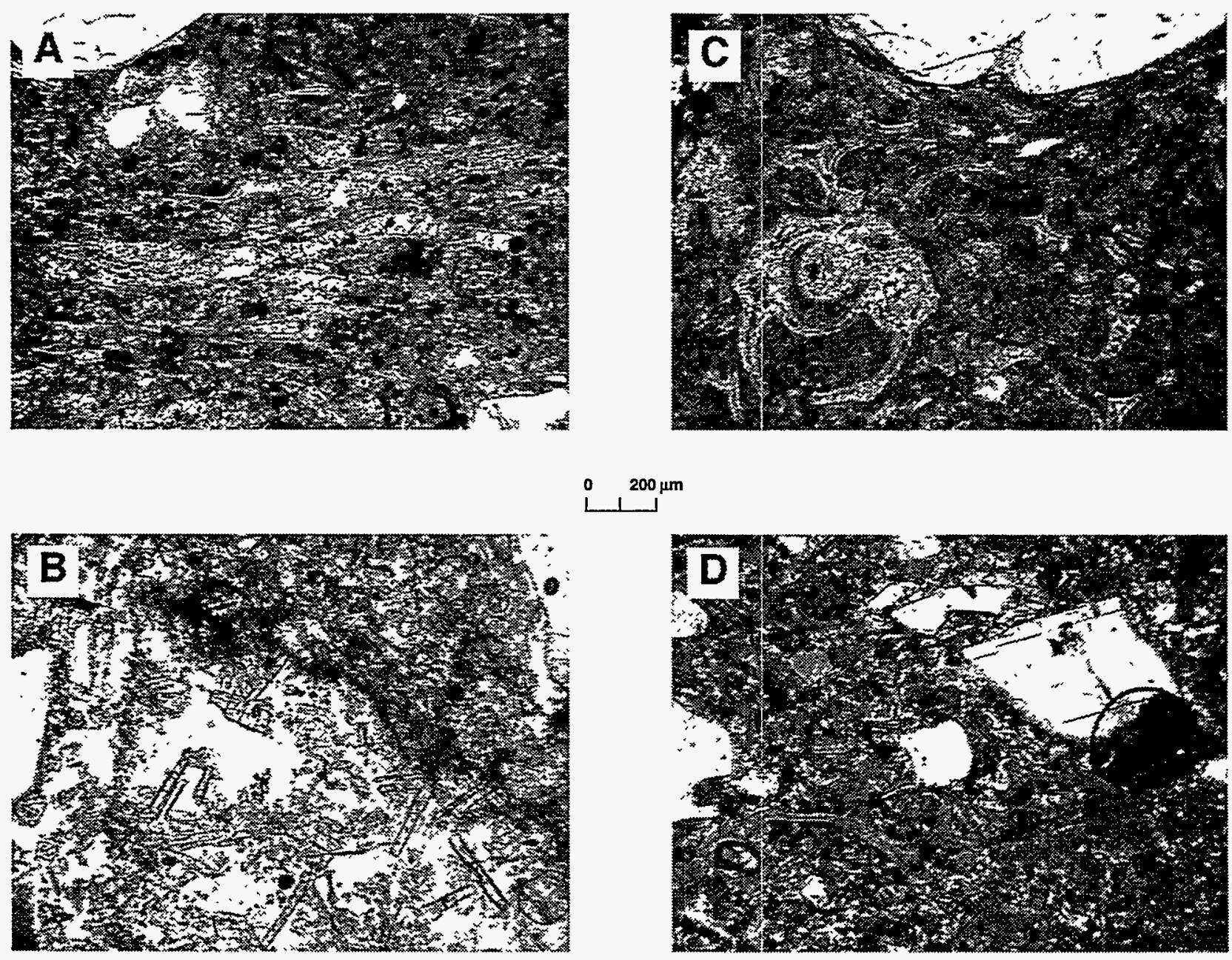

Fig. 2. Photomicrographs of thin sections from representative samples of the Tshirege Member at Pajarito Mesa. All photographs are at the same scale. a) Moderately-welded ignimbrite of Qbt 2 with compaction of shards and pumice pyroclasts giving the tuff a well defined foliation. The matrix has low porosity and is probably relatively impermeable. b) Nonwelded tuffs of Qbt (l). These tuffs are highly porous and represent a marked change in hydrologic properties when compared to Qbt 2. Note the deposition of rod-like tridymite crystals in open pores as a result of vapor-phase alteration. c) Nonwelded to partially-welded ignimbrite of Qbt $3(u)$. These tuffs are poorly compacted, but have a greater degree of induration than Qbt 3(l). d) Nonwelded ignimbrite of Qbt 4. The emplacement of these shardy tuffs represented a distinctive shift toward less silicic magma compositions during the eruption of the Tshirege Member. 
a granophyric texture in thin section. Hand specimens of pumice appear sugary in texture due to the deposition of medium-grained (up to $0.3 \mathrm{~mm}$ ) crystals of tridymite and sanidine.

Phenocrysts make up 23 to $35 \%$ of the rock on a vold-free basis (Table 2). Sanidine and quartz make up over $95 \%$ of the phenocrysts present. The maximum size of these phenocrysts is $4 \mathrm{~mm}$. Clinopyroxene and fayalite are the dominant ferromagnesian minerals, and magnetite, zircon, and perrierite/chevkinite are accessory minerals. Hornblende is also present in these tuffs; the hornblende is derived from the disaggregation of cognate hornblende-bearing dacitic pumices which are common $(<5 \%)$ in these rocks.

Lithic clasts are rare $(<1 \%)$ and are mostly devitrified rhyolite. Most lithics are less than 3 $\mathrm{cm}$ in diameter.

Well-developed fractures are characteristic of Qbt 2. Most fractures are nearly vertical although some horizontal and low-angle fractures are also present. At PS-2 and PS-3, some of the horizontal fractures can be traced laterally for tens of meters and may represent depositional boundaries. Additional more detailed information about fractures is given in the accompanying report by Vaniman and Chipera.

\section{Tshirege Unit 3}

Unit 3 of the Tshirege Member (Qbt 3 ) is divided into lower and upper subunits (Qbt $3(I)$ and $\mathrm{Qbt} 3(\mathrm{U})$, respectively) based on differences in lithological and erosional characteristics. $\mathrm{Qbt} 3(\mathrm{I})$ is made up of $8 \mathrm{~m}$ to $12 \mathrm{~m}$ of nonwelded ignimbrite that underlies the upper part of the broad, gentlysloping bench developed on top of $\mathrm{Qbt} 2$. Qbt 3(u) is a prominent cliff-forming ignimbrite that forms the caprock of Pajarito Mesa. Qbt $3(\mathrm{u})$ is $30 \mathrm{~m}$ thick at PS-1, and thins to about $24 \mathrm{~m}$ at PS3 where its top is eroded. The contact between the $\mathrm{Qbt} 3(\mathrm{l})$ and $\mathrm{Qbt} 3(\mathrm{u})$ is gradational over a meter and is arbitrarily defined as the break in slope at the base of Qbt 3(l).

$\mathrm{Qbt} 3(\mathrm{I})$ is a soft white ignimbrite that typically weathers into low, rounded outcrops. Pumices are sparse $(<5 \%)$ and have a sugary texture due to vapor-phase alteration. $Q b t 3(l)$ is non-indurated and highly porous. Typically, exposures of $\mathrm{Qbt} 3(\mathrm{l})$ are poor because most outcrops are covered by talus derived from the $\mathrm{Qbt} 3(\mathrm{u})$ caprock. The contact between $\mathrm{Qbt} 3(\mathrm{l})$ and $\mathrm{Qbt} 2$ represents an abrupt change in welding characteristics. Although largely covered by talus, this contact occurs within less than a meter of vertical section, and it represents a well-developed partial cooling break in the Tshirege Member. Although covered, the abrupt change in welding at this contact suggests a significant hiatus in the eruption of the Tshirege Member, indicating that the boundary is probably depositional in nature.

The contact between $\mathrm{Qbt} 3(\mathrm{I})$ and $\mathrm{Qbt} 2$ may be a significant hydrologic boundary because of vertical differences in the matrix properties of the tuff. Although testing of hydrologic properties of tuffs has not yet occurred at Pajarito Mesa, $\mathrm{Qbt} 3(\mathrm{I})$ is expected to have significantly higher porosities and permeabilities than unit 2 because of its lesser degree of compaction (Fig. $2 b$ ). Because of the probable contrast of hydrologic properties of the tuff matrix, this contact may act as a zone of accumulation for downward moving ground water. If enough moisture accumulates, ground water may be diverted laterally and move in a down dip direction until it daylights on canyon walls.

Qbt 3(u) is a massive, nonwelded to moderately welded, pumice-poor, vapor-phase altered ignimbrite. The tuff contains 5 to $15 \%$ crystal-rich pumice lapilli in an ashy matrix made up of shards, pumice fragments, and abundant phenocrysts (Fig. 2c). The lower part of the unit is nonwelded and relatively soft. These nonwelded tuffs grade upwards into hard, well-indurated, partially to moderately welded tuffs near the top of the cliff. Although a cliff-former, Qbt $3(u)$ is significantly less resistant than Qbt 2 and tends to form less-steep outcrops. The degree of welding in the upper part of $\mathrm{Qbt} 3(\mathrm{u})$ is greatest in the western part of the study area and decreases eastward. A similar west to east decrease in welding was noted for Qbt 3(u) at TA-21 (Broxton et 
Table 2. Modal Petrography of Tuffs at Pajarito Mesa, Los Alamos, NM

\begin{tabular}{|c|c|c|c|c|c|c|c|c|c|c|}
\hline \multirow[b]{2}{*}{$\begin{array}{l}\text { Field Number } \\
\text { Stratigraphic Unit } \\
\text { Lithology }^{2}\end{array}$} & \multicolumn{10}{|c|}{ Stratigraphic Section 2} \\
\hline & $\begin{array}{l}1085-2-1 \\
\text { Qbt } 2 \\
\text { mwt-dwt }\end{array}$ & $\begin{array}{l}\text { 1085-2-2 } \\
\text { Qbt 2 } \\
\text { mwt }\end{array}$ & $\begin{array}{l}1085-2-3 \\
\text { Qbt 2 } \\
\text { mwt }\end{array}$ & $\begin{array}{l}1085-2-4 \\
\text { Qbt2 } \\
\text { mwt }\end{array}$ & $\begin{array}{l}1085-2-5 \\
\text { Obt 2 } \\
\text { mwt }\end{array}$ & $\begin{array}{c}1085-2-6 \\
\text { Qbt 2 } \\
\text { mwt }\end{array}$ & $\begin{array}{l}1085-2-7 \\
\text { Qbt 3(l) } \\
\text { nwt }\end{array}$ & $\begin{array}{l}1085-2-8 \\
\text { Qbt 3(u) } \\
\text { nwt }\end{array}$ & $\begin{array}{l}1085-2-9 \\
\text { Qbt 3(u) } \\
\text { nwt }\end{array}$ & $\begin{array}{l}1085-2-10 \\
\text { Qbt 3(u) } \\
\text { nwt-pwt }\end{array}$ \\
\hline $\begin{array}{l}\text { Major Alteration } \\
\text { Minor Alteration } \\
\text { M }\end{array}$ & $\underset{\text { VP }}{D}$ & $\underline{D, V P}$ & D, vP & D, VP & D, vP & D, VP & D, VP & D, VP & $\underline{D}, \underline{-}$ & $\underline{D}, V P$ \\
\hline \multicolumn{11}{|l|}{ Matrix Materials (volume $\%)^{4}$} \\
\hline $\begin{array}{l}\text { Ash, shards, pumice } \\
\text { Lithics (silicic volcanics) } \\
\text { Lithics (intermediate lavas) } \\
\text { Lithics (other) } \\
\text { mafic fine-grain inclusions }\end{array}$ & $\begin{array}{l}67.5 \\
0.2 \\
0.1 \\
0.7 \\
-\end{array}$ & $\begin{array}{l}71.6 \\
\overline{0} \\
-1\end{array}$ & $\begin{array}{l}68.3 \\
0.6 \\
1.4 \\
= \\
-\end{array}$ & $\begin{array}{l}65.1 \\
0.5 \\
=\end{array}$ & $\begin{array}{l}73.3 \\
0.3 \\
= \\
=\end{array}$ & $\begin{array}{l}69.9 \\
0.1 \\
0.1 \\
=\end{array}$ & $\begin{array}{l}62.0 \\
1.0 \\
0.1 \\
=\end{array}$ & $\begin{array}{l}60.8 \\
1.2 \\
1.7 \\
-\end{array}$ & $\begin{array}{l}69.8 \\
0.6 \\
0.7 \\
= \\
-\end{array}$ & $\begin{array}{l}74.1 \\
0.3 \\
0.9 \\
=\end{array}$ \\
\hline \multicolumn{11}{|l|}{ Phenocrysis (vol, \%) ${ }^{4}$} \\
\hline $\begin{array}{l}\text { Quartz } \\
\text { Alkali Feldspar } \\
\text { Plagloclase } \\
\text { Biotite }\end{array}$ & $\begin{array}{l}14.4 \\
16.6 \\
0.1(4) \\
0(2)\end{array}$ & $\begin{array}{l}10.4 \\
17.0 \\
0.2(5) \\
0(2)\end{array}$ & $\begin{array}{l}12.2 \\
16.7 \\
0(1)\end{array}$ & $\begin{array}{l}14.7 \\
19.4 \\
0.3(7) \\
-\end{array}$ & $\begin{array}{l}8.5 \\
17.7 \\
0(2) \\
-0(7)\end{array}$ & $\begin{array}{l}12.9 \\
16.3 \\
0.2(5) \\
0(1)\end{array}$ & $\begin{array}{l}18.8 \\
17.7 \\
-\end{array}$ & $\begin{array}{l}14.5 \\
21.5 \\
0.1(2) \\
0(1)\end{array}$ & $\begin{array}{l}13.9 \\
14.6 \\
0.04(2) \\
\frac{0}{0(2)}\end{array}$ & $\begin{array}{l}5.6 \\
18.6 \\
0.1(2) \\
0.04(7)\end{array}$ \\
\hline Homblende & $0.1(8)$ & 0.2 & $0(3)$ & $\underline{0(2)}$ & $0(7)$ & $0(2)$ & $\underline{0(3)}$ & $0(2)$ & $0(2)$ & $0.04(7)$ \\
\hline $\begin{array}{l}\text { Orthopyroxene } \\
\text { Clinopyroxene }\end{array}$ & $0.2(9)$ & $\overline{0.4}$ & 二 & - & 二 & $=$ & $\overline{0.3}$ & $\overline{0.3}$ & $\overline{0.2}$ & $\overline{0.2}$ \\
\hline Fayalite & - & - & 0.2 & - & $0.04(1)$ & - & - & - & - & - \\
\hline Other (Pseudomorphs etc.) & - & - & 0.5 & 0.04 & & 0.3 & - & - & - & - \\
\hline \multicolumn{11}{|l|}{ Accessony Minerals (counts) ${ }^{4}$} \\
\hline $\begin{array}{l}\text { Fe-Ti Oxides } \\
\text { Perrierite/Chevkinite }\end{array}$ & $\begin{array}{l}0.2(48) \\
0(1)\end{array}$ & $\begin{array}{l}0.2(35) \\
0(1)\end{array}$ & $\begin{array}{l}0.1(33) \\
0(2)\end{array}$ & $\begin{array}{l}0.1(37) \\
0(1)\end{array}$ & $\begin{array}{l}0.1(37) \\
0(5)\end{array}$ & $\begin{array}{l}0.1(39) \\
0(2)\end{array}$ & $\begin{array}{l}0.2(23) \\
0(1)\end{array}$ & $\begin{array}{l}0.1(34) \\
0(1)\end{array}$ & $\begin{array}{l}0.2(33) \\
0(2)\end{array}$ & $\begin{array}{l}0.04(53) \\
0(1)\end{array}$ \\
\hline Monazite & - & $O(1)$ & - & $0(1)$ & - & - & & $o(1)$ & - & \\
\hline Zircon & $0(2)$ & - & $0(9)$ & $0(11)$ & $0(11)$ & $0(5)$ & $0(4)$ & $0(3)$ & $0(3)$ & $0(2)$ \\
\hline $\begin{array}{l}\text { Apatite } \\
\text { Sphene }\end{array}$ & $=$ & 二 & $\overline{-}$ & 二 & $\overline{-}$ & $=$ & $\overline{0}(14)$ & $\overline{-}$ & 二 & $\bar{Z}$ \\
\hline $\begin{array}{l}\text { Total Counts } \\
\text { Pumice and Voids (counts) }\end{array}$ & $\begin{array}{l}3049 \\
502\end{array}$ & $\begin{array}{l}2945 \\
399\end{array}$ & $\begin{array}{l}2773 \\
385\end{array}$ & $\begin{array}{l}2969 \\
288\end{array}$ & $\begin{array}{l}3015 \\
412\end{array}$ & $\begin{array}{l}3047 \\
329\end{array}$ & $\begin{array}{l}2671 \\
824\end{array}$ & $\begin{array}{l}2523 \\
725\end{array}$ & $\begin{array}{l}2900 \\
405\end{array}$ & $\begin{array}{l}2858 \\
470\end{array}$ \\
\hline Remarks & $\begin{array}{l}\text { Magnetite w/ } \\
\text { limenite } \\
\text { lamella and } \\
\text { thin hematite } \\
\text { rims }\end{array}$ & $\begin{array}{l}\text { Magnetite w/ } \\
\text { ilmenite } \\
\text { lamella and } \\
\text { thin hematite } \\
\text { rims }\end{array}$ & $\begin{array}{l}\text { Magnetite wl } \\
\text { filmenite } \\
\text { lamella and } \\
\text { thin hematite } \\
\text { rims }\end{array}$ & $\begin{array}{l}\text { Magnetite w/ } \\
\text { ilmenlte } \\
\text { lamella and } \\
\text { thin hematite } \\
\text { rims }\end{array}$ & $\begin{array}{l}\text { Magnetite w/ } \\
\text { ilmenite } \\
\text { lamella and } \\
\text { trace } \\
\text { hematite }\end{array}$ & $\begin{array}{l}\text { Magnetite w/ } \\
\text { Ilmenite } \\
\text { lamelia and } \\
\text { trace } \\
\text { hematite }\end{array}$ & $\begin{array}{l}\text { Magnetite w/ } \\
\text { Ilmenite lamella } \\
\text { and trace } \\
\text { hematite. Alkall } \\
\text { feldspar } \\
\text { overgrowths }\end{array}$ & $\begin{array}{l}\text { Magnetite w/ } \\
\text { ilmenite lamella } \\
\text { and trace } \\
\text { hematite. Alkall } \\
\text { feldspar } \\
\text { overgrowths }\end{array}$ & $\begin{array}{l}\text { Magnetite w/ } \\
\text { llmenite lamella } \\
\text { and trace } \\
\text { hematite. Alkall } \\
\text { feldspar } \\
\text { overgrowths }\end{array}$ & $\begin{array}{l}\text { Magnetite w/ } \\
\text { ilmenite lamella } \\
\text { and trace } \\
\text { hematite Alkall } \\
\text { leldspar. } \\
\text { overgrowths }\end{array}$ \\
\hline $\begin{array}{l}\text { Phenocryst Summary } \\
\text { \% Phenocrysts (Vold-free) }\end{array}$ & 31.5 & 28.4 & 29.7 & 34.5 & 26.5 & 29.8 & 36.9 & 30.8 & 33.1 & 24.7 \\
\hline $\begin{array}{l}\text { Quartz as \% of Felsic Phenos. } \\
\text { Sanidine as \% of Felsic Phenos. } \\
\text { Plagioclase as \% of Felsic Phenos. }\end{array}$ & $\begin{array}{l}46 \\
53 \\
0\end{array}$ & $\begin{array}{l}38 \\
62 \\
1\end{array}$ & $\begin{array}{l}42 \\
58 \\
0\end{array}$ & $\begin{array}{l}43 \\
56 \\
1\end{array}$ & $\begin{array}{l}32 \\
68 \\
0\end{array}$ & $\begin{array}{l}44 \\
56 \\
1\end{array}$ & $\begin{array}{l}51 \\
49 \\
0\end{array}$ & $\begin{array}{l}48 \\
52 \\
0\end{array}$ & $\begin{array}{l}49 \\
51 \\
1\end{array}$ & $\begin{array}{l}23 \\
76 \\
1\end{array}$ \\
\hline $\begin{array}{l}\text { \% Mafic Phenocrysts } \\
\% \text { Lithics }\end{array}$ & $\begin{array}{l}0.3 \\
1.0\end{array}$ & $\begin{array}{l}0.6 \\
0.1 \\
\end{array}$ & $\begin{array}{l}0.8 \\
2.0 \\
\end{array}$ & $\begin{array}{l}0.1 \\
0.5 \\
\end{array}$ & $\begin{array}{l}0.3 \\
0.3\end{array}$ & $\begin{array}{l}0.4 \\
0.3\end{array}$ & $\begin{array}{l}0.4 \\
1.0\end{array}$ & $\begin{array}{l}0.3 \\
2.8\end{array}$ & $\begin{array}{l}0.4 \\
1.5 \\
\end{array}$ & $\begin{array}{l}0.3 \\
1.2 \\
\end{array}$ \\
\hline
\end{tabular}

${ }^{1}$ Strat. Unit - Qbt $2=$ Tshirege unit 2; Qbt $3(l)=$ Tshirege unit 3, lower part; Qbt $3(u)=$ Tshirege unit 3, upper part; Qbt 4 = Tshirege unit 4.

${ }^{2}$ Lithology $-n w t=$ nonwelded ash-flow tuff; pwt $=$ partly welded ash-flow tuff, mwt $=$ moderately welded ash-flow tuff; dwt $=$ densely welded ash-flow tuff.

${ }^{3}$ Alteration - $D=$ high temperature devitrification; $V P=$ vapor-phase crystallization.

- Matrix minerals, phenocrysts, and accessory minerals are presented as volume percent concentrations on a void-free basis. Numbers in parentheses are visual counts of lowabundance minerals observed in a thin section. 
Table 2. Modal Petrography of Tuffs at Pajartto Mesa, Los Alamos, NM (cont.)

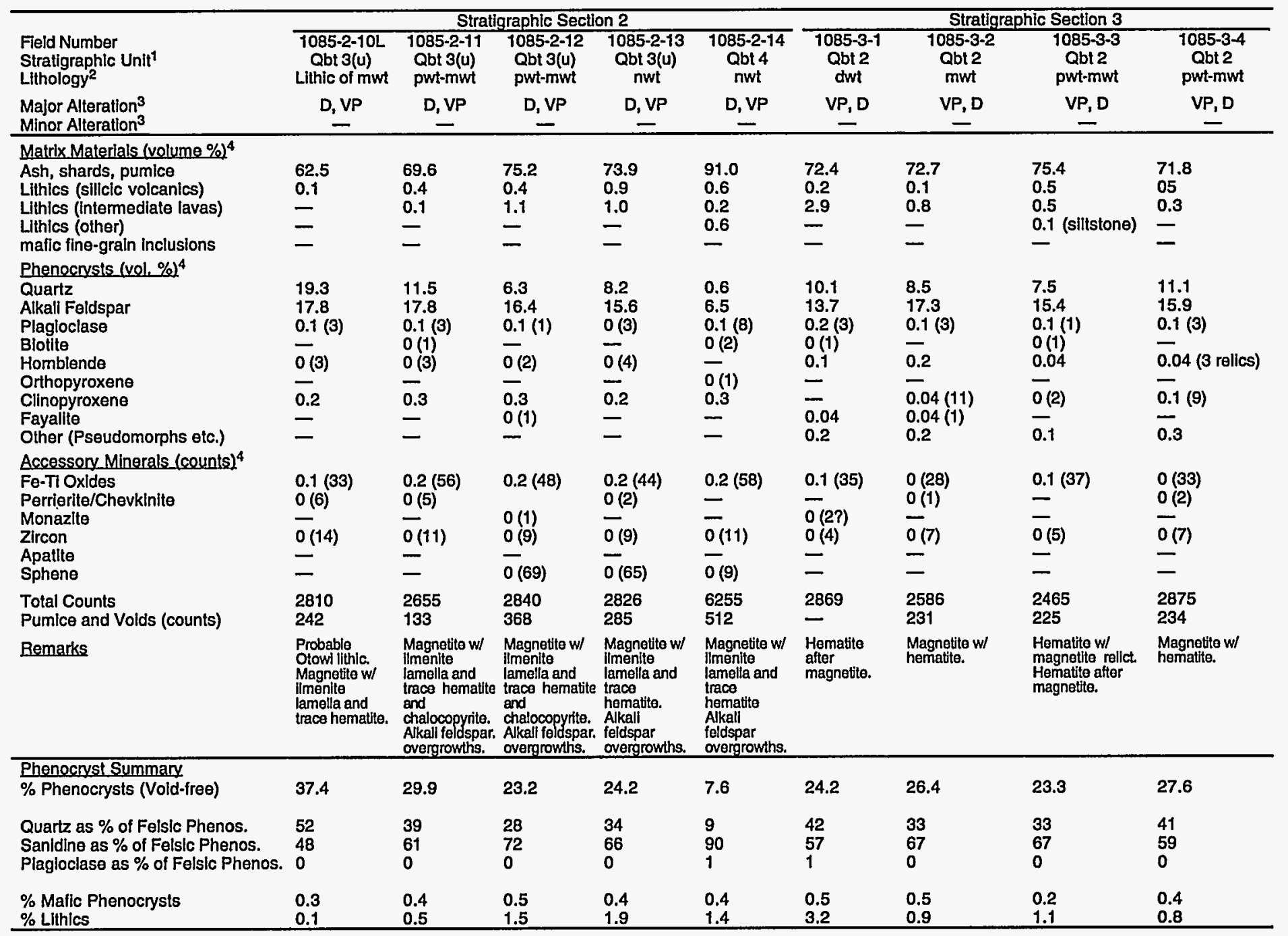

${ }^{1}$ Strat. Unit $-Q b t 2=$ Tshirege unit 2; Qbt $3(l)=$ Tshirege unit 3, lower part; Qbt $3(u)=$ Tshirege unit 3, upper part; Qbt $4=$ Tshirege unit 4.

${ }^{2}$ Lithology - nwt $=$ nonwelded ash-flow tuff; pwt $=$ partly welded ash-flow tuff, mwt = moderately welded ash-flow tuff; dwt = densely welded ash-flow tuff.

${ }^{3}$ Alteration - $D=$ high temperature devitrification; VP = vapor-phase crystallization.

1 Matrix minerals, phenocrysts, and accessory minerals are presented as volume percent concentrations on a void-free basis. Numbers in parentheses are visual counts of lowabundance minerals observed in a thin section. 
Table 2. Modal Petrography of Tuffs at Pajarito Mesa, los Alamos, NM (cont.)

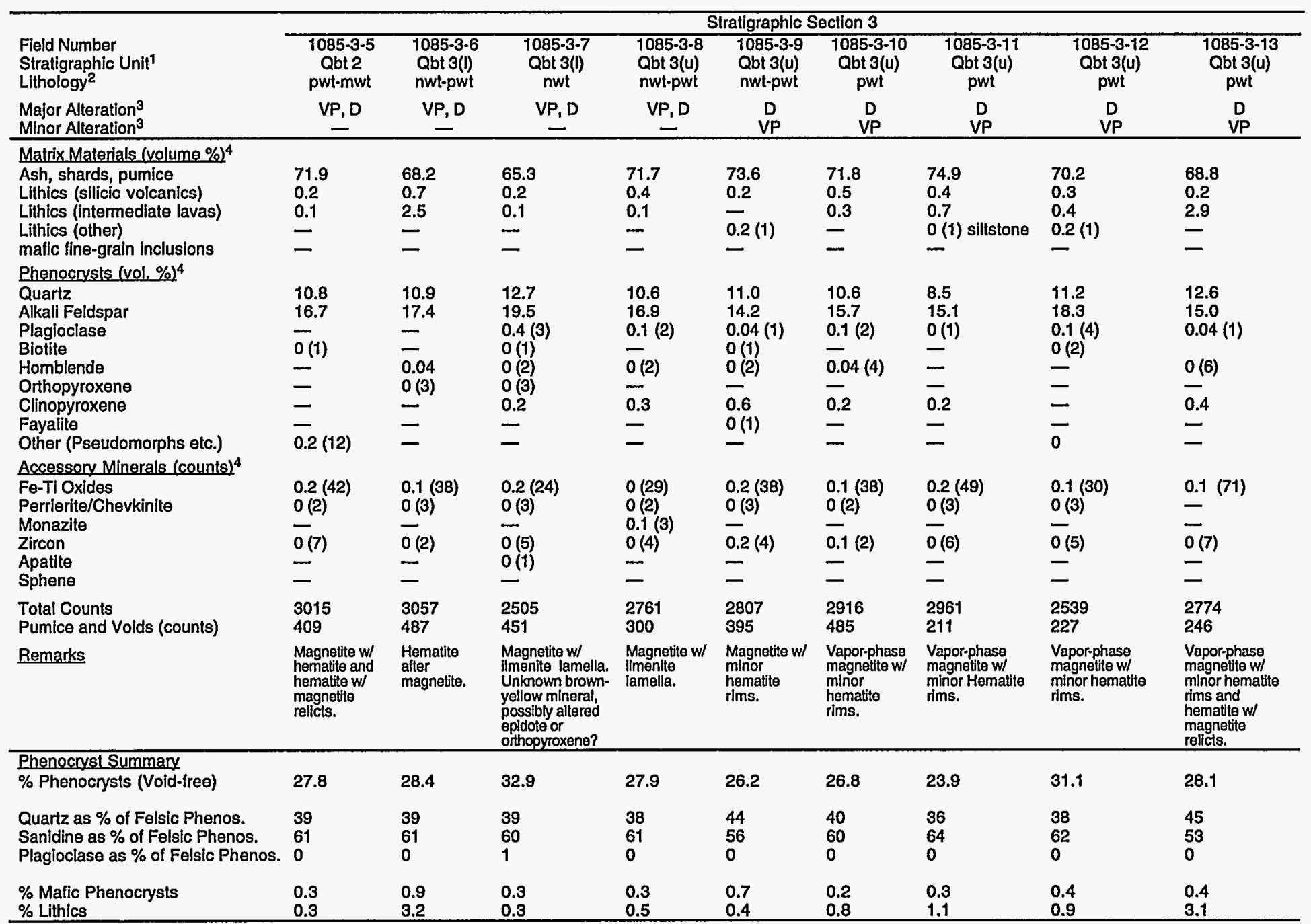

${ }^{1}$ Strat. Unit $-Q b t 2=$ Tshirege unit 2; Qbt $3(l)=$ Tshirege unit 3, lower part Qbt $3(u)=$ Tshirege unit 3, upper part; Qbt $4=$ Tshirege unit 4.

${ }^{2}$ Lithology - nwt $=$ nonwelded ash-flow tuff; pwt = partly welded ash-flow tuff, mwt = moderately welded ash-flow tuff; dwt = densely welded ash-flow tuff ${ }^{3}$ Alteration - $D=$ high temperature devitrification; VP = vapor-phase crystallization.

1 Matrix minerals, phenocrysts, and accessory minerals are presented as volume percent concentrations on a void-free basis. Numbers in parentheses are visual counts of lowabundance minerals observed in a thin section. 
al., 1995), but the overall degree of welding is greater at Pajarito Mesa. The uppermost part of Qbt $3(u)$, exposed on top of Pajarito Mesa, is made up of nonwelded to partially welded tuffs which weather to low, rounded outcrops. Under current plans, the central and eastem parts of the proposed waste disposal cell at PS-1 will be constructed in the upper part of Qbt 3(u).

Because the contact between Qbt $3(\mathrm{l})$ and Qbt 3(u) is gradational and the contrast in lithologic properties is not great, this contact probably does not represent a significant hydrologic boundary for ground water moving by matrix flow. However, $\mathrm{Qbt} 3(\mathrm{u})$ tuffs are more fractured than those of $\mathrm{Qbt} 3(\mathrm{l})$, and fracture flow characteristics may not be similar for the two units. Vaniman and Chipera (this report) found that evaporite minerals occur in fractures of $\mathrm{Qbt} 3(\mathrm{u})$, suggesting a possible lateral component of ground water flow through these fractures.

The phenocryst assemblages and abundances are similar for Qbt $3(l)$ and $\mathrm{Qbt} 3(\mathrm{u})$. Phenocrysts make up $23 \%$ to $37 \%$ of these tuffs on a void-free basis (Table 2). Sanidine and quartz are the most abundant phenocrysts and commonly are $2 \mathrm{~mm}$ to $3.5 \mathrm{~mm}$ in diameter. Clinopyroxene is the dominant ferromagnesian mineral; fayalite is absent in these tuffs. Magnetite, zircon, perrierite/chevkinite are accessory minerals. Hornblende (derived from hornblende-bearing dacitic pumices) is also present in these tuffs.

Lithic clasts generally make up $<1 \%$ to $5 \%$ of $\mathrm{Qbt} 3(\mathrm{l})$ and $\mathrm{Qbt} 3(\mathrm{u})$. The lithics consist of light gray, phenocryst-poor devitrified rhyolite lavas, dark gray porphyritic intermediate-composition lavas, and moderately to densely welded Otowi (?) ignimbrite. Lithics are typically subangular and equant, and most are less than $4 \mathrm{~cm}$ in diameter.

\section{Tshirege Unit 4}

Tshirege unit 4 (Qbt 4) crops out as a low resistant ridge along the centerline of Pajarito Mesa in the western part of PS-1. Qbt 4 thins eastward, and it is not present at PS-2 and PS-3 where presumably the distal edge of this unit has been removed by erosion. Qbt 4 is about $5 \mathrm{~m}$ thick at PS-1.

Qbt 4 is a distinctive tuff unit that consists of a basal, crystal-rich, pyroclastic surge deposit overlain by a pumice-poor, nonwelded to partially-welded shardy ignimbrite (Fig. $2 d$ ). The surge beds are up to $15 \mathrm{~cm}$ thick, and they are characterized by low-angle planar and cross beds. The surge beds and overlying ignimbrite are vapor-phase altered, but the degree of alteration is less than that found in Qbt $3(\mathrm{u})$. The ignimbrite is characterized by small, sparse pumices $(<5 \%)$, a feature that can be used to easily distinguish this unit from the underlying pumice-rich units. Overall, the unit has a sandy appearance.

Phenocrysts comprise about $8 \%$ of the ignimbrite, making unit 4 crystal-poor relative to the underlying units of the Tshirege Member (Table 2). Phenocrysts include those minerals found in underlying units as well as small amounts of hyperstene and anorthoclase. Alkali feldspar to quartz ratios are significantly greater than in underlying units. The surge deposit is a zone of crystal accumulation and contains as much as $50 \%$ phenocrysts. Lithic fragments are extremely rare in unit 4. They consist of light-gray rhyolitic lavas and dark-gray dacitic (?) lavas. Most are less than $1 \mathrm{~cm}$ in diameter.

\section{Mineralogy}

Table 3 and Figure 3 summarize information about the mineralogy of tuffs at Pajarito Mesa. These X-ray diffraction data show that the bulk-tuff mineralogy of the Tshirege Member at Pajarito Mesa is relatively simple, consisting primarily of alkali feldspar ( $60 \%$ by weight) and of combinations of three silica polymorphs (tridymite, quartz, and cristobalite). Together, these four minerals make up over $95 \%$ of the tuff at Pajarito Mesa. Alkali feldspar and cristobalite occur mainly in the tuff matrix as fine-grained (micron-size), high temperature devitrification products that replaced the 
Table 3. Mineralogy of Tuffs at Pajarito Mesa, Los Alamos, NM ${ }^{1}$

\begin{tabular}{|c|c|c|c|c|c|c|c|c|c|c|c|c|c|}
\hline Sample Fleld Number & Notes & Unit $^{2}$ & Smectite & Tridymite & Quartz & $\begin{array}{c}\text { Cristo- } \\
\text { balite }\end{array}$ & Feldspar & Glass & Magnetite & Mica & Hematite & Other & $\begin{array}{c}\boldsymbol{\Sigma} \\
\text { Crystalline } \\
\text { Phases }\end{array}$ \\
\hline \multicolumn{14}{|l|}{ Stratigraphlc Section 1} \\
\hline $\begin{array}{l}\text { OU-1085-STRAT1-10 } \\
\text { OU-1085-STRAT1-9C } \\
\text { OU-1085-STRAT1-9B } \\
\text { OU-1085-STRAT1-9A } \\
\text { OU-1085-STRAT1-8 } \\
\text { OU-1085-STRAT1-7 } \\
\text { OU-1085-STRAT1-6 } \\
\text { OU-1085-STRAT1-5 } \\
\text { OU-1085-STRAT1-4 } \\
\text { OU-1085-STRAT1-3 } \\
\text { OU-1085-STRAT1-3 } \\
\text { OU-1085-STRAT1-2 } \\
\text { OU-1085-STRAT1-1 }\end{array}$ & $\begin{array}{l}\text { Outer } \\
\text { Core }\end{array}$ & $\begin{array}{l}\text { Qbt 4 } \\
\text { Qbt 4 } \\
\text { Qbt 4 } \\
\text { Qbt 3(u) } \\
\text { Qbt 3(u) } \\
\text { Qbt 3(u) } \\
\text { Qbt 3(u) } \\
\text { Qbt 3(u) } \\
\text { Qbt 3(u) } \\
\text { Qbt 3(u) } \\
\text { Qbt 3(u) } \\
\text { Qbt 3(l) } \\
\text { Qbt 2 }\end{array}$ & $\begin{array}{l}2 \pm 1 \\
5+2 \\
7 \pm 2 \\
\mathrm{Tr} \\
\frac{-}{\mathrm{Tr}} \\
\mathrm{Tr} \\
\mathrm{Tr} \\
\mathrm{Tr} \\
\bar{T} \\
\mathrm{Tr}\end{array}$ & $\begin{array}{r}6 \pm 1 \\
5 \pm 1 \\
4 \pm 1 \\
12 \pm 1 \\
9 \pm 1 \\
13 \pm 1 \\
13 \pm 1 \\
13 \pm 1 \\
12 \pm 1 \\
19 \pm 1 \\
17 \pm 1 \\
20 \pm 2 \\
19 \pm 1\end{array}$ & $\begin{array}{l}10 \pm 1 \\
11 \pm 1 \\
23 \pm 2 \\
16 \pm 1 \\
17 \pm 1 \\
15 \pm 1 \\
19 \pm 1 \\
21 \pm 2 \\
24 \pm 2 \\
23 \pm 2 \\
14 \pm 1 \\
21 \pm 2 \\
18 \pm 1\end{array}$ & $\begin{array}{r}12 \pm 1 \\
12 \pm 2 \\
3 \pm 1 \\
7 \pm 3 \\
13 \pm 1 \\
6 \pm 3 \\
6 \pm 3 \\
5 \pm 2 \\
7 \pm 3 \\
- \\
5 \pm 2 \\
-\end{array}$ & $\begin{array}{l}66 \pm 9 \\
62 \pm 9 \\
66 \pm 9 \\
63 \pm 9 \\
64 \pm 9 \\
61 \pm 9 \\
62 \pm 9 \\
62 \pm 9 \\
61 \pm 9 \\
58 \pm 8 \\
60 \pm 8 \\
59 \pm 8 \\
59 \pm 8\end{array}$ & $\begin{array}{l}\bar{z} \\
\bar{z} \\
\bar{z} \\
\bar{z} \\
\bar{z} \\
=\end{array}$ & $\begin{array}{l}= \\
= \\
= \\
= \\
= \\
= \\
=\end{array}$ & $\begin{array}{l}\text { Tr } \\
\operatorname{Tr} \\
\operatorname{Tr} \\
= \\
\overline{T r} \\
= \\
= \\
\bar{T} \\
\overline{T r} \\
\operatorname{Tr}\end{array}$ & $\begin{array}{l}\operatorname{Tr} \\
= \\
= \\
= \\
= \\
\frac{\operatorname{Tr}}{\bar{T}} \\
\frac{1 \pm 1}{\operatorname{Tr}}\end{array}$ & $\begin{array}{l}= \\
= \\
= \\
= \\
= \\
= \\
=\end{array}$ & $\begin{array}{c}96 \pm 9 \\
95 \pm 9 \\
103 \pm 10 \\
98 \pm 10 \\
103 \pm 9 \\
95 \pm 10 \\
100 \pm 10 \\
101 \pm 9 \\
104 \pm 10 \\
100 \pm 8 \\
96 \pm 8 \\
101 \pm 9 \\
96 \pm 8\end{array}$ \\
\hline \multicolumn{14}{|l|}{ Stratigraphic Section 2} \\
\hline $\begin{array}{l}\text { OU-1085-STRAT2-14 } \\
\text { OU-1085-STRAT2-13 } \\
\text { OU-1085-STRAT2-12 } \\
\text { OU-1085-STRAT2-11 } \\
\text { OU-1085-STRAT2-10 } \\
\text { OU-1085-STRAT2-9 } \\
\text { OU-1085-STRAT2-8 } \\
\text { OU-1085-STRAT2-7 } \\
\text { OU-1085-STRAT2-6 } \\
\text { OU-1085-STRAT2-5 } \\
\text { OU-1085-STRAT2-4 } \\
\text { OU-1085-STRAT2-3 } \\
\text { OU-1085-STRAT2-2 } \\
\text { OU-1085-STRAT2-1 }\end{array}$ & & $\begin{array}{l}\text { Qbt 4 } \\
\text { Qbt 3(u) } \\
\text { Qbt 3(u) } \\
\text { Qbt 3(u) } \\
\text { Qbt 3(u) } \\
\text { Qbt 3(u) } \\
\text { Qbt 3(u) } \\
\text { Qbt 3(l) } \\
\text { Qbt 2 } \\
\text { Qbt 2 } \\
\text { Qbt 2 } \\
\text { Qbt 2 } \\
\text { Qbt 2 } \\
\text { Qbt 2 }\end{array}$ & $\begin{array}{l}3 \pm 1 \\
\mathrm{Tr} \\
\frac{\mathrm{Tr}}{\mathrm{Tr}} \\
\frac{1 \pm 1}{\overline{T r}} \\
\frac{-}{\mathrm{Tr}} \\
\frac{-}{-}\end{array}$ & $\begin{array}{r}8 \pm 1 \\
13 \pm 1 \\
12 \pm 1 \\
13 \pm 1 \\
17 \pm 1 \\
19 \pm 1 \\
21 \pm 2 \\
23 \pm 2 \\
21 \pm 2 \\
21 \pm 2 \\
18 \pm 1 \\
19 \pm 1 \\
19 \pm 1 \\
13 \pm 1\end{array}$ & $\begin{array}{r}6 \pm 1 \\
17 \pm 1 \\
17 \pm 1 \\
14 \pm 1 \\
18 \pm 1 \\
23 \pm 2 \\
19 \pm 1 \\
16 \pm 1 \\
18 \pm 1 \\
15 \pm 1 \\
18 \pm 1 \\
18 \pm 1 \\
17 \pm 1 \\
22 \pm 2\end{array}$ & $\begin{array}{l}14 \pm 1 \\
6 \pm 3 \\
5 \pm 2 \\
7 \pm 3 \\
3 \pm 1 \\
= \\
= \\
= \\
= \\
= \\
=\end{array}$ & $\begin{array}{l}63 \pm 9 \\
66 \pm 9 \\
64 \pm 9 \\
61 \pm 9 \\
60 \pm 8 \\
60 \pm 8 \\
59 \pm 8 \\
61 \pm 9 \\
62 \pm 9 \\
63 \pm 9 \\
61 \pm 9 \\
59 \pm 8 \\
63 \pm 9 \\
61 \pm 9\end{array}$ & $\begin{array}{l}= \\
= \\
= \\
= \\
= \\
= \\
= \\
=\end{array}$ & $\begin{array}{l}= \\
\bar{z} \\
\bar{z} \\
\bar{z} \\
= \\
\bar{z} \\
=\end{array}$ & $\begin{array}{l}\overline{\bar{T}} \\
\overline{\operatorname{Tr}} \\
\overline{-} \\
\overline{\operatorname{Tr}} \\
\overline{\operatorname{Tr}} \\
\overline{-} \\
\overline{-} \\
\overline{\overline{T r}}\end{array}$ & $\begin{array}{l}1 \pm 1 \\
= \\
= \\
= \\
= \\
= \\
= \\
=\end{array}$ & $\begin{array}{c}\overline{-} \\
\overline{-} \\
\text { Calcite-Tr } \\
\text { Hornblende-Tr } \\
= \\
= \\
= \\
=\end{array}$ & $\begin{array}{c}95 \pm 9 \\
102 \pm 10 \\
98 \pm 9 \\
95 \pm 10 \\
98 \pm 8 \\
103 \pm 8 \\
99 \pm 8 \\
100 \pm 9 \\
101 \pm 9 \\
99 \pm 9 \\
97 \pm 9 \\
96 \pm 8 \\
99 \pm 9 \\
96 \pm 9\end{array}$ \\
\hline \multicolumn{14}{|l|}{ Stratigraphic Section 3} \\
\hline $\begin{array}{l}\text { OU-1085-STRAT3-13 } \\
\text { OU-1085-STRAT3-12 } \\
\text { OU-1085-STRAT3-11 } \\
\text { OU-1085-STRAT3-10 } \\
\text { OU-1085-STRAT3-9 } \\
\text { OU-1085-STRAT3-8 } \\
\text { OU-1085-STRAT3-7 } \\
\text { OU-1085-STRAT3-7 } \\
\text { OU-1085-STRAT3-6 } \\
\text { OU-1085-STRAT3-5 } \\
\text { OU-1085-STRAT3-4 } \\
\text { OU-1085-STRAT3-3 } \\
\text { OU-1085-STRAT3-2 } \\
\text { OU-1085-STRAT3-1 }\end{array}$ & $\begin{array}{l}\text { Hard } \\
\text { Soft }\end{array}$ & $\begin{array}{l}\text { Qbt 3(u) } \\
\text { Qbt 3(u) } \\
\text { Qbt 3(u) } \\
\text { Qbt 3(u) } \\
\text { Qbt 3(u) } \\
\text { Qbt 3(u) } \\
\text { Qbt 3(l) } \\
\text { Qbt 3(l) } \\
\text { Qbt 3(l) } \\
\text { Qbt 2 } \\
\text { Qbt 2 } \\
\text { Qbt 2 } \\
\text { Qbt 2 } \\
\text { Qbt 2 }\end{array}$ & $\begin{array}{l}\text { Tr } \\
\overline{-} \\
\operatorname{Tr} \\
\operatorname{Tr} \\
\operatorname{Tr} \\
\operatorname{Tr} \\
\operatorname{Tr} \\
\operatorname{Tr} \\
= \\
= \\
= \\
-\end{array}$ & $\begin{array}{r}13 \pm 1 \\
17 \pm 1 \\
12 \pm 1 \\
12 \pm 1 \\
10 \pm 1 \\
18 \pm 1 \\
5 \pm 1 \\
20 \pm 2 \\
21 \pm 2 \\
22 \pm 2 \\
21 \pm 2 \\
22 \pm 2 \\
23 \pm 2 \\
20 \pm 2\end{array}$ & $\begin{array}{r}14 \pm 1 \\
14 \pm 1 \\
16 \pm 1 \\
17 \pm 1 \\
16 \pm 1 \\
18 \pm 1 \\
1 \pm 1 \\
20 \pm 2 \\
18 \pm 1 \\
15 \pm 1 \\
15 \pm 1 \\
15 \pm 1 \\
14 \pm 1 \\
17 \pm 1\end{array}$ & $\begin{array}{l}7 \pm 3 \\
6 \pm 3 \\
7 \pm 3 \\
6 \pm 2 \\
6 \pm 2 \\
= \\
15 \pm 1 \\
= \\
= \\
= \\
=\end{array}$ & $\begin{array}{l}61 \pm 9 \\
59 \pm 8 \\
59 \pm 8 \\
59 \pm 8 \\
62 \pm 9 \\
61 \pm 9 \\
70 \pm 10 \\
57 \pm 8 \\
58 \pm 8 \\
59 \pm 8 \\
60 \pm 8 \\
58 \pm 8 \\
61 \pm 9 \\
57 \pm 8\end{array}$ & $\begin{array}{l}= \\
= \\
= \\
= \\
= \\
= \\
= \\
-\end{array}$ & $\begin{array}{l}= \\
= \\
= \\
\overline{12 \pm 3} \\
= \\
= \\
= \\
=\end{array}$ & $\begin{array}{l}\bar{z} \\
= \\
\bar{z} \\
\overline{\operatorname{Tr}} \\
\overline{-} \\
\bar{z} \\
= \\
=\end{array}$ & $\begin{array}{l}1 \pm 1 \\
= \\
= \\
\overline{T r} \\
= \\
= \\
= \\
= \\
\overline{T r}\end{array}$ & $\begin{array}{c}= \\
= \\
= \\
\text { Calcite } 2 \pm 1 \\
= \\
= \\
= \\
= \\
=\end{array}$ & $\begin{array}{c}96 \pm 10 \\
96 \pm 9 \\
94 \pm 9 \\
94 \pm 8 \\
94 \pm 9 \\
97 \pm 9 \\
105 \pm 11 \\
97 \pm 8 \\
97 \pm 8 \\
96 \pm 8 \\
96 \pm 8 \\
95 \pm 8 \\
98 \pm 9 \\
94 \pm 8\end{array}$ \\
\hline
\end{tabular}

${ }^{1}$ Mineral identifications and abundances determined by $X$-ray diffraction; mineral abundances reported as weight percent; uncertainties are two standard deviation estimates of analytical precision; - indicates mineral not detected; $T r=$ trace abundance $(<0.5 w t . \%)$.

${ }^{2}$ Strat. Unit - Qbt $2=$ Tshirege unit 2; Qbt $3(l)=$ Tshirege unit 3, lower part; Qbt 3(u)=Tshirege unit 3, upper part; Qbt 4=Tshirege unit 4. 


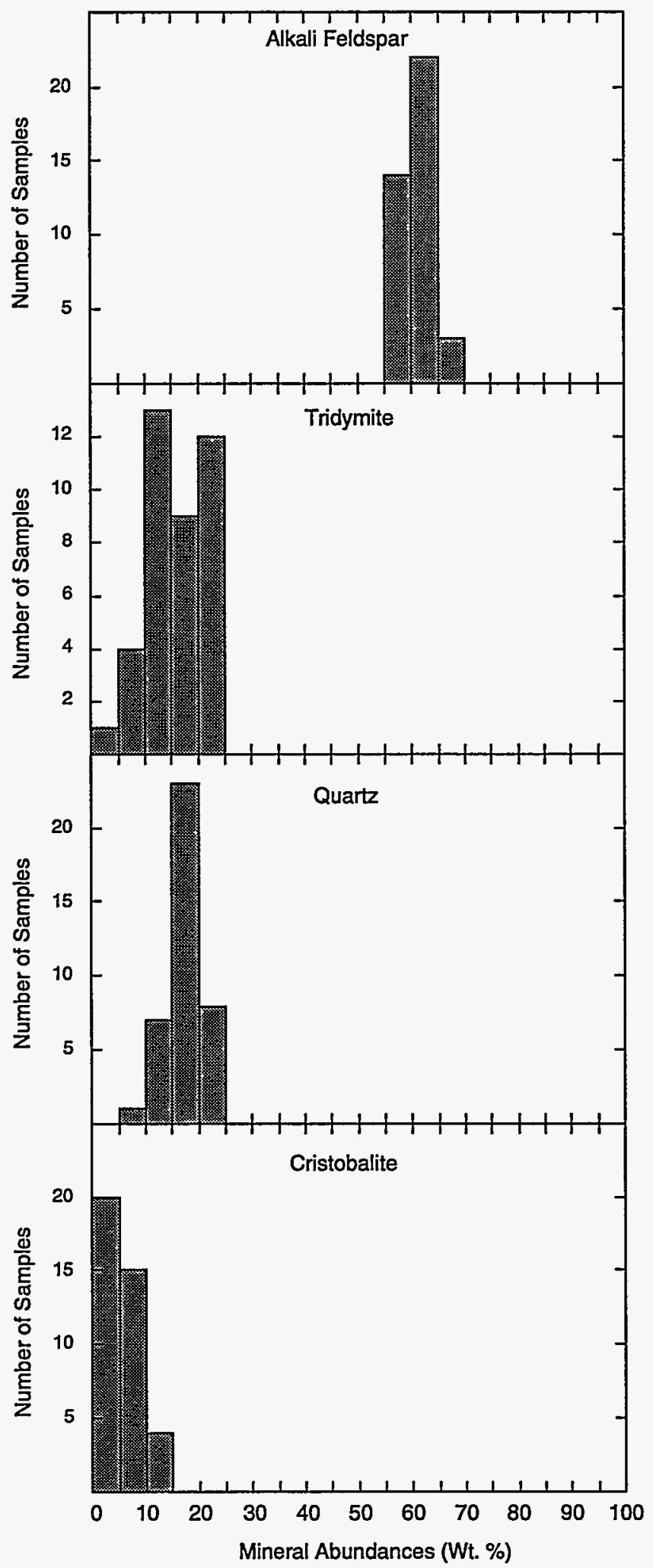

Fig. 3. Histogram showing the abundances of the principal minerals making up the tuffs at Pajarito Mesa. 
original volcanic glass following emplacement during cooling of the tuff. The tridymite and some alkali feldspar were deposited in open pore spaces by vapors released during outgassing of the tuff after emplacement. Between $50 \%$ and $100 \%$ of the quartz and about $25 \%$ of the alkali feldspar detected by X-ray diffraction in these tuffs are coarse-grained $(1-3 \mathrm{~mm})$ phenocrysts that grew in the magma chamber prior to eruption. Minor constituents in these tuffs include smectite, hematite, calcite, hornblende, and mica.

Figure 4 shows mineralogical variations in the tuffs as a function of stratigraphic position for sections STRAT-1, -2 , and -3 . Within analytical error, these tuffs have the same abundances of alkali feldspar in all units. However, abundances of the silica minerals vary as a function of stratigraphic position. For example, tridymite abundances are greatest in unit 2 and in the overlying nonwelded unit. Tridymite abundances generally decrease in units 3 and 4. Cristobalite generally shows an inverse relation to the abundance of tridymite. Alkali feldspar and silica minerals are relatively resistant to transformation and should remain stable over the life time of the MWDF. These minerals have poor ion-exchange properties and probably provide little in the way of natural mineralogic barriers to contaminant migration by that mechanism. On the other hand, the surfaces of alumnosilicates have high affinities (Kds $>1000 \mathrm{ml} / \mathrm{g}$ ) for elements such as Am, $\mathrm{Nb}$, REE (rare earth elements), Sn, Th, Zr, and Pu (Allard et al., 1982; Beall and Allard, 1981; Thomas, 1987; Brandberg and Skagius, 1991; Meijer, 1992), and they may provide retardation by surface complexation.

Smectite and hematite occur in small amounts throughout the stratigraphic sequence at Pajarito Mesa. These two trace minerals are important because they are sorptive of certain radionuclides and could provide important natural barriers to their migration. Smectites are highly selective for cationic radionuclides (Grim, 1968). Magnetite and its alteration products such as hematite have an affinity for uranium and actinide species through surface-complexation (Hsi and Langmuir, 1985; Ho and Miller, 1986; Allard and Beal, 1979; Beall and Allard, 1981; Allard et al., 1982). Although these minerals occur in small quantities, they are disseminated throughout the stratigraphic sequence, and their aggregate abundance and surface area available for adsorption are probably large when integrated over long ground water flow paths through the tuffs.

\section{Chemistry}

The Tshirege Member at Pajarito Mesa ranges in composition from high-silica rhyolite (77\% $\mathrm{SiO}_{2}$ ) in Qbt 2 and Qbt 3 to rhyolite $\left(74 \% \mathrm{SiO}_{2}\right.$ ) in Qbt 4 (Table 4). Major elements vary little between $\mathrm{Qbt} 2$ and $\mathrm{Qbt} 3$, but $\mathrm{Qbt} 4$ is distinctly less silicic than the underlying units (Fig. 5). Trace element abundances vary as a function of stratigraphic height in Qbt 2 through Qbt 4, but the most pronounced changes take place across the Qbt $3 / \mathrm{Qbt} 4$ contact. In general, concentrations of $\mathrm{SiO}_{2}, \mathrm{Nb}$, and $\mathrm{Rb}$ tend to decrease upsection, whereas $\mathrm{TiO}_{2}, \mathrm{Al}_{2} \mathrm{O}_{3}, \mathrm{Fe}_{2} \mathrm{O}_{3}, \mathrm{CaO}, \mathrm{Ba}, \mathrm{Sr}, \mathrm{Zn}$, and $\mathrm{Zr}$ tend to increase (Fig. 5).

These data are consistent with earlier studies which show that the Tshirege Member is a chemically-zoned ash-flow unit (Smith and Bailey, 1966; Smith, 1979; Crowe et al., 1978). Thus, when establishing baseline conditions for the site, it must be recognized that background elemental concentrations vary as a function of stratigraphic position in the tuff sequence. Chemical compositions for the exposed portion of the Tshirege Member at Pajarito Mesa are given in Table 4.

The chemical data are also useful for establishing stratigraphic relations in boreholes where the diagnostic surface expressions of the Tshirege subunits are absent. The trace elements, particularly $\mathrm{Nb}, \mathrm{Rb}$, and $\mathrm{Zr}$, are most diagnostic of the individual Tshirege units (Fig. 5). These data may provide useful stratigraphic control when interpreting subsurface data from characterization boreholes and for selection of instrument locations in monitoring wells. 
Stratigraphic Section \#1

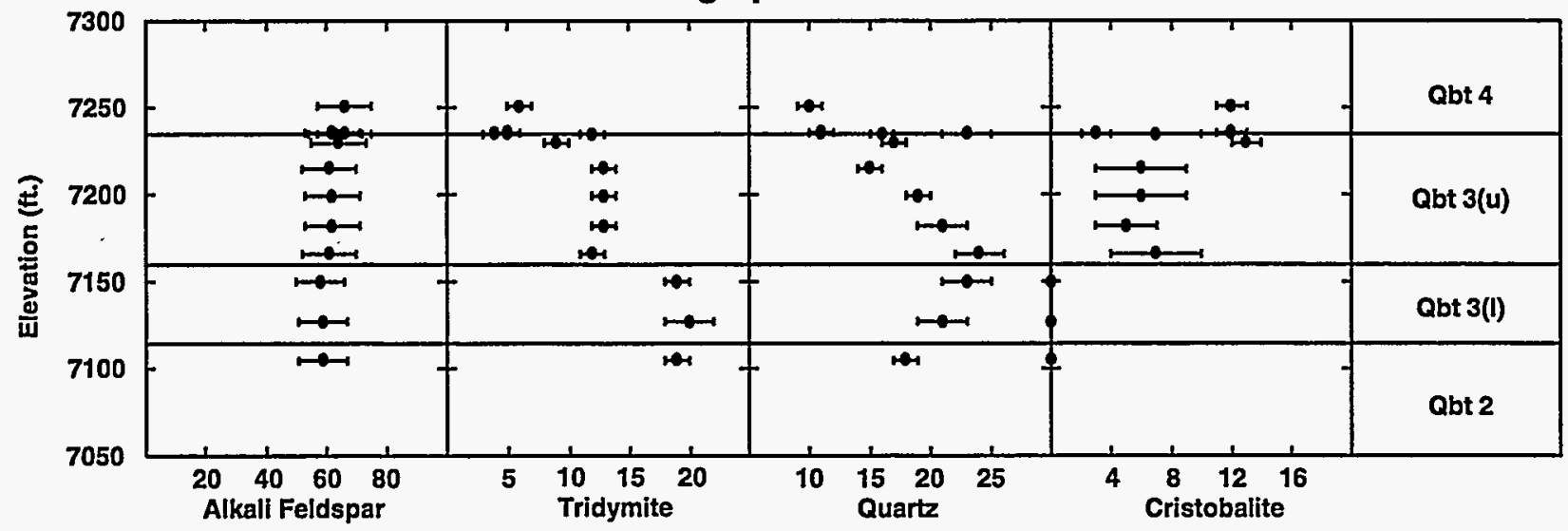

Stratigraphic Section \#2

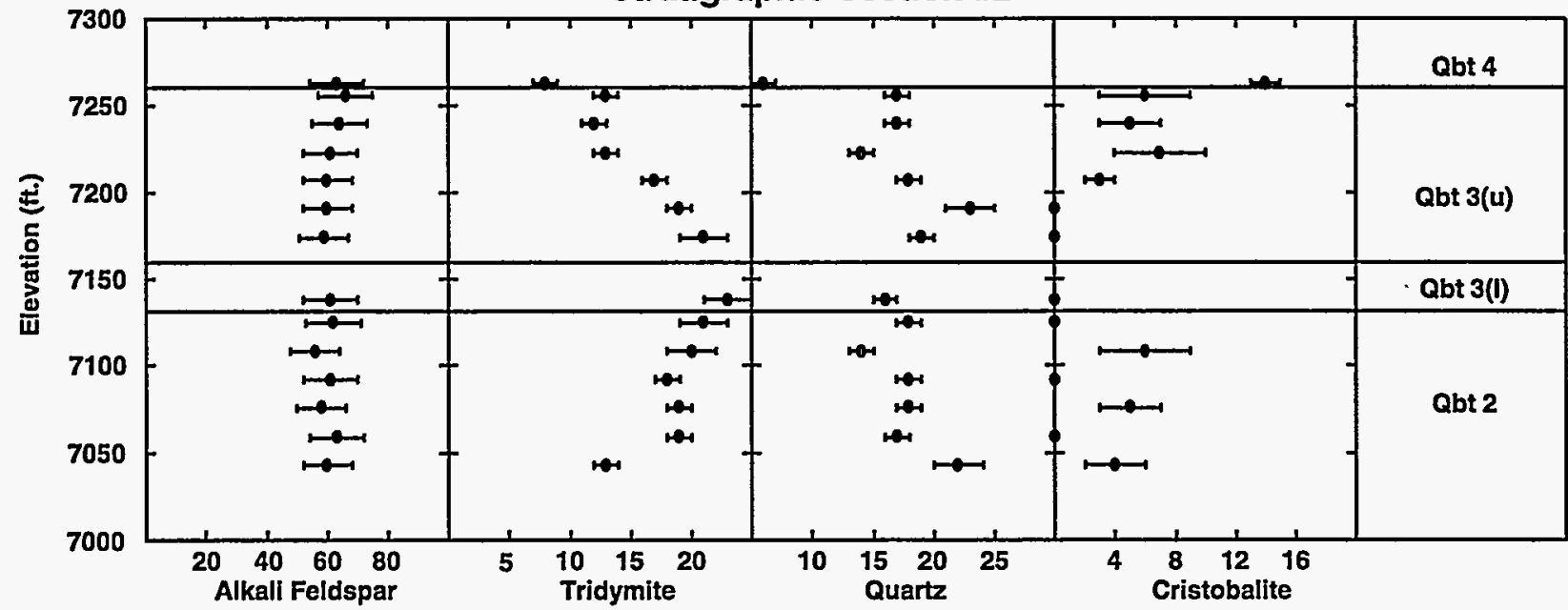

Stratigraphic Section \#3

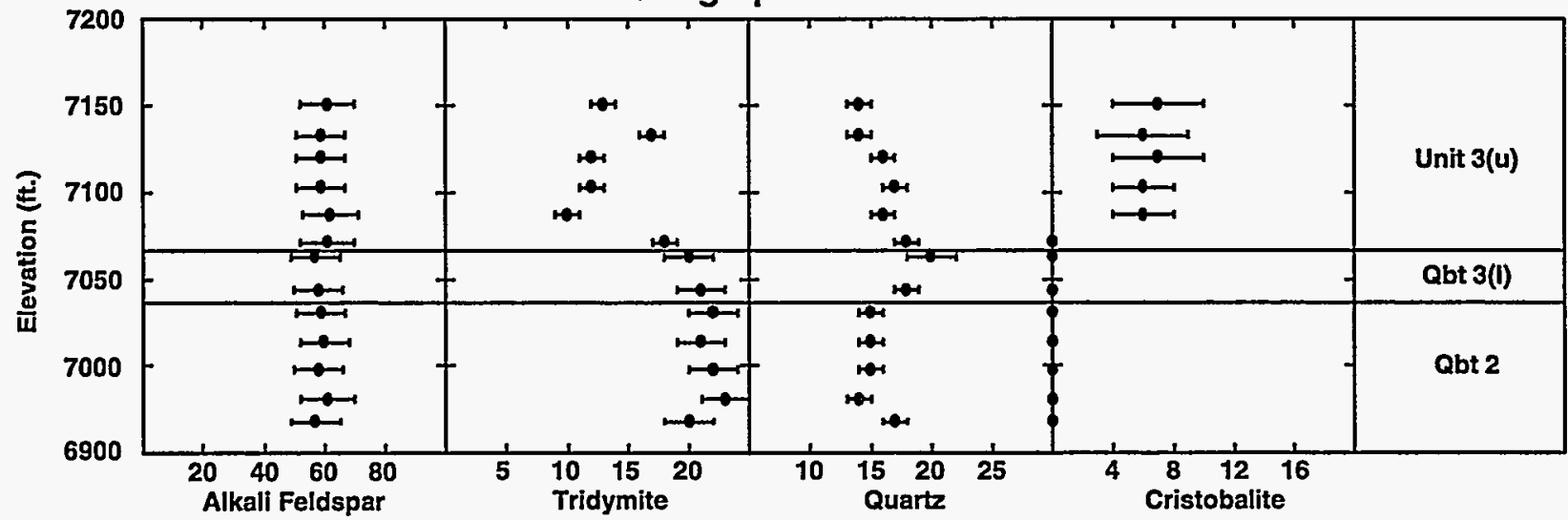

Fig. 4. Variation diagrams showing the abundance of minerals as a function of stratigraphic position at Pajarito Mesa. Alkali feldspar, the most abundant mineral, has nearly invariant abundances. However, the silica polymorphs of tridymite, quartz, and cristobalite have variable abundances which are related to degree of vapor-phase alteration. 
Table 4. Chemistry of Ash-Flow Tuffs at Pajarito Mesa, los Alamos, NM ${ }^{1}$

\begin{tabular}{|c|c|c|c|c|c|c|c|c|c|c|c|c|}
\hline $\begin{array}{l}\text { Field Number } \\
\text { Strat. Unit }{ }^{2} \\
\text { Site ID }\end{array}$ & $\begin{array}{l}1085-1-1 \\
\text { Qbt-2 } \\
67-1001\end{array}$ & $\begin{array}{l}1085-1-2 \\
\text { Qbt-nw } \\
67-1002\end{array}$ & $\begin{array}{c}1085-1-3 a \\
\text { Qbt-3 } \\
67-1003\end{array}$ & $\begin{array}{c}1085-1-4 \\
\text { Qbt-3 } \\
67-1005\end{array}$ & $\begin{array}{c}1085-1-5 \\
\text { Qbt-3 } \\
67-1006\end{array}$ & $\begin{array}{c}1085-1-6 \\
\text { Qbt-3 } \\
67-1007\end{array}$ & $\begin{array}{c}1085-1-7 \\
\text { Qbt-3 } \\
67-1008\end{array}$ & $\begin{array}{c}1085-1-8 \\
\text { Qbt-3 } \\
67-1009\end{array}$ & $\begin{array}{c}1085-1-9 A \\
\text { Qbt-3 } \\
67-1010\end{array}$ & $\begin{array}{c}1085-1-9 B \\
\text { Qbt-4 } \\
67-1011\end{array}$ & $\begin{array}{c}1085-1-9 C \\
\text { Qbt-4 } \\
67-1012\end{array}$ & $\begin{array}{c}1085-1-10 \\
\text { Qbt-4 } \\
67-1013\end{array}$ \\
\hline $\begin{array}{l}\text { XRF file } \\
\text { Fusion \# }\end{array}$ & $\begin{array}{c}\text { BRO932 } \\
4595\end{array}$ & $\begin{array}{c}\text { BRO932 } \\
4596\end{array}$ & $\begin{array}{c}\text { BRO932 } \\
4597\end{array}$ & $\begin{array}{c}\text { BRO932 } \\
4598\end{array}$ & $\begin{array}{c}\text { BRO932 } \\
4599\end{array}$ & $\begin{array}{c}\text { BRO932 } \\
4600\end{array}$ & $\begin{array}{c}\text { BRO932 } \\
4601\end{array}$ & $\begin{array}{c}\text { BRO932 } \\
4602\end{array}$ & $\begin{array}{c}\text { BRO932 } \\
4603\end{array}$ & $\begin{array}{c}\text { BRO932 } \\
4604\end{array}$ & $\begin{array}{c}\text { BRO932 } \\
4605\end{array}$ & $\begin{array}{c}\text { BRO932 } \\
4606\end{array}$ \\
\hline \multicolumn{13}{|c|}{ Major Elements (wt \%) } \\
\hline $\begin{array}{l}\mathrm{SiO}_{2} \\
\mathrm{TiO}_{2} \\
\mathrm{Al}_{2} \mathrm{O}_{3} \\
\mathrm{Fe}_{2} \mathrm{O}_{3} \\
\text { (total) }\end{array}$ & $\begin{array}{l}77.0 \pm 1.2 \\
0.09 \pm 0.02 \\
12.3 \pm 0.2 \\
1.55 \pm 0.06\end{array}$ & $\begin{array}{l}76.3 \pm 1.2 \\
0.11 \pm 0.02 \\
11.7 \pm 0.3 \\
1.86 \pm 0.07\end{array}$ & $\begin{array}{l}74.9 \pm 1.1 \\
0.06 \pm 0.02 \\
11.8 \pm 0.3 \\
1.09 \pm 0.06\end{array}$ & $\begin{array}{l}76.9 \pm 1.2 \\
0.13 \pm 0.02 \\
12.2 \pm 0.2 \\
1.47 \pm 0.06\end{array}$ & $\begin{array}{l}76.7 \pm 1.2 \\
0.12 \pm 0.02 \\
12.0 \pm 0.2 \\
1.54 \pm 0.06\end{array}$ & $\begin{array}{l}76.9 \pm 1.2 \\
0.13 \pm 0.02 \\
12.0 \pm 0.2 \\
1.59 \pm 0.06\end{array}$ & $\begin{array}{l}75.9 \pm 1.2 \\
0.14 \pm 0.01 \\
12.4 \pm 0.2 \\
1.71 \pm 0.06\end{array}$ & $\begin{array}{l}77.0 \pm 1.2 \\
0.14 \pm 0.02 \\
12.5 \pm 0.2 \\
1.64 \pm 0.06\end{array}$ & $\begin{array}{l}75.8 \pm 1.1 \\
0.14 \pm 0.01 \\
12.2 \pm 0.2 \\
1.55 \pm 0.06\end{array}$ & $\begin{array}{l}72.5 \pm 1.1 \\
0.29 \pm 0.01 \\
13.0 \pm 0.2 \\
3.04 \pm 0.07\end{array}$ & $\begin{array}{l}73.3 \pm 1.1 \\
0.24 \pm 0.01 \\
12.9 \pm 0.2 \\
2.44 \pm 0.07\end{array}$ & $\begin{array}{l}73.6 \pm 1.1 \\
0.24 \pm 0.01 \\
13.1 \pm 0.2 \\
2.26 \pm 0.07\end{array}$ \\
\hline $\begin{array}{l}\mathrm{MnO} \\
\mathrm{MgO} \\
\mathrm{CaO} \\
\mathrm{Na}_{2} \mathrm{O} \\
\mathrm{K}_{2} \mathrm{O} \\
\mathrm{P}_{2} \mathrm{O}_{5} \\
\mathrm{LOI} \%{ }^{3}\end{array}$ & $\begin{array}{l}0.05 \pm 0.01 \\
<0.09 \\
0.14 \pm 0.07 \\
3.88 \pm 0.08 \\
4.42 \pm 0.05 \\
<0.01 \\
0.40\end{array}$ & $\begin{array}{l}0.02 \pm 0.01 \\
0.10 \pm 0.09 \\
0.30 \pm 0.07 \\
3.96 \pm 0.08 \\
4.25 \pm 0.05 \\
<0.01 \\
0.15\end{array}$ & $\begin{array}{l}0.03 \pm 0.01 \\
<0.09 \\
0.18 \pm 0.07 \\
5.37 \pm 0.12 \\
4.06 \pm 0.05 \\
<0.01 \\
1.36\end{array}$ & $\begin{array}{l}0.05 \pm 0.01 \\
<0.09 \\
0.26 \pm 0.07 \\
4.06 \pm 0.08 \\
4.36 \pm 0.05 \\
<0.01 \\
0.10\end{array}$ & $\begin{array}{l}0.05 \pm 0.01 \\
0.10 \pm 0.09 \\
0.27 \pm 0.07 \\
4.04 \pm 0.08 \\
4.47 \pm 0.05 \\
0.02 \pm 0.1 \\
0.11\end{array}$ & $\begin{array}{l}0.05 \pm 0.01 \\
<0.09 \\
0.22 \pm 0.07 \\
4.02 \pm 0.08 \\
4.41 \pm 0.05 \\
<0.01 \\
0.18\end{array}$ & $\begin{array}{l}0.06 \pm 0.01 \\
<0.09 \\
0.31 \pm 0.07 \\
4.03 \pm 0.08 \\
4.46 \pm 0.05 \\
0.02 \pm 0.1 \\
0.34\end{array}$ & $\begin{array}{l}0.05 \pm 0.01 \\
<0.09 \\
0.30 \pm 0.07 \\
4.04 \pm 0.08 \\
4.52 \pm 0.05 \\
<0.01 \\
0.28\end{array}$ & $\begin{array}{l}0.04 \pm 0.01 \\
0.10 \pm 0.09 \\
0.56 \pm 0.07 \\
4.08 \pm 0.08 \\
4.44 \pm 0.05 \\
<0.01 \\
0.73\end{array}$ & $\begin{array}{l}0.07 \pm 0.01 \\
0.39 \pm 0.9 \\
0.61 \pm 0.07 \\
3.81 \pm 0.08 \\
4.15 \pm 0.05 \\
<0.01 \\
1.31\end{array}$ & $\begin{array}{l}0.07 \pm 0.01 \\
0.29 \pm 0.09 \\
0.64 \pm 0.07 \\
4.00 \pm 0.08 \\
4.52 \pm 0.05 \\
0.05 \pm 0.01 \\
1.07\end{array}$ & $\begin{array}{l}0.07 \pm 0.01 \\
0.16 \pm 0.09 \\
0.48 \pm 0.07 \\
4.42 \pm 0.09 \\
4.69 \pm 0.05 \\
0.02 \pm 0.01 \\
0.43\end{array}$ \\
\hline Total & 99.8 & 98.8 & 98.9 & 99.6 & 99.5 & 99.6 & 99.5 & 100.5 & 99.7 & 99.3 & 99.7 & 99.5 \\
\hline \multicolumn{13}{|c|}{ Trace Elements (ppm) } \\
\hline
\end{tabular}

${ }^{1}$ Elemental abundances determined by X-ray fluorescence; uncertainties are two standard deviation estimates of analytical precision.

${ }^{2}$ Strat. Unit - Qbt $2=$ Tshirege unit 2; Qbt 3(l) = Tshirege unit 3, lower part; Qbt 3(u) = Tshirege unit 3, upper part; $Q b t 4=$ Tshirege unit 4.

${ }^{3} \mathrm{LOI}=$ Loss on ignition. 
Table 4. Chemistry of Ash-Flow Tuffs at Pajarito Mesa, los Alamos, NM$^{1}$ (cont.)

\begin{tabular}{|c|c|c|c|c|c|c|c|c|c|c|c|c|c|}
\hline $\begin{array}{l}\text { Feld Number } \\
\text { Strat. Unit }{ }^{2} \\
\text { Site ID }\end{array}$ & $\begin{array}{c}1085-3-1 \\
\text { Qbt-2 } \\
67-1028\end{array}$ & $\begin{array}{c}1085-3-2 \\
\text { Qbt-2 } \\
67-1029\end{array}$ & $\begin{array}{c}1085-3-3 \\
\text { Qbt-2 } \\
67-1030\end{array}$ & $\begin{array}{c}1085-3-4 \\
\text { Qbt-2 } \\
67-1031\end{array}$ & $\begin{array}{c}1085-3-5 \\
\text { Qbt-2 } \\
67-1032\end{array}$ & $\begin{array}{c}1085-3-6 \\
\text { Qbt-nw } \\
67-1033\end{array}$ & $\begin{array}{c}1085-3-7 a \\
\text { Qbt-nw } \\
67-1034\end{array}$ & $\begin{array}{c}1085-3-8 \\
\text { Qbt-3 } \\
67-1036\end{array}$ & $\begin{array}{c}1085-3-9 \\
\text { Qbt-3 } \\
67-1037\end{array}$ & $\begin{array}{c}1085-3-10 \\
\text { Qbt-3 } \\
67-1038\end{array}$ & $\begin{array}{c}1085-3-11 \\
\text { Qbt-3 } \\
67-1039\end{array}$ & $\begin{array}{c}1085-3-12 \\
\text { Qbt-3 } \\
67-1040\end{array}$ & $\begin{array}{c}1085-3-13 \\
\text { Qbt-3 } \\
67-1041\end{array}$ \\
\hline $\begin{array}{l}\text { XRF file } \\
\text { Fusion \# }\end{array}$ & $\begin{array}{c}\text { BRO932 } \\
4607 \\
\end{array}$ & $\begin{array}{c}\text { BRO932 } \\
4608 \\
\end{array}$ & $\begin{array}{c}\text { BRO932 } \\
4609\end{array}$ & $\begin{array}{c}\text { BRO932 } \\
4610\end{array}$ & $\begin{array}{c}\text { BR0932 } \\
4611 \\
\end{array}$ & $\begin{array}{c}\text { BRO932 } \\
4612 \\
\end{array}$ & $\begin{array}{c}\text { BRO932 } \\
4613 \\
\end{array}$ & $\begin{array}{c}\text { BRO932 } \\
4614 \\
\end{array}$ & $\begin{array}{c}\text { BRO932 } \\
4615 \\
\end{array}$ & $\begin{array}{c}\text { BRO932 } \\
4616 \\
\end{array}$ & $\begin{array}{c}\text { BRO932 } \\
4617\end{array}$ & $\begin{array}{c}\text { BRO932 } \\
4618 \\
\end{array}$ & $\begin{array}{c}\text { BR0932 } \\
4619 \\
\end{array}$ \\
\hline \multicolumn{14}{|c|}{ Major Elements (wt \%) } \\
\hline $\begin{array}{l}\mathrm{SIO}_{2} \\
\mathrm{TiO}_{2} \\
\mathrm{Al}_{2} \mathrm{O}_{3} \\
\mathrm{Fe}_{2} \mathrm{O}_{3} \\
\text { (total) }\end{array}$ & $\begin{array}{l}77.8 \pm 1.2 \\
0.09 \pm 0.02 \\
11.7 \pm 0.3 \\
1.46 \pm 0.06\end{array}$ & $\begin{array}{l}77.3 \pm 1.2 \\
0.09 \pm 0.02 \\
11.8 \pm 0.3 \\
1.48 \pm 0.06\end{array}$ & $\begin{array}{l}76.7 \pm 1.2 \\
0.10 \pm 0.02 \\
12.2 \pm 0.2 \\
1.57 \pm 0.06\end{array}$ & $\begin{array}{l}76.8 \pm 1.2 \\
0.09 \pm 0.02 \\
12.1 \pm 0.2 \\
1.54 \pm 0.06\end{array}$ & $\begin{array}{l}77.0 \pm 1.2 \\
0.09 \pm 0.02 \\
12.2 \pm 0.2 \\
1.49 \pm 0.06\end{array}$ & $\begin{array}{l}76.9 \pm 1.2 \\
0.11 \pm 0.02 \\
12.3 \pm 0.2 \\
1.79 \pm 0.06\end{array}$ & $\begin{array}{l}78.0 \pm 1.2 \\
0.10 \pm 0.02 \\
11.7 \pm 0.3 \\
1.43 \pm 0.06\end{array}$ & $\begin{array}{l}78.0 \pm 1.2 \\
0.10 \pm 0.02 \\
11.9 \pm 0.2 \\
1.37 \pm 0.06\end{array}$ & $\begin{array}{l}76.9 \pm 12 \\
0.12 \pm 0.02 \\
11.8 \pm 0.3 \\
1.50 \pm 0.06\end{array}$ & $\begin{array}{l}76.2 \pm 1.2 \\
0.12 \pm 0.02 \\
12.0 \pm 0.2 \\
1.51 \pm 0.06\end{array}$ & $\begin{array}{l}76.2 \pm 1.2 \\
0.12 \pm 0.02 \\
12.2 \pm 0.2 \\
1.58 \pm 0.06\end{array}$ & $\begin{array}{l}76.6 \pm 1.2 \\
0.13 \pm 0.02 \\
12.7 \pm 0.2 \\
1.65 \pm 0.06\end{array}$ & $\begin{array}{l}76.2 \pm 1.2 \\
0.14 \pm 0.01 \\
12.5 \pm 0.2 \\
1.65 \pm 0.06\end{array}$ \\
\hline $\begin{array}{l}\mathrm{MnO} \\
\mathrm{MgO} \\
\mathrm{CaO} \\
\mathrm{Na}_{2} \mathrm{O}\end{array}$ & $\begin{array}{l}0.06 \pm 0.01 \\
<0.09 \\
0.21 \pm 0.07 \\
3.91 \pm 0.08\end{array}$ & $\begin{array}{l}0.06 \pm 0.01 \\
<0.09 \\
0.13 \pm 0.07 \\
3.98 \pm 0.08\end{array}$ & $\begin{array}{l}0.08 \pm 0.01 \\
<0.09 \\
0.15 \pm 0.07 \\
3.89 \pm 0.08\end{array}$ & $\begin{array}{l}0.06 \pm 0.01 \\
<0.09 \\
0.12 \pm 0.07 \\
3.92 \pm 0.08\end{array}$ & $\begin{array}{l}0.06 \pm 0.01 \\
<0.09 \\
0.13 \pm 0.07 \\
3.88 \pm 0.08\end{array}$ & $\begin{array}{l}0.04 \pm 0.01 \\
0.12 \pm 0.09 \\
0.20 \pm 0.07 \\
3.68 \pm 0.07\end{array}$ & $\begin{array}{l}0.05 \pm 0.01 \\
<0.09 \\
0.26 \pm 0.07 \\
3.96 \pm 0.08\end{array}$ & $\begin{array}{l}0.05 \pm 0.01 \\
<0.09 \\
0.29 \pm 0.07 \\
4.07 \pm 0.08\end{array}$ & $\begin{array}{l}0.05 \pm 0.01 \\
<0.09 \\
0.25 \pm 0.07 \\
4.04 \pm 0.08\end{array}$ & $\begin{array}{l}0.05 \pm 0.01 \\
<0.09 \\
0.27 \pm 0.07 \\
3.98 \pm 0.08\end{array}$ & $\begin{array}{l}0.05 \pm 0.01 \\
<0.09 \\
0.43 \pm 0.07 \\
4.09 \pm 0.08\end{array}$ & $\begin{array}{l}0.06 \pm 0.0 .1 \\
<0.09 \\
0.18 \pm 0.07 \\
4.08 \pm 0.08\end{array}$ & $\begin{array}{l}0.05 \pm 0.01 \\
<0.09 \\
0.26 \pm 0.07 \\
4.05 \pm 0.08\end{array}$ \\
\hline $\begin{array}{l}\mathrm{K}_{2} \mathrm{O} \\
\mathrm{P}_{2} \mathrm{O}_{5} \\
\mathrm{LOl} \%{ }^{3}\end{array}$ & $\begin{array}{l}4.30 \pm 0.05 \\
<0.01 \\
0.30\end{array}$ & $\begin{array}{l}4.44 \pm 0.05 \\
<0.01 \\
0.23\end{array}$ & $\begin{array}{l}4.47 \pm 0.05 \\
0.02 \pm 0.01 \\
0.40\end{array}$ & $\begin{array}{l}4.45 \pm 0.05 \\
<0.01 \\
0.37\end{array}$ & $\begin{array}{l}4.47 \pm 0.05 \\
<0.01 \\
0.50\end{array}$ & $\begin{array}{l}4.07 \pm 0.05 \\
<0.01 \\
0.98\end{array}$ & $\begin{array}{l}4.35 \pm 0.05 \\
<0.01 \\
0.12\end{array}$ & $\begin{array}{l}4.40 \pm 0.05 \\
<0.01 \\
0.06\end{array}$ & $\begin{array}{l}4.46 \pm 0.05 \\
<0.01 \\
0.18\end{array}$ & $\begin{array}{l}4.37 \pm 0.05 \\
<0.01 \\
0.32\end{array}$ & $\begin{array}{l}4.50 \pm 0.05 \\
<0.01 \\
0.37\end{array}$ & $\begin{array}{l}4.61 \pm 0.05 \\
<0.01 \\
0.38\end{array}$ & $\begin{array}{l}4.46 \pm 0.05 \\
<0.01 \\
0.42\end{array}$ \\
\hline Total & 100.0 & 99.6 & 99.7 & 99.5 & 99.9 & 100.3 & 100.1 & 100.3 & 99.4 & 98.9 & 99.7 & 100.5 & 99.9 \\
\hline \multicolumn{14}{|c|}{ Trace Elements (ppm) } \\
\hline $\begin{array}{l}\mathrm{V} \\
\mathrm{Cr} \\
\mathrm{Ni} \\
\mathrm{Zn} \\
\mathrm{Rb} \\
\mathrm{Sr} \\
\mathrm{Y} \\
\mathrm{Zr} \\
\mathrm{Nb} \\
\mathrm{Ba}\end{array}$ & $\begin{array}{l}7 \pm 7 \\
<9 \\
<7 \\
66 \pm 10 \\
134 \pm 7 \\
23 \pm 6 \\
51 \pm 5 \\
201 \pm 15 \\
65 \pm 11 \\
89 \pm 19\end{array}$ & $\begin{array}{l}<7 \\
<9 \\
<7 \\
74 \pm 11 \\
141 \pm 7 \\
21 \pm 6 \\
56 \pm 5 \\
206 \pm 15 \\
72 \pm 12 \\
89 \pm 19\end{array}$ & $\begin{array}{l}<7 \\
<9 \\
<7 \\
80 \pm 11 \\
137 \pm 7 \\
21 \pm 6 \\
53 \pm 5 \\
211 \pm 15 \\
71 \pm 12 \\
107 \pm 19\end{array}$ & $\begin{array}{l}<7 \\
<9 \\
<7 \\
64 \pm 10 \\
134 \pm 7 \\
18 \pm 6 \\
36 \pm 4 \\
220 \pm 15 \\
71 \pm 12 \\
78 \pm 19\end{array}$ & $\begin{array}{l}<7 \\
<9 \\
<7 \\
70 \pm 10 \\
134 \pm 7 \\
16 \pm 6 \\
48 \pm 5 \\
209 \pm 15 \\
71 \pm 12 \\
105 \pm 19\end{array}$ & $\begin{array}{l}7 \pm 7 \\
<9 \\
<7 \\
40-9 \\
119 \pm 7 \\
24 \pm 6 \\
29 \pm 5 \\
194 \pm 15 \\
59 \pm 11 \\
115 \pm 19\end{array}$ & $\begin{array}{l}<7 \\
<9 \\
<7 \\
71 \pm 11 \\
111 \pm 6 \\
29 \pm 6 \\
41 \pm 4 \\
207 \pm 15 \\
55 \pm 11 \\
126 \pm 19\end{array}$ & $\begin{array}{l}<7 \\
<9 \\
<7 \\
61 \pm 10 \\
103 \pm 6 \\
27 \pm 6 \\
37 \pm 5 \\
213 \pm 15 \\
53 \pm 11 \\
154 \pm 19\end{array}$ & $\begin{array}{l}<7 \\
<9 \\
<7 \\
61 \pm 10 \\
102 \pm 6 \\
29 \pm 6 \\
41 \pm 4 \\
228 \pm 15 \\
50 \pm 11 \\
160 \pm 20\end{array}$ & $\begin{array}{l}<7 \\
<9 \\
<7 \\
46 \pm 9 \\
101 \pm 6 \\
29 \pm 6 \\
41 \pm 5 \\
221 \pm 15 \\
54 \pm 11 \\
130 \pm 19\end{array}$ & $\begin{array}{l}<7 \\
<9 \\
<7 \\
68 \pm 10 \\
106 \pm 6 \\
32 \pm 6 \\
48 \pm 5 \\
236 \pm 15 \\
51 \pm 11 \\
140 \pm 19\end{array}$ & $\begin{array}{l}7 \pm 7 \\
<9 \\
<7 \\
54 \pm 10 \\
100 \pm 6 \\
27 \pm 6 \\
31 \pm 4 \\
280 \pm 16 \\
52 \pm 11 \\
146 \pm 19 \\
\end{array}$ & $\begin{array}{l}<7 \\
<9 \\
<7 \\
52 \pm 10 \\
98 \pm 6 \\
35 \pm 6 \\
33 \pm 5 \\
254 \pm 16 \\
48 \pm 11 \\
180 \pm 20\end{array}$ \\
\hline
\end{tabular}

${ }^{1}$ Elemental abundances determined by X-ray fluorescence; uncertainties are two standard deviation estimates of analytical precision.

${ }^{2}$ Strat. Unit $-Q b t 2=$ Tshirege unit 2; Qbt $3(l)=$ Tshirege unit 3, lower part; Qbt $3(u)=$ Tshirege unit 3, upper part; Qbt $4=$ Tshirege unit 4.

${ }^{3} \mathrm{LOI}=$ Loss on ignition. 

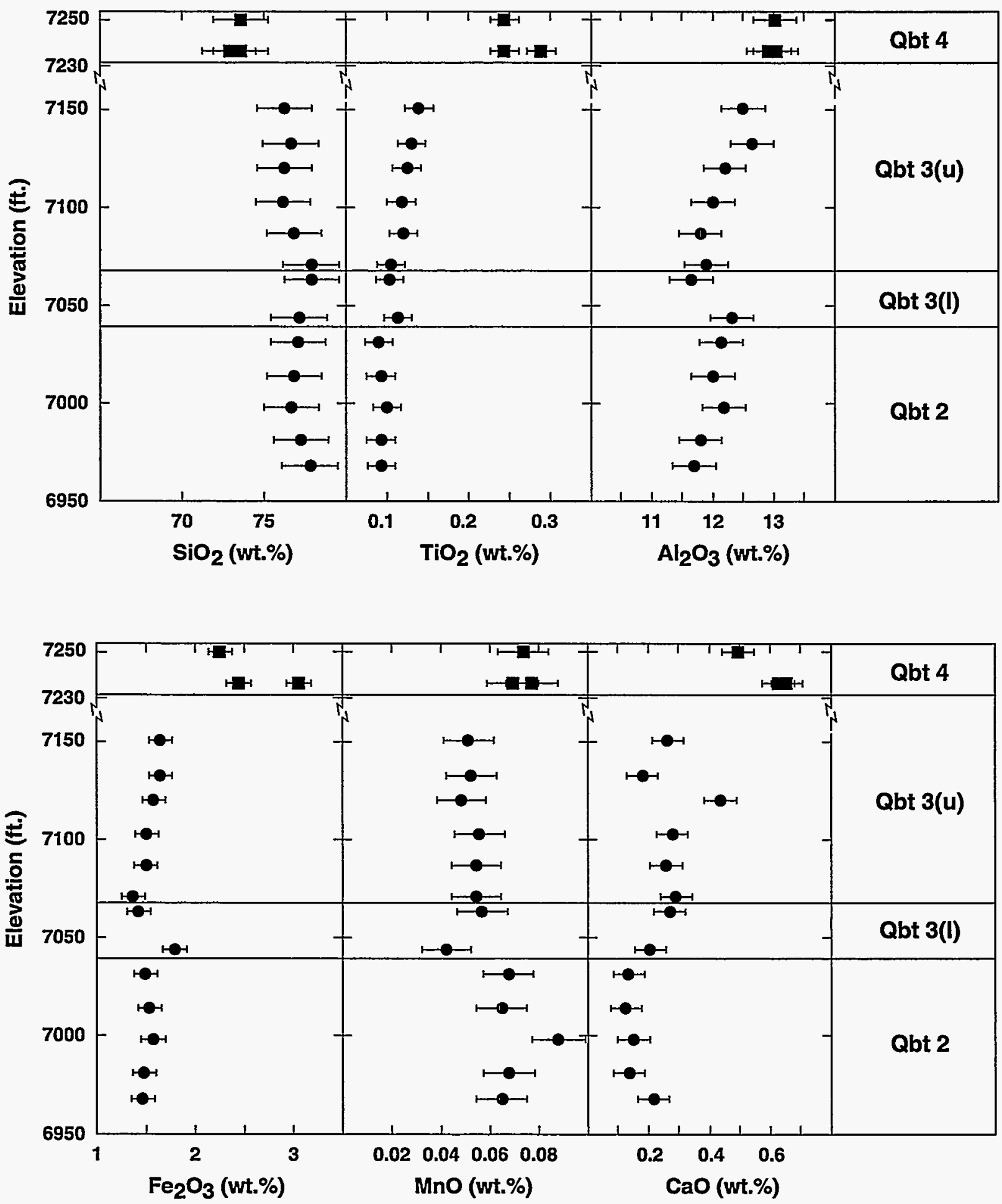

Fig. 5. Variation diagrams showing elemental concentrations in the Tshirege Member as a function of stratigraphic position at Pajarito Mesa; all analyses by $X$-ray fluorescence. This is a composite diagram for the entire exposed section. Qbt 2, Qbt 3(l), and Qbt 3(u) data are for stratigraphic section 3, and Qbt 4 data are for stratigraphic section 1. 

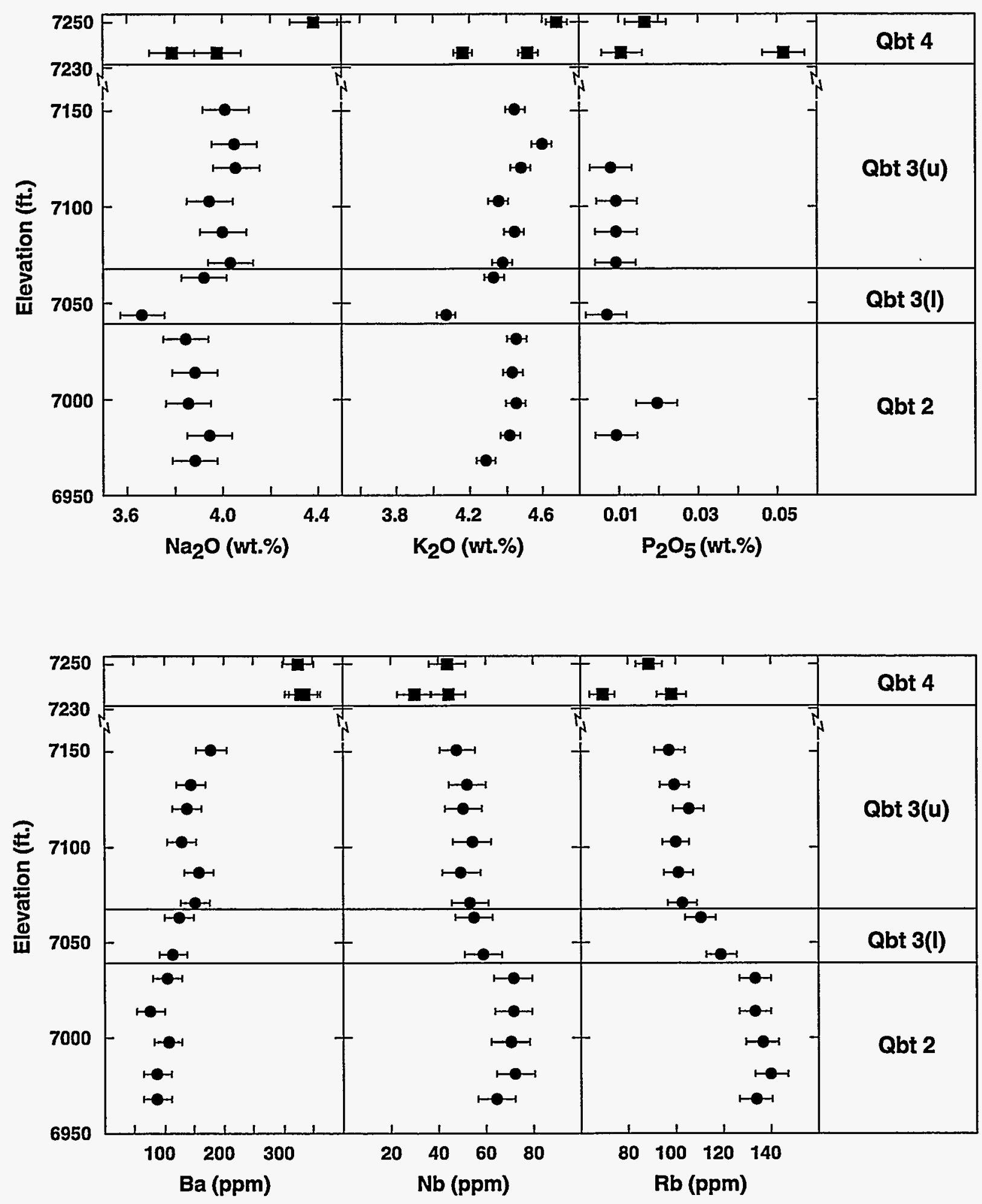

Fig. 5. (cont.) 

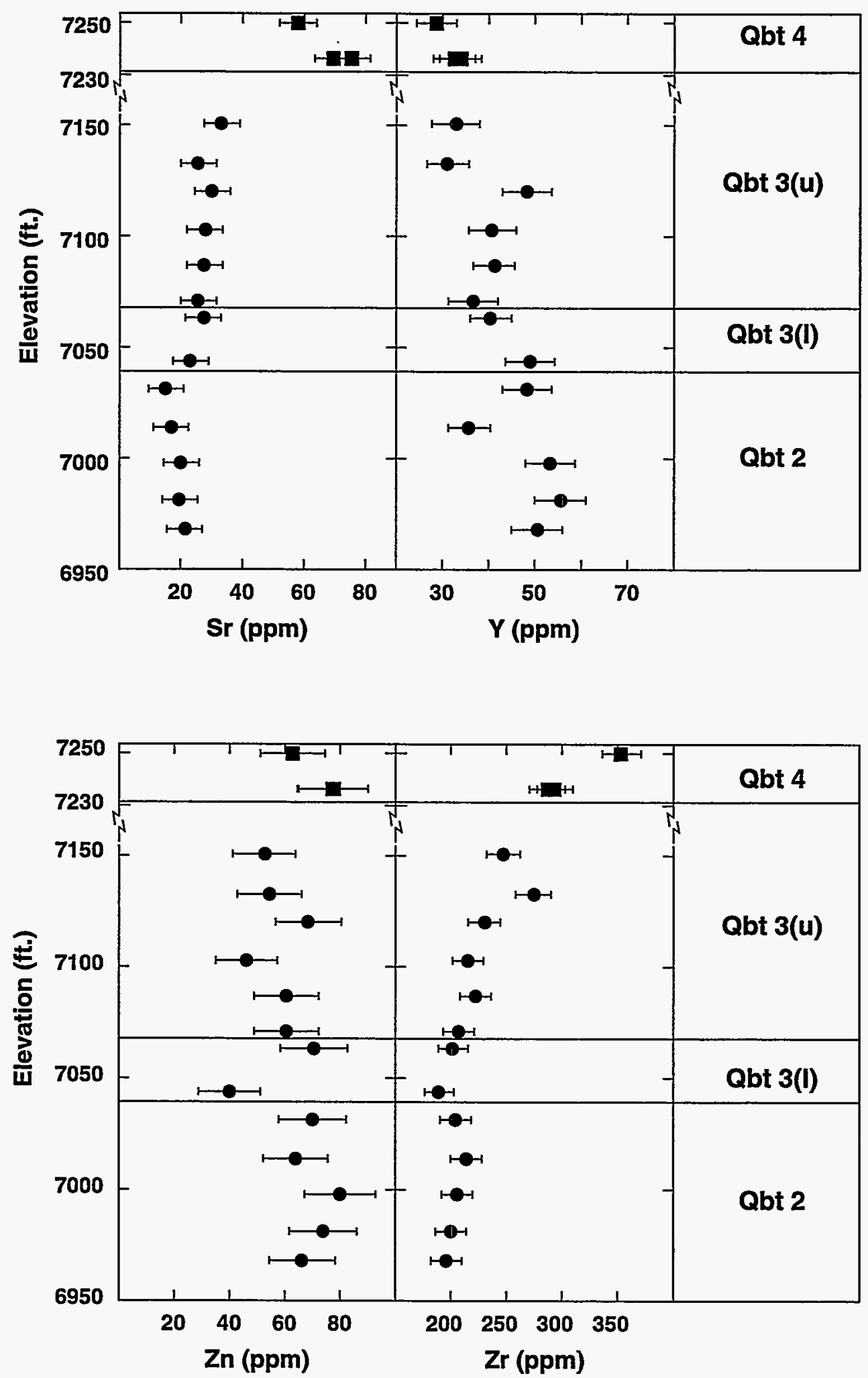

Fig. 5. (cont.) 


\section{Cross Sections}

Geologic cross sections for PS-1 and PS-2 are presented in Figures 6 and 7, respectively. These cross sections show the distribution and thickness of stratigraphic units at Pajarito Mesa.

Present plans call for construction of a single long 25-foot-deep waste disposal cell at PS1 (Fig. 6). The western part of the proposed disposal cell will be located in Qbt 3(u) and Qbt 4 and in overlying post-Bandelier surficial deposits (Fig. 6, sections A-A' and D-D'). Excavations in the eastern part of the proposed cell will be located entirely in $\mathrm{Qbt} 3(\mathrm{u})$ and in overlying alluvium (Fig. 6 , sections $C-C^{\prime}$ and $\left.D^{-} D^{\prime}\right)$. The centerline of the mesa is underlain by competent, but easily excavated tuffs. Excavation near the mesa margins will encounter partially- to moderately-welded tuffs which are harder than the tuffs along the centerline of the mesa. The proposed waste disposal cell is not deep enough to penetrate the Qbt $3(\mathrm{I})$, which is soft, non-indurated, and may form unstable walls.

Direct field measurements of strike and dip in the tuffs at Pajarito Mesa are difficult and unreliable. The massive nature of the tuffs provides few opportunities for direct measurement of planar bedding features. In Qbt 2, measurements of welding-induced foliation show a large amount of scatter because small irregularities in bedding will cause major local variations in strike where dips are less than $10^{\circ}$. Cross sections show that there is both a southerly and an easterly component to dip for the Tshirege Member (Figs. 6 and 7). In addition, the top of the mesa is essentially a dipslope surface, with the progressive decrease in the elevation of the mesa top eastward indicating an easterly component of dip.

The strike and dip of the Tshirege Member were estimated graphically using three widelyseparated points at the contact between Qbt 3(l) and Qbt 3(u) (Fig. 8). The use of a three-point graphical solution is commonly used for gently dipping beds where three points on the same contact lie at different elevations (Compton, 1962). Construction of the graphical solution requires that the distances and directions between the three points be known, as well as the differences in elevation between them. The $\mathrm{Qbt} 3(\mathrm{l})$ and $\mathrm{Qbt} 3(\mathrm{u})$ contact was selected because it is easily recognized and widely exposed in Threemile and Pajarito Canyons, and it is one of the best constrained of the exposed contacts. Based on this three-point solution, the orientation of the Tshirege Member at Pajarito Mesa is approximately $\mathrm{N}^{\circ} 0^{\circ} \mathrm{E}, 1.4^{\circ} \mathrm{SE}$ (Fig. 8). The strike and dip data suggest that ground water moving downward through the porous matrix of the Tshirege Member will tend to be diverted in a southeasterly direction at unit contacts or at major changes in lithology.

Some uncertainties are associated with the graphical determination of strike and dip, although uncertainties have been reduced by the use of surveyed data for $X, Y$, and elevation data for reference points used to make the 3-point projections. Remaining uncertainties include the placement of the contact between $\mathrm{Qbt} 3(\mathrm{l})$ and $\mathrm{Qbt} 3(\mathrm{u})$ in the field. The contact can usually be placed within a meter of vertical section at most locations. An aggregate error for misplacing the elevation of the contacts by as much as $1 \mathrm{~m}$ at each of the reference points used for the graphical determination can affect the strike by as much as $8^{\circ}$. Dip is little affected $\left(<0.10^{\circ}\right)$ by a $1 \mathrm{~m}$ error in contact elevation because of the long distances between the reference points used to construct the graphical determination. In addition, errors may be introduced in the strike and dip determinations by the presence of undetected small-displacement faults between the three reference points. Errors introduced by faulting are probably no greater than those cited above if the aggregate displacement is less than $2 \mathrm{~m}$ between the reference points. 

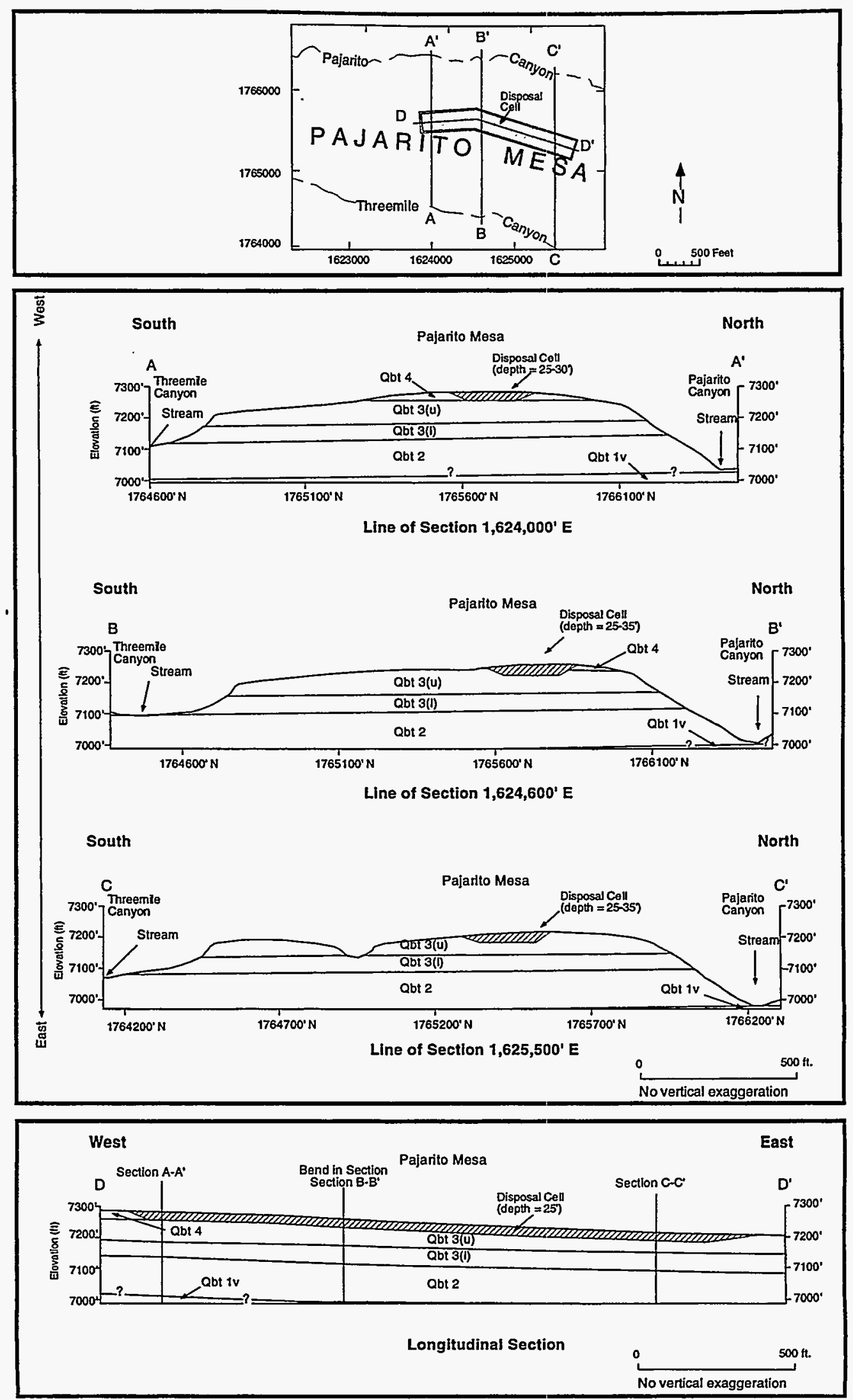

Note: Surticial deposits occur on top of Pajarito Mesa but are too thin to be shown at the scale of these cross sections.

Fig. 6. Cross sections across the potential disposal cell area (PS-1), Pajarito Mesa. 


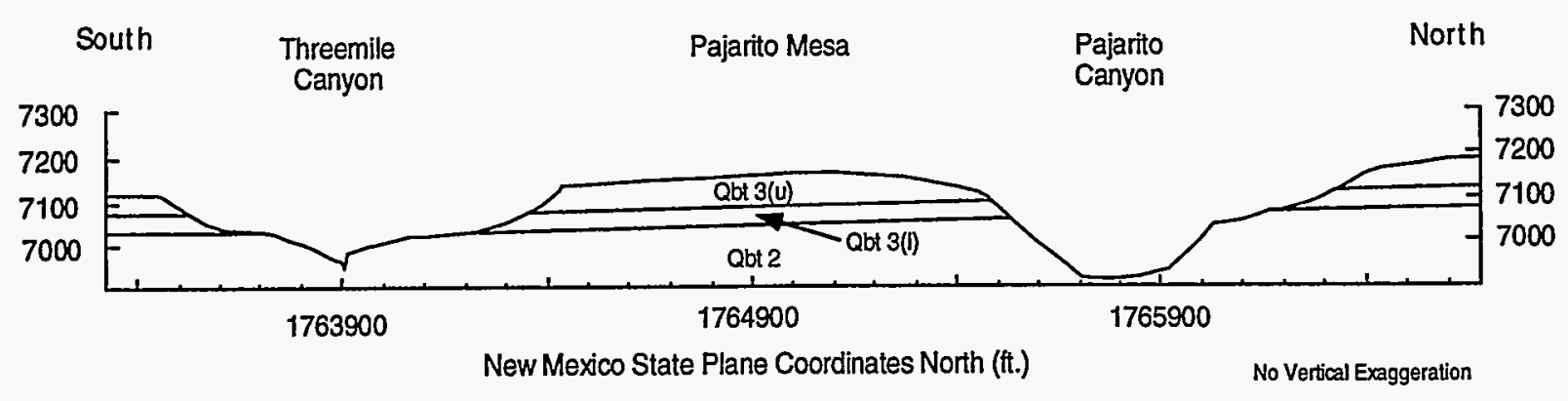

Fig. 7. North-South cross section across the central part of Pajarito Mesa at 487800 east longitude (PS-2).

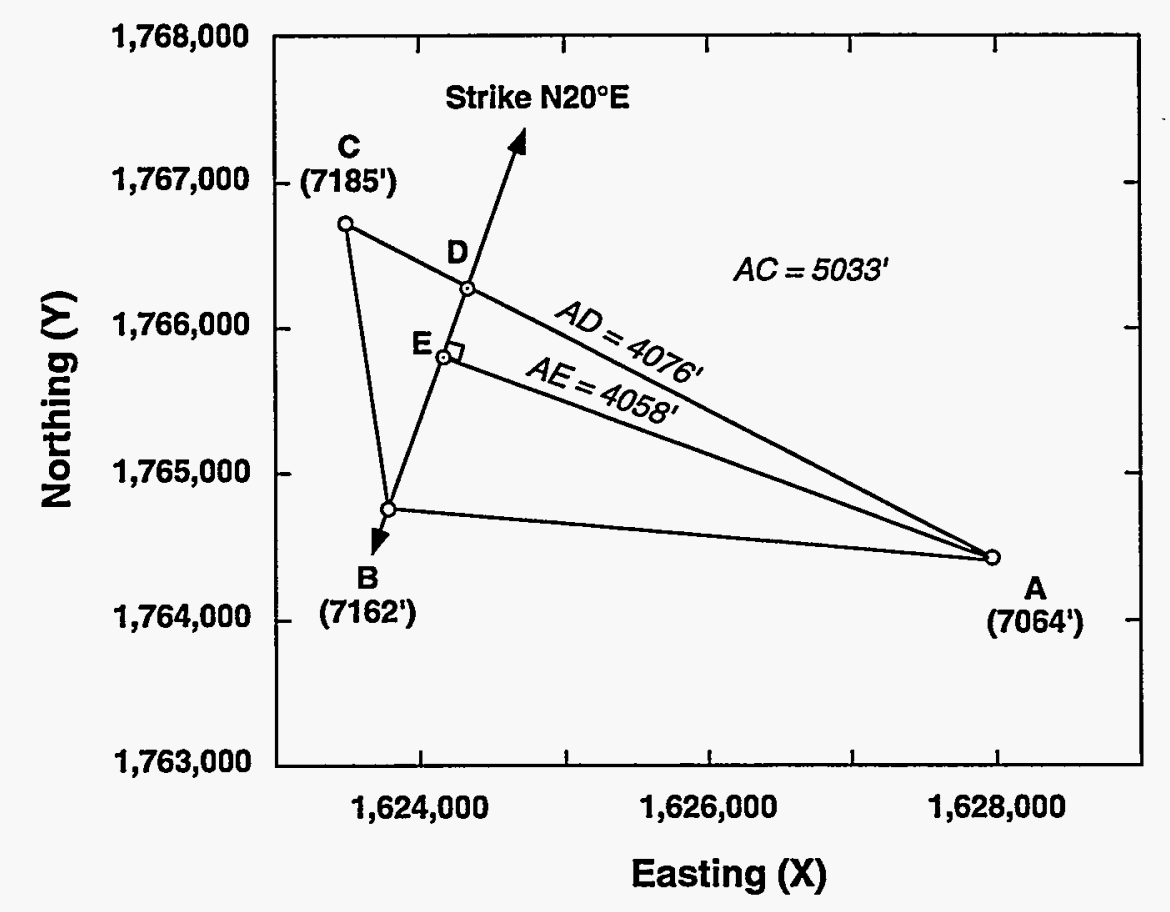

$$
\begin{aligned}
A D & =\frac{\text { Difference in elev. between } A \text { and } B}{\text { Difference in elev. between } A \text { and } C} \times A C \\
& =\frac{98^{\prime}}{121^{\prime}} \times 5033^{\prime} \\
& =4076^{\prime}
\end{aligned}
$$

$$
\begin{aligned}
\text { Dip } & =\operatorname{Tan}^{-1} \times \frac{\text { Difference in elev. between } A \text { and } B}{98^{\prime}} \\
& =\operatorname{Tan}^{-1} \frac{8^{\prime}}{4058^{\prime}} \\
& =1.38^{\circ} .
\end{aligned}
$$

Flg.8. Graphic solution to 3 point problem for determining the dip on Qbt 3 of the Bandelier Tuff. Points A, B, and $C$ are plotted at the boundary between $Q b t 3(I)$ and $Q b t 3(u)$ at stratigraphic section sample sites $O U-1085-$ STRAT3-8, OU-1085-STRAT1-3, and OU-1085-STRAT2-8, respectively. 


\section{CONCLUSIONS}

The Tshirege Member of the Bandelier Tuff is a multiple-flow ash-flow sheet that forms prominent cliffs and benches at Pajarito Mesa. It is a compound cooling unit whose physical properties vary both vertically and laterally. These variations in physical properties result from zonal patterns of welding and crystallization.

The exposed portion of the Tshirege Member in Threemile and Pajarito Canyons consists of, in ascending order: 1) Qbt 2, a lower, hard, cliff-forming unit in the canyon bottoms, 2) Qbt 3(I), a soft, poorly-consolidated tuff that forms a broad sloping bench, and 3) Qbt 3(u), an upper cliffforming unit that forms the caprock of Pajarito Mesa. In the western part of the study area, at PS1 , the caprock is overlain by Qbt 4 , a thin nonwelded to partially-welded sequence of tuffs that forms a low ridge.

The bulk-tuff mineralogy of the Tshirege Member at Pajarito Mesa is relatively simple, consisting primarily (>95\%) of alkali feldspar, tridymite, quartz, and cristobalite. Alkali feldspar and silica minerals are relatively resistant to transformation and should remain stable over the life time of the MWDF. Smectite and hematite, which occur in small amounts throughout the stratigraphic sequence, are important because they are sorptive of certain radionuclides and could provide important natural barriers to their migration. Although these minerals occur in small quantities, they are disseminated throughout the stratigraphic sequence, and their aggregate abundance and surface area available for adsorption are probably large when integrated over long ground water flow paths through the tuffs.

The Tshirege Member at Pajarito Mesa ranges in composition from high-silica rhyolite $(77 \%$ $\left.\mathrm{SiO}_{2}\right)$ in $\mathrm{Qbt} 2$ and $\mathrm{Qbt} 3$ to rhyolite $\left(74 \% \mathrm{SiO}_{2}\right)$ in Qbt 4. Major elements vary little between $\mathrm{Qbt} 2$ and $Q b t 3$, but $Q b t 4$ is distinctly less silicic than the underlying units. Trace elements compositions vary as a function of stratigraphic height in Qbt 2 through $\mathrm{Qbt} 4$, but the most pronounced changes take place across the Qbt 3(u)/Qbt 4 contact.

Present plans call for construction of a single long 25- to 35-foot-deep waste disposal cell in the western part of the study area (at PS-1). The western part of the proposed disposal cell will be entirely located in Qbt 3(u) and Qbt 4 and in overlying post-Bandelier alluvial deposits. Excavations in the eastern part of the proposed cell will be located entirely in Qbt $3(u)$ and in overlying surficial deposits. The centerline of the mesa is underlain by competent, but easily excavated tuffs.

Based on a three-point graphical solution, the orientation of the Tshirege Member at Pajarito Mesa is approximately $\mathrm{N} 20^{\circ} \mathrm{E}, 1.4^{\circ} \mathrm{SE}$. The strike and dip data suggest that ground water moving downward through the porous matrix of the Tshirege Member will tend to be diverted in a southeasterly direction at unit contacts or at major changes in lithology. Some uncertainties are associated with this graphical determination of strike and dip. The major uncertainties are associated with identifying the elevation of the contact for the subunits used for this graphical determination and for errors introduced by the presence of undetected small-displacement faults between the three reference points.

\section{ACKNOWLEDGMENTS}

This work was supported by the Environmental Restoration Program of Los Alamos National Laboratory, as part of site characterization activities for the proposed Mixed Waste Disposal Facility and the Framework Studies of the Earth Science Technical Team. We thank Paul Aamodt, Bob Gillis, Darrell Bultman, Chuck Harrington, and Robert Raymond for their programatic support. D. Mann and Carlos Montoya prepared thin sections of these tuffs, many of which were difficult to mount and polish. S. Reneau, J. Wolff, and Robert Raymond provided critical reviews of this report. 


\section{REFERENCES}

Allard, B. and Beall, G. W., 1979, Sorption of Am on geologic media, J. of Environ. Sci. and Health, A14 (6). p. 507-518.

Allard, B., Olofsson U., Torstenfelt, B., Kipasti, H., and Anderson, H., 1982, Sorption of Actinides in well-defined oxidation states on geologic media, in Scientific Basis for Nuclear Waste Management V, Materials Research Society symposia Proceedings, L. Lutze, Ed. (Materials Research Society, Pittsburgh, Pennsylvania), p. 775-786.

Bailey, R. A., Smith, R. L., and Ross, C. S., 1969, Stratigraphic nomenclature of the volcanic rocks in the Jemez Mountains, New Mexico, U.S. Geol. Survey Bull. 1274-P, 19 p.

Beall, G. W. and Allard, B., 1981, Sorption of actinides from aqueous solutions under environmental conditions, in Proceedings of a Symposium on Adsorption from Aqueous Solutions, March 24-27, 1980, American Chemical Society Meeting, Division of Colloid and Surface Chemistry (Houston, TX), p. 193-212.

Bish, D. L. and Chipera, S. J., 1988, Problems and solutions in quantitative analysis of complex mixtures by X-ray powder diffraction, in Advances in X-Ray Analysis (Plenum Press, New York, 1988), v. 31, p. 295-308.

Bish, D. L. and Chipera, S. J., 1989, Revised mineralogic summary of Yucca Mountain, Nevada, Los Alamos National Laboratory report LA-11497-MS.

Brandberg, F. and Skagius, K., 1991, Porosity, sorption, and diffusivity data compiled for the SKB 91 Study, SKB-TR-91-16 Kaunbranslesakerhet, Stockholm.

Broxton, D. E. and Reneau, S.L., 1995, Stratigraphic Nomenclature of the Bandelier Tuff for Envi ronmental Restoration Project at Los Alamos National Laboratory: Los Alamos National Laboratory Report LA-13010-MS, Los Alamos, New Mexico, $21 \mathrm{p}$.

Broxton, D.E., Heiken, G., Chipera, S.J., and Byers, F.M., 1995, Stratigraphy, petrography, and mineralogy of Bandelier Tuff and Cerro Toledo deposits: in Broxton, D. E., and Eller, P. G., eds., Earth Science Investigations for Environmental Restoration--Los Alamos National Laboratory Technical Area 21: Los Alamos National Laboratory Report LA-12934-MS, Los Alamos, New Mexico, p. 33-63.

Chung, F. H., 1974a, Quantitative interpretation of X-ray diffraction patterns of mixtures. I. Matrixflushing method for quantitative multicomponent analysis, J. of App. Crystallography, v. 7, p. 519-525.

Chung, F. H., 1974b, Quantitative interpretation of X-ray diffraction pattems of mixtures. Il. Adiabatic principle of X-ray diffraction analysis of mixtures, J. of App. Crystallography, v. 7, p. 526531.

Compton, 1962, Manual of Field Geology, John Wiley and Sons, New York, 378 p.

Criss, J., 1980, Fundamental parameters calculations on a laboratory micrcomputer, Adv. X-Ray Analysis, v. 23, p. 93-97.

Crowe, B., Linn, G., Heiken, G., and Bevier, M., 1978, Stratigraphy of the Bandelier Tuff in the Pajarito Plateau, applications to waste management, Los Alamos National Laboratory report LA-7225-MS, $57 \mathrm{p}$.

Gardner, J. N., Kolbe, T., and Chang, S., 1993, Geology, drilling, and some hydrologic aspects of Seismic Hazards Program Core Holes, Los Alamos National Laboratory, New Mexico, Los Alamos National Laboratory Report LA-12460-MS, $19 \mathrm{p}$.

Goff, F., Heiken, G. H., Tamanyu, S., Gardener, J., Self, S., Drake, R., and Shafiqullah, M, 1984, Location of Toledo caldera and formation of the Toledo embayment, Jemez Mountains, New Mexico, EOS Trans., Amer. Geophys. Union, 65, p. 1145. 
Griggs, R. L., 1964, Geology and ground-water resources of the Los Alamos area, New Mexico, U.S. Geol. Survey Water-Supply Paper 1753, $107 \mathrm{p}$.

Grim, R. E., 1968, Clay Mineralogy, 2nd edition, McGraw-Hill Book Company, New York, 596 p.

Ho, C. H. and Miller, N. H., 1986, Adsorption of uranyl species from bicarbonate solution onto hematite particles, J. Colloid Interface Sci., v. 110, p. 165-171.

Hsi, C-K and Langmuir, 1985, Adsorption of uranyl onto ferric oxyhydroxides: Application of the surface complexation site-binding model, Geochim. Cosmochim. Acta, v. 49, p. 1931-1941.

Izett, G. A. and Obradovich, J. D., 1994, ${ }^{40} \mathrm{Ar} /{ }^{39} \mathrm{Ar}$ age constraints for the Jaramillo Normal Subchron and the Matuyama-Brunhes geomagnetic boundary, J. Geophys. Res. 99 (B2), p. 29252934.

Kolbe, T., Sawyer, J., Gorton, A., Olig, S., Simpson, D., Fenton, C., Reneau, S., Carney, J.; Bott, J., and Wong, I., 1994, Evaluation of the potential for surface faulting at the proposed Mixed Waste Disposal Facility, TA-67: unpublished report, Woodward-Clyde Federal Services, Oakland, California, 3 volumes.

Klug, H. P. and Alexander, L. E., 1974, X-Ray Diffraction Procedures for Polycrystalline and Amorphous Materials, John Wiley \& Sons, Inc, New York.

Meijer, A., 1992, Experiments and integration of relevant sorption models, Procs. of DOE/ Site Characterization Project Radionuclide Adsorption Workshop, Los Alamos National Laboratory, Sept. 11-12,1990, Los Alamos National Laboratory Conf. Report LA-12325-C, pp. 9-36.

Reneau, S. L., Kolbe, T. R., Simpson, D. T., Carney, J. S., Gardner, J. N., and Vaniman, D. T., 1995, Surficial materials and structure at Pajarito Mesa, Los Alamos National Laboratory, New Mexico, this report.

Self, S., Goff, F., Gardner, J. N., Wright, J. V., and Kite, W. M., 1986, Explosive rhyolitic volcanism in the Jemez Mountains: vent locations, caldera development, and relation to regional structure, J. Geophys. Res., v. 91, no. B2, p. 1779-1798.

Smith, R. L. and Bailey, 1966, The Bandelier Tuff: a study of ash-flow eruption cycles from zoned magma chambers, Bull. Volcanologique, v. 29, p. 83-104.

Smith, R. L., Bailey, R. A., and Ross, C. S., 1970, Geologic map of the Jemez Mountains, New Mexico, U.S. Geol. Survey Map 1-571, scale 1:1250000.

Smith, R. L., 1979, Ash flow magmatism, Geol. Soc. America Spec. Paper 180, p. 5-27.

Thomas, K. W., 1987, Summary of sorption measurements peiformed with Yucca Mountain, Nevada, tuff samples and water from well J-13, Los Alamos National Laboratory Report LA-10969MS.

Turin, H. J. and Rosenberg, N. D., 1993, Summary of TA-67 geology, hydrogeology, and seismicity for radiological performance assessment, unpublished report, Los Alamos National Laboratory, New Mexico.

Vaniman, D. T. and Wohletz, K., 1990, Results of geological/fracture studies: TA-55 area; Los Alamos National Laboratory, Geology/Geochemistry Group internal report, EES1-SH90$17,25 \mathrm{p}$.

Vaniman, D., and Wohletz, K., 1991, Revisions to report EES1-SH90-17: Unpub. Rept. EES1SH91-12, 2 p.

Vaniman, D., and Chipera, S., 1995, Mesa-penetrating fractures, fracture mineralogy, and projected fault traces at Pajarito Mesa, New Mexico, this report. 


\title{
SURFICIAL MATERIALS AND STRUCTURE AT PAJARITO MESA
}

\author{
by
}

\author{
Steven L. Reneau 1 , Thomas R. Kolbe 2 , David T. Simpson 3 , John S. Carney 1 , Jamie N. \\ Gardner ${ }^{1}$, Susan S. Olig ${ }^{2}$, and David T. Vaniman ${ }^{1}$ \\ 1 Geology and Geochemistry Group, Los Alamos National Laboratory \\ 2 Woodward-Clyde Federal Services, Oakland, California \\ 3 Woodward-Clyde Consultants, Oakland, California
}

\begin{abstract}
Geologic suiface mapping and exploratory trenching were conducted at Pajarito Mesa to evaluate the potential for surface faulting at the proposed Los Alamos National Laboratory Mixed Waste Disposal Facility (MWDF). Previous studies had indicated that southem extensions of the north-south trending Rendija Canyon and Guaje Mountain fault zones may cross Pajarito Mesa, near the site of the proposed MWDF, and that displacement had occurred on at least one and possibly both faults to the north during the last 11,000 years. Thus, an evaluation of their southern projections was required to evaluate whether the site met federal regulations pertaining to the siting of hazardous waste disposal facilities.

Exploratory trenches totaling $1340 \mathrm{~m}$ in length were excavated on Pajarito Mesa, exposing deposits that range in age from over 1 million years to less than 1000 years. Surficial deposits above the 1.2 million year old Bandelier Tuff include: (1) pumice-rich alluvium of early Pleistocene age that was deposited prior to incision of Pajarito Canyon; (2) buried soils up to $2 \mathrm{~m}$ in thickness that include welldeveloped argillic B horizons; (3) the ca. 50-60,000 year old El Cajete pumice; and (4) variably developed soils in deposits that range in age from at least 30,000 years to less than 1000 years. Variations in the thickness and characteristics of surficial materials along the length of the trenches provide evidence for temporal and spatial variations in surface erosion, and also for distinct periods of net deposition on the mesa top. Deposits both above and below the El Cajete pumice contain significant amounts of fine sand and silt, suggesting that substantial amounts of wind-blown sediment have been episodically deposited on the Pajarito Plateau; this eolian sediment may provide much of the fine-grained material incorporated into the mesa-top soils. The uppermost deposits also bury possible 10,000 to 11,000 year old fire pits and younger Anasazi archaeological sites that were excavated into the mesa-top soils, recording multiple periods of net surface deposition in the Holocene that may represent regional periods of accelerated wind erosion.
\end{abstract}

A variety of approaches was used to evaluate possible faulting on Pajarito Mesa, including: surface geologic mapping; detailed logging of stratigraphic contacts exposed within the trenches; surveying of a stratigraphic contact within the 
Bandelier Tuff; examination of variations in fracture characteristics both in the trenches and along cliffs; and an examination of mesa-top topographic profiles.

Faulting was recognized in the trenches only in the area of the early Pleistocene alluvium, $70 \mathrm{~m}$ east of the Rendija Canyon fault projection, where at least seven faults with a total of at least $1.2 \mathrm{~m}$ of down-to-the-west offset were exposed in a $20 \mathrm{~m}$ wide zone. A detailed survey of a stratigraphic contact in the Bandelier Tuff suggests a total of 7 to $9 \mathrm{~m}$ of down-to-the-west offset in a 100 to $200 \mathrm{~m}$ wide zone in the same area, with the alluvial deposits apparently preserved on downdropped blocks. The survey also provided evidence for several additional areas of faulting to the west. No offset of the buried soil beneath the El Cajete pumice was observed anywhere in the trenches, demonstrating the absence of faulting on this part of Pajarito Mesa for at least the last $50-60,000$ years; the site therefore meets regulatory requirements that facilities such as the proposed MWDF be located more than $60 \mathrm{~m}$ from Holocene faults. The absence of young faulting at this site indicates that the youngest surface ruptures that were previously documented on the Rendija Canyon and Guaje Mountain faults to the north terminated north of Pajarito Mesa or perhaps were transferred to other faults to the east or west.

Many uncertainties remain concerning the location, orientation, and timing of faulting at Pajarito Mesa, including the age of the most recent movement, due to the apparently dispersed nature of faulting on this part of the Pajarito Plateau and the common absence of well-defined stratigraphic contacts older than the $\mathrm{El}$ Cajete pumice. Fracture characteristics by themselves appear to be unreliable in defining the presence or absence of faulting at Pajarito Mesa, and the area of recognized faulting near the Rendija Canyon fault projection shows no increases in fracture density or fracture width either in the adjacent cliffs or within the trenches. In fact, this fault zone displays a relatively low fracture density in the trenches, and individual fractures that experienced movement are no wider than average. Variations in fracture density and fracture width at Pajarito Mesa may in part reflect variations in welding of the Bandelier Tuff, with wider fractures typically occurring in areas where the tuff is most welded, and the lowest fracture densities occurring where the tuff is nonwelded. However, the local concurrence of variations in the mesa-top topographic profile and relatively high fracture density and fracture width in the trenches suggests the possibility of Quaternary faulting in several areas, including part of the projected Guaje Mountain fault zone, although these inferences cannot be verified at present. 


\section{INTRODUCTION}

Pajarito Mesa is the candidate site for the proposed Los Alamos National Laboratory (LANL) Mixed Waste Disposal Facility (MWDF). Previous studies which examined subsurface data, aerial photograph lineaments, and bedrock fracture characteristics had suggested that southem extensions of the north-south trending Rendija Canyon and Guaje Mountain fault zones cross Pajarito Mesa (Fig. 1) (Dransfield and Gardner, 1985; Vaniman and Wohletz, 1990; Wong et al., 1995). At least one and perhaps both of these faults had Holocene surface rupture $(<11 \mathrm{ka}(\mathrm{ka}=1000$ years ago)) to the north (Gardner et al., 1990; Kelson et al., 1993; Wong et al., 1993, 1995), and an evaluation of their southern projections is thus critical for understanding potential surface rupture hazards to the MWDF.

Federal regulations pertaining to the citing of hazardous waste disposal facilities require that such facilities not be located within $200 \mathrm{ft}(61 \mathrm{~m})$ of faults displaying Holocene offset (40 CFR 264.18). They further require that if faults or lineaments are present within $3000 \mathrm{ft}(915 \mathrm{~m})$ of a proposed facility and if site analyses are otherwise inconclusive as to the exact location and age of faulting, then detailed subsurface exploration involving trenching is required (40 CFR 270.14). Surface geologic mapping and fracture studies at Pajarito Mesa were inconclusive as to the exact location and age of faulting (Vaniman and Chipera, this report). Thus, exploratory trenching activities were initiated.

Exploratory trenches totaling $1340 \mathrm{~m}$ in length were excavated on Pajarito Mesa in the summer and fall of 1993 (Figs. 1 and 2), and detailed geologic logs of the trench walls were prepared (Kolbe et al., 1994). The trenches were sited to include both the proposed MWDF disposal pits and the southern projections of the Rendija Canyon and Guaje Mountain fault zones, as mapped by Vaniman and Wohletz (1990) and Wong et al. (1995), to more thoroughly evaluate the history of faulting on Pajarito Mesa. The trenches were excavated deep enough to expose 0.5 to $1.0 \mathrm{~m}$ of intact Bandelier Tuff bedrock beneath the surficial deposits, where possible, and they ranged in depth from 1.5 to $4 \mathrm{~m}$. In addition to the constraints they provided for faulting, the trench exposures displayed a unique cross section of mesa-top soils in the central part of LANL. These exposures provided an opportunity to examine the characteristics and variability of surficial materials on a relatively undisturbed mesa, and to evaluate the mesa-top history of erosion, deposition, and soil development.

This report summarizes the characteristics of surficial materials and the structure of Pajarito Mesa, as determined in the trench exposures (Kolbe et al., 1994) and from complementary surface studies. Data from similar trenching activities on a nearby mesa in the TA-63 area, $1 \mathrm{~km}$ north of Pajarito Mesa, (Fig. 1; Kolbe et al., 1995) are also discussed as they pertain to evaluating faulting and surficial materials. Finally, some interpretations of the characteristics of faulting in the central part of LANL are made based on these studies and on other work in the area.

\section{SETTING}

Pajarito Mesa is a roughly east-west trending mesa bounded by Pajarito Canyon to the north and Threemile Canyon to the south (Fig. 1). The mesa top elevation at the trenches decreases from $7300 \mathrm{ft}(2226 \mathrm{~m})$ at the west to $7180 \mathrm{ft}(2189 \mathrm{~m})$ at the east. The width of the mesa varies from about 200 to $400 \mathrm{~m}$ at the trenches, being narrowest to the east adjacent to a small tributary canyon of Threemile Canyon. The trenches are.all located within $40 \mathrm{~m}$ of the mesa-top drainage divide, typically within less than $15 \mathrm{~m}$. The mesa-top gradient averages about $3 \%\left(1.7^{\circ}\right.$ slope), although it shows significant local variations (Fig. 3). The western and eastern trenches are located on relatively gentle parts of Pajarito Mesa, with average gradients of about $2.3 \%$ and $2.1 \%$ (1.3 and $\left.1.2^{\circ}\right)$, respectively, with a steeper area in between that averages about $4.6 \%\left(2.6^{\circ}\right)$. 


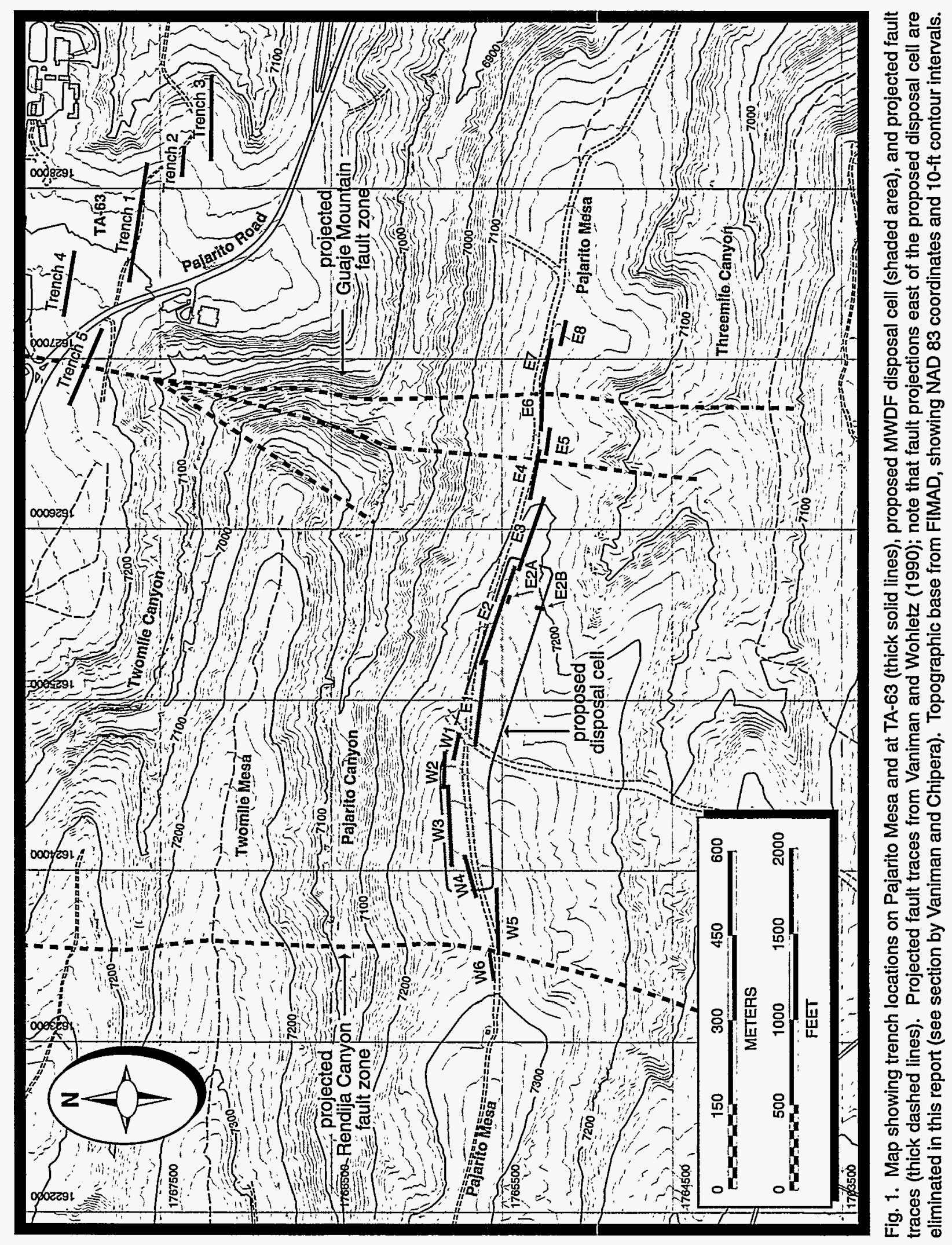




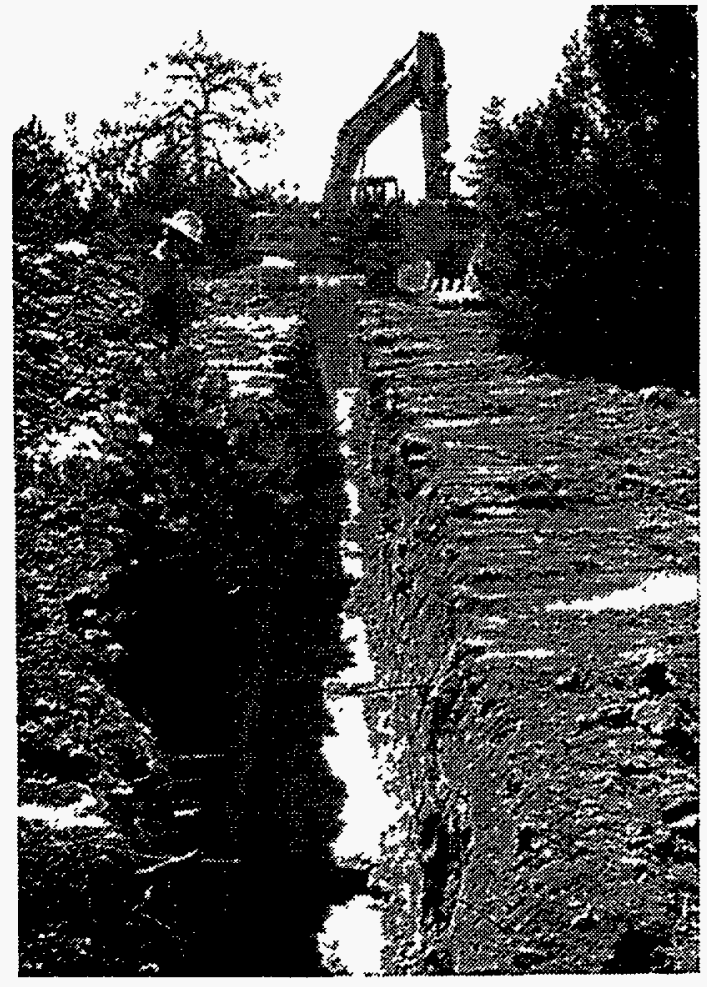

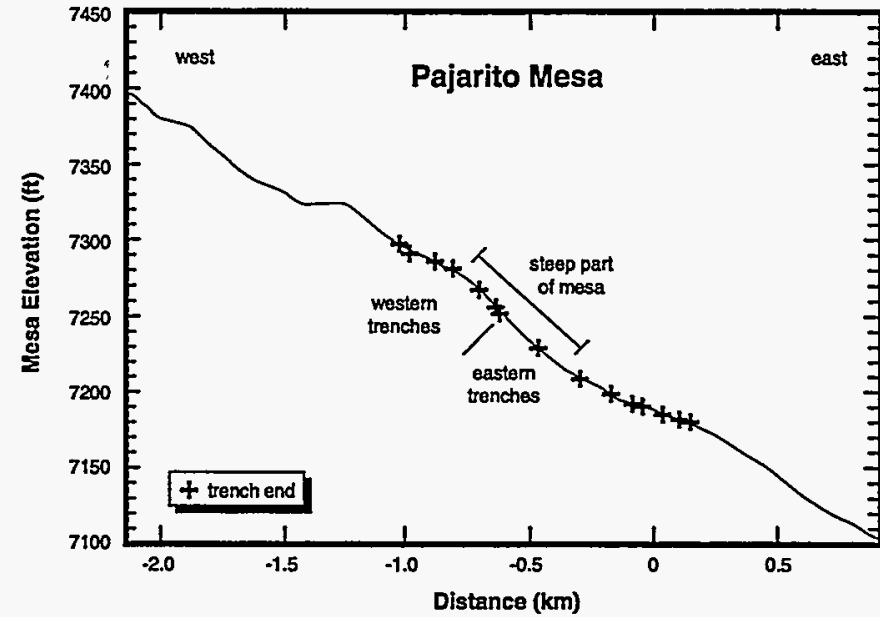

Fig. 3. Longitudinal topographic profile of Pajarito Mesa. Crosses indicate location of end-points of each trench. Profile trends N85W, with the topographic crest of the mesa projected to the profile line. Topography from FIMAD maps with 2-ft contour intervals. Distance is relative to the confluence of Pajarito and Twomile Canyons.

Fig. 2. Photograph of trench during excavation.

Bedrock at Pajarito Mesa consists of several units of the Tshirege Member of the Bandelier Tuff that were erupted from the Jemez Mountains about 1.22 Ma (million years ago) (Izett and Obradovich, 1994). Tshirege Member unit 4 is exposed in trenches W1 to W6 and part of E1, and the underlying unit 3 is exposed in the eastern trenches (bedrock units from Vaniman and Wohletz, 1990, and Broxton et al., this report). Units 3 and 4 are separated by volcanic surge beds which are best exposed on Pajarito Mesa to the south of the mesa-top drainage divide. The surge beds are also exposed in trench $\mathrm{E} 1$ at the base of unit 4, and are present over short distances in trenches E2 and E6 as clasts within a basal soil layer that is composed largely of disrupted tuff.

The climate at Pajarito Mesa is semi-arid, with estimated average annual precipitation of about $43 \mathrm{~cm}$ (17 in.). About $40 \%$ of the precipitation occurs in July and August during summer thunderstorms. Average annual snowfall is about $125 \mathrm{~cm}$ (50 in.) (Bowen, 1990). The vegetation is dominated by Ponderosa pine forest to the west, west of trench $\mathrm{E} 1$, and piñon-juniper woodland to the east.

\section{SURFICIAL MATERIALS}

Surficial deposits that range in age from early Quaternary (>1 Ma?) to latest Holocene (< $1 \mathrm{ka}$ ) overlie the Tshirege Member of the Bandelier Tuff in the Pajarito Mesa trenches. The stratigraphic units as logged by Kolbe et al. (1994) are shown schematically in Fig. 4. Units 5a, 5c, and $5 \mathrm{~b}$ of Kolbe et al. (Fig. 4) correspond to Tshirege Member unit 4, unit 3, and the intervening surge beds, respectively. Units $4 \mathrm{a}$ to $4 \mathrm{f}$ of Fig. 4 includes early Quaternary alluvium and associated pumice beds. Units $3 a$ to $3 e$ are divisions of soils that underlie the ca. 50-60 ka El Cajete pumice. Unit $2 \mathrm{c}$ is undisturbed El Cajete pumice, unit $2 \mathrm{~b}$ is disrupted (bioturbated) El Cajete pumice, and unit $2 a$ is a soil $B$ horizon that is developed within the disrupted pumice and in overlying deposits. 


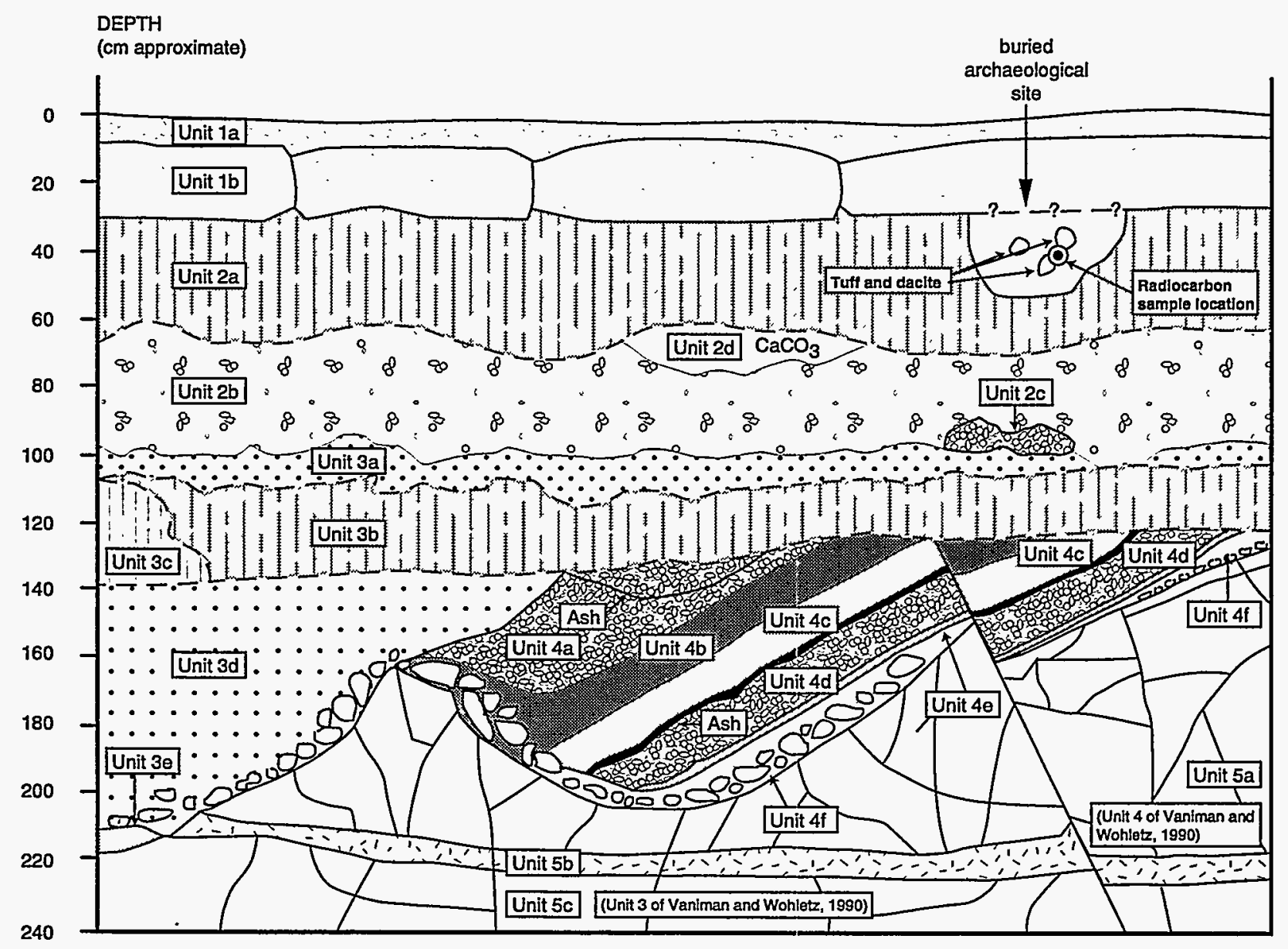

Fig. 4. Schematic composite log showing relations of units exposed in Pajarito Mesa trenches, modified from Kolbe et al. (1994). Unit designations discussed in text.

Units 1a and 1b of Kolbe et al. (1994) are the uppermost units at Pajarito Mesa, and are locally associated with or overlie buried archaeological sites. The soil units at Pajarito Mesa (units 1 to 3 of Fig. 4) display significant lateral variability in thickness and degree of soil development, as discussed below.

\section{Radiocarbon Age Control}

Age control for the soil units younger than the El Cajete pumice is provided by radiocarbon dating of charcoal contained within these units. Radiocarbon dates in this study were converted to calibrated calendar ages using the computer program of Stuiver and Reimer (1993) to correct for the effects of fluctuations in the ${ }^{14} \mathrm{C} /{ }^{12} \mathrm{C}$ ratio in the atmosphere. Calibrated ages are most useful when comparing radiocarbon ages with ages obtained from other methods, such as archaeological sites dated by dendrochronology. As part of the calibration, corrections to the reported ${ }^{14} \mathrm{C}$ dates were made for isotope fractionation (if this correction was not made by the dating laboratory), and an "error multiplier" was used to account for possible sources of laboratory error that were not included in the reported uncertainties. The correction for isotope fractionation used in this report assumes an average $\delta^{13} \mathrm{C}$ value of $-23.7 \pm 1.3 \%$ based on analyses of 57 samples from the Pajarito Plateau. Eighteen analyses from Pajarito Mesa (Tables 1 and 2), included within the larger data set, provide a similar average $\delta^{13} \mathrm{C}$ value of $-24.2 \pm 0.8 \%$. 
TABLE 1. Radiocarbon Dates For El Cajete Pumice and Related Units

\begin{tabular}{|c|c|c|c|c|c|}
\hline Field Number & Laboratory Number * & $\begin{array}{c}{ }^{14} \text { C Date } \\
\text { (yr B.P.) }\end{array}$ & $\begin{array}{c}\delta^{13} \mathrm{C} \\
(\% \circ)\end{array}$ & $\begin{array}{l}\text { Pretreated } \\
\text { Sample } \\
\text { Weight } \\
\text { (g or } \mathrm{mg} \text { ) }\end{array}$ & Ref $* \star$ \\
\hline \multicolumn{6}{|c|}{ Samples from El Cajete Pumice, Jemez Mountains } \\
\hline $\begin{array}{l}- \\
R P-1 \\
R P-25 \\
R P-47 \\
R P-51 \\
R P-47 \\
R P-47 c\end{array}$ & $\begin{array}{c}\text { W-1553 } \\
\text { QL-4629 } \\
\text { QL-4645 } \\
\text { QL-4727 } \\
\text { QL-4728 } \\
\text { Beta-68851/CAMS-10505 } \\
\text { Beta-70684/CAMS-11759 }\end{array}$ & $\begin{array}{c}>42,000 \\
>58,000 \\
50,100 \pm 1300 \# \\
57,200+4100 /-2700 \\
>54,100 \\
26,370 \pm 270 \# \\
>47,640\end{array}$ & $\begin{array}{l}- \\
-22.3 \\
-22.1 \\
-21.7 \\
-22.1 \\
-23.9 \\
-22.4\end{array}$ & $\begin{array}{c}- \\
16.5 \mathrm{~g} \\
17.2 \mathrm{~g} \\
19.2 \mathrm{~g} \\
19.8 \mathrm{~g} \\
0.7 \mathrm{mg} \\
10.7 \mathrm{mg}\end{array}$ & $\begin{array}{l}1 \\
2 \\
2 \\
2 \\
2 \\
2 \\
2\end{array}$ \\
\hline \multicolumn{6}{|c|}{ Samples from underlying stratigraphic units, Pajarito Plateau } \\
\hline $\begin{array}{l}\text { WTT1-1D } \\
\text { WTT1-5 } \\
\text { WTT2-1 } \\
\text { E3 RCS } 5 \\
\text { E7 RCS } 1 \\
\text { E8 RCS 2 }\end{array}$ & $\begin{array}{c}\text { Beta-55313/CAMS-3715 } \\
\text { TO-3413 } \\
\text { Beta-60220 } \\
\text { Beta-68838 } \\
\text { Beta-68839/CAMS-10497 } \\
\text { Beta-68841/CAMS-10498 } \\
\end{array}$ & $\begin{array}{c}>47,500 \\
19,070 \pm 160 \# \\
22,420 \pm 690 \# \\
>46,570 \\
10,030 \pm 50 \# \\
>45,400\end{array}$ & $\begin{array}{c}-24.0 \\
- \\
- \\
- \\
-23.0 \\
-23.7 \\
\end{array}$ & $\begin{array}{c}66.8 \mathrm{mg} \\
37.0 \mathrm{mg} \\
350 \mathrm{mg} \\
4.4 \mathrm{~g} \\
286.5 \mathrm{mg} \\
2.9 \mathrm{mg} \\
\end{array}$ & $\begin{array}{l}3 \\
3 \\
3 \\
4 \\
4 \\
4 \\
\end{array}$ \\
\hline
\end{tabular}

" Laboratory designation: Beta = Beta Analytic Inc., Miami, Florida; CAMS = Lawrence Livermore National Laboratory, Livermore, California; $Q \mathrm{~L}=$ Quaternary Isotope Laboratory, Seattle, Washington; TO = IsoTrace Radiocarbon Laboratory, Toronto; W = U. S. Geological Survey, Reston, Virginia. ${ }^{* \star}$ References: 1 = Bailey et al., 1969; $2=S$. L. Reneau and J. N. Gardner, previously unpublished data $3=$ Wong et al., 1995; $4=$ Kolbe et al., 1994.

\# Date believed to be too young due to contamination of sample or of stratigraphic unit with young carbon.

Inclusion of an "error multiplier" in the calibration of radiocarbon dates is recommended by some radiocarbon dating laboratories to incorporate uncertainties not included in the reported laboratory uncertainty (e.g., Stuiver and Reimer, 1993). The uncertainties in ${ }^{14} \mathrm{C}$ dates reported by the analytical laboratories (Tables 1 and 2 ) are based solely on counting statistics and may not accurately reflect the ability of a single lab or multiple labs to reproduce a ${ }^{14} \mathrm{C}$ age on a single sample. A recent international interlaboratory comparison indicated that an error multiplier of about 2 was typical for laboratories that participated in the study (Scott et al., 1990), and an error multiplier of 2 is therefore used in this study, although the study of Scott et al. (1990) showed that even this relatively conservative value may not encompass all sources of laboratory error. Although there is not yet a consensus on the most appropriate error multiplier, other recent studies have similarly chosen a value of 2 (e.g., Nelson, 1992, Plafker et al., 1992).

\section{Mesa-Top Alluvium}

Deposits of stratified pumice-rich alluvium, consolidated fluvial sand beds, and thin ash layers (unit 4 of Fig. 4) were exposed in trenches W3, W4, and W5, immediately overlying Tshirege Member unit 4 . The pumice beds (units $4 \mathrm{a}$ and $4 \mathrm{~d}$ of Fig. 4) are often pure, and may in part represent fluvial reworking of fallout deposits soon after their eruption. Scattered rounded cobbles of Tschicoma Formation dacite are present in the sand beds, particularly in the trench W3 deposits. These alluvial deposits are up to at least $1.4 \mathrm{~m}$ thick, but their tops have been eroded and the original thickness is thus unknown. The alluvial layers in trench W5 dip $5^{\circ}$ to $20^{\circ}$ to the east, much steeper than the mesa top or Bandelier Tuff stratigraphic contacts $\left(1^{\circ}\right.$ to $\left.3^{\circ}\right)$, suggesting that they have been tectonically tilted. Erosional unconformities also exist within the alluvium, and east of the $33 \mathrm{~m}$ point in trench W5 units $4 \mathrm{c}$ to $4 \mathrm{f}$ had been eroded prior to deposition of unit $4 \mathrm{~b}$ (Fig. 5). 
TABLE 2. Radiocarbon Dates From Post El Cajete Units, Pajarito Mesa

\begin{tabular}{|c|c|c|c|c|c|c|c|}
\hline $\begin{array}{l}\text { Field } \\
\text { Number }\end{array}$ & $\begin{array}{l}\text { Laboratory } \\
\text { Number * }\end{array}$ & $\begin{array}{l}{ }^{14} \mathrm{C} \text { Date } \\
\text { (yr B.P.) }\end{array}$ & $\begin{array}{c}\delta^{13} \mathrm{C} \\
(\% \circ)\end{array}$ & Calibrated Age *** & $\begin{array}{c}\text { Pretreated } \\
\text { Sample } \\
\text { Weight } \\
\text { (g or } \mathrm{mg} \text { ) }\end{array}$ & $\begin{array}{l}\text { Depth } \\
(\mathrm{m})\end{array}$ & $\begin{array}{c}\text { Trench } \\
\text { Locatio } \\
n \\
(m)\end{array}$ \\
\hline \multicolumn{8}{|l|}{ Unit 1b Soils } \\
\hline $\begin{array}{l}\text { E1 RCS1a-b } \\
\text { W3 RCS1a-d }\end{array}$ & $\begin{array}{l}\text { Beta-69121 } \\
\text { Beta-69123 }\end{array}$ & $\begin{array}{l}\text { modern } \\
\quad 70 \pm 90\end{array}$ & $\begin{array}{l}-24.9 \\
-23.6\end{array}$ & $\begin{array}{c}\text { post-1955 A.D. \# } \\
\text { 0\# cal BP }(0-500 \text { \#) } \\
1955 \text { \# cal AD }(1450-1955 \#)\end{array}$ & $\begin{array}{l}0.32 \mathrm{~g} \\
0.37 \mathrm{~g}\end{array}$ & $\begin{array}{l}0.15 \\
0.18\end{array}$ & $\begin{array}{l}17-27 \\
143\end{array}$ \\
\hline E3 RCS4 & $\begin{array}{l}\text { Beta-68837 } \\
\text { CAMS-10496 }\end{array}$ & $540 \pm 60$ & -23.9 & $\begin{array}{c}540 \mathrm{cal} \mathrm{BP}(310-680) \\
1410 \mathrm{cal} \mathrm{AD}(1270-1640)\end{array}$ & $14.2 \mathrm{mg}$ & 0.22 & 142 \\
\hline E5 RCS3 & $\begin{array}{l}\text { Beta-72977 } \\
\text { CAMS-13705 }\end{array}$ & $600 \pm 60$ & -23.5 & $\begin{array}{c}620-560 \mathrm{cal} \mathrm{BP}(330-730) \\
1330-1400 \mathrm{cal} \text { AD }(1220-1620)\end{array}$ & $114.6 \mathrm{mg}$ & 0.14 & 25 \\
\hline W2 RCS3a-c & $\begin{array}{l}\text { Beta-69122 } \\
\text { CAMS-10753 }\end{array}$ & $710 \pm 50$ & -23.4 & $\begin{array}{c}660 \mathrm{cal} \mathrm{BP}(520-780) \\
1290 \mathrm{cal} \mathrm{AD}(1160-1430)\end{array}$ & $263.4 \mathrm{mg}$ & 0.18 & $54-61$ \\
\hline \multicolumn{8}{|c|}{ Potential Archaeological Sites } \\
\hline W4 RCS5 & Beta-70683 & $420 \pm 70$ & $\star \star *$ & $\begin{array}{c}500 \text { cal BP }(660-0 \#) \\
1450 \text { cal } A D(1290-1954)\end{array}$ & $3.2 \mathrm{~g}$ & 0.35 & 28 \\
\hline E8 RCS1 & Beta-68840 & $760 \pm 50$ & ** & $\begin{array}{c}680 \mathrm{cal} \mathrm{BP}(550-920) \\
1280 \mathrm{cal} \mathrm{AD}(1030-1400)\end{array}$ & $1.8 \mathrm{~g}$ & 0.5 & 7 \\
\hline W4 RCS1 & $\begin{array}{l}\text { Beta-68844 } \\
\text { ETH-11894 }\end{array}$ & $895 \pm 55$ & -23.7 & $\begin{array}{l}784 \text { cal BP }(651-1051) \\
1166 \text { cal AD }(899-1299)\end{array}$ & $481 \mathrm{mg}$ & 0.8 & 6 \\
\hline W4 RCS3a & Beta-70682 & $920 \pm 50$ & ** & $\begin{array}{c}900-800 \mathrm{cal} \mathrm{BP}(1060-670) \\
1050-1150 \mathrm{cal} \mathrm{AD}(900-1290)\end{array}$ & $13.9 \mathrm{~g}$ & 0.8 & 17 \\
\hline W4 RCS4 & Beta-68846 & $970 \pm 70$ & ** & $\begin{array}{c}930 \mathrm{cal} \mathrm{BP}(660-1230) \\
1030 \mathrm{cal} \text { AD }(720-1290)\end{array}$ & $1.1 \mathrm{~g}$ & 0.35 & 57 \\
\hline W4 RCS6 & Beta-72978 & $1020 \pm 70$ & ** & $\begin{array}{c}940 \mathrm{cal} \mathrm{BP}(1270-670) \\
1010 \mathrm{cal} \mathrm{AD}(680-1280)\end{array}$ & $1.6 \mathrm{~g}$ & 0.5 & 16 \\
\hline W5 RCS1 & Beta-72979 & $2750 \pm 70$ & ** & $\begin{array}{r}2860 \text { cal BP (3260-2500) } \\
900 \mathrm{cal} \mathrm{BC}(1310-550)\end{array}$ & $2.0 \mathrm{~g}$ & 0.4 & 84 \\
\hline W3 RCS4 & $\begin{array}{l}\text { Beta-69124 } \\
\text { CAMS-10754 }\end{array}$ & $8770 \pm 50$ & -24.9 & $\begin{array}{l}9840-9680 \text { cal BP(9980-9490) } \\
7890-7740 \text { cal BC }(8030-7540)\end{array}$ & $31.1 \mathrm{~g}$ & 0.34 & 144 \\
\hline E5 RCS2a & $\begin{array}{l}\text { Beta-72976 } \\
\text { CAMS-13704 }\end{array}$ & $9270 \pm 50$ & -25.2 & $\begin{array}{c}10290-10210 \text { cal BP }(10540-10010) \\
8340-8270 \text { cal BC }(8590-8060)\end{array}$ & $24.2 \mathrm{mg}$ & 0.4 & 51 \\
\hline E1 RCS2 & $\begin{array}{l}\text { Beta-68833 } \\
\text { CAMS-13704 }\end{array}$ & $9490 \pm 90$ & ** & $\begin{array}{c}10490-10770 \mathrm{cal} \mathrm{BP}(10040-11000) \\
8540-8820 \mathrm{cal} \mathrm{BC}(9050-8090)\end{array}$ & $1.4 \mathrm{~g}$ & 0.46 & 92 \\
\hline E1 RCS2a & $\begin{array}{l}\text { Beta-70681 } \\
\text { CAMS-11758 }\end{array}$ & $9470 \pm 60$ & -23.9 & $\begin{array}{c}10470 \text { cal BP }(10960-10150) \\
8520 \text { cal BC }(9000-8200)\end{array}$ & $61.1 \mathrm{mg}$ & 0.46 & 92 \\
\hline
\end{tabular}



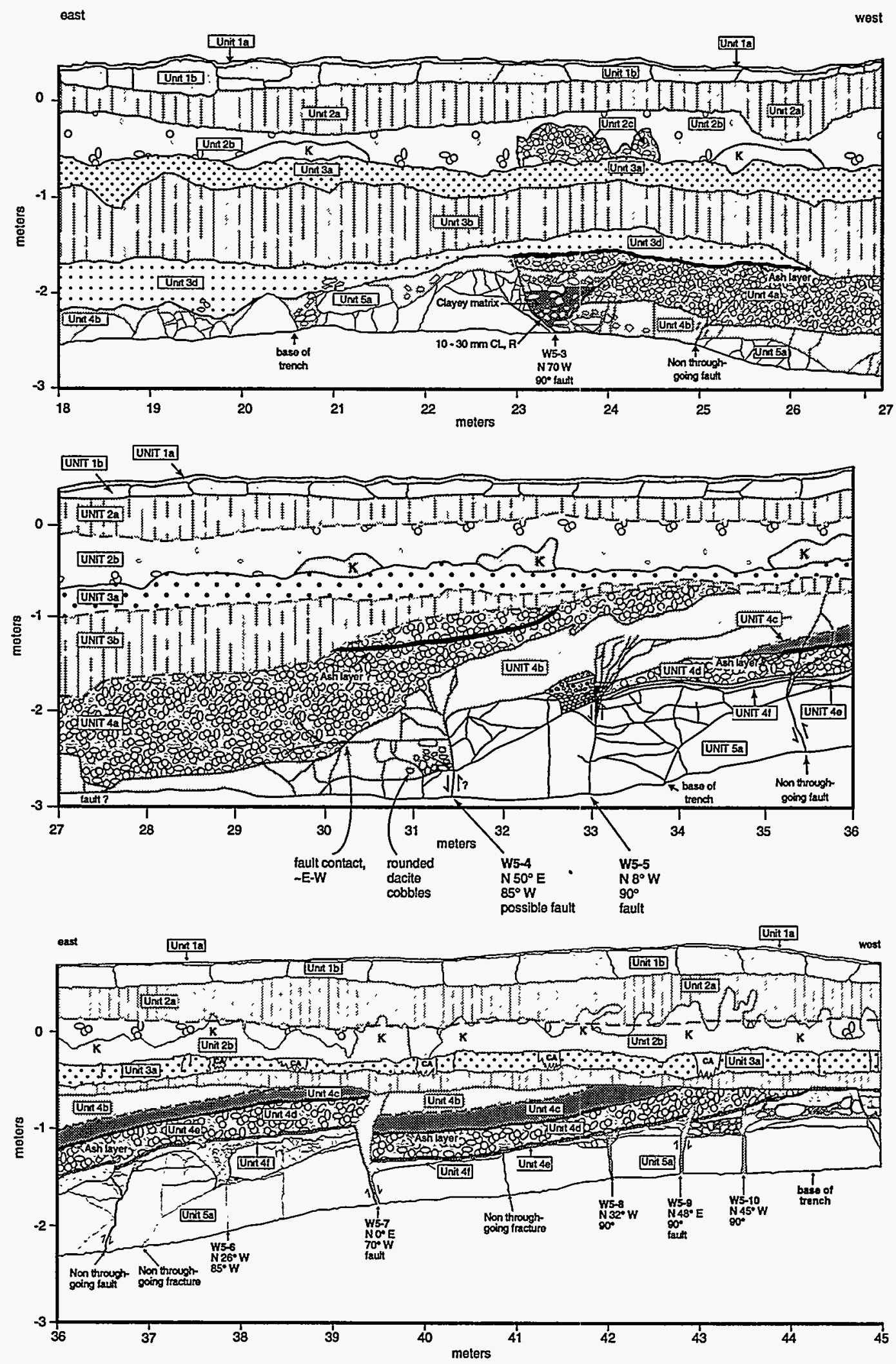

Fig. 5. Log of part of trench W5 from 18 to $45 \mathrm{~m}$, showing alluvial stratigraphy and faults." $\mathrm{K}$ " indicates krotovina (animal burrow or root hole). Modified from Kolbe et al., 1994. 
A paleochannel trending N75W was clearly exposed in trench $\mathrm{W} 3$, and other paleochannels trending obliquely to trenches W4 and W5 were recognized by contrasting stratigraphy between the opposite trench walls (Fig. 6). The paleochannels in trenches W4 and W5 have similar estimated orientations of $\mathrm{N} 80 \mathrm{~W} \pm 10^{\circ}$ and $\mathrm{N} 60 \mathrm{~W} \pm 30^{\circ}$, respectively (Fig. 7).

The pumices in the alluvium are part of a series of pre-El Cajete, post-Bandelier pumice fall deposits that have been recently recognized at other locations on the Pajarito Plateau. These pumices may have originated from eruptions in the Valles caldera that closely post-dated caldera formation. $A{ }^{40} \mathrm{Ar} /{ }^{39} \mathrm{Ar}$ date of $1.25 \pm 0.01 \mathrm{Ma}$ from pumices overlying the Bandelier Tuff near the Guaje Pines Cemetery, $6 \mathrm{~km}$ north of Pajarito Mesa (Laughlin et al., 1993), is very similar to a revised ${ }^{40} \mathrm{Ar} /{ }^{39} \mathrm{Ar}$ date of $1.22 \pm 0.02 \mathrm{Ma}$ for the Tshirege Member of the Bandelier Tuff (Izett and Obradovich, 1994), and supports this interpretation. The mineralogy and chemical composition of the Pajarito Mesa pumices indicate that they represent several different eruptions, and stratigraphic relations elsewhere on the Pajarito Plateau indicate that the pumice beds at Pajarito Mesa are younger than the dated Guaje Pines beds (D. E. Broxton, personnel communication, 1994), although the range in age of the pumices is presently unknown. Because of the local abundance of the pumice in the alluvium, the alluvium is believed to be similar in age to the pumice and probably older than $1 \mathrm{Ma}$.

Patches of stream-rounded cobbles and boulders also occur along both the north and south sides of Pajarito Mesa (Qoal; Fig. 7). The clasts range up to at least $0.9 \mathrm{~m}$ in size and are primarily composed of Tschicoma Formation dacite, derived from the Sierra de los Valles, and a small percentage (about $5 \%$ ) of Bandelier Tuff. Similar gravels are now being deposited only in the major canyons, such as Pajarito Canyon, that originate in the Sierra de los Valles. The dacite gravels occur both on top of Tshirege Member unit 4 to the west, and on top of the resistant part of unit 3 to the east, at a height of 60 to $75 \mathrm{~m}$ above the bottom of Pajarito Canyon. The gravels are typically found on the sloping edges of the mesa, resting on Bandelier Tuff bedrock (Figs. 7 and 8 ).

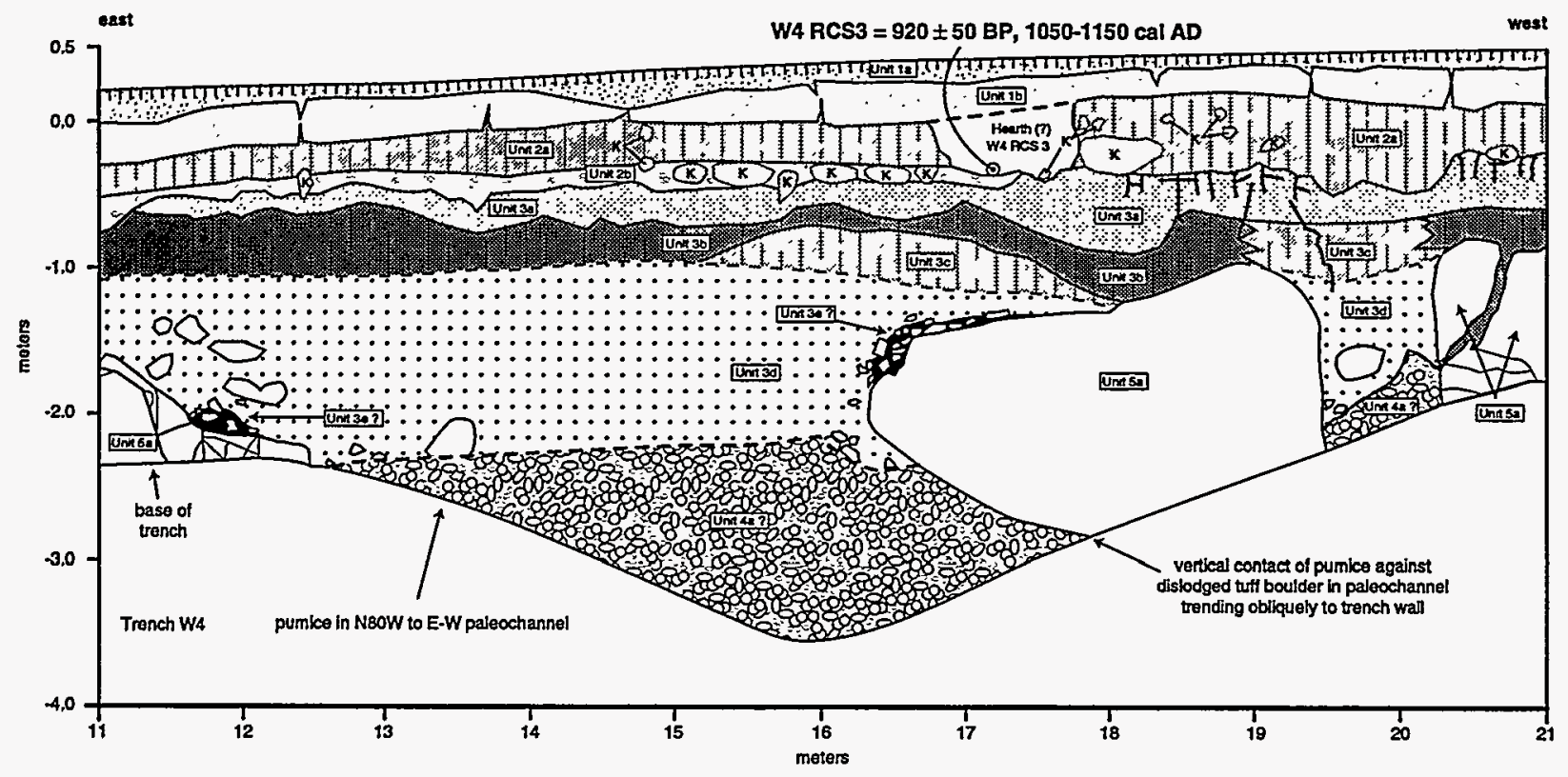

Fig. 6. Log of part of trench W4, showing eariy Quaternary pumice-rich alluvium (unit 4a?) within a paleochannel. The unit 5a (Tshirege Member unit 4) block at 16.5 to $19.5 \mathrm{~m}$ apparently partially collapsed from the west wall of the paleochannel. The eastern contact of this block with the unit 4 a pumice trends N80W. Also shown in this sketch is the W4 RCS3 sample site, an inferred archaeological site that contained charcoal dated at 1050 to 1150 A.D. "K" indicates krotovina (animanl burrow or root hole). Modified from Kolbe et al. (1994). 


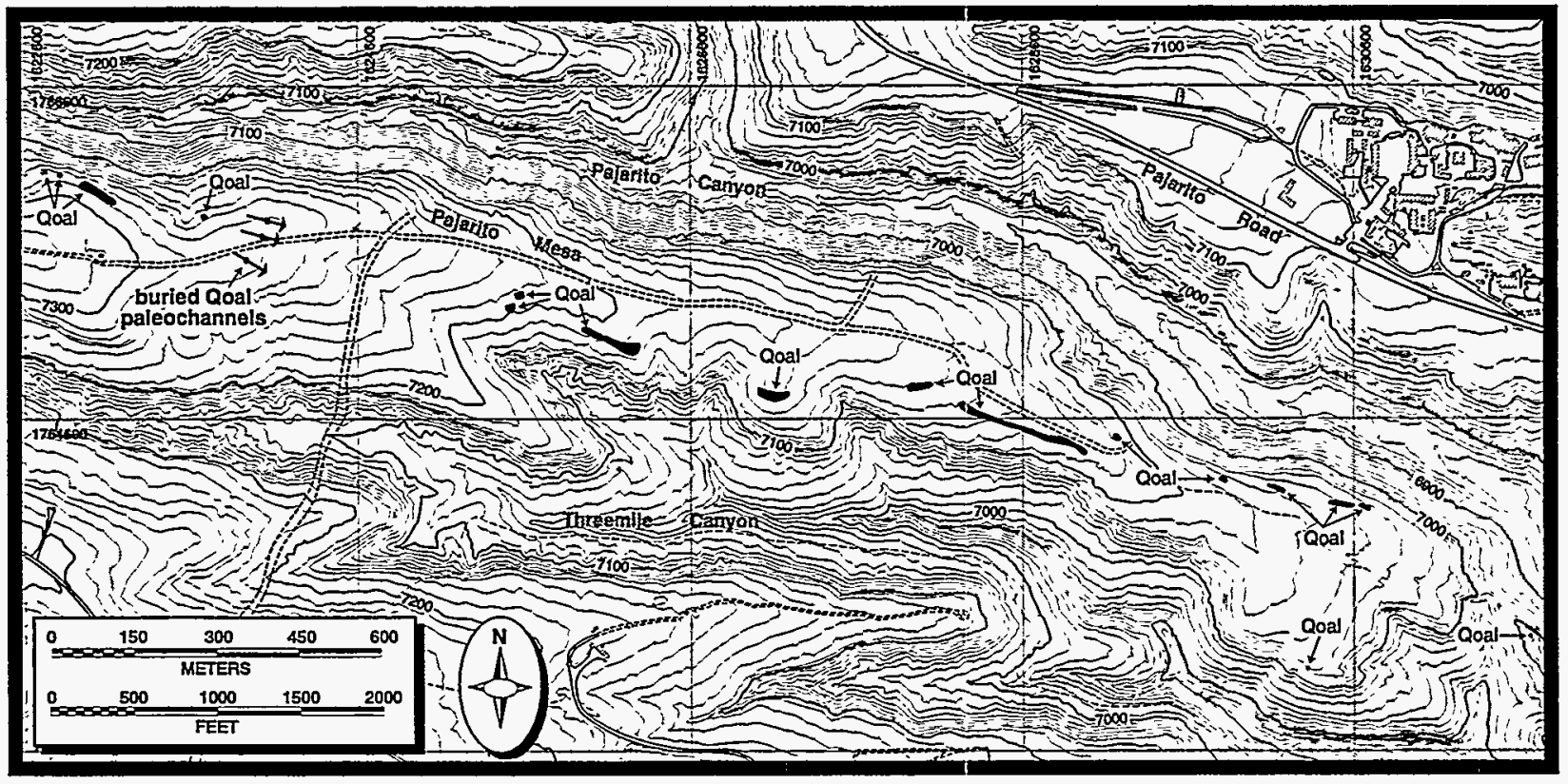

Fig. 7. Map showing location of mesa-top alluvial gravels on Pajarito Mesa (black areas labeled Qoal) and estimated orientations of paleochannels (arrows) exposed in trenches W3, W4, and W5. Topographic base from FIMAD, showing NAD 83 coordinates and 10-ft contour intervals.

The thickness of these deposits was not determined, but may range up to $0.5 \mathrm{~m}$ or more. It is notable that the gravel patches are aligned along a general trend of about N70W to $\mathrm{N} 75 \mathrm{~W}$ that is similar to the orientations of the paleochannels which were exposed in trenches W3, W4, and W5. This similarity suggests that most of the gravel patches may record the location of a discrete paleochannel or closely-spaced paleochannels.

The absence of rounded dacite gravels in most of the trenches was unexpected, given their abundance on the mesa edges, and a short exploratory trench (trench E2B, Fig. 1) was excavated through one of the gravel patches to investigate their stratigraphic context. The dacite clasts exposed in trench E2B are scattered within both a lower clay-rich soil and an unconformably overlying upper soil that is correlative with the Holocene soils exposed in the main trenches (Fig. 9). Notably, the highest concentration of dacite clasts observed in this trench occur within the upper soil, and supports the interpretation that they represent a lag deposit left after extensive erosion of an older alluvial deposit.

The dacite-bearing alluvial deposits on Pajarito Mesa are interpreted as deposits from the Pajarito Canyon drainage basin that pre-date incision of the canyon on this part of the Pajarito Plateau, during which time stream channels spread out over the top of the Bandelier Tuff. A source in the present Pajarito Canyon basin is inferred from the mapped distribution of these gravels, with their western outcrops on the north side of Pajarito Mesa, adjacent to the rim of Pajarito Canyon. A source in the Pajarito Canyon basin is also suggested by the paleochannel orientations of N60W to N80W in trenches W3, W4, and W5 (Fig. 7). Abandonment of the old stream channels probably resulted from the headward erosion of Pajarito Canyon from its mouth at the Rio Grande, consolidating a diffuse drainage system, as interpreted for Los Alamos Canyon (Reneau, 1995).

Alluvial deposits and associated lag gravels similar to those present at Pajarito Mesa are widespread on the western Pajarito Plateau. Other localities include DP Mesa (Reneau, 1995), the Los Alamos County landfill (Wong et al., 1995), Los Alamos townsite (S. Reneau and J. Gardner, unpublished data), and Twomile Mesa (Longmire et al., 1995). Alluvial gravels have also been 


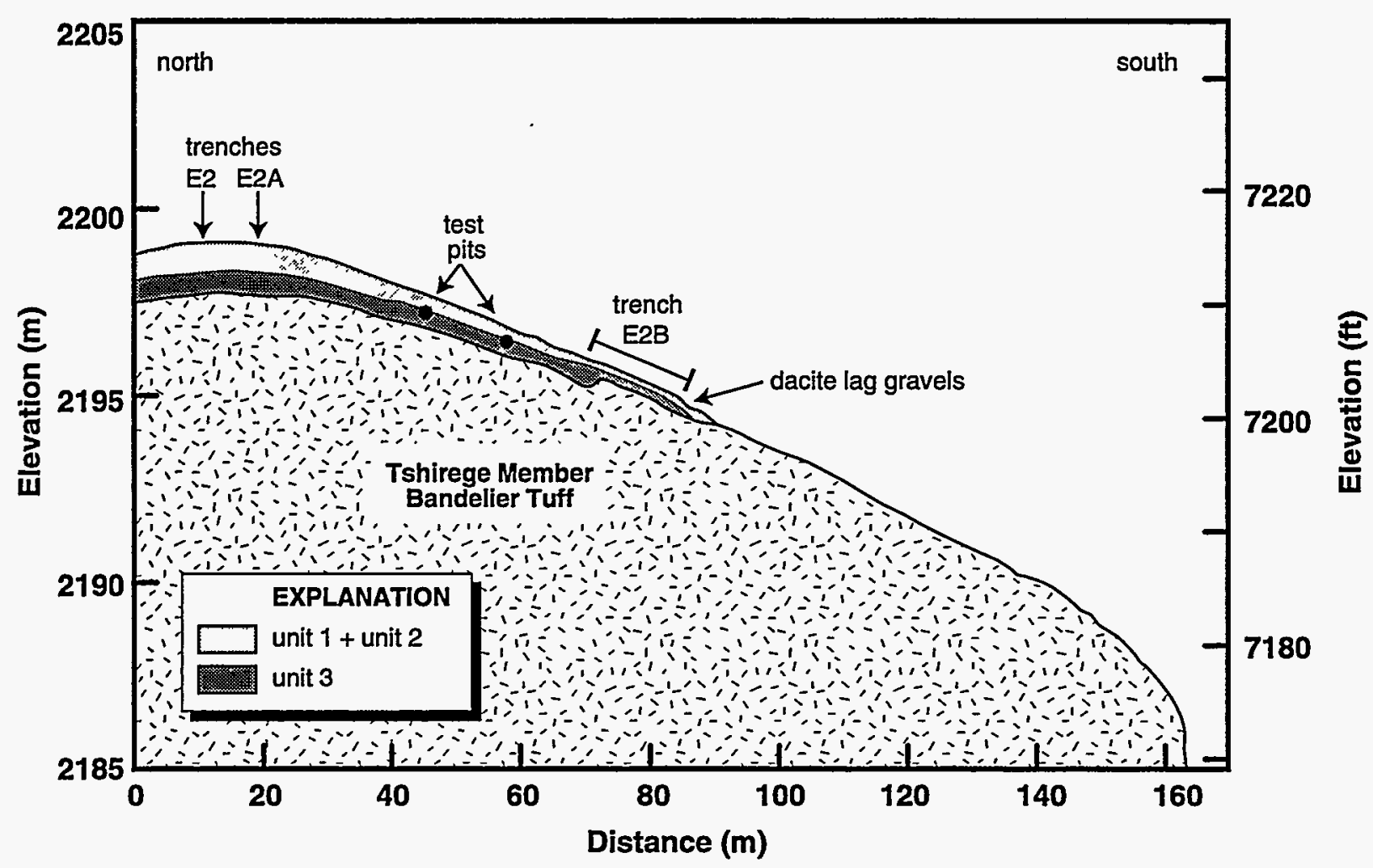

Fig. 8. North-south cross section across south side of Pajarito Mesa at trenches E2, E2A, and E2B, showing general variations in soil thickness.

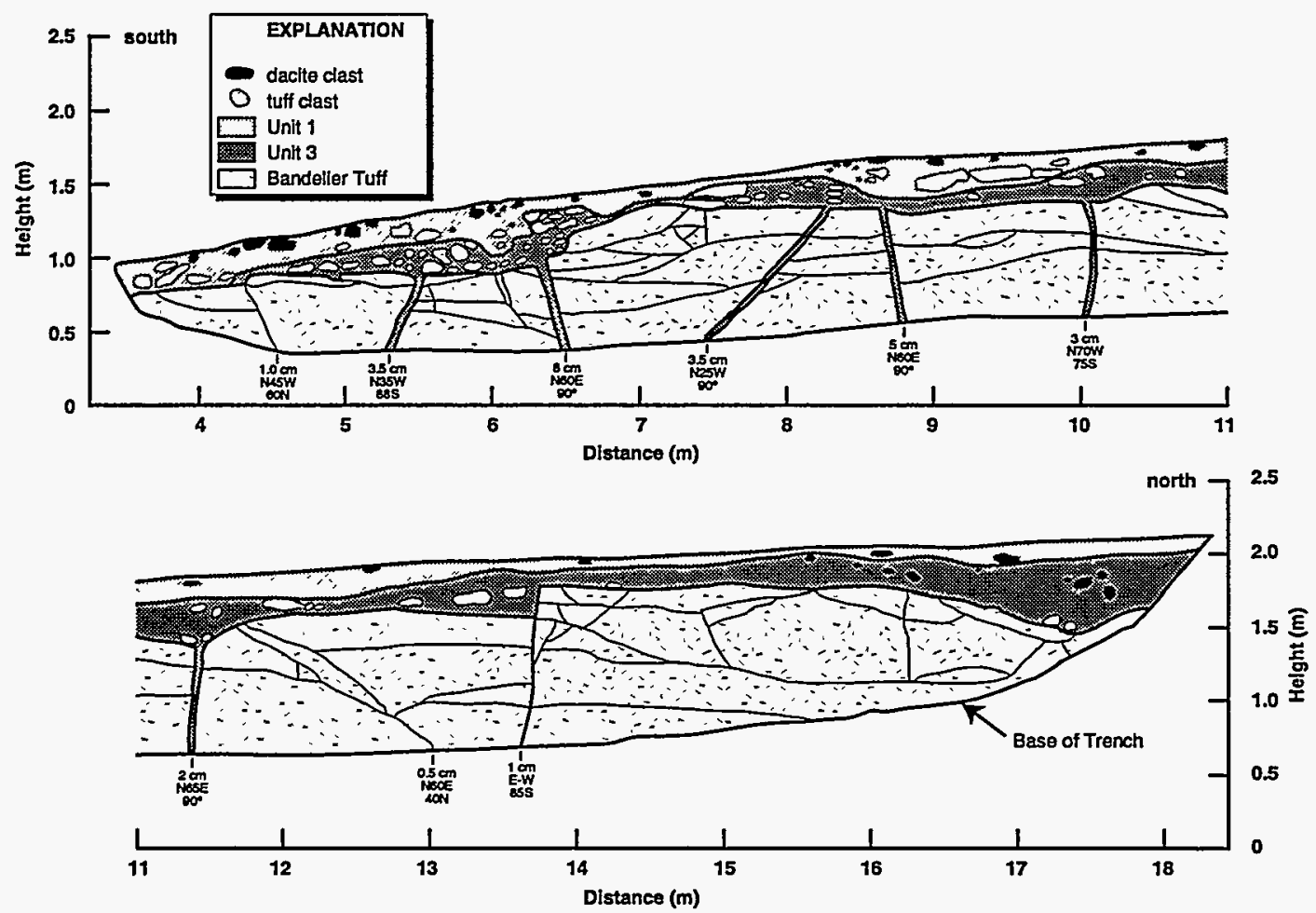

Fig. 9. Log of exploratory trench E2B excavated on south side of Pajarito Mesa, showing context of stream-rounded dacite cobbles as erosional lag deposits mixed into younger deposits. Units 1 and 3 in this trench are inferred to be correlative with units 1 and 3 of Kolbe et al. (1994). 
found on the eastern Plateau, including Mesita del Buey at TA-54 (S. Reneau, unpublished mapping, 1994). These deposits were probably much more extensive at one time, and have been largely removed by erosion. For example, rounded dacite pebbles and coarse sand were found in fractures in a trench at TA-63, north of Pajarito Canyon (trench 1 of Kolbe et al., 1995; Fig. 1), indicating the former presence of a stream at that location, although no other evidence of alluvial deposits was found on that mesa.

\section{Pre-El Cajete Soils}

The lowermost soil units at Pajarito Mesa (units $3 a$ to $3 e$ of Fig. 4), occurring beneath the El Cajete pumice, show considerable variability in thickness and degree of soil development. The base of these units typically consists of a rubble zone of Bandelier Tuff clasts within a clay-rich matrix, although unit 3 locally overlies the mesa-top alluvium. Average thickness of pre-El Cajete soils exposed in the trenches ranges from $0.3 \mathrm{~m}$ in trenches $\mathrm{W} 2$ and $\mathrm{W} 3$ to $1.0 \mathrm{~m}$ in the east half of

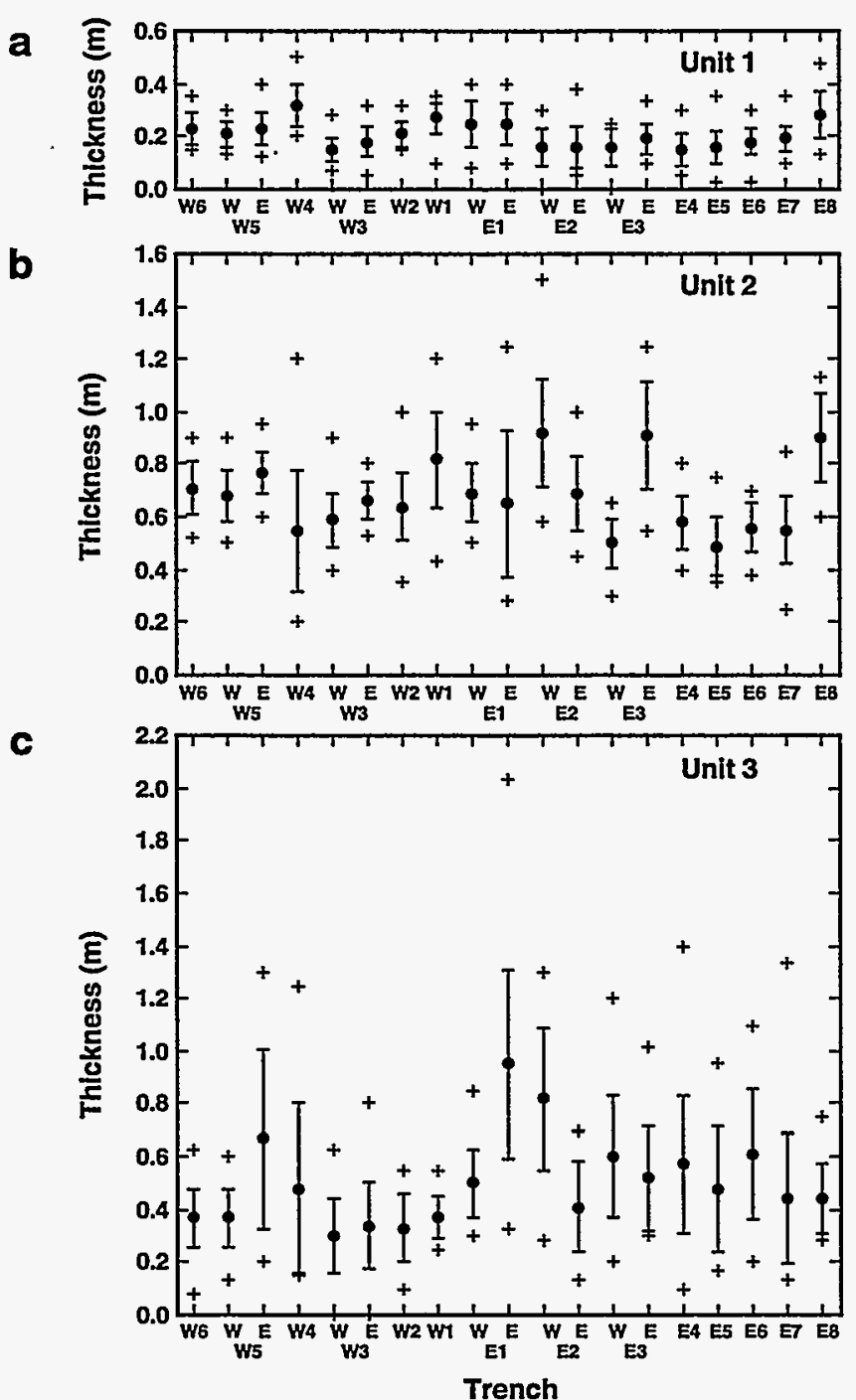

Fig. 10. Variations in thickness of a) unit 1, b) unit 2 , and c) unit 3 , in Pajarito Mesa trenches. Long trenches are divided in half. Measurements made from trench logs of Kolbe et al. (1994). Solid circles indicate mean values, bars indicate one standard deviation, and crosses indicate minimum and maximum values.
$\mathrm{E1}$, and the maximum thickness exceeds 2.0 $m$ in part of trench E1 (Fig. 10). The soils are composed of varying mixtures of weathered Bandelier Tuff, post-Bandelier alluvium and associated pumices, and eolian fine sand, silt, and clay. A significant component of windblown sediment is suggested by the textural similarity of much of unit 3 to overlying units 1 and 2, where the fine-grained fraction of deposits above the El Cajete pumice clearly have an eolian source. The local abundance of coarse sand-size quartz crystals also demonstrates that these soils include significant amounts of weathered Bandelier Tuff, and secondary silt and clay produced by in situ weathering of the tuff may also contribute to the fine-grained component of these soils. The relative contributions of eolian additions and in situ weathering to the fine fractions of the pre-El Cajete soils have not yet been determined.

The pre-El Cajete soils typically include a well-developed soil B horizon (unit $3 b$ of Fig. 4). This horizon is a reddish-brown clay or clay loam with coarse subangular blocky to prismatic soil structure (Kolbe et al., 1994). The degree of soil development in unit $3 b$, as shown by its color, clay content, and structure, is generally much greater than that present in the $\mathrm{B}$ horizon overlying the $\mathrm{EI}$ Cajete pumice (unit 2a of Fig. 4), and suggests an extended period of stability of the mesa-top soils prior to deposition of the pumice. In places, including the area of 
thickest pre-El Cajete soils in trench E1, an additional buried B horizon is locally present (unit $3 e$ of Fig. 4).

The soil unit immediately beneath the El Cajete pumice (unit 3a of Fig. 4) is extremely well indurated and has an upper boundary that is typically very distinct in the trench exposures. Unit $3 a$ locally has a distinctly hummocky upper surface, with these hummocks typically spaced about 0.4$0.5 \mathrm{~m}$ apart and with local relief of about 0.1-0.2 m. This unit is interpreted to constitute the soil $A$ horizon that was buried by the El Cajete pumice. The induration may represent partial cementation with silica derived from weathering of the pumice, although this hypothesis has not yet been confirmed with laboratory analyses. A possibly correlative unit, which has a similar degree of induration, was observed in trenches 1 and 4 at TA-63 (unit 4 of Kolbe et al., 1995). However, no overlying pumice was present at TA-63 and this correlation has not been confirmed.

The cause of the significant variations in thickness of the pre-El Cajete soils (Fig. 10c) is not clear. Although surface erosion is generally expected to be greater on steeper slopes, where other factors are equal, the variations in thickness of the pre-El Cajete soils on Pajarito Mesa do not seem to be related to the variations in slope gradient on the mesa top (Fig. 3). For example, unit 3 on the steeper area, from the middle of trench W3 to the west end of trench E3, is typically similar in thickness to unit 3 in the gentler areas east and west (Fig. 10c). The area of thickest soils, in trench E1, may be at a site where a shallow mesa-top drainage, associated with the shallow mesa-top valley to the south, was completely filled with sediment. An analogous buried drainage was exposed in trench 1 at TA-63 to the north (Kolbe et al., 1995). Altematively, the thicker unit 3 soils are in part associated with known or suspected areas of pre-El Cajete faulting, including the eastern parts of trenches W5 and E1, suggesting a local structural control. The evidence for faulting is discussed in a later section.

\section{El Cajete Pumice}

The El Cajete pumice, produced by the most recent volcanic eruptions from the Jemez Mountains, occurs along most of the length of the Pajarito Mesa trenches and constitutes an important stratigraphic marker. Deposits of undisturbed El Cajete pumice (unit 2c of Fig. 4) are up to $0.85 \mathrm{~m}$ thick in trench E8 (Fig. 11), but the tops of the deposits are probably eroded and the original thickness is unknown. The absence of outcrop-scale sorting or obvious stratigraphic layers in these deposits suggests that they represent primary volcanic fallout. Translocation of clay into the pumice beds has resulted in post-depositional development of horizontal to sub-horizontal banding ("Bt lamellae", Fig. 11), a feature that is commonly observed in deposits of the El Cajete pumice on the Pajarito Plateau (for example, see Frijoles and Seaby series descriptions of Nyhan et al., 1978, p. 24 and 29).

The pumice in trench E8 is the thickest deposit of El Cajete pumice yet found in the central part of LANL, although deposits up to $1.2 \mathrm{~m}$ thick were exposed $6 \mathrm{~km}$ west in a trench along West Jemez Road south of Cañon de Valle (Wong et al., 1995), and $2.2 \mathrm{~m}$ of primary fallout pumice occurs $6 \mathrm{~km}$ south on Frijoles Mesa, in TA-49 (Longmire et al., 1995). The axis of the El Cajete dispersal plume was towards the southeast, south of Pajarito Mesa (Self et al., 1988, 1991), and deposits of pumice should thus become thicker to the south.

The El Cajete pumice has been extensively disturbed at Pajarito Mesa. In most trenches only small scattered patches of undisturbed pumice remain (e.g., 23-25 $\mathrm{m}$ in trench W5, Fig. 5), although clasts of pumice are generally abundant in the overlying soils. The disturbed pumice was designated as unit $2 \mathrm{~b}$ (Fig. 4). The percentage of the length of each trench that contains undisturbed pumice is typically $1 \%$ to $8 \%$, although several trenches contain no undisturbed pumice and one trench, E8, has pumice along almost $90 \%$ of its length (Fig. 12). The disturbance and incomplete preservation probably reflects a combination of bioturbation of the deposits by burrowing animals, 


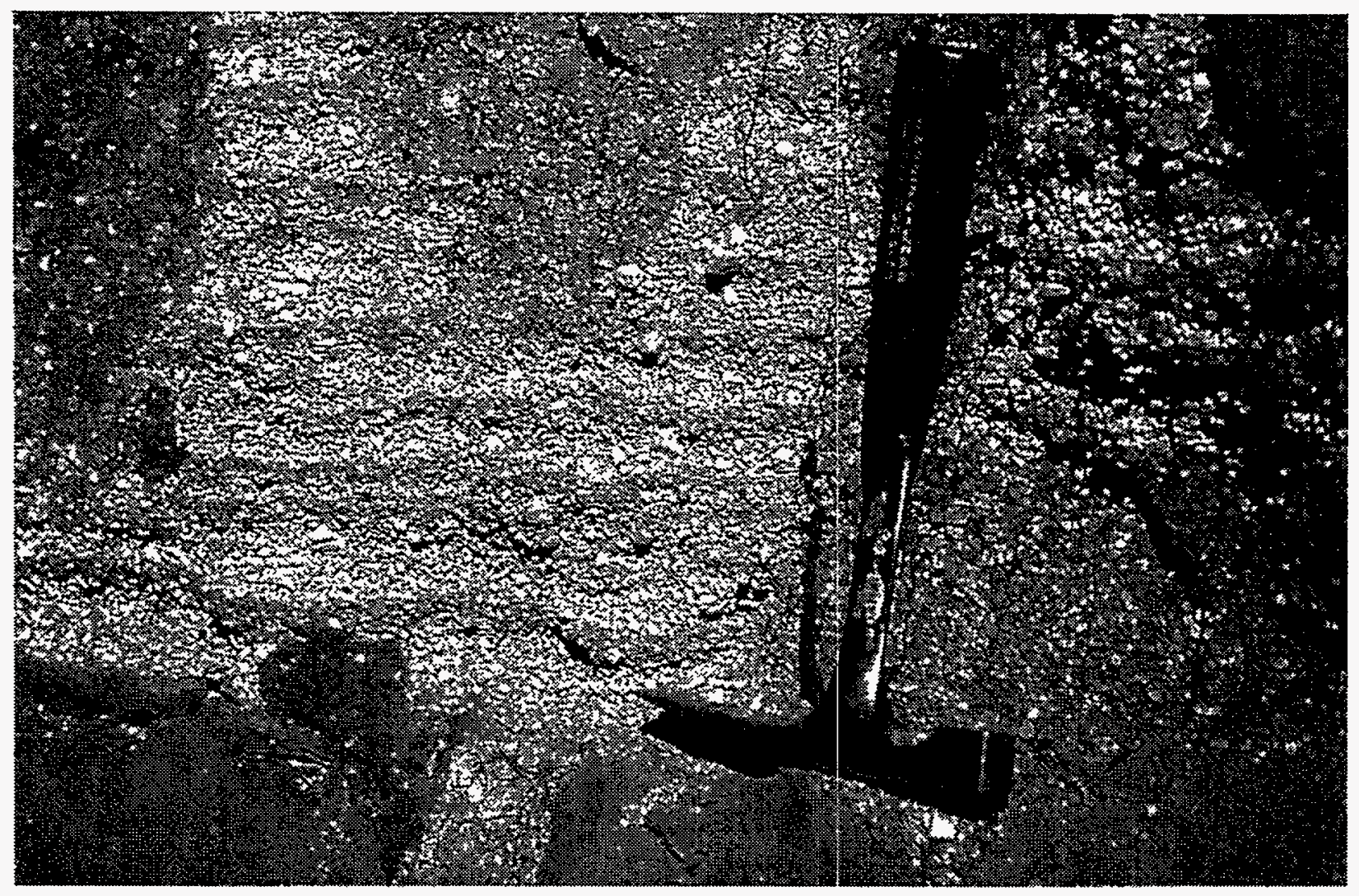

Fig. 11. Photograph of El Cajete pumice in trench E8. Sub-horizontal bands ("Bt lamellae") reflect post-depositional translocation of clay into the pumice beds. Hammer rests on top of buried unit 3 a soil horizon.

root growth and decay since deposition, and erosion by surface runoff. The reason for the anomalously great extent of El Cajete pumice in trench E8 is not certain, but its preservation may be related to reduced surface erosion on a relatively gently sloping part of Pajarito Mesa.

\section{Age of Pumice}

Conflicting ages have been obtained for the El Cajete pumice. Fission-track ages on zircon crystals from the pumice and related volcanic units in the Jemez Mountains range from 130 to $180 \mathrm{ka}$ (Marvin and Dobson, 1979; Miyachi et al., 1985), with a weighted average of $146 \pm 27$ ka. ${ }^{40} \mathrm{Ar} / 39 \mathrm{Ar}$ analyses on biotite crystals from the pumice and related units have yielded ages of 205 to $1300 \mathrm{ka}$ (Self et al., 1991), but these probably reflect xenocrystic contamination and all of these ages are apparently too old. Recent electron spin resonance (ESR) analyses suggest significantly younger ages of 45 to $73 \mathrm{ka}$ (Toyoda et al., 1995). These younger ages are generally

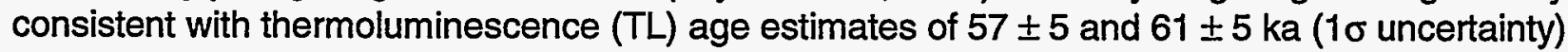
for a colluvial deposit buried beneath the pumice along West Jemez Road, and $48 \pm 5$ to $52 \pm 5 \mathrm{ka}$ from the unit $3 a$ soil immediately beneath the pumice in trench E8 (Table 3; S. Forman, written communication, 1995). Additional age constraints are provided by radiocarbon analyses of charcoal that was entrained within the pumice beds in the Jemez Mountains. Four analyses of material from the same bed by the Quaternary Isotope Laboratory, University of Washington, yielded ages ranging from $50.1 \pm 1.3$ to $>58 \mathrm{ka}$ (Table 1). Because these ages are very close to the limit of conventional radiocarbon dating, and contamination with very small amounts of modern carbon would yield erroneous "finite" ages, these analyses probably indicate an age of $>58{ }^{14} \mathrm{C} \mathrm{ka}$, although there is the possibility of a finite age (M. Stuiver, personnel communication, 1993). At 


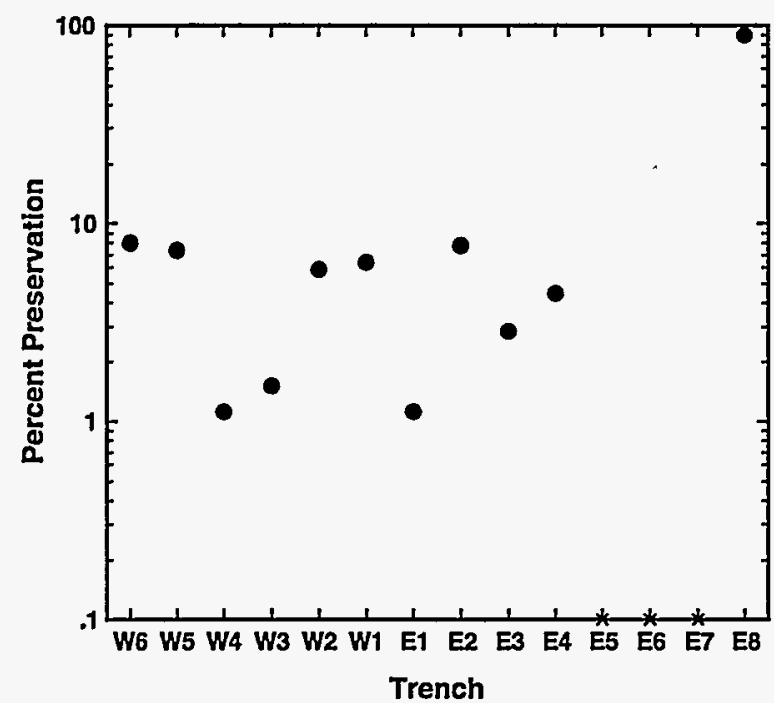

Fig. 12. Variation in preservation of primary fallout El Cajete pumice deposit (unit 2c of Fig. 4) along trenches. Vertical scale indicates percent of each trench length that contains any primary deposit; note logarithmic scale. No primary pumice was present in trenches E5, E6, or E7. Measurements made from trench logs of Kolbe et al. (1994).

young carbon prior to sampling seems to have occurred. Possible sources of field contamination include younger roots that penetrated old charcoal fragments; the burning of roots that penetrated old deposits during surface fires, producing charcoal that is much younger than the deposit; and the transport of young charcoal into old deposits within animal burrows.

\section{Post-EI Cajete Soils}

Soil units occurring above the El Cajete pumice (units $2 b, 2 a, 1 b$, and $1 a$ of Fig. 4) vary significantly in texture, morphology, and age along the trenches. As logged by Kolbe et al. (1994),

TABLE 3. Thermoluminescence Data and Age Estimates Constraining the Age of the El Cajete Pumice *

\begin{tabular}{|c|c|c|c|c|c|c|c|}
\hline $\begin{array}{l}\text { Laboratory } \\
\text { Sample } \\
\text { Number }\end{array}$ & $\begin{array}{c}\text { Equivalent } \\
\text { Dose } \\
\text { Method } 1 \\
\end{array}$ & $\begin{array}{c}\text { Light } \\
\text { Exposure } \\
{\text { (Hours })^{2}} \\
\end{array}$ & $\begin{array}{c}\text { Temperature } \\
\text { Range } \\
\left({ }^{\circ} \mathrm{C}\right)^{3} \\
\end{array}$ & $\begin{array}{c}\text { Equivalent } \\
\text { Dose } \\
\text { (grays) }\end{array}$ & $\begin{array}{c}\text { Estimated } \\
\text { Water Content } \\
\text { (wt \%) }\end{array}$ & $\begin{array}{l}\text { Dose Rate } \\
\text { (grays/ka) } 4\end{array}$ & $\begin{array}{c}\text { TL Age } \\
\text { Estimate } \\
(\mathrm{ka})^{5}\end{array}$ \\
\hline \multicolumn{8}{|c|}{ West Jemez Road, Water Tanks Trench 1} \\
\hline OTL-464 & $\begin{array}{l}\text { Total Bleach } \\
\text { Partial Bleach }\end{array}$ & $\begin{array}{l}16 h \text { sun } \\
\text { ih sun }\end{array}$ & $\begin{array}{l}250-400 \\
250-400\end{array}$ & $\begin{array}{l}253.30 \pm 5.02 \\
272.40 \pm 3.39\end{array}$ & $\begin{array}{l}25 \pm 10 \\
25 \pm 10\end{array}$ & $\begin{array}{l}4.47 \pm 0.34 \\
4.47 \pm 0.34\end{array}$ & $\begin{array}{l}57 \pm 5 \\
61 \pm 5\end{array}$ \\
\hline \multicolumn{8}{|l|}{ Pajarito Mesa. Trench E8 } \\
\hline $\begin{array}{l}\text { OTL-528 } \\
\text { OTL-516 } \\
\text { OTL-515 } \\
\end{array}$ & $\begin{array}{l}\text { Total Bleach } \\
\text { Total Bleach } \\
\text { Total Bleach } \\
\end{array}$ & $\begin{array}{l}\text { 8h UV } \\
\text { 8h UV } \\
\text { 8h UV } \\
\end{array}$ & $\begin{array}{l}250-360 \\
250-360 \\
250-360 \\
\end{array}$ & $\begin{array}{l}197.24 \pm 3.89 \\
242.90 \pm 5.58 \\
217.50 \pm 4.18 \\
\end{array}$ & $\begin{array}{l}25 \pm 10 \\
25 \pm 10 \\
25 \pm 10 \\
\end{array}$ & $\begin{array}{l}4.10 \pm 0.33 \\
4.76 \pm 0.36 \\
4.18 \pm 0.33 \\
\end{array}$ & $\begin{array}{l}48 \pm 5 \\
51 \pm 5 \\
52 \pm 5\end{array}$ \\
\hline \multicolumn{8}{|c|}{$\begin{array}{l}\text { - Thermoluminescence analyses provided by Steven Forman, Ohio State University. See Forman et al. (1993) for discussion of } \\
\text { dating method. } \\
1 \text { All TL measurements were made with a Coming } 5 / 58 \text { and HA-3 filters in front of the photomultiplier tube. Samples were preheated } \\
\text { to } 124^{\circ} \mathrm{C} \text { for } 48 \text { hrs prior to analysis. } \\
2 \text { Hours of light exposure to define residual level. "Sun" is natural sunlight in Columbus, Ohio. UV is light exposure from } 275 \text { watt } \\
\text { General Electric ultraviolet "sunlamp". } \\
3 \text { Temperature range used to calculate equivalent dose. }\end{array}$} \\
\hline \multicolumn{8}{|c|}{$\begin{array}{l}4 \text { Dose rates were calculated using values of } K, T h \text {, and } U \text { analyzed at the Ohio State University and the estimated water content. } \\
\text { For samples from major stratigraphic contacts, the radionuclide contents from the overlying pumice and underlying soil were } \\
\text { averaged. } \\
5 \text { All errors are at one sigma and calculated by averaging the errors across the temperature range. }\end{array}$} \\
\hline
\end{tabular}


unit $2 \mathrm{~b}$ generally consists of El Cajete pumice that has been disturbed by bioturbation (burrowing animals, root growth, etc.); unit 2a consists of a buried soil B horizon developed within the disturbed pumice or on overlying deposits; unit $1 \mathrm{~b}$ consists of material deposited unconformably on top of unit $2 \mathrm{a}$, which locally contains cultural material near Anasazi ruins; and unit 1a consists of the uppermost silty soils, largely deposited since Anasazi occupation. Unit 1 averages 0.1 to $0.3 \mathrm{~m}$ thick in the trenches, with a maximum thickness of $0.5 \mathrm{~m}$ (Fig. 10a), and unit 2 averages 0.5 to 0.9 $\mathrm{m}$ thick, with a minimum and maximum thickness of 0.2 and $1.5 \mathrm{~m}$, respectively (Fig. 10b). Units $2 a, 1 b$, and $1 a$ are typically much finer grained than unit $2 b$, with high concentrations of fine sand and silt, and they record the deposition of substantial amounts of wind-blown sediment on Pajarito Mesa since the El Cajete eruptions.

Field observations and radiocarbon ages indicate that unit $2 a$ varies significantly along the trench exposures, and contains a complex history of sediment deposition, soil development, and erosion. Ages obtained from unit $2 a$ are 26 to $30 \mathrm{ka}$ in trenches E2 and W1, $11.6 \mathrm{ka}$ in trench E4, 8.8 to $9.5 \mathrm{ka}$ in trenches E1, E2, E5, and W3, and 1.8 to $3.1 \mathrm{ka}$ in trench W2 (Table 2). Sketches of some of the radiocarbon sample sites are shown in Fig. 13, and possible stratigraphic relations between unit $2 a$ deposits in different parts of the trenches are shown in Fig. 14. Although it is possible that some of the younger dates reflect contamination of the deposits with young carbon, the variations in apparent ages are associated with lateral variations in soil characteristics, and none of the unit $2 a$ dates can be clearly rejected. The available data suggest that incorporation of some wind-blown sediment into disturbed El Cajete pumice deposits prior to 26 to 30 ka was followed by a period of relative stability of the mesa top, during which time soil development progressed. Soil development may also have been in part concurrent with eolian deposition, resulting in a cumulative soil profile. These older unit 2 a deposits had been locally eroded prior to deposition of younger fine-textured unit 2a deposits in trenches E1 and E2 at about $9.5 \mathrm{ka}$. Significant erosion of mesa-top soils after $9.5 \mathrm{ka}$ has also probably occurred, although it is not possible to determine the total amount of erosion.

The early Holocene unit $2 a$ deposits (9-10 ka) may represent either a separate period of eolian influx or, less likely, extensive local reworking of older deposits. A time of major climatic transition began about $11 \mathrm{ka}$ in the southwestern United States, when vegetation associated with wetter Pleistocene climates was replaced by plants more typical of modern climates (Spaulding et al., 1983; Van Devender et al., 1987). These climatic changes probably affected the depositional history on Pajarito Mesa. Specifically, the transition to a drier climate and accompanying vegetation changes may have increased the susceptibility of both the Pajarito Plateau and lower elevation areas to the south and southwest to wind erosion, and thereby increased eolian input to mesas on the Plateau. The unit 1 deposits may similarly reflect either additional eolian input in the last 1000 years, or else significant erosion and redeposition of older sediments, perhaps associated with disturbance of the mesa top by Anasazi cultivation or historic grazing. More data on the age and characteristics of the post-El Cajete soils are needed to evaluate these hypotheses.

All of the unit 2a deposits have probably been affected by local disturbances since deposition, such as by burrowing animals, root growth, and tree toppling, which would contribute to heterogeneity within each unit $2 a$ depositional unit. For example, within an area of generally poorly-developed unit 2a soils in trench W1, field examination indicated the local occurrence of deposits that appeared much more indurated, presumably reflecting stronger soil development. One of these more indurated sites yielded an age of about $26 \mathrm{ka}$ (Table 2), suggesting that small patches of older deposits can locally exist within younger soils after extensive bioturbation of these horizons.

The combined thickness of units 1 and 2 on Pajarito Mesa averages 0.6 to $1.2 \mathrm{~m}$ along the trenches, with minimum and maximum thicknesses of 0.4 and $1.6 \mathrm{~m}$, respectively (Fig. 15a). Because Pajarito Mesa was probably buried by an approximately uniform thickness of pumice at about 50-60 ka, significant spatial variations in net erosion since that time would presumably be 
E3 RCS $4=540 \pm 60 \mathrm{BP}, 1410 \mathrm{cal} A D$

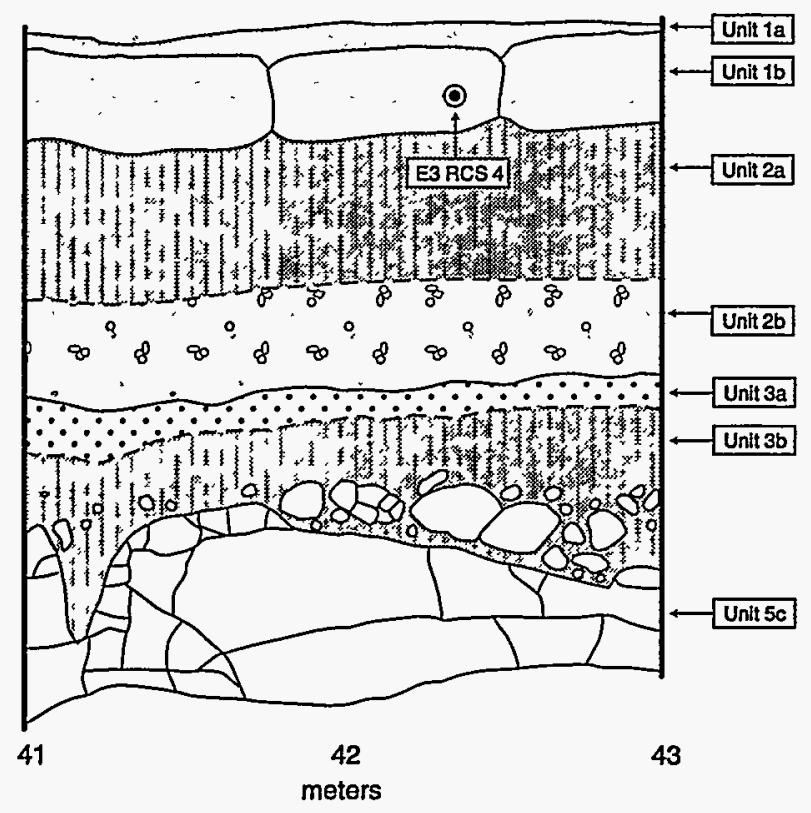

E2 RCS $9=9400 \pm 60 \mathrm{BP}, 8420 \mathrm{cal} \mathrm{BC}$

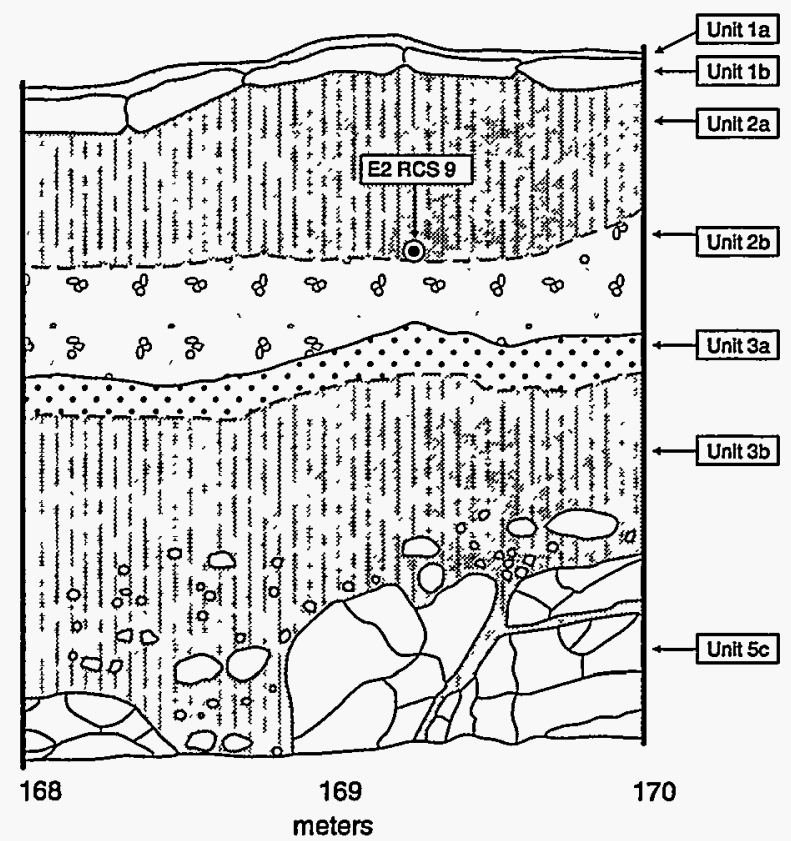

W2 RCS $2=1870 \pm 60 \mathrm{BP}, 140 \mathrm{cal} A \mathrm{D}$

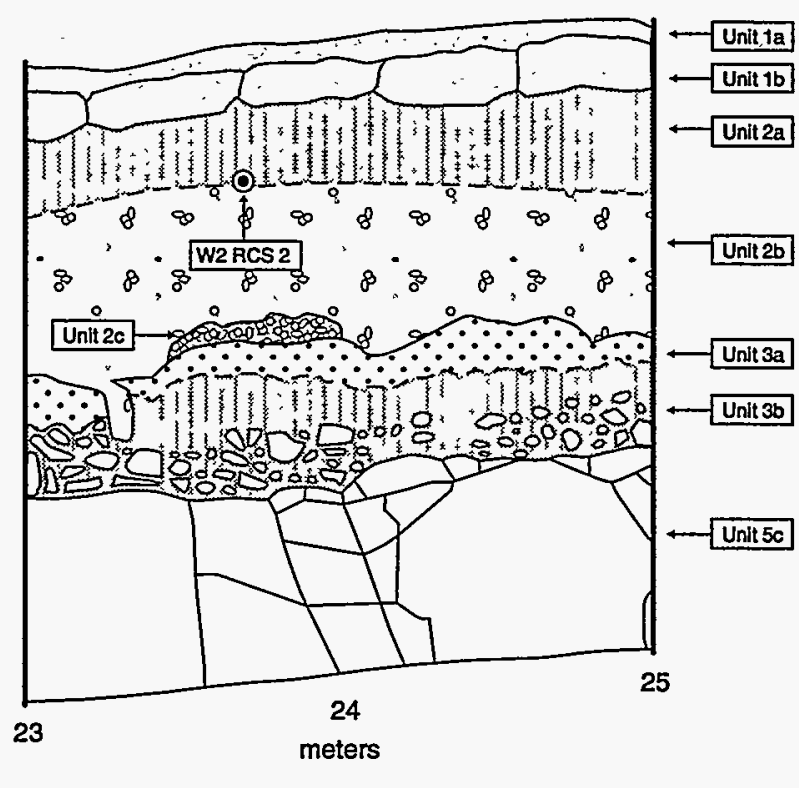

E2 RCS $4+7=30,070 \pm 210 \mathrm{BP}$

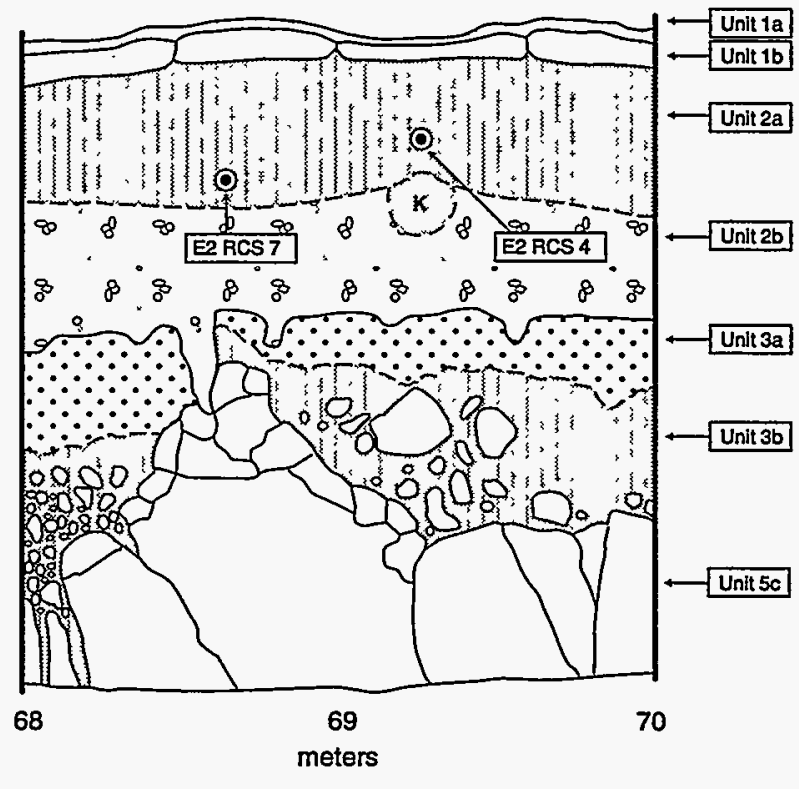

Fig. 13. Sketches of selected radiocarbon sample locations, from Kolbe et al. (1994). No vertical exaggeration. 




Fig. 14. Schematic sketch showing inferred stratigraphic relations of unit 2a packets in different parts of the Pajarito Mesa trenches.

recorded by variations in the total thickness of the pumice and younger units. Notably, no systematic variations in thickness occur related to the variations in the gradient of the mesa top, although slope gradient is an important variable in models developed to predict soil erosion rates (such as the Universal Soil Loss Equation, Wischmeier and Smith, 1978). Some of the thicker post-El Cajete soils, in trenches E1 and E2 (Fig. 15a), actually occur on a steep part of the mesa.

Proximity to the mesa edges seems to be a more important factor affecting net erosion than mesa-top gradient. The areas of thinnest soils occur along the eastern trenches where the mesa is narrowest (Fig. 1), although local areas of thicker soils are also present to the east (e.g., trench E8) (Fig. 15a). Clasts of El Cajete pumice are very rare in trenches E6 and E7, and presumably this reflects extensive local erosion prior to deposition of the finer-grained unit 2 sediments. Greater erosion towards the mesa edge, resulting in thinner soils, is also seen in a north-south transect across Pajarito Mesa that includes trenches E2, E2A, and E2B (Fig. 8). Unfortunately, because the original thickness of the pumice and younger eolian deposits on Pajarito Mesa is unknown, no calculations can be made of average long-term mesa-top erosion rates at this time.

It is significant that the last 700 to 1000 yr have been characterized by net deposition, not erosion, on the crest of Pajarito Mesa. Using the average thickness of unit 1 of about $0.2 \mathrm{~m}$ (Fig. 10 ) and the ages of 1290 A.D. or younger for the unit $1 \mathrm{~b}$ deposits (Table 2), indicates an average deposition rate of about $0.3 \mathrm{~mm} / \mathrm{yr}$ for the last $700 \mathrm{yr}$. There clearly has been great spatial and 

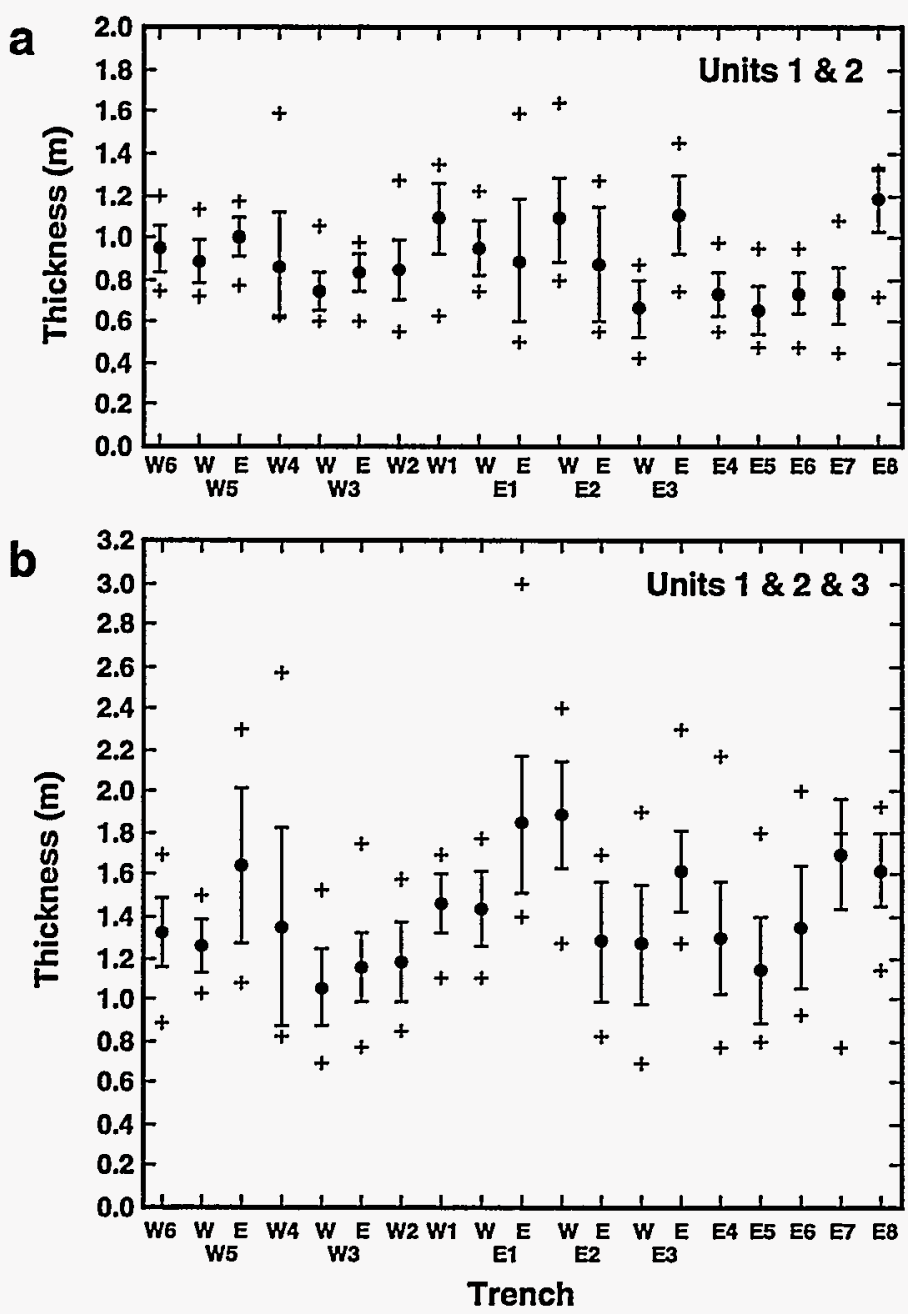

Fig. 15. Variations in total thickness of a) unit 1 plus unit 2, and b) units 1, 2, and 3, in Pajarito Mesa trenches. Long trenches are divided in half. Measurements made from trench logs of Kolbe et al. (1994). Solid circles indicate mean values, bars indicate one standard deviation, and crosses indicate minimum and maximum values. otherwise barren of clasts (Figs. 6, 16, and 17). These clasts were commonly oxidized, and were typically associated with charcoal. Oxidized soil, providing further evidence of prehistoric fires, was seen in some sites, and baked clay was found at one site (W4 RCS4 sample site). Textural and structural differences between material within the sites and adjacent soils also helped delineate many of the sites. The archaeological sites exposed in the Pajarito Mesa trenches appear to cluster into two general temporal groups: a younger group associated with Anasazi occupation of the mesa and an older less distinct group dating to the pre-Anasazi Paleo-Indian period.

As logged by Kolbe et al. (1994), the younger sites were interpreted to be typically excavated into the unit 2 soils and to be overlain by unit $1 \mathrm{~b}$, although at least one site was logged as excavated through unit 16 and into unit 2 (W4 RCS1 site, Fig. 16). These younger sites are located within 100 $m$ of small mesa-top ruins that have been assigned to the Coalition period (1100 to 1325 A.D.) and the Classic period (1325 to 1600 A.D.) of the Rio Grande Anasazi (Hoagland et al., 1994). Regional surveys have indicated that usage of mesas at this relatively high elevation peaked in the Late 
Coalition period, 1250 to 1325 A.D., although it continued into the Late Classic period (1550 to 1600 A.D.) (Stuart and Gauthier, 1981; Orcutt, 1991). The calibrated calendar ages of charcoal collected from six sites in trenches W4 and E8 range from 1010 to 1450 A.D. (Table 2), and include dates that are in part older than expected from the surface archaeological survey. Although this may suggest previously unrecognized occupation of Pajarito Mesa during the Late Developmental period (900 to 1100 A.D.), the apparent discrepancy may instead reflect either the burning of relatively old wood by the Anasazi or the analytical uncertainties inherent in radiocarbon dating.

Radiocarbon ages obtained from unit $1 b$ throughout the trenches are similar to or younger than the ages obtained from the Anasazi sites, with calibrated calendar ages from 1290 A.D. to post-1955 A.D. (Table 2). This supports the interpretation of Kolbe et al. (1994) from the trench logging that unit 1 is generally contemporaneous with or younger than the Anasazi occupation. A comparison of the calibrated radiocarbon data from the archaeological sites and from unit $1 \mathrm{~b}$ is shown in Fig. 18. The data in Fig. 18 are calculated probabilities of the calibrated sample ages,

E8 RCS $1=760 \pm 50 \mathrm{BP}, 1280 \mathrm{cal}$ AD E8 RCS $2=>45,400 \mathrm{BP}$

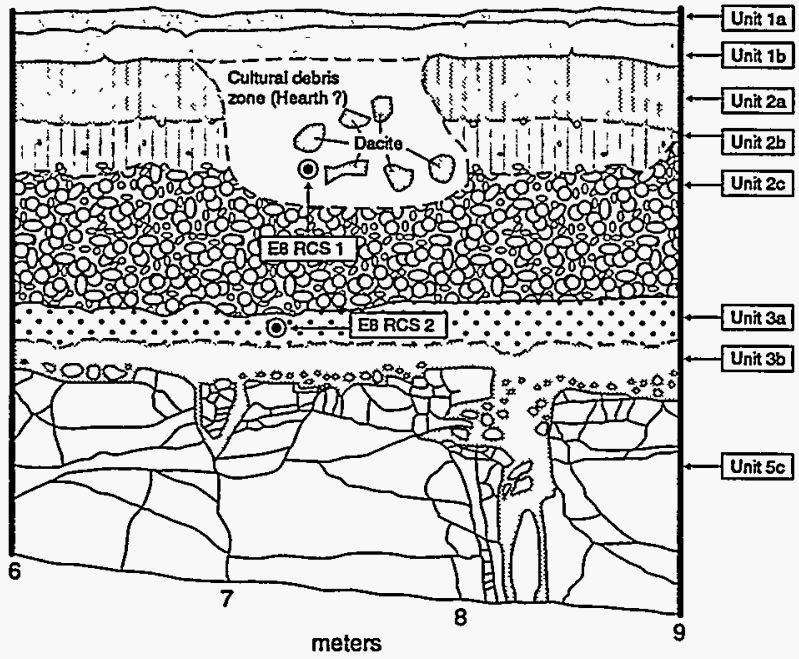

E1 RCS $2=9490 \pm 90 \mathrm{BP}$, E1 RCS $2 a=9470 \pm 60 B P$ $8530 \mathrm{cal} \mathrm{BC}$

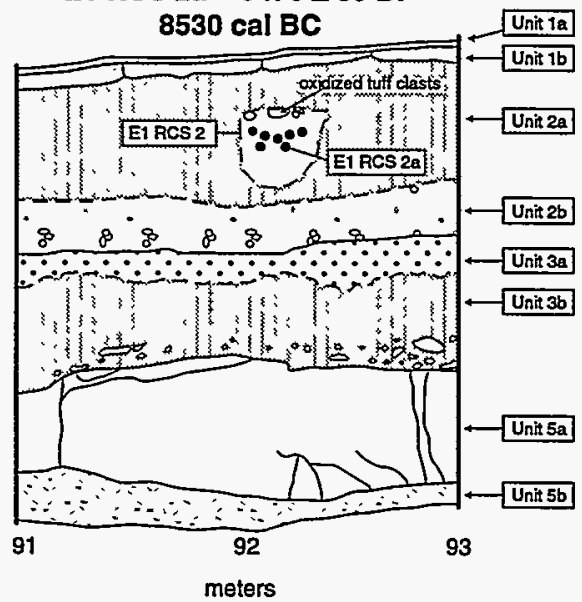

W4 RCS $1=895 \pm 55$ BP, 1165 cal AD

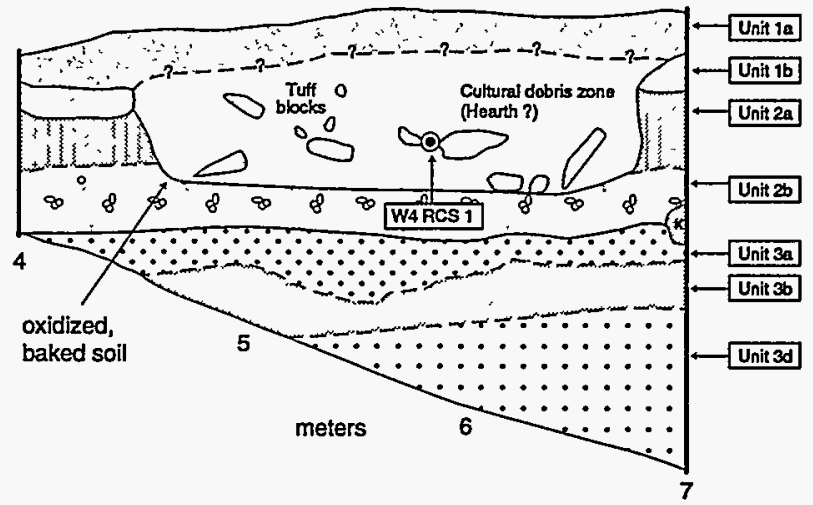

W3 RCS $4=8770 \pm 50 \mathrm{BP}$, $7740-7890$ cal BC

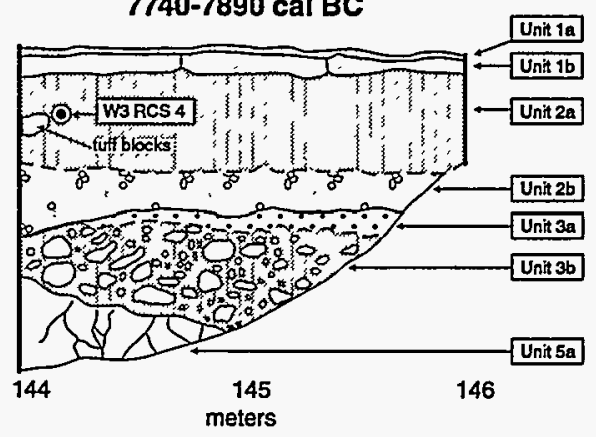

Fig. 16. Sketches of inferred archaeological sites exposed in Pajarito Mesa trenches, from Kolbe et al. (1994). No vertical exaggeration. 


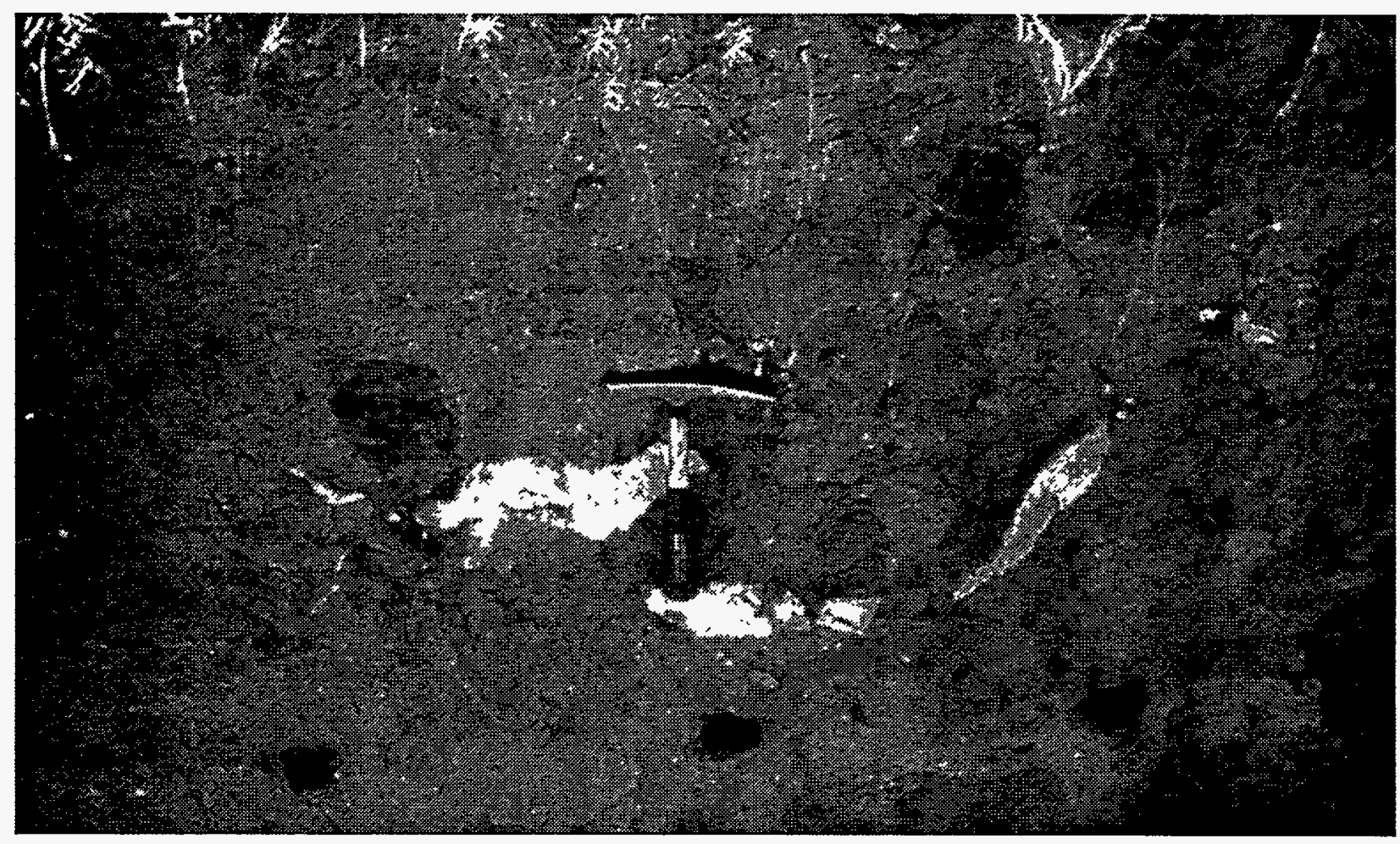

Fig. 17. Photograph of tuff blocks in buried archaeological site at trench W4 RCS1 sample site (1165 cal A.D.).

which show the relative probability that the true sample age is represented by specific calendar years. These data include the laboratory uncertainty of the true age of each sample and an error multiplier of 2.0, as discussed earlier. Other uncertainties, including the age of the wood when it was burned and possible contamination with younger carbon, are not included in these probabilities. Figure 18 shows that the typical unit $1 \mathrm{~b}$ ages of 1300 to 1400 A.D. post date the typical ages of 1000 to 1300 A.D. from the archaeological sites. The 1300 to 1400 A.D. unit $1 \mathrm{~b}$ ages suggest that much of this unit was deposited during the Classic period of the Rio Grande Anasazi, although it is not known whether deposition was directly related to Anasazi disturbances.

Three of the inferred sites, exposed in trenches E1, E5, and W3, at sites generally farther from ruins, yielded surprisingly old ages of about 8.8 to $9.5 \mathrm{ka} \mathrm{(7740} \mathrm{to} 8820$ B.C.; Table 2). These ages correspond to the Paleo-Indian period in New Mexico (10,000 B.C. to 5500-4000 B.C.; ages from Cordell, 1979, 1984; Stuart and Gauthier, 1981; Hoagland et al., 1994), and would represent the oldest buried sites found on the Pajarito Plateau, although older Folsom points (ca. 10 to 11 ka) have been previously found on the Plateau (Steen, 1977, 1982). The trench E1 and E5 sites display the strongest evidence for pre-Anasazi occupation, with scattered heavily oxidized tuff clasts occurring within unit $2 \mathrm{a}$, about $1 \mathrm{~m}$ higher than other tuff clasts in the soil (Fig. 16). Because of its potential archaeological significance, charcoal was re-collected from the E1 site after the first radiocarbon analysis had been completed, and a second analysis confirmed the accuracy of the $9.5 \mathrm{ka}$ age (Table 2). The stratigraphy exposed in the trench walls at both the E1 and E5 sites suggests that the dated material represents shallow fire pits that were constructed during a period of early Holocene mesa-top aggradation, with the sites buried and preserved by continued deposition of fine-grained sediment. It is also possible that the fire pits were excavated into older deposits, 
and that subsequent soil development has masked differences in deposit age. However, a similar radiocarbon age of $9.4 \mathrm{ka}$ from a very similar deposit in trench E2 (E2 RCS9, Table 2) provides supporting evidence for an extensive period of aggradation at this time.

The $8.8 \mathrm{ka}$ trench $\mathrm{W} 3$ site is more problematic, with non-oxidized tuff clasts occurring about $0.5 \mathrm{~m}$ above other clasts in the unit 3 rubble zone (Fig. 16). Biological disruption of this soil profile by a toppling tree, bringing tuff blocks up to the surface, cannot be ruled out. No artifacts were seen at the sites in trenches $E 1, E 5$, and W3, and a better understanding of their significance will require archaeological excavation.

One inferred archaeological site in trench W5, identified by the occurrence of oxidized tuff clasts in unit $2 \mathrm{a}$, in association with abundant charcoal, yielded an intermediate radiocarbon date of $2.75 \mathrm{ka}$ (900 B.C., Table 2). This date suggests an association with the Archaic period (6000-4000 B.C to 600A.D.; ages from Cordell, 1979, 1984; Hoagland et al., 1994). However, although the tuff clasts indicate the presence of an archaeological site, the dated charcoal was unusually abundant and could conceivably represent a root burned in the soil either before or after occupation. The context of this date is therefore uncertain.

\section{Relation to Los Alamos County Soil Survey}

The extensive transects of soils exposed in trenches at Pajarito Mesa (Kolbe et al., 1994), and also in the TA-63 area to the north (Fig. 1, Kolbe et al., 1995), provide an opportunity to check the general mapping units employed in the soil survey of Los Alamos County (Nyhan et al., 1978), and to place these mapping units in the context of the depositional history of the mesas.

The predominant soil series mapped along
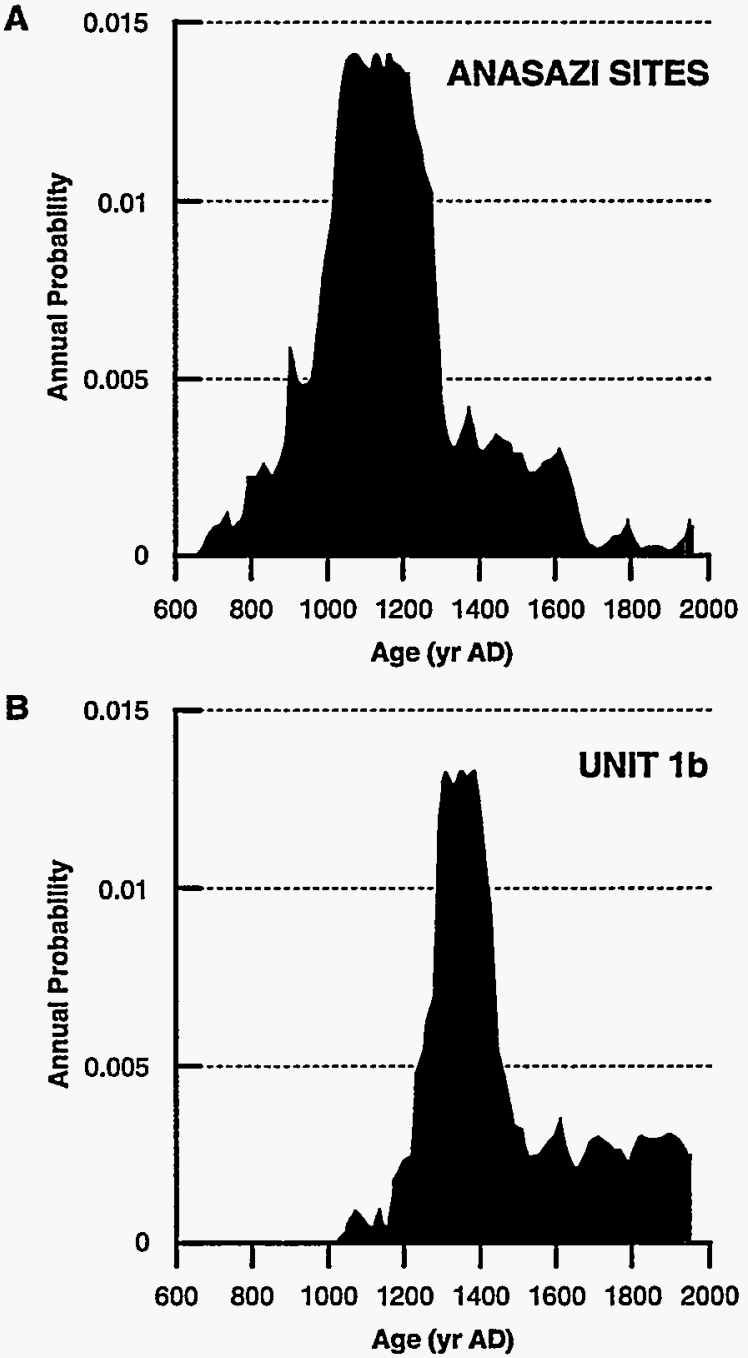

Fig. 18. Probability plots showing radiocarbon analyses from A) Anasazi sites in trenches E8 and W4, and B) unit ib deposits in trenches W2, W3, $E 3$, and E5. The probability data were obtained using the computer program CALIB 3.03 of Stuiver and Reimer (1993), and indicate the relative probabilities that the calibrated ages represent the actual sample ages. The plots represent the sum of the annual probabilities for each sample. The probabilities include both analytical uncertainties and uncertainties in calibrated ages due to variations in the ${ }^{14} \mathrm{C} /{ }^{12} \mathrm{C}$ ratio in the atmosphere over time.

the crest of Pajarito Mesa, and also at the TA-63 trenches 1 and 4, is the Nyjack loam. As described: "Typically, the surface layer is a brown loam, very fine sandy loam, or sandy loam about $5 \mathrm{~cm}$ thick, and the subsoil is a brown clay loam about $50 \mathrm{~cm}$ thick. The substratum is a gravelly sandy loam about $40 \mathrm{~cm}$ thick, which may contain as much as $30 \%$ pumice. Depth to tuff bedrock and the effective rooting depth range from 50 to $102 \mathrm{~cm}$ " (Nyhan et al., 1978, p. 25). The surface layer, subsoil, and substratum as described by Nyhan et al. (1978) generally seem to correspond well to units $1,2 a$, and $2 b$ of Kolbe et al. (1994) at Pajarito Mesa, with the pumice referred to by Nyhan et al. (1978) being the El Cajete pumice. The main difference between the descriptions of Nyhan et al. (1978) and the trench data are in the depth to tuff bedrock, which at Pajarito Mesa ranges from 
0.7 to $2.6 \mathrm{~m}$ and averages 1.0 to $1.9 \mathrm{~m}$ in the trenches (Fig. 15b), and in the occurrence of buried soils (unit 3 of Kolbe et al., 1994) which were not described by Nyhan et al. (1978). Notably, the soils at TA-63 trenches 1 and 4 are also mapped as part of the Nyjack series by Nyhan et al. (1978), yet the TA-63 soils (Kolbe et al., 1995) are strikingly different from the typical soils at Pajarito Mesa, with the complete absence of El Cajete pumice. The TA-63 soils thus either seem most similar to the Pajarito Mesa trench E6 and E7 soils, where El Cajete pumice clasts were rare, or with the Pajarito Mesa unit 3, which may have been exposed by erosion of the pumice and younger deposits.

Also mapped by Nyhan et al. (1978) at the Pajarito Mesa trench sites are Frijoles very fine sandy loam on the mesa top and Hackroy sandy loam on the southern mesa margins. The Frijoles series, as described by Nyhan et al. (1978), is similar to the Nyjack series in that it contains abundant pumice, but differs in "having formed in thick pumice beds" (Nyhan et al., 1978, p. 24), presumably in extensive areas of undisturbed El Cajete pumice such as were exposed in trench E8. In contrast, the description of the Hackroy series does not mention pumice and instead indicates a higher clay content. "The surface layer of the Hackroy soils is a brown sandy loam, or loam, about $10 \mathrm{~cm}$ thick. The subsoil is a reddish brown clay, gravelly clay, or clay loam, about $20 \mathrm{~cm}$ thick. The depth to tuff bedrock and the effective rooting depth are 20 to $50 \mathrm{~cm}$ " (Nyhan et al., 1978, p. 25). This description seems to agree well with the lower soils exposed in trench E2B on the south side of Pajarito Mesa (Fig. 9), and with the typical TA-63 soils of Kolbe et al. (1995).

As interpreted from the Pajarito Mesa trench exposures, the Frijoles series and Nyjack series constitute soils developed in eolian-deposited sediments above the El Cajete pumice during the last $50-60 \mathrm{ka}$. The original pumice deposits have been largely disturbed by bioturbation or stripped by erosion in the Nyjack soils, whereas more extensive areas of undisturbed pumice underlie typical Frijoles soils, although the soil mapping boundaries may not correspond to the actual boundaries of the pumice deposits. Frijoles soils are not mapped north of Pajarito Mesa (Nyhan et al., 1978), and this reflects the greater original thickness of El Cajete pumice on the southern Pajarito Plateau, closer to the axis of the dispersal plume (Self et al., 1988, 1991). Pumice, presumably the El Cajete, is also noted in the Seaby series (Nyhan et al., 1978), and may occur in other series as well. The Hackroy series is interpreted to typically constitute older clay-rich soils that were once buried by the pumice, with the pumice having been subsequently eroded. The thick deposits of post-El Cajete eolian-derived sediments have also apparently been eroded from areas mapped as the Hackroy series, in turn suggesting that these areas have a higher susceptibility to surface erosion.

These observations illustrate the general relationship of the mapped soil series to the geomorphic history of deposition and erosion on Pajarito Plateau mesas, and the utility of the soil survey in examining gross spatial variations in the geomorphic history of the mesas. However, it is clear that substantial variation in soil characteristics and soil thickness can occur within the mapping units of Nyhan et al. (1978), and that site-specific data are required to confirm the accuracy of the mapping units at any location.

\section{STRUCTURE}

Data on faulting at Pajarito Mesa have been obtained by several methods, including geologic mapping, logging of fractures and surficial units in the exploratory trenches, detailed surveying of a stratigraphic contact within the Bandelier Tuff, and examining bedrock and topographic profiles. Fault zones on this part of the Pajarito Plateau have been difficult to map and characterize because they seem to display relatively little post-Bandelier displacement $(<10 \mathrm{~m})$ and because the fault offset may be dispersed along many fractures in zones hundreds of meters wide (Vaniman and Wohletz, 1990). In addition, the boundaries of most mapping units within the Bandelier Tuff are not 
sharply defined, such as between welded and nonwelded tuff, making recognition of small offsets problematic. Fault offsets can be most precisely measured where distinct stratigraphic boundaries, such as post-Bandelier alluvial layers or surge beds within the Bandelier Tuff, are exposed. In these cases offsets of $10 \mathrm{~cm}$ or less can be recognized and measured. However, exposures of the surge beds between Tshirege Member unit 3 and unit 4 at Pajarito Mesa are very discontinuous, with this contact being typically covered by colluvium, obscuring the stratigraphic evidence for or against faulting. In addition, the mesa-top alluvium was only exposed along a small fraction of the total trench length ( $45 \mathrm{~m}$, or $3.4 \%$ ), and faults that pre-clated the soil units may have been unrecognizable in most trench exposures. Because of these difficulties, data from geologic mapping and from the trench exposures were supplemented with $\mathrm{km}$-long surveys of the surge beds along the south margins of both Pajarito Mesa and Twomile Mesa to the north, in order to evaluate possible dispersed deformation of the Bandelier Tuff. In addition, longitudinal profiles of bedrock in the trenches and of the mesa top were examined to further constrain possible deformation in areas where the surge beds are not present. Together, these methods allow a more complete evaluation of the location and amount of faulting at Pajarito Mesa, although many details remain unresolved.

\section{Faulting of Surficial Units}

The buried soil beneath the El Cajete pumice is generally continuous along the $1340 \mathrm{~m}$ of trench exposure, constituting an outstanding stratigraphic marker to constrain possible faulting over the last $50-60 \mathrm{ka}$. Although this soil has been locally disturbed, probably by burrowing animals and root growth, no tectonic deformation of the soil was recognized, documenting the lack of faulting during the past 50-60 ka on this part of Pajarito Mesa (Kolbe et al., 1994). Notably, this indicates that the most recent surface ruptures that were previously documented along the Guaje Mountain and Rendija Canyon faults to the north (Gardner et al., 1990; Kelson et al., 1993; Wong et al., 1993, 1995) either terminated somewhere north of Pajarito Mesa or were accommodated on other unrecognized fault traces to the east or west. This is consistent with the conclusion of Kolbe et al. (1995) that no Holocene faulting had occurred along the southern projection of the Guaje Mountain fault zone at the TA-63 trench sites north of Pajarito Mesa.

Faulting of post-Bandelier deposits on Pajarito Mesa has only been identified in trench W5, where seven discrete faults with at least $1.2 \mathrm{~m}$ of cumulative down-to-the-west offset were recognized over a distance of $20 \mathrm{~m}$ (Kolbe et al., 1994). These faults offset the pumice-rich alluvium (Figs. 5 and 19), which is presumably greater than $1 \mathrm{Ma}$ in age. The faults typically were truncated upward at the base of unit 3 , although one fault with $5 \mathrm{~cm}$ of offset could be traced as a clay-filled fracture into unit $3 b$ ( $35.5 \mathrm{~m}$, Fig. 5). The possible continuation of a fault into unit $3 \mathrm{~b}$ indicates that multiple episodes of faulting may be recorded in the trench W5 fault zone, although the evidence for postunit $3 b$ faulting at that location is inconclusive. Additional evidence for possible recurrent movement in this fault zone is provided by the observation that offset on fault W5-5 may have occurred during deposition of unit $4 \mathrm{~b}$, whereas movement on other faults post-dated deposition of unit $4 \mathrm{a}$ (Fig. 5, Kolbe et al., 1994).

The faults are steeply dipping and show evidence of both normal and reverse movement. They typically branch upward within the alluvium into multiple splays. No slickensides were obsenved. Only four of the fractures displaying offset could be traced to the opposite trench wall, suggesting that the others transferred movement to intersecting fractures with different orientations, although the north trench wall was not logged and this inference was not tested. Strikes of the four continuous faults range from N70W to N-S to N48E, also suggesting a locally complex pattern of faulting.

Eastward tectonic tilting of the trench W5 alluvium is indicated by its relatively high dips of $5^{\circ}$ to $20^{\circ}$, which is possibly associated with rotation of blocks west of a larger fault that was not recognized in the trenches. As discussed above, the mesa-top alluvium only occurs along a small 
part of the total trench length, and pre-El Cajete faulting of similar magnitude to that documented in trench W5, if it was present, may not be recognizable elsewhere in the trenches because of the absence of suitable pre-El Cajete, postBandelier stratigraphic markers. The available trench data are thus insufficient to eliminate the possibility of faulting between 1.22 $\mathrm{Ma}$ and 50-60 ka elsewhere.

\section{Faulting of Bandelier Tuff}

Mapping and surveying of stratigraphic contacts within the Bandelier Tuff provides evidence for Quaternary faulting at Pajarito Mesa that supplements the evidence reported by Kolbe et al. (1994) for offsets of the mesa-top alluvium. Vaniman and Chipera (this report) reported the possibility of about $4 \mathrm{~m}$ of down-to-the-east faulting of the top of Tshirege Member unit 2 in a $335 \mathrm{~m}$ wide zone in Threemile Canyon, south of trenches W5 to W2. In addition, Vaniman and Chipera (this report) reported three small faults in the surge beds separating Tshirege Member units 3 and 4 on the south side of Pajarito Mesa, with about 23 to $30 \mathrm{~cm}$ of offset both down to the southeast and down to the southwest.

To supplement these data on post-Bandelier faulting, a detailed survey of the surge beds at the contact between Tshirege Member units 3 and 4

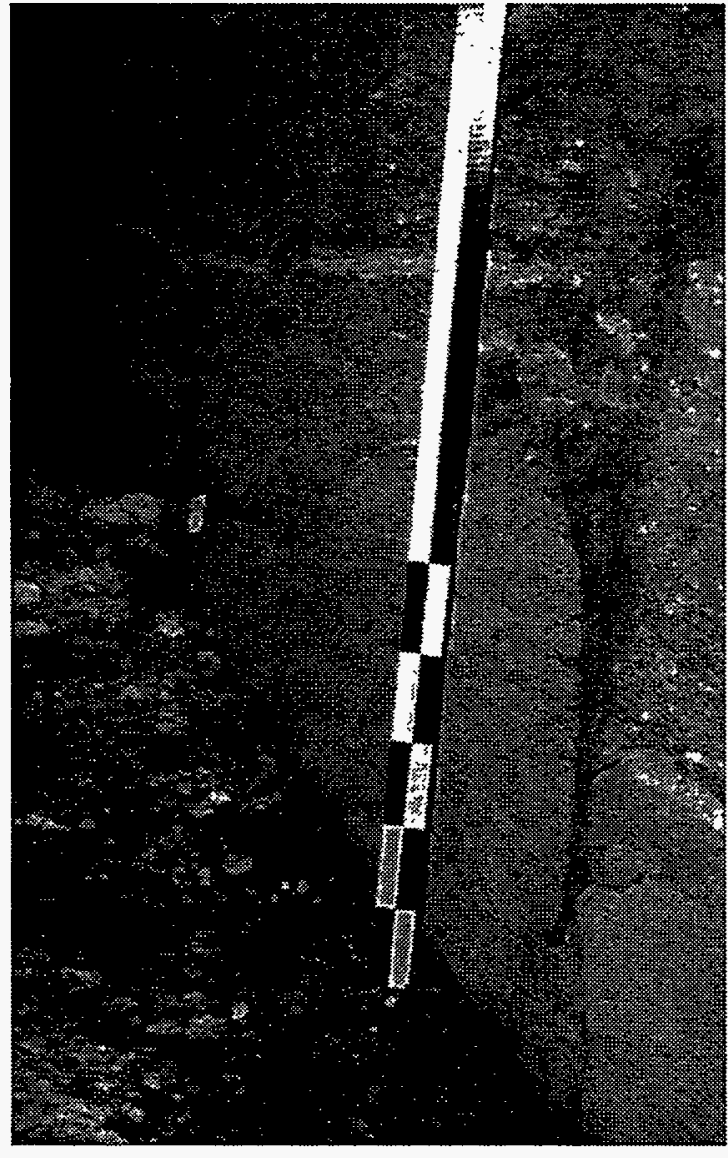

Fig. 19. Photograph of trench W5 fault W5-7. Trench location is $39.5 \mathrm{~m}$. White layer is volcanic ash, unit $4 \mathrm{e}$ of Figs. 4 and 5. Small divisions on scale are $10 \mathrm{~cm}$ in length.

was made with a total station (computerized theodolite). All locations where this contact was located in the trenches and along the south sides of Pajarito Mesa and Twomile Mesa were surveyed, and in addition approximate locations of this contact were also surveyed in areas where the contact was obscured by colluvium. The Pajarito Mesa and Twomile Mesa surveys extended about 1.2 and $1.0 \mathrm{~km}$, respectively, and the survey data are shown in Figs. 20 and 21 . Interpretations of faulting, based on these surveys, assume that the surge beds originally had a relatively smooth eastward slope, and that prior deposition of $>100 \mathrm{~m}$ of Tshirege Member units 1, 2, and 3 had erased the small-scale irregularities that existed in the pre-Tshirege topography, particularly any west-facing features.

Of these two mesas, Pajarito Mesa has the most abundant exposure of the contact between Tshirege Member units 3 and 4 , and areas of potential faulting are thus best constrained on Pajarito Mesa. The most striking structural feature is a 100 to $200 \mathrm{~m}$ wide zone of apparent down-to-thewest steps at the eastern end of the transect (Fig. 21a), in the same area as the faulting observed in trench W5 and the exposures of mesa-top alluvium in trenches W3 and W4. Apparent offset of the contact across this zone is about 7 to $9 \mathrm{~m}$, significantly greater than observed in trench W5. In addition, because this zone extends to the easternmost area surveyed, it is possible that more faults are present to the east. The survey data suggest that only part of this fault zone was recognizable in the trenches, and that the mesa-top alluvium is preserved on down-dropped blocks. 
The zone of faulting begins about 30 to $130 \mathrm{~m}$ east of the projected Rendija Canyon fault of Vaniman and Wohletz (1990), but no offset was recognized along the projected trace itself.

Additional evidence of faulting was found at several areas to the west. The most significant is a down-to-the-west step of at least 3 to $4 \mathrm{~m}$ at the western end of the Pajarito Mesa transect (Fig. 21a), where no fault had been previously recognized. Two shallow grabens are also suggested by the survey data, about 50 to $70 \mathrm{~m}$ wide and $2 \mathrm{~m}$ deep.

The survey along the south side of Twomile Mesa also revealed evidence of down-to-thewest faulting in several areas, with estimated offsets of 1 to $4 \mathrm{~m}$, and a possible 1 to $2 \mathrm{~m}$ high horst (Fig. 21b). However, exposures of the contact between Tshirege Member units 3 and 4 are less common than on Pajarito Mesa, and the location and amount of possible offset is therefore less well constrained. No down-to-the-west steps of the magnitude present near Pajarito Mesa trench W5 were observed on Twomile Mesa, suggesting that the zone of faulting identified on Pajarito Mesa occurs east of the surveyed area on Twomile Mesa, east of the Rendija Canyon fault projection of Vaniman and Wohletz (1990).

Small-scale offsets of 0.1 to $0.5 \mathrm{~m}$ were observed along the surge beds at several locations on Pajarito and Twomile Mesas, including the three sites described by Vaniman and Chipera (this report). The locations of the small faults are shown on Fig. 21. Most of these faults were not at the
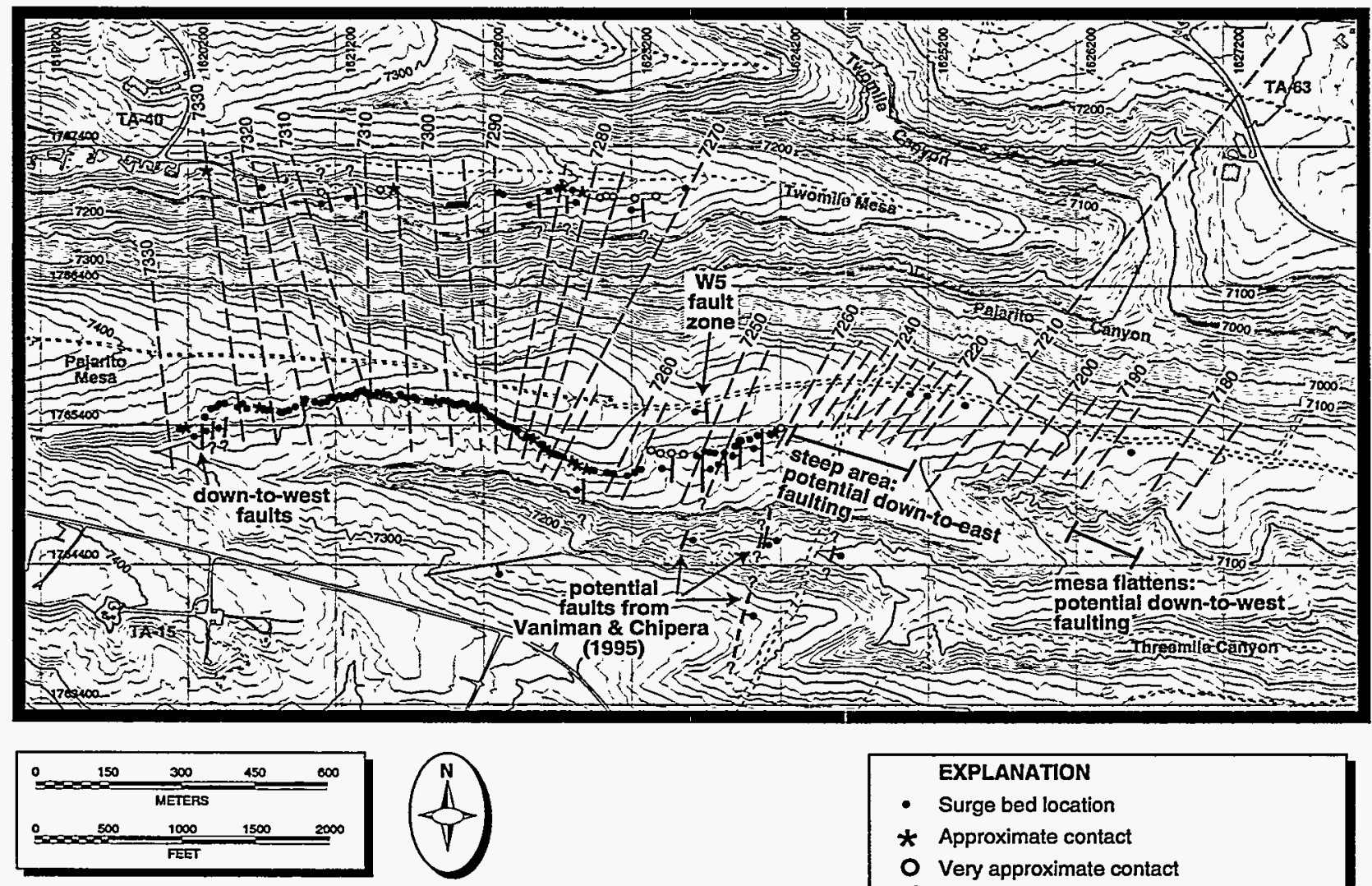

\section{EXPLANATION}

- Surge bed location

* Approximate contact

- Very approximate contact

of Fault, ball on down thrown side

- Apparent structure contour, 5-foot interval

Fig. 20. Map showing surveyed data points on surge bed on Pajarito Mesa and Twomile Mesa, apparent structure contours on top of Tshirege Member unit 3, and inferred fault zones. Most faults are shown schematically with northsouth orientations, although their true orientations are unknown. The structure contours were drawn assuming that there is no significant offset along the contours, and they will thus need revision when fault orientations and offsets are better constrained. Topographic base from FIMAD, showing NAD 83 coordinates and 10-ft contour intervals. 

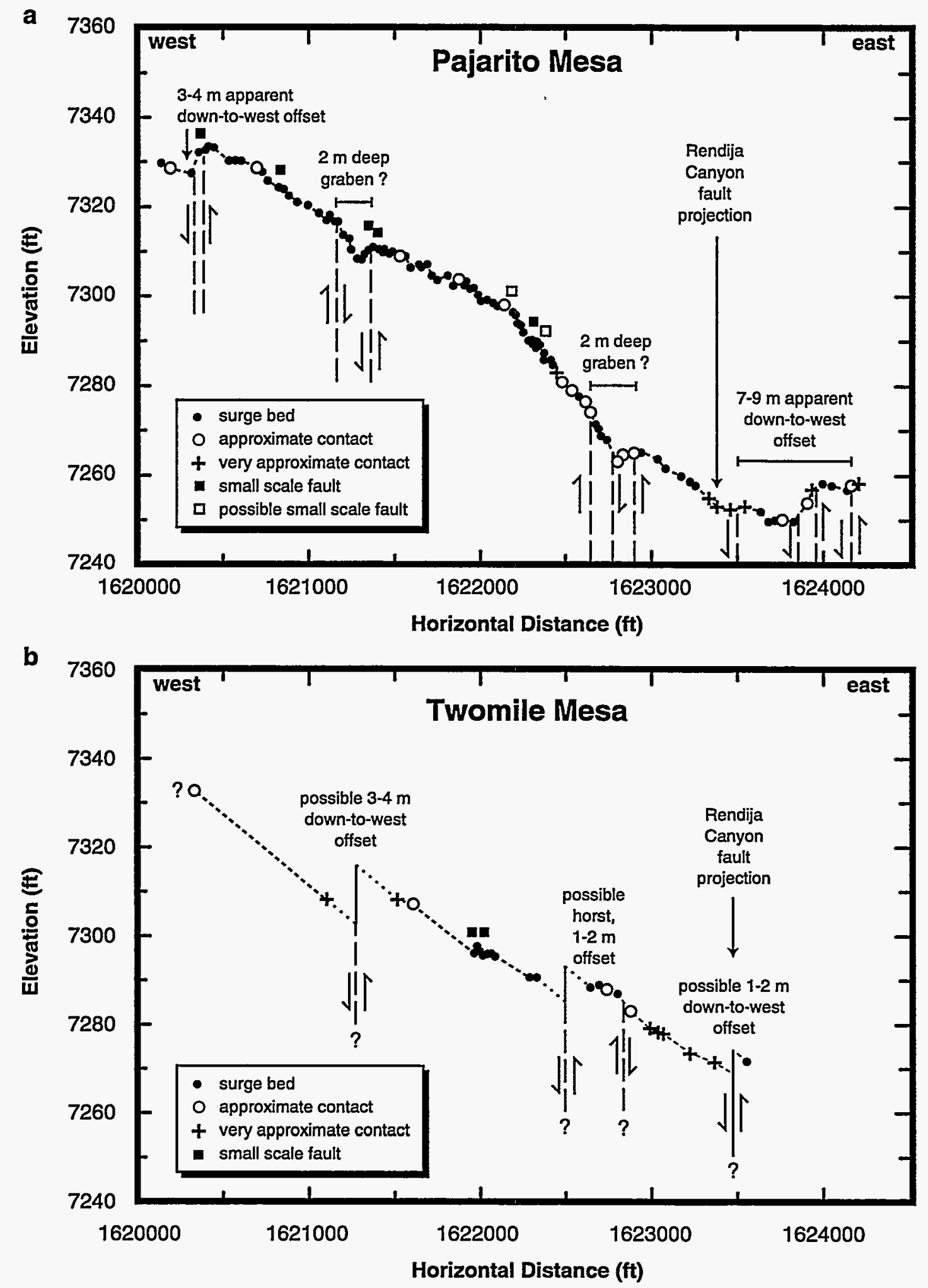

Fig. 21. Elevation of surge beds at the contact of Tshirege Member units 3 and 4, measured along east-west transects on the south sides of a) Pajarito Mesa and b) Twomile Mesa, showing inferred faults with greater than $1 \mathrm{~m}$ displacement and locations of small-scale faults $(0.1-0.5 \mathrm{~m})$ visible in outcrop. Surveyed with total station. Horizontal scale shows NAD 83 coordinates. Projected Rendija Canyon fault from Vaniman and Wohletz (1990). Possible faults on Twomile Mesa are poorly constrained due to limited exposures of surge beds. 
sites where larger-scale faulting was identified or inferred. This suggests that the small-scale faults may simply reflect minor secondary faulting between more pronounced fault traces. Similar distributed small-scale faulting has been identified at many sites along Mesita del Buey at TA-54 (D. E. Broxton, J. S. Carney, S. L. Reneau, unpublished data, 1993).

The presence of down-to-the-east faulting, as inferred by Vaniman and Chipera (this report) nearby in Threemile Canyon (Fig. 20), is suggested by an examination of variations in the top of bedrock as exposed in the trenches. Surge beds are exposed at three locations in trenches $\mathrm{E} 1$, $E 2$, and E6, indicating that the top of bedrock in the eastern trenches probably approximately marks the top of Tshirege Member unit 3. For a distance of over $400 \mathrm{~m}$ between the E2 and E6 surge locations, including part of the southern projection of the Guaje Mountain fault zone (Vaniman and Wohletz, 1990), the top of bedrock displays very little variation in slope, suggesting no vertical offset of the top of unit 3 (Fig. 22). However, immediately west the bedrock surface steepens, and the reappearance of surge beds $80 \mathrm{~m}$ to the west suggests the possibility of down-to-the-east faulting with about 2 to $3 \mathrm{~m}$ of offset (Fig. 22). Additional down-to-the-east faulting of 1 to $3 \mathrm{~m}$ within the next $150 \mathrm{~m}$ to the west is suggested by projections of the surveyed surge beds south of the trenches to the trench line (Fig. 23a), although these projections are based on estimated strikes of the Bandelier Tuff and the accuracy of these estimates is unknown, as discussed in the next section.

Although significant uncertainties are inherent in using bedrock profiles to constrain faulting, including the assumption that the original slope of the Bandelier Tuff did not change abruptly over short distances, the data on bedrock slopes presented here are consistent with the down-to-theeast faulting inferred by Vaniman and Chipera (this report) in Threemile Canyon. The estimates of possible down-to-the-east faulting based on bedrock profiles from the trenches are similar to the estimate of $4 \mathrm{~m}$ of cumulative down-to-east offset made by Vaniman and Chipera (this report).

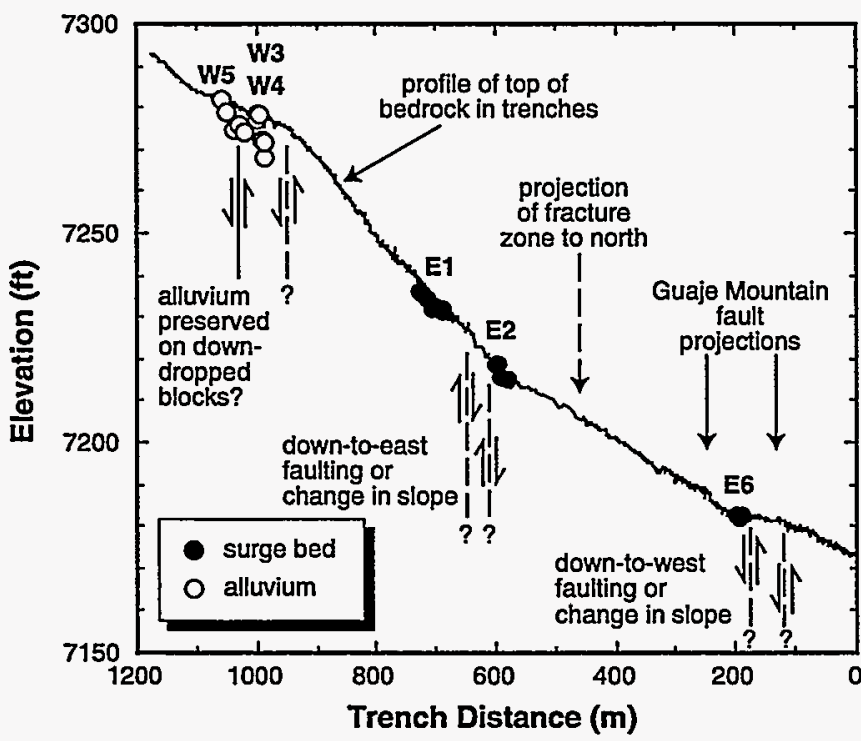

Fig. 22. Profile of top of bedrock in trenches, showing locations of surge beds in trenches E1, E2, and E6, mesa-top alluvium in trenches W3, W4, and W5, and possible faults. Data from trench logs and original survey data of Kolbe et al. (1994). Trench distance measured from east end of trench $\mathrm{E} 8$, with adjustments to total length made to remove overlapping sections. Guaje Mountain fault projections from Vaniman and Wohletz (1990).
Assuming a correlation of the area of steep bedrock exposed from trench E2 to trench W3 with the Threemile Canyon fault zone inferred by Vaniman and Chipera (this report) (Fig. 20) provides an estimated fault zone orientation of N35E to N45E. An apparent N75E fault with about $1 \mathrm{~m}$ of down-to-thesouth offset was located during reconnaissance mapping on the north margin of Threemile Mesa (Fig. 20), also suggesting a strong easterly component to the inferred faults in Threemile Canyon.

\section{Structure Contours}

Structure contours of geologic contacts provide data on the strike and dip of bedrock units, which are useful for evaluating possible subsurface groundwater flow directions and tectonic deformation. The surveyed locations of the surge beds between units 3 and 4 of the Tshirege Member, discussed above, allow structure contours to be estimated for this geologic contact in the vicinity of Pajarito Mesa. 


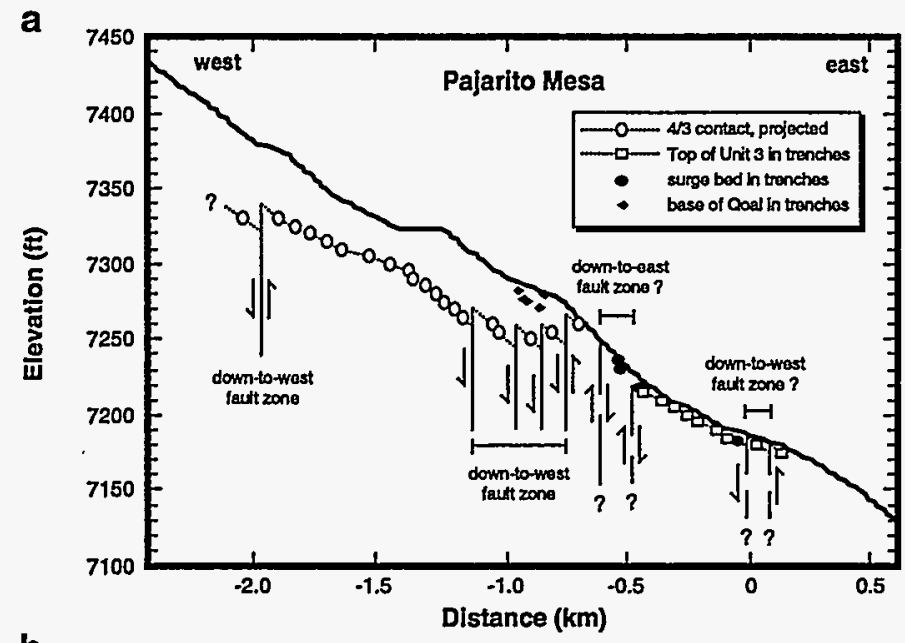

These structure contours are shown on Fig. 20 , and incorporate data on locations of the surge beds on the south sides of Pajarito Mesa and Twomile Mesa, surge locations within the trenches at Pajarito Mesa (Kolbe et al., 1994) and TA-63 to the north (Kolbe et al., 1995), and bedrock elevations in the trenches. They suggest that the strike of the Bandelier Tuff varies from about N10W on the western part of Pajarito Mesa to N35E to the east, and that the dip typically varies from about $1^{\circ}$ to $3^{\circ}$ to the east or southeast. However, because the exact location, orientation, and magnitude of fault offset in this area are not certain, no estimates of offset of the contours were made and they are thus considered here as "apparent" structure contours. Some of the apparent changes in strike and dip of the contact in Fig. 20 probably reflect the presence of faulting between measurement points, whereas others may reflect variations in the original depositional slope of the Bandelier Tuff. These contours will thus need revision as more data become available.

\section{Mesa Profiles}

Fig. 23. Profiles of a) Pajarito Mesa and b) Twomile Mesa, with elevations of surge beds projected to center of mesa, showing inferred zones of faulting. Projections assume strikes of Bandelier Tuff as shown in Fig. 20.

Variations in the gradient of mesas on the Pajarito Plateau have been used to help recognize the location of distributed fault zones which are not clearly expressed by large offsets of Bandelier Tuff stratigraphic units (Vaniman and Wohletz, 1990). Profiles of Pajarito and Twomile Mesas, obtained from FIMAD maps with 2$\mathrm{ft}$ contour intervals, were examined in this study to test the reliability of this use of topographic data and to provide additional constraints on faulting.

Pronounced variations in the slope of Pajarito Mesa occur in the vicinity of the trenches (Fig. 3), and these variations correspond in part to areas of recognized or potential faulting. The area of down-to-the-west faulting seen both in trench W5 and along the south side of Pajarito Mesa corresponds to a relatively gentle part of the mesa (Fig. 23a). Similarly, the steeper part of the mesa top, in the central part of the trenched area, may reflect the apparent down-to-the-east faults within the Bandelier Tuff mapped by Vaniman and Chipera (this report) in Threemile Canyon. However, this steep part of Pajarito Mesa also coincides with the eastern end of Tshirege Member unit 4 , and the variations in slope gradient here may partially reflect the unit 4 flow front.

Variations in the gradient of Pajarito Mesa also suggest additional constraints on the location of the Guaje Mountain fault zone. The slope of the bedrock surface exposed in the trenches is gentlest east of the eastern exposure of surge beds, in trenches E6 and E7 (Fig. 22). By analogy with the gentle mesa top gradient at the trench W5 fault zone, this suggests the presence of additional down-to-the-west faulting of about 2 to $3 \mathrm{~m}$ or more over a $100 \mathrm{~m}$ wide zone. This area 
includes the eastern trace of the Guaje Mountain fault projection of Vaniman and Wohletz (1990) (Fig. 1), and the slope change may provide evidence for the existence of one of their fault traces. However, we cannot exclude the possibility that this slope change instead represents original variations in the slope of the Bandelier Tuff or another previously unrecognized fault that does not connect with the Guaje Mountain fault.

The data obtained from Pajarito and Twomile Mesas indicate that although variations in mesa top gradient can provide evidence for the location and magnitude of faulting, mesa top profiles need to be used cautiously. Prominent steps occur on both mesas in the areas underlain by Tshirege Member unit 4 that do not relate to comparable steps in the underlying surge beds (Fig. 23). These steps apparently represent variations in the original thickness and subsequent erosion of unit 4. At present, we can also not evaluate possible variations in the original slope of the Bandelier Tuff flow units that relate to the underlying paleotopography. However, an examination of variations in mesa top gradient, when combined with mapping of geologic contacts, can still be useful in indicating the most likely sites for faulting and in providing evidence against faulting in other areas.

\section{Fracture Characteristics}

Variations in fracture density and fracture width in roadcuts and on cliffs have been used to infer the location of distributed fault zones on the Pajarito Plateau (Vaniman and Wohletz, 1990; Wohletz, 1995), and similar analyses of fractures exposed in the Pajarito Mesa and TA-63 trenches were made by Kolbe et al. $(1994,1995)$. Measurements of fracture orientation and aperture in the trenches focused on steeply dipping $\left(>45^{\circ}\right)$ "through-going" fractures (those that could be traced from the south to the north trench walls), because these were judged to be the fractures most likely to be produced by faulting or to accommodate tectonic extension. However, the occurrence of small-scale offset on some non through-going fractures in trench W5 (Fig. 5) indicates that this criterion is not entirely valid. All fractures were drawn on the trench logs, allowing an examination of the density of both through-going and non through-going fractures.

At Pajarito Mesa, the average spacing of through-going fractures ranges from $2.2 \mathrm{~m}$ in trenches $E 4$ to $E 8$, to $3.2 \mathrm{~m}$ in trenches $E 1$ to W4 (density of 9.4 to 13.9 fractures per $30 \mathrm{~m}$ ( $100 \mathrm{ft}$ ) of trench, Fig. 24). The average spacing of all steeply-dipping fractures ranges from 0.9 to $1.2 \mathrm{~m}$ (density of 26.4 to 34.5 fractures per $30 \mathrm{~m}$ (100 ft), Fig. 24). For both through-going and non through-going fractures, the average spacing generally increases from west to east. Although there is significant local variation in the density of both through-going and non through-going fractures (Fig. 24), much of this variation does not appear to be related to faulting. For example, the areas of highest fracture density in the eastern trenches, where Tshirege Member unit 3 is exposed, occur in trenches E2 to E5 (Fig. 24) where the uniformity of the bedrock surface gradient (Fig. 22) argues for no vertical offset. In addition, the area of faulting exposed in trench W5 shows a relatively low density of fractures (Fig. 24), suggesting that faulting of the magnitude documented there (1.2 $\mathrm{m}$ ) is insufficient to increase the fracture density significantly. The area of possible down-to-theeast faulting between the trench E1 and E2 surge beds also has a low fracture density. At trench W5, the specific fractures that accommodated faulting also are no wider than average, arguing that the presence or absence of fault movement along specific fractures may be indeterminate in the absence of distinct stratigraphic markers.

The strongest suggestion of a relation between fracture density and faulting is present in trench W3, where high densities of both through-going and non through-going fractures occur in an area where the mesa-top gradient steepens to the east. As discussed above, the presence of old alluvium in the trenches only in the more gently-sloping part of the mesa to the west suggests that these deposits were preferentially preserved on down-dropped blocks associated with a down- 
to-the-west fault zone. The zones of higher fracture density could thus conceivably indicate the location of previously unrecognized faulting, although the available data remain inconclusive. An alternative explanation for the variations in fracture density is that they primarily reflect variations in welding of the tuff. The low fracture density where the contact between Tshirege Member unit 3 and unit 4 is exposed in trench E1, and also where clasts of the surge beds are present in a rubble zone in trenches E2 and E6 (Fig. 24), may be due to a reduced fracture density at the nonwelded top of unit 3. This in turn suggests that most fractures within unit 3 do not continue upward into unit 4 , but instead die out within the uppermost part of unit 3. The relatively low fracture density in trench W5 in the vicinity of the fault zone may similarly reflect exposure of a higher, less-welded level of unit 4, protected from erosion where it was preserved on a down-faulted block (e.g., Fig. 23a).

The fracture data from the Pajarito Mesa trenches are generally consistent with the data of Vaniman and Chipera (this report) from mesa-penetrating fractures at the base of Tshirege Member unit 3 , in that average fracture spacing increases from west to east and no zones of significantly higher fracture density were identified. However, the average spacing of mesa-penetrating fractures varies from 4.1 to $6.1 \mathrm{~m}$ from the west to the east along Pajarito Mesa (Vaniman and Chipera, this report), or about $40 \%$ to $60 \%$ greater than the values obtained by Kolbe et al. (1994) for throughgoing fractures. This suggests that about one third of the through-going fractures do not penetrate completely through the more welded tuff units and into the underlying nonwelded tuff.

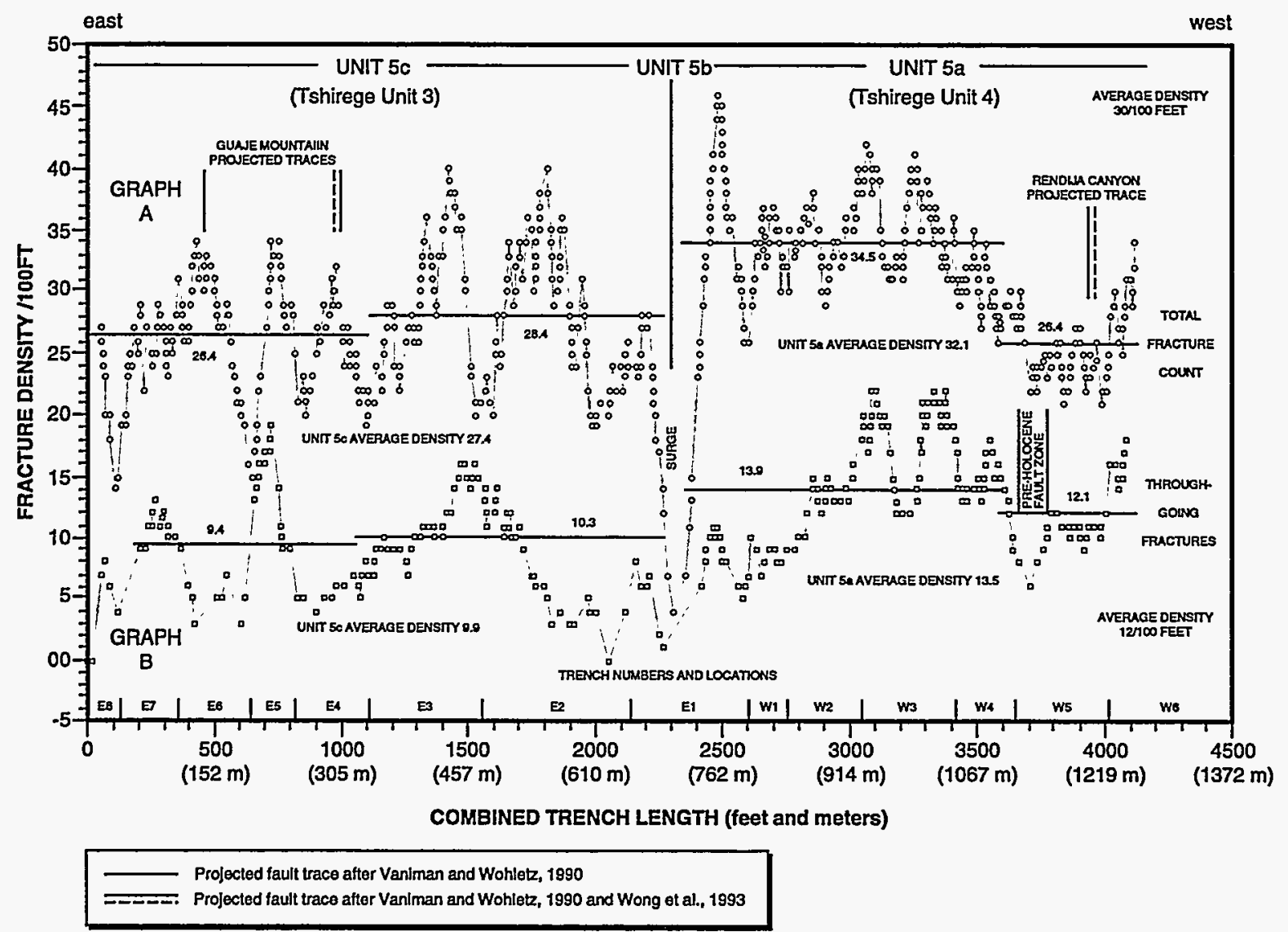

Fig. 24. Fracture density variations in trenches; from Kolbe et al. (1994). 
The average width of through-going fractures in the Pajarito Mesa trenches is about $2 \mathrm{~cm}$ (Kolbe et al., 1994), and is similar to average fracture widths of about 1 to $2 \mathrm{~cm}$ in the TA-63 trenches (Kolbe et al., 1995). Average fracture widths in the Pajarito Mesa trenches are generally slightly higher to the east, in Tshirege Member unit 3, although the measurements of Vaniman and Chipera (this report) indicated that fracture width at the base of Tshirege unit 3 was instead higher to the west. This difference between fracture width measured in the trenches and along cliffs, in combination with the variations seen within the cliff survey, suggests that fracture width may in part vary with welding of the tuff. Specifically, the easterly decrease in fracture width observed by Vaniman and Chipera (this report) may be related to the easterly decrease in welding within Tshirege Member unit 3, and the westerly decrease in fracture width observed by Kolbe et al. (1994) may similarly be related to the fact that Tshirege unit 4 is less welded than unit 3 at Pajarito Mesa (Broxton et al., this report).

It is also notable that the trend of increasing fracture widths to the east, as measured in the trenches, is opposite the general trend of increasing fracture clensity to the west that was discussed above (Kolbe et al., 1994). These data can be combined into a cumulative fracture opening per length of trench (fracture density multiplied by average opening), to show the total percentage of the tuff occupied by through-going fractures and to allow an examination of spatial variations in these percentages (Fig. 25). As measured over $15 \mathrm{~m}$ sections of trench, such percentages show great local variability, ranging from $0 \%$ to $2.6 \%$ and averaging about $0.6 \%$ (Fig. 25a). Much of this variability may be an artifact of the size of the measurement interval, and general patterns can be more easily seen by averaging the data over longer sections of trench (Fig. 25b).

As averaged over $60 \mathrm{~m}$ sections, fracture percentages range up to $1.4 \%$ and show significant gross variability that in part reflects the fracture density variations shown in Fig. 24 (Fig. 25b). The lowest fracture percentages occur in trenches E1, E2, and E6 in the vicinity of the surge beds, again suggesting that fractures have generally not propagated through this stratigraphic contact. The highest fracture percentages occur in trenches W3, E7, and where trenches E2 and E3 overlap (Fig. 25b). These areas of high fracture percentages may in part reflect tectonic extension associated with fault zones, but natural stratigraphic variability in fracture characteristics cannot be ruled out. Specifically, the trench W3 area in part includes the fault zone surveyed on the south side of the mesa (Fig. 21a), and the trench E7 area includes the gentle part of Pajarito Mesa near the Guaje Mountain fault projection where possible down-to-the-west faulting is indicated (Figs. 22 and 23a). In contrast, the higher percentage of the trench walls occupied by through-going fractures at the ends of trenches E2 and E3 (Fig. 25b) are in an area of relatively uniform bedrock slope where no evidence for faulting has been recognized (Figs. 22 and 23a). The causes of these variations in fractures are thus not completely clear.

\section{Evaluation of Fault Projections at Pajarito Mesa}

An interpretation of subsurface data beneath the Pajarito Plateau by Dransfield and Gardner (1985) suggested that southern projections of the north-south trending Guaje Mountain and Rendija Canyon faults occurred in the pre-Bandelier rocks beneath Pajarito Mesa. Later work by Vaniman and Wohletz (1990), involving reconnaissance mapping, measurements of fracture density in roadcuts, and interpretation of geomorphic features such as canyon-wall embayments, projected both faults across Pajarito Mesa within the Bandelier Tuff. Vaniman and Wohletz (1990) interpreted that these faults were expressed as zones of intense fracturing $300 \mathrm{~m}$ or more wide in roadcuts to the north, with small-scale offset occurring on many individual fractures. More recently, interpretation 
a

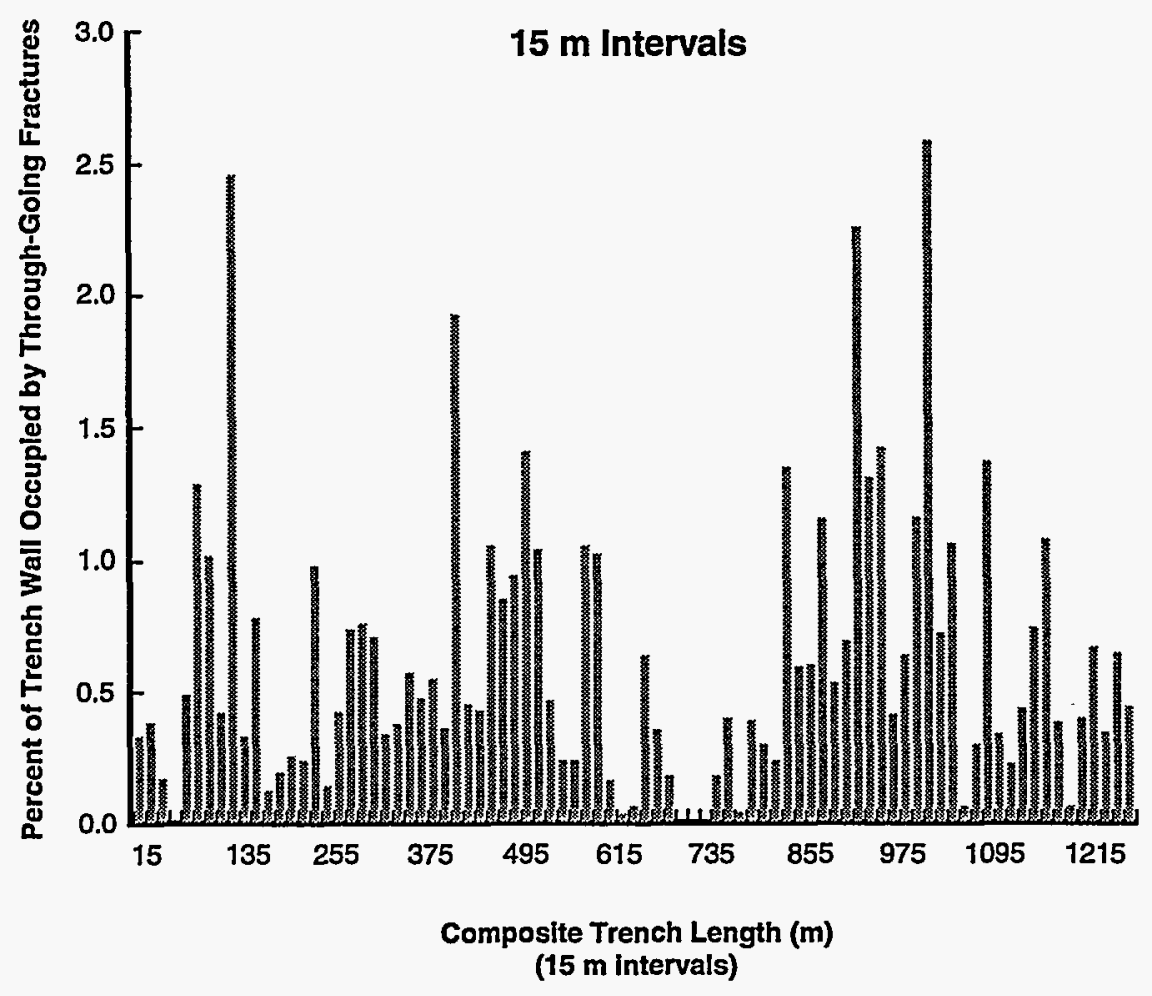

b

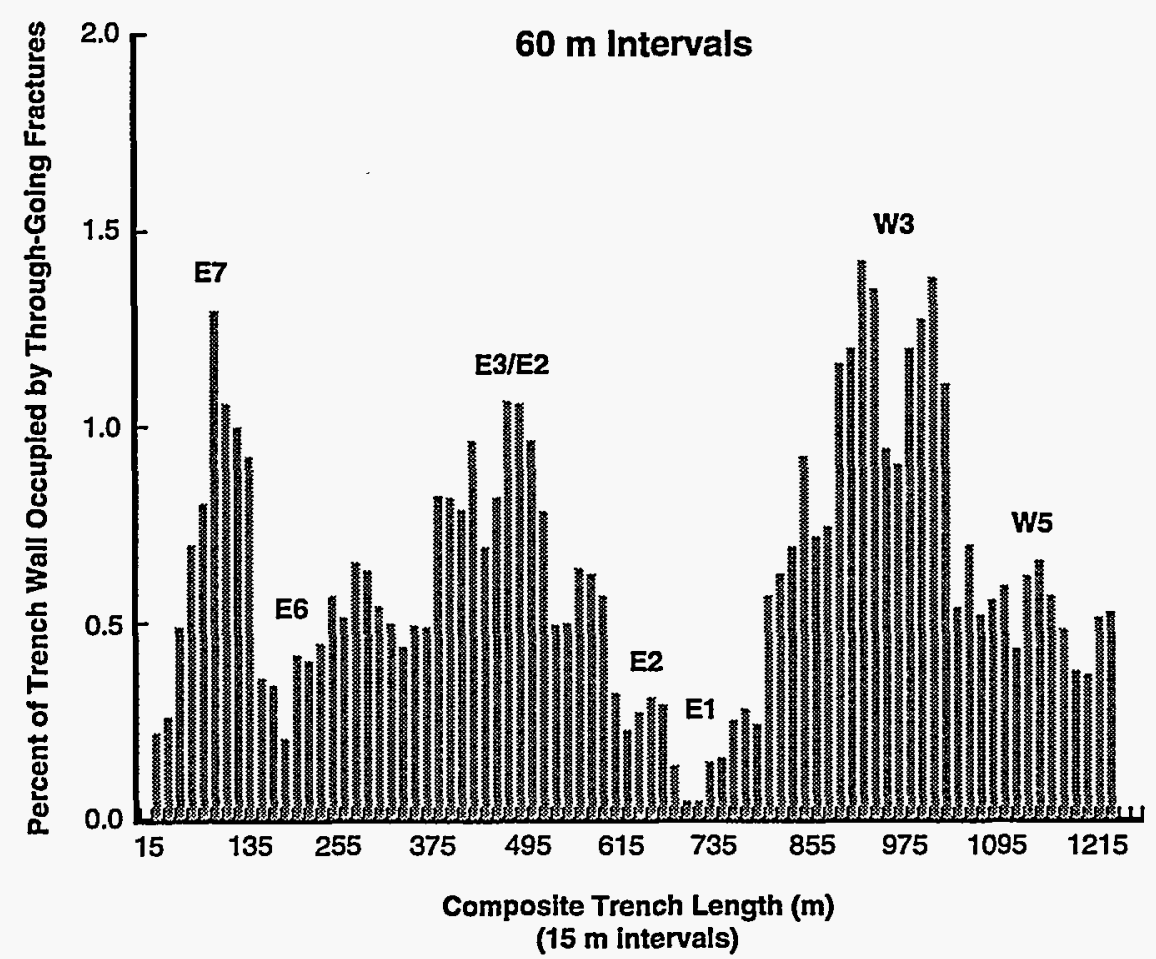

Fig. 25. Variations in percentage of trench walls occupied by through-going fractures, plotted for 15-m intervals. Values represent average fracture width multiplied by fracture density and divided by interval length. a) Percentage for each $15-\mathrm{m}$ interval. b) Percentage for $60-\mathrm{m}$ intervals, calculated as a running average with $15-\mathrm{m}$ increments. Data from Kolbe et al. (1994). 
of aerial photograph lineaments by Wong et al. $(1993,1995)$ concurred with the possible southern projection of these faults across Pajarito Mesa, although conclusive evidence for faulting had not been recognized this far south prior to this study.

The geologic mapping and exploratory trenching conducted as part of MWDF site characterization activities (Kolbe et al., 1994; Vaniman and Chipera, this report; this study) suggest revisions to the previous interpretations of faulting in the vicinity of Pajarito Mesa. No increase in fracture density across the projections of the fault zones was seen (Fig. 24), and surveying of surge beds revealed no offset of the Bandelier Tuff along the Rendija Canyon fault projection (Fig. 21). Faulting is present in the vicinity of the Rendija Canyon fault projection, shown by both trench logging and surface mapping, but may be more complicated than previously inferred. Specifically, both down-to-the-west and down-to-the-east faulting is suggested (Figs. 22 and 23). These fault zones may intersect along the south margin of Pajarito Mesa, bounding a wedge-shaped horst block, although their relation to each other is not certain. The relation of these fault zones to the north-south trending Rendija Canyon fault is also uncertain. Although the down-to-the-west fault zone exposed in trench W5 could be a southern continuation of the Rendija Canyon fault (Kolbe et al., 1994; Wong et al., 1995), it is also possible that it is part of a previously unrecognized fault zone. The northern and southern extents of the faults that cross Pajarito Mesa near the western part of the proposed MWDF and their paleoseismic history have not been determined, although the trench studies demonstrate that they have not moved in the last 50-60 ka.

The question of whether a southern projection of the Guaje Mountain fault crosses Pajarito Mesa within the Bandelier Tuff is also unresolved. Although no significant increases in fracture density occur across its projection either at Pajarito Mesa or north at TA-63 (Kolbe et al., 1994, 1995), the lack of increases in fracture density at areas of recognized faulting in trench W5 indicates that fracture characteristics alone can be inconclusive. A decrease in bedrock gradient in the eastern area trenched on Pajarito Mesa (Fig. 22), in an area with a high percentage of fractures (Fig. 25b) suggests the possibility of down-to-the-west faulting in the Bandelier Tuff, perhaps associated with the Guaje Mountain fault zone. Alternatively, the apparent decrease in gradient could reflect primary variations in the dip of the Bandelier Tuff, and the southern extent of the Guaje Mountain fault thus remains uncertain.

\section{ACKNOWLEDGMENTS}

This work was funded by the Los Alamos National Laboratory Environmental Restoration Program as part of site characterization activities for the proposed Mixed Waste Disposal Facility and as part of the Framework Studies program within the Earth Science Technical Team. Work by Woodward-Clyde Federal Services was performed under subcontracts 9-XV3-6509F and 9-XV3$6509 \mathrm{~F}-1$, and we thank Christine Othart for administration of these contracts. Jackie Bott, Clark Fenton, Andy Gorton, Bill Loskutoff, Janet Sawyer, Sharon Sullivan, and Ivan Wong of WoodwardClyde Federal Services and Colleen Haraden of William Lettis and Associates contributed to the trench logging and preparation of the trench report. The authors thank Paul Aamodt, Darrell Bultman, Bob Gillis, and Chuck Harrington for their support; the personnel of DX-10 for access arrangements; Steve Forman, Eric McDonald, and Paula Watt for their insights into field relations of Pajarito Mesa soils; Steve Forman for thermoluminescence analyses; Steve Hoagland and Bev Larson for archaeological advice; Dave Broxton for discussion about the pumice contained within the mesa-top alluvium; Marcia Jones, Doug Walther and Liz Zeiler with FIMAD for GIS support; and Barry Moore and Tony Garcia for drafting support. Jim McCalpin of GEO-HAZ Consultants provided valuable comments during a field review of the trench exposures, and Peggy Reneau of IT Corporation and Jim McCalpin provided helpful reviews of the original trench report. The authors also thank Dave Broxton, Karen Carter, and Eric McDonald for reviews of this report. 


\section{REFERENCES}

Bailey, R. A., Smith, R. L., and Ross, C. S., 1969, Stratigraphic nomenclature of volcanic rocks in the Jemez Mountains, New Mexico: in Contributions to Stratigraphy, U. S. Geological Survey Bulletin 1274-P, p. 1-18.

Bowen, B. M., 1990, Los Alamos Climatology: Los Alamos National Laboratory Report LA-11735MS, 254 p.

Broxton, D. E., Vaniman, D., Byers, F. M., Jr., Chipera, S. J., Kluk, E. C., and Warren, R. G., 1995, Stratigraphy, mineralogy and chemistry of bedrock tuffs at Pajarito Mesa: this report.

Cordell, L. S., 1979, Cultural Resources Overview of the Middle Rio Grande Valley, New Mexico: U. S. Government Printing Office, Washington, D.C., 198 p.

Cordell, L. S., 1984, Prehistory of the Southwest: Orlando, Academic Press, 409 p.

Dransfield, B. J., and Gardner, J. N., 1985, Subsurface geology of the Pajarito Plateau, Española Basin, New Mexico: Los Alamos National Laboratory Report LA-10455-MS, 15 p.

Forman, S. L., Smith, R. P., Hackett, W. R., Tullis, J. A., and McDaniel, P. A., 1993, Timing of glaciations in the western United States based on the age of late Pleistocene loess on the eastern Snake River Plain, Idaho: Quaternary Research, v. 40, p. 30-37.

Gardner, J. N., Baldridge, W. S., Gribble, R., Manley, K., Tanaka, K., Geissman, J. W., Gonzalez, M., and Baron, G., 1990, Results from Seismic Hazards Trench \#1 (SHT-1), Los Alamos Seismic Hazards Investigations: Los Alamos National Laboratory Memorandum EES1SH90-19, Los Alamos, New Mexico.

Hoagland, S., Lakatos, S., Schillaci, M., and Albertson, V., 1994, Resource Conservation and Recovery Act, Mixed Waste Disposal Facility, Cultural Resource Survey Report: unpublished draft report, Los Alamos National Laboratory, Los Alamos, New Mexico.

Izett, G. A., and Obradovich, J. D., 1994, $40 \mathrm{Ar} /{ }^{39} \mathrm{Ar}$ age constraints for the Jaramillo Normal Subchron and the Matuyama-Brunhes geomagnetic boundary: Journal of Geophysical Research, v. 99 (B2), p. 2925-2934.

Kelson, K. I., Hemphill-Haley, M. A., Wong, I. G., Gardner, J. N., and Reneau, S. L., 1993, Paleoseismic investigations of the Pajarito fault system, western margin of the Rio Grande rift near Los Alamos, NM: Geological Society of America Abstracts With Programs, v. 25, no. 5 , p. 61-62.

Kolbe, T., Sawyer, J., Gorton, A., Olig, S., Simpson, D., Fenton, C., Reneau, S., Carney, J., Bott, J., and Wong, I., 1994, Evaluation of the Potential for Surface Faulting at the Proposed Mixed Waste Disposal Facility, TA-67: unpublished report, Woodward-Clyde Federal Services, Oakland, California, 3 volumes.

Kolbe, T., Sawyer, J., Springer, J., Olig, S., Reneau, S., Hemphill-Haley, M., and Wong, I., 1995, Evaluation of the Potential for Surface Faulting at TA-63: unpublished report, WoodwardClyde Federal Services, Oakland, California.

Laughlin, A. W., WoldeGabriel, G., and Dethier, D., 1993, Preliminary Report, FY93, Volcanic Stratigraphy of the Pajarito Plateau: unpublished report, Los Alamos National Laboratory, Los Alamos, New Mexico.

Longmire, P., Reneau, S., Watt, P., McFadden, L., Gardner, J., Duffy, C., and Ryti, R., 1995, Natural Background Geochemistry, Geomorphology, and Pedogenesis of Selected Soil Profiles and Bandelier Tuff, Los Alamos, New Mexico, 1995: Los Alamos National Laboratory Report LA-12913-MS, Los Alamos, New Mexico (in press).

Marvin, R. F., and Dobson, S. W., 1979, Radiometric ages: Compilation B, U. S. Geological Survey: Isochron West, v. 26, p. 25. 
Miyachi, M., Izett, G. A., Naeser, C. W., Naeser, N. D., and Andreissen, P. A. M., 1985, Zircon fission-track ages on some volcanic rocks and pyroclastic flow deposits of the Jemez Mountains, New Mexico: Bulletin Volcanological Society of Japan, v. 30, p. 90.

Nelson, A. R., 1992, Discordant ${ }^{14} \mathrm{C}$ ages from buried tidal-marsh soils in the Cascadia subduction zone, southern Oregon coast: Quaternary Research, v. 38, p. 74-90.

Nyhan, J. W., Hacker, L. W., Calhoun, T. E., and Young, D. L., 1978, Soil Survey of Los Alamos County, New Mexico: Los Alamos Scientific Laboratory Informal Report LA-6779-MS, 102 p.

Orcutt, J. D., 1991, Environmental variability and settlement changes on the Pajarito Plateau, New Mexico: American Antiquity, v. 56, p. 315-332.

Plafker, G., LaJoie, K. R., and Rubin, M., 1992, Determining recurrence intervals of great subduction zone earthquakes in southern Alaska by radiocarbon dating: in Taylor, R. E., Long, A., and Kra, R. S., eds., Radiocarbon After Four Decades: An Interdisciplinary Perspective: New York, Springer-Verlag, p. 436-453.

Reneau, S. L., 1995, Geomorphic studies at DP Mesa and vicinity: in Broxton, D. E., and Eller, P. G., eds., Earth Science Investigations for Environmental Restoration--Los Alamos National Laboratory Technical Area 21: Los Alamos National Laboratory Report LA-12934-MS, p. 65-92.

Scott, E. M., Aitchison, T. C., Harkness, D. D., Cook, G. T., and Baxter, M. S., 1990, An overview of all three stages of the international radiocarbon comparison: Radiocarbon, v. 32, p. 309319.

Self, S., Kircher, D. E., and Wolff, J. A., 1988, The El Cajete Series, Valles caldera, New Mexico: Joumal of Geophysical Research, v. 93 (B6), p. 6113-6127.

Self, S., Wolff, J. A., Spell, T.L., Skuba, C. E., and Morrissey, M. M., 1991, Revisions to the stratigraphy and volcanology of the post-0.5 Ma units and the volcanic section of VC-1 core hole, Valles caldera, New Mexico: Journal of Geophysical Research, v. 96 (B3), p. 4107-4116.

Spaulding, W. G., Leopold, E. B., and Van Devender, T. R., 1983, Late Wisconsin paleoecology of the American Southwest: in Porter, S. C., ed., Late-Quaternary Environments of the United States, Vol. l, The Late Pleistocene, p. 259-293.

Steen, C. R., 1977, Pajarito Plateau Archaeological Survey and Excavations: Los Alamos Scientific Laboratory Report LASL-77-4, $70 \mathrm{p}$.

Steen, C. R., 1982, Pajarito Plateau Archaeological Survey and Excavations, II: Los Alamos National Laboratory Report LA-8860-NERP, 60 p.

Stuart, D. E., and Gauthier, R. P., 1981, Prehistoric New Mexico: Background for Survey. Albuquerque, University of New Mexico Press, $459 \mathrm{p}$.

Stuiver, M., and Reimer, P. J., 1993, Extended $14 \mathrm{C}$ data base and revised CALIB $3.014 \mathrm{C}$ age calibration: Radiocarbon, v. 35, p. 215-230.

Toyoda, S., Goff, F., Ikeda, S., and Ikeya, M., 1995, ESR dating of quartz phenocrysts in the EI Cajete and Battleship Rock Members of Valles Rhyolite, Valles caldera, New Mexico: Journal of Volcanology and Geothermal Research (in press).

Van Devender, T. R., Thompson, R. S., and Betancourt, J. L., 1987, Vegetation history of the deserts of southwestern North America; The nature and timing of the Late WisconsinHolocene transition, in Ruddiman, W. F., and Wright, H. E., Jr., eds., North America and adjacent oceans during the last deglaciation: Boulder, Colorado, Geological Society of America, The Geology of North America, v. K-3, p. 323-352.

Vaniman, D., and Chipera, S., 1995, Mesa-penetrating fractures, fracture mineralogy, and projected fault traces at Pajarito Mesa: this report. 
Vaniman, D., and Wohletz, K., 1990, Results of geological mapping/fracture studies: TA-55 area: Los Alamos National Laboratory Memorandum EES1-SH90-17, Los Alamos, New Mexico, $23 \mathrm{p}$.

Wischmeier, W. H., and Smith, D. D., 1978, Predicting rainfall erosion losses: Aguide to conservation planning: U. S. Department of Agriculture Handbook 537, $58 \mathrm{p}$.

Wohletz, K., 1995, Measurement and analysis of rock fractures in the Tshirege Member of the Bandelier Tuff along Los Alamos Canyon adjacent to TA-21: in Broxton, D. E., and Eller, P., G., eds., Earth Science Investigations for Environmental Restoration--Los Alamos National Laboratory Technical Area 21: Los Alamos National Laboratory Report LA-12934-MS, p. 19-31.

Wong, I., Hemphill-Haley, M., Kolbe, T., Green, R., Bott, J., Kanakari, H., Kelson, K., Haraden, C., Gardner, J., House, L., Reneau, S., Keller, D., Silva, W., and Stark, C., 1993, Deterministic and probabilistic seismic hazard evaluation of the Los Alamos National Laboratory: Proceedings of Fourth DOE Natural Phenomena Hazards Mitigation Conference, Atlanta, GA, DOE Report CONF-9310102, v. 1, p. 258-267.

Wong, I., Kelson, K., Olig, S., Kolbe, T., Hemphill-Haley, M., Bott, J., Green, R., Kanakari, H., Sawyer, J., Silva, W., Stark, C., Haraden, C., Fenton, C., Unruh, J., Gardner, J., Reneau, S., and House, L., 1995, Seismic Hazards Evaluation of the Los Alamos National Laboratory: unpublished report, Woodward-Clyde Federal Services, Oakland, California, 3 volumes. 
D 


\title{
MESA-PENETRATING FRACTURES, FRACTURE MINERALOGY, AND PROJECTED FAULT TRACES AT PAJARITO MESA
}

\author{
by \\ David Vaniman and Steve Chipera \\ Geology/Geochemistry Group \\ Los Alamos National Laboratory
}

\begin{abstract}
Earlier studies have suggested that the traces of the Rendija Canyon and Guaje Mountain faults project across Pajarito Mesa, based on the distributions of fracture abundances and apertures on mesas to the north. However, the only direct evidence for faulting found at Pajarito Mesa is near the Rendija Canyon fault projection, as fault offsets observed in trench TW5. Offsets in outcrop were found farther to the west, about $490 \mathrm{~m}$ (1600 ft) from a potential Mixed Waste Disposal Facility (MWDF) boundary. These fault offsets, generally down to the west where closest to the potential MWDF in trench TW5, may be related to the southern extension of the Rendija Canyon fault. Inferred fault offsets in the bottom of Threemile Canyon, just south of Pajarito Mesa, have an opposite sense of apparent offset (down to the east). These inferred fault offsets in the canyon bottom may instead represent irregular flow-unit topography within the tuff, unrelated to faulting, or they may represent secondary faulting related to a section of steeply east-dipping tuff stratigraphy to the NE on top of Pajarito Mesa. Regardless of these various interpretations, the absence of any evidence for Holocene offset in faults at the mesa top indicates that the MWDF site is not compromised by young faulting.
\end{abstract}

Studies of mesa-penetrating fractures along the southern edge of Pajarito Mesa show no concentration of abundant fractures or increase in fracture apertures associated with the previously inferred projections of the Rendija Canyon or Guaje Mountain faults. Fracture apertures increase to the west where fracture orientations are strongly oriented $N 17^{\circ} \mathrm{E} \pm 15^{\circ}$. This interval of relatively wide and oriented fractures represents the potential MWDF locality.

Clay minerals are formed in soils at the mesa top and transported downward into deeper fractures. With few exceptions, clay transport is effectively stopped where these fractures pass into the nonwelded tuff at the mesa base, where such transport is diverted laterally over short distances into the more permeable layers of nonwelded tuff rather than moving farther downward. The mineralogic data suggest that fracture transport just above the nonwelded tuff can discharge fluids at the mesa base, but association of clays with halite indicates that evaporative concentration may prevent many solutes from escaping from the mesa. However, the evidence for this evaporation effect has been found only in those parts of the mesa to the east of the potential MWDF. 


\section{INTRODUCTION}

Pajarito Mesa is the candidate locality for development of a Los Alamos National Laboratory Mixed Waste Disposal Facility (MWDF). The locations of waste pits and waste processing facilities at Pajarito Mesa may be constrained in part by the locations of fault traces. The provisions of 40 CFR 270 (EPA Administered Permit Programs: The Hazardous Waste Permit Program) in 270.14(b)(11)(ii) call for investigations to either (1) discount any evidence for Holocene faulting (i.e., any displacement within the past 11,000 years) or (2) provide the necessary information to place treatment, storage, or disposal facilities at least $60 \mathrm{~m}(200 \mathrm{ft})$ from faults if Holocene

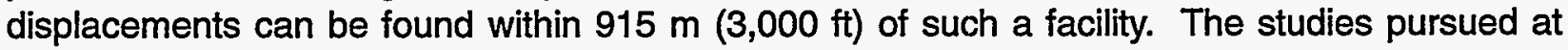
Pajarito Mesa address item (1) directly through trenching to investigate any soil-zone offsets. Trenching and trench mapping have been completed (Kolbe et al., 1994). Item (2) has been addressed by preparation of a detailed geologic map at a scale of 1:1200, including measured or inferred offsets of bedrock units (exclusive of trench exposures) and the mapped locations and orientations of major fractures along the well-exposed southern margin of Pajarito Mesa. This map permits fracture analysis, for future comparison with trench and pit data on the mesa top, to assess the possibility of fracture transport of contaminants and to examine fracture distributions and apertures for any evidence of faulting. An earlier study, centered around TA-55, projected the traces of the Rendija Canyon and Guaje Mountain fault zones to the south and across Pajarito Mesa, based on zones of disturbance inferred from the abundances and apertures of fractures on mesas to the north (Vaniman and Wohletz, 1990). These inferred fault projections are included in the map made for this study of Pajarito Mesa. A copy of this map, in three sections, is included with this report (Plates 1-3).

Pajarito Mesa is bounded on the north by Pajarito Canyon and on the south by Threemile Canyon. The mesa has been tentatively divided into three possible sites for waste disposal; these sites are designated (from west to east) as PS-1, PS-2, and PS-3 (Fig. 1). Respectively, these sites are approximately within TA-67, TA-15, and TA-36 in the administrative subdivisions of Pajarito Mesa. Current emphasis is on the close examination of PS-1 as a candidate for earliest development, and the proposed facility outline is shown in blue on Plates 1 and 2.

The discussion that follows summarizes the data on (1) fault offsets and traces, (2) fracture distributions, orientations, and apertures, and (3) fracture mineralogy and petrography as they pertain to past fracture transport of alteration products ancl potential future fracture transport of contaminants.

\section{FAULT OFFSETS AND TRACES}

\section{Observable Fault Offsets in Outcrop}

With the exception of faults mapped in trench TW5 (Reneau et al., this volume) the only observable offsets that have been found in the tuff bedrock occur to the west of PS-1 (see Plate 1). These offsets are visible at the base of unit 4 , where surge beds provide a mappable horizon within the Tshirege Member of the Bandelier Tuff (the designation of unit 4 is defined in this report; see section on site stratigraphy, petrography, and mineralogy by Broxton et al., this report). The measured offsets are of moderate amount (23 to $30 \mathrm{~cm}$ or 9-12 in.). Within the area mapped, most of this contact $(\sim 3 / 4)$ is not exposed and other fault offsets of the contact have likely been missed. 


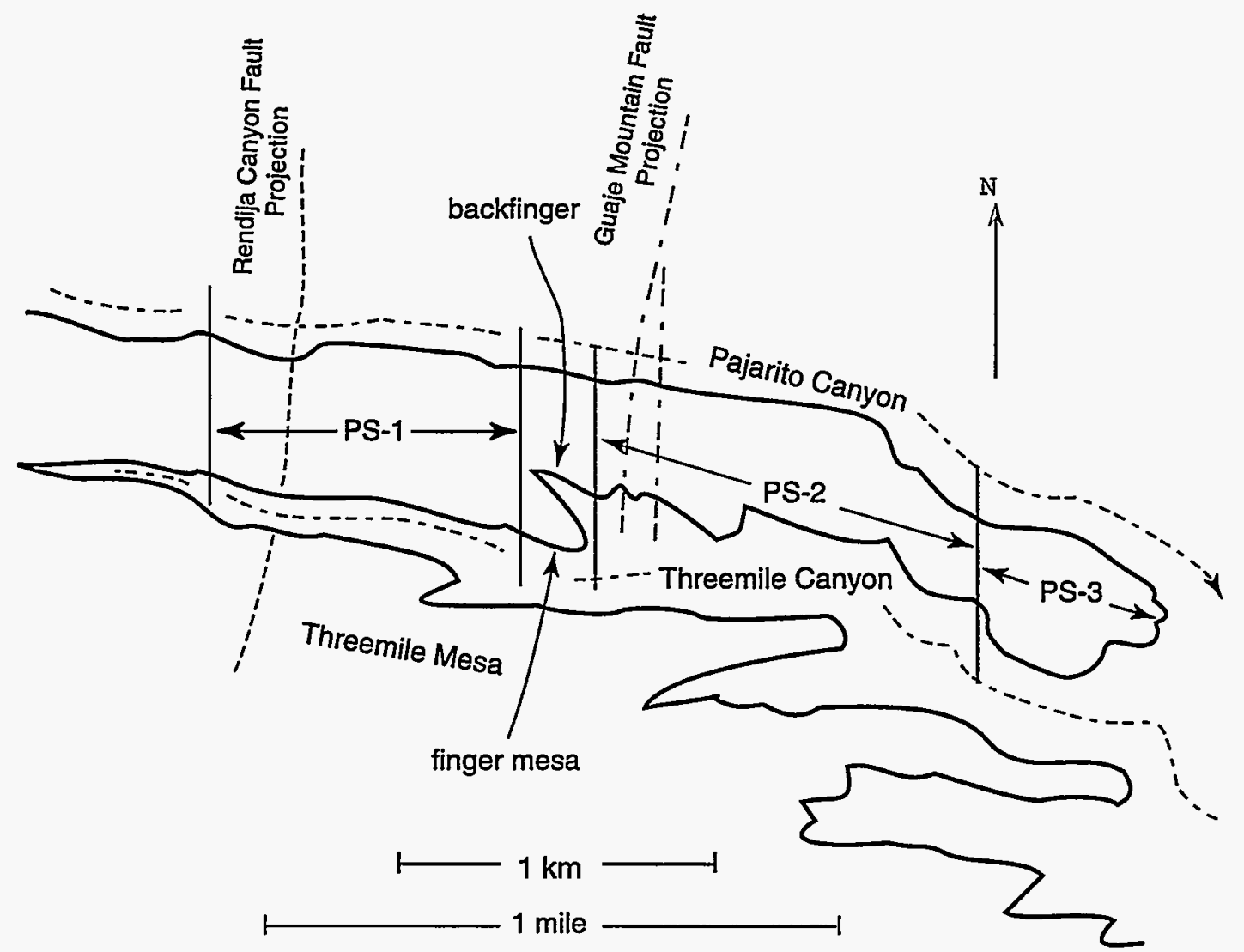

Fig. 1. Sketch map of Pajarito Mesa, showing the approximate boundaries of mesa segments considered as potential sites for mixed-waste disposal (PS-1, PS-2, and PS-3). Locations of the "finger mesa" and "backfinger" are also shown (see Figs. 3, 4, and text section on Fracture Orientations).

Two of the observable offsets are close together and relatively far to the west of PS-1, at the western margin of Plate 1:

- offset at New Mexico State Plane (NMSP) coordinates 1621438 E, 1765538 N. Plane of offset strikes $N 70^{\circ} \mathrm{E}$, dips $86^{\circ} \mathrm{SE}$. Measured displacement is $23 \mathrm{~cm}(9 \mathrm{in})$, down to the SE.

- offset at NMSP coordinates 1621513 E, 1765519 N. Plane of offset strikes N18 W, vertical dip. Inferred displacement is approximately $30 \mathrm{~cm}$ (12 in), down to the SW.

The third measured offset is closer to the western margin of PS-1 (490 m or $1600 \mathrm{ft}$, from the closest part of the potential MWDF facility outline; see Plate 1:

- offset at NMSP coordinates $1622300 \mathrm{E}, 1765331 \mathrm{~N}$. Plane of offset strikes N20ㅌ, dips $77^{\circ} \mathrm{SE}$. Measured displacement is $30 \mathrm{~cm}(12 \mathrm{in})$, down to the SE (this fault is shown on Plate 1).

\section{Possible Fault Offsets in Threemile Canyon}

Possible fault offsets of bedrock have also been found in Threemile Canyon, south of PS-1 between NMSP coordinates $1623450 \mathrm{E}$ and $1624565 \mathrm{E}$; some of these possible offsets are shown at the southern edge of Plate 1. Inference of fault offset is based on anomalous reappearances of 
the contact between moderately-welded tuff unit 2 and the overlying nonwelded interval, upstream of the mapped termination of the unfaulted contact. The mapped termination of the unfaulted contact, which is relatively flat-lying (dip $\sim 1.2^{\circ} \mathrm{E}$ ), is at an elevation of $7094 \mathrm{ft}$; the contact reappears upstream at elevations of approximately $7100 \mathrm{ft}, 7115 \mathrm{ft}$, and $7130 \mathrm{ft}$. These stepwise changes in elevation suggest cumulative offsets, consistently down to the east, spread across a possible fault zone about $335 \mathrm{~m}(1100 \mathrm{ft})$ wide.

If these stepped recurrences of the unit $2 /$ nonwelded tuff contact are due to faulting, then an approximate cumulative fault offset can be estimated for this $335 \mathrm{~m}$ (1100 ft) zone. Where this contact dips continuously to the east, without apparent offset, it has a relatively constant decline of

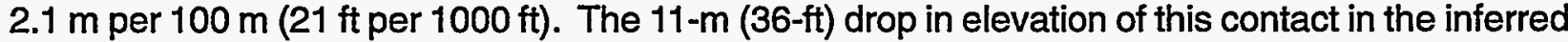
fault zone is greater than would be expected $(7 \mathrm{~m}$ or $23 \mathrm{ft})$ if there were no faulting. The difference between actual and expected contact elevations, $4 \mathrm{~m}(13 \mathrm{ft})$, might be attributed to normal faulting with down-to-the-east offset. We estimate our uncertainty in mapping of the unit 2/nonwelded contact as approximately $0.6 \mathrm{~m}(2 \mathrm{ft})$ at each of the three inferred fault locations in this zone, leading to additive uncertainties in the inferred cumulative fault offset of $4 \pm 1.8 \mathrm{~m}$ (13 $\pm 6 \mathrm{ft}$ ).

Previous work by Vaniman and Wohletz (1990) from Pajarito Mesa north to the Los Alamos townsite projected the trace of the Rendija Canyon fault to cross Pajarito Mesa approximately at the western end of this inferred fault zone. If the inferred fault zone is related to the Rendija Canyon fault, then the broad zone of faulting is consistent with the breadth of similar dispersed fault zones that they mapped to the north of Pajarito Mesa. However, offsets along the Rendija Canyon fault north of the Los Alamos townsite are down to the west - an opposite sense of displacement compared to that inferred in Threemile Canyon. The opposed sense of apparent offset in Threemile Canyon contradicts the inferred extension of down-to-the-west faulting across this canyon.

If the inferred offsets in Threemile Canyon are part of a separate fault structure, then there is no need to link the sense of displacement with that on the Rendija Canyon fault. However, if there is only one fault structure along this trend, then the change in sense of displacement may indicate a scissor fault. Since pivotal movement around a singular rotation point is generally discounted in scissor offsets, a more likely explanation would be based on a strike-slip component of movement, with offset of broad anticlinal, synclinal, or dipping structure within the Bandelier Tuff. The contact between Tshirege Member unit 2 and the overlying nonwelded tuff drops in elevation about $3.1 \mathrm{~m}$ per $100 \mathrm{~m}$ ( $31 \mathrm{ft}$ per $1000 \mathrm{ft}$ ), from north to south (based on Vaniman and Wohletz, 1990). With this southward dip in the contact, a component of left-lateral displacement and/or displacement down to the east along the Rendija Canyon Fault could be one component of the displacements inferred in Threemile Canyon. It should be noted, however, that the mesa tops show no evidence of lateral offset. Over $120 \mathrm{~m}$ (400 ft) of left-lateral movement would be required if all of the inferred offset was caused by lateral movement. This amount of strike-slip offset is clearly unreasonable. The limited scale of mesa-edge embayments ( $30 \mathrm{~m}$ or $100 \mathrm{ft})$ constrains the maximum left-lateral component of any fault offsets to roughly $25 \%$. Thus there is no compelling evidence in support of lateral displacement.

This kinematic constraint, the inference of down-to-the-east rather than down-to-the-west offset, can be circumvented if the inferred faults are not extensions of the primary Rendija Canyon fault. The inferred fault offsets in the bottom of Threemile Canyon may still be related to the primary movement if these offsets are secondary (Coppersmith and Youngs, 1992), dispersed away from the primary fault. Secondary faults have rupture intervals smaller than that of the primary fault; secondary rupture planes at a high angle to the primary fault can have a different sense of offset. Vaniman and Wohletz (1990) mapped a secondary splay from the Rendija Canyon fault in the vicinity of Los Alamos Canyon, trending NE-SW rather than N-S. The offsets inferred in 
the bottom of Threemile Canyon, south of Pajarito Mesa, could be caused by comparable secondary fault splays that curve to the SW. This interpretation can be reconciled with the steepened eastward slope of the surge at the base of unit 4 on the mesa top, NE of the down-to-the-east fault zone inferred here for the canyon bottom (see text by Reneau et al., this report). If this relationship is borne out, the strikes of the inferred canyon-bottom faults shown in Plate 1 may be more easterly than depicted.

As an altemative to either primary or secondary fault offsets in explanation of the irregularities in the unit 2/nonwelded tuff contact, it is possible that no fault offset occur in Threemile Canyon if these irregularities simply reflect undulatory relief in the surface of moderately-welded tuff unit 2. Such stratigraphic irregularities may be caused by irregular topography or irregular scouring between eruptive pulses in the Bandelier Tuff.

Without further information, and particularly without trenching in the bottom of Threemile Canyon, it is not prudent to attribute the repetition of contacts in the bottom of Threemile Canyon either to faulting or to unfaulted stratigraphic undulations. For the purposes of MWDF siting, the distinction between these two causes is not of regulatory concern because no Holocene fault offsets of any orientation were found in trenches along the mesa top.

\section{Fault Offsets Observed in Mesa-Top Trenches: Relation to Previous Studies}

Trench data collected on mesa tops to the north of Pajarito Mesa (TA-63; Kolbe et al., 1995) show no evidence of distinct fault breaks in the soil profiles above the tuff, where Vaniman and Wohletz (1990) projected the Guaje Mountain fault across Mesita del Buey. Trenching at Pajarito Mesa has shown that, as at Mesita del Buey, no young offsets along this projection are found on Pajarito Mesa (Kolbe et al., 1994).

The trace of the Rendija Canyon fault was also projected across Pajarito Mesa by Vaniman and Wohletz (1990). This projection crosses the mesa approximately where trenches TW5 and TW6 were subsequently excavated (see Plate 1). Preliminary results from trench-wall mapping indicate at least seven pre-Holocene faults in the eastern part of trench TW5, with offset down to the west. The age of this faulting is constrained by the unfaulted overlying soil horizons that lie beneath the pre-Holocene (50-60 ka) El Cajete pumice (Kolbe et al., 1994; Reneau et al., this report). Although the location of these fault offsets is close to the Rendija Canyon fault projection of Vaniman and Wohletz (1990), this does not necessarily indicate a "fix" on the location of the Rendija projection across Pajarito Mesa. The azimuths of these fault offsets are highly variable and they may represent the eastern portion of a broad zone of deformation, as suggested for both the Rendija Canyon and Guaje Mountain fault projections by Vaniman and Wohletz (1990) and suggested by sporadic fault offsets observed in outcrop to the west of the trenched zones on Pajarito Mesa (see section on Observable Fault Offsets in Outcrop, above). Regardless of the genesis and projections of the fault offsets observed in trench TW5 at Pajarito Mesa, the data obtained so far reveal no Holocene fault movement (Kolbe et al., 1994). This conclusion is of greatest importance for MWDF siting, for it indicates that the site will satisfy the provisions of 40 CFR 270, part 270.14, by directly indicating the absence of any Holocene fault movement.

\section{FRACTURE DISTRIBUTIONS, ORIENTATIONS, AND APERTURES}

Topographic maps with two-foot contour intervals were used to locate and measure 591 fractures along the generally well-exposed south margin of Pajarito Mesa. The north margin of the mesa was not mapped because of the poor exposure on north-facing slopes. Mapping concentrated on fractures that could be traced from the cliff-forming exposures of unit 3 into the underlying 
nonwelded tuff; these are referred to as "mesa-penetrating" fractures in this report. The strike and dip of each mesa-penetrating fracture was measured with a Brunton compass and the aperture of each fracture was measured. The mesa-penetrating fractures were numbered and marked in the field. Fracture numbering is centered around fracture "F0" (fracture zero), near the western end of PS-1. From this position, fractures are numbered in increasing order $(F+n)$ to the east and in decreasing order (F-n) to the west. Notes were collected on special characteristics of particular fractures (see following section on fracture morphology and petrology). The range of fracture mapping extends from the longitude of NMSP line $482350 \mathrm{E}$ in the west to the eastern extent of PS-3, NMSP line $491100 \mathrm{E}$, at the east margin of Pajarito Mesa. This is a distance of $8750 \mathrm{ft}(2.7$ $\mathrm{km})$. The fracture maps are compiled in Plates 1 to 3.

\section{Fracture Distributions}

The abundance of mesa-penetrating fractures ranges from about 75 per $305 \mathrm{~m}$ (1000 ft) along the tuff unit 3 cliff at PS-1, to about 50 per $305 \mathrm{~m}(1000 \mathrm{ft})$ at PS-2, to about 40 per $305 \mathrm{~m}$ $(1000 \mathrm{ft})$ at PS-3. The decrease in abundance of mesa-penetrating fractures from west to east may be related to the decrease in the degree of welding of tuff unit 3 from west to east. This apparent correlation between degree of welding in the mesa cap and fracture penetration suggests that fractures formed within a more indurated tuff unit have greater potential for propagating downward into underlying nonwelded units. Proximity to deep fault zones may also be a factor, but this is not evident in the data on mesa-penetrating fractures collected for Pajarito Mesa.

A potential problem in the interpretation of fracture distributions is the impact of missing fracture data. This is a minor problem for the cliff along PS-1, but there are several cliff segments at PS-2 and PS-3 where fracture exposures are covered by bouldery colluvium. These parts of the mesa can accumulate bouldery colluvium whereas PS-1 does not, because the cliff slopes at PS2 and PS-3 are gentler, unlike the vertical cliff at PS-1. Also, there are more deeply-incised embayments, particularly at PS-2, where blocks of tuff may accumulate. These covered zones were not used in making the estimates of fracture spacings cited above, which are based only on well-exposed cliff zones. However, the covered intervals at PS-2 and PS-3 could conceal some zones of more intense fracturing. More trenching on the mesa top, in PS-2 and PS-3, would be required for a more continuous fracture record.

\section{Fracture Orientations}

Figures 2 to 7 are rose diagrams and histograms that illustrate the distributions of fracture strike orientations at Pajarito Mesa. Rose diagrams are shown for mesa-penetrating fractures along the southern mesa margin at PS- 1 , along the small "finger mesa" between PS-1 and PS-2 (see Fig. 1), along the main mesa margin behind the finger mesa ("backfinger"), along the mesa margin at PS-2, and along the mesa margin at PS-3. Although some bias may be introduced into these measurements because of the orientation of the cliff exposures studied, the relatively consistent $E-W$ orientation of the cliff face should produce a consistent bias, allowing comparisons to be made within this data set.

A prominent NNE fracture orientation is evident at PS-1 and along the finger mesa (Figs. 2 and 3). The average fracture strike at $P S-1$ is $N 17^{\circ} \mathrm{E}$ with relatively high confidence $\left( \pm 15^{\circ}\right)$. This fracture orientation is subparallel to the mapped orientation of the Rendija Canyon Fault trace west of PS-1, and the prominence of this orientation at PS-1 may be related to this structure.

A comparison of the fracture orientations along the finger mesa (Fig. 3) with those behind this finger and along the main mesa (backfinger; Fig. 4) shows a strong dissimilarity, although the small number of measurable mesa-penetrating fractures in the backfinger leads to large 

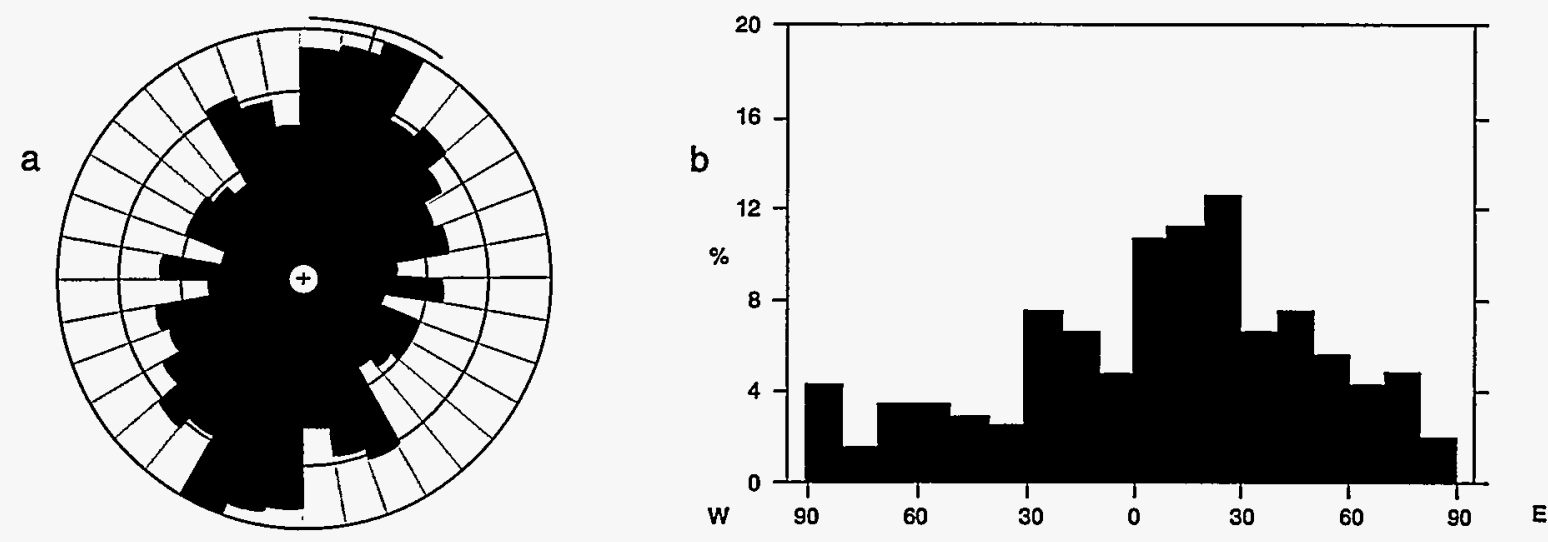

\begin{tabular}{|l|l|}
\hline $\mathrm{PS} 1$ & Statistics \\
\hline $\mathrm{N}=216$ & Vector Mean $=17.0$ \\
Class Interval $=10$ degrees & Conf. Angle $=15.36$ \\
Maximum Percentage $=12.5$ & \\
Mean Percentage $=5.56$ Standard Deviation $=3.20$ & \\
\hline
\end{tabular}

Fig. 2. (a) Equal-area rose diagram for 216 fracture orientations at PS-1 (see Figure 1). Note strong preferred fracture orientation of $\mathrm{N} 17^{\circ} \mathrm{E}$. (b) Histogram of fracture orientations.

uncertainties. The prominent NNE fracture orientation in Fig. 3 is most similar to the fracture set of PS-1, whereas there is no apparent preferred orientation in Figure 4.

The fractures along PS-2 (Fig. 5) have no single prominent orientation, but instead are oriented in at least two sets: a broad distribution from N-S to $\mathrm{N} 20^{\circ} \mathrm{E}$ and another cluster of approximately $\mathrm{E}-\mathrm{W}$ orientation. Other orientations are common, weakening the prominence of any preferred orientation.

At PS-3 (Fig. 6) the fracture orientations are broadly isotropic. The commonest fracture orientations are NE and NW, and there appears to be a significant paucity of fractures trending E$W$, but orientations are so broadly distributed that a larger data set would be needed to draw more detailed conclusions. Some of the scatter in fracture orientations at PS-3 may be attributed to the
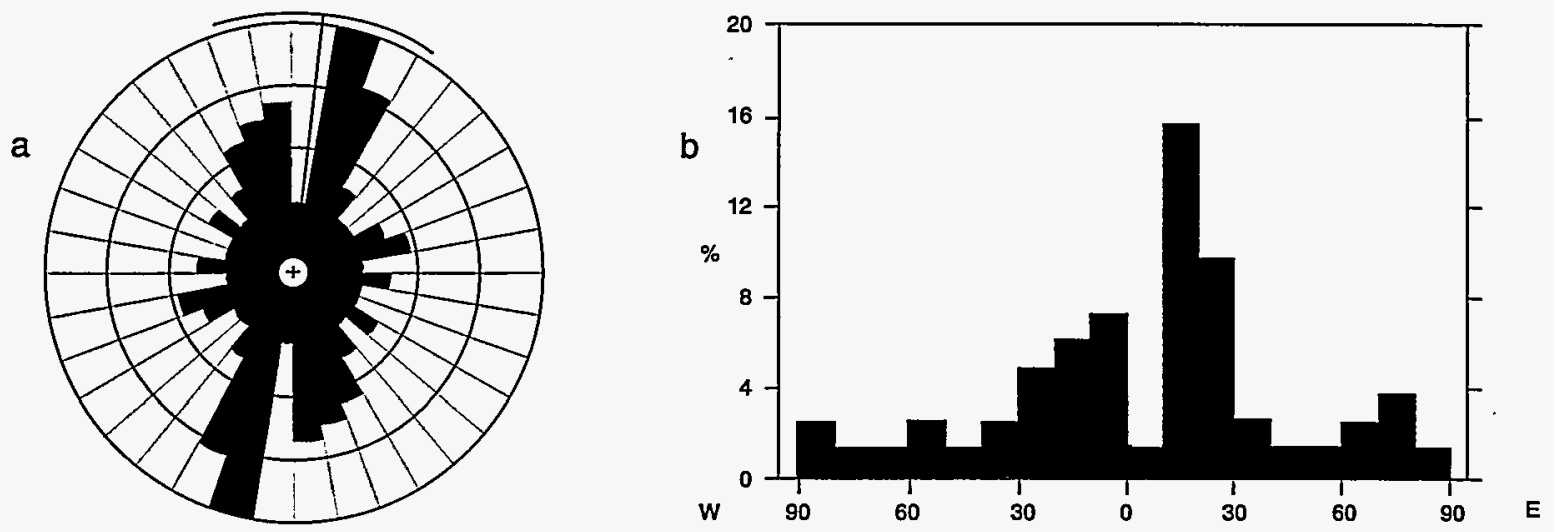

\begin{tabular}{|l|l|}
\hline Finger Mesa & \multicolumn{1}{|c|}{ Statistics } \\
\hline $\mathrm{N}=56$ & Vector Mean $=6.4$ \\
Class Interval $=\mathbf{1 0}$ degrees & Conf. Angle $=24.78$ \\
Maximum Percentage $=\mathbf{2 3 . 2}$ & \\
Mean Percentage $=\mathbf{5 . 5 6}$ Standard Deviation $=5.59$ & \\
\hline
\end{tabular}

Fig. 3. (a) Equal-area rose diagram for 56 fracture orientations along the finger mesa (see Figure 1). A prominent fracture set occurs at $\mathrm{N} 10^{\circ} \mathrm{E}$ to $\mathrm{N} 20^{\circ} \mathrm{E}$, comparable to PS-1 (Figure 2). (b) Histogram of fracture orientations. 

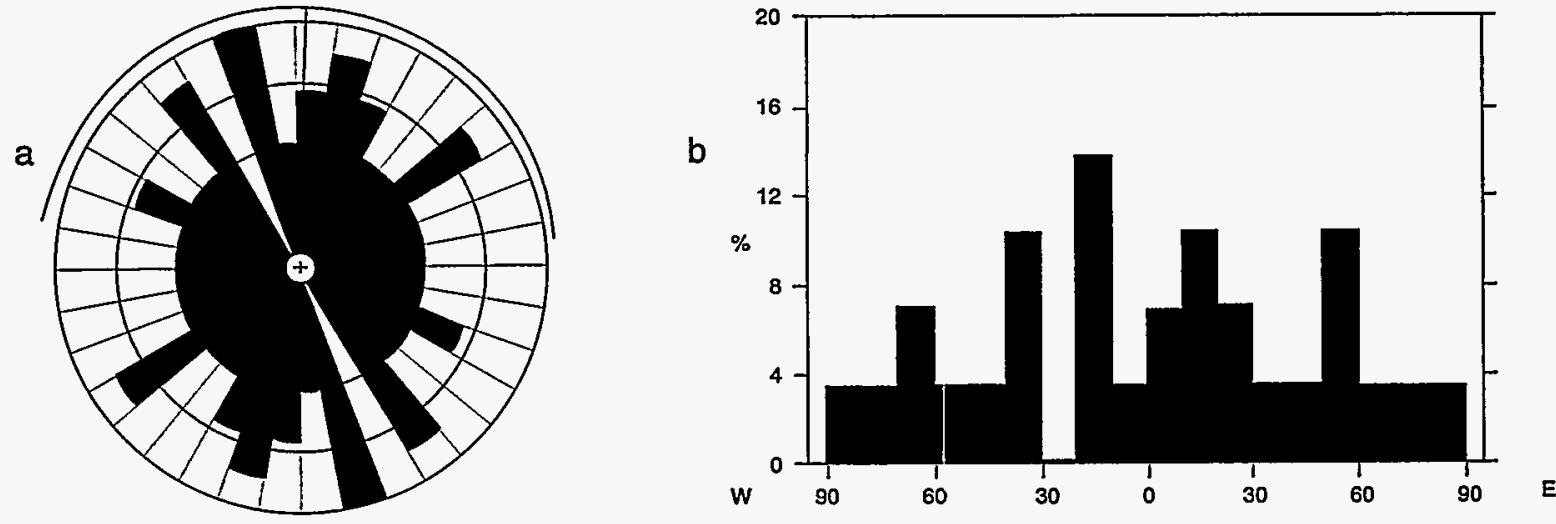

\begin{tabular}{|l|l|}
\hline Backfinger (main mesa behind finger mesa) & \multicolumn{1}{|c|}{ Statistics } \\
\hline $\mathrm{N}=29$ & Vector Mean $=2.2$ \\
Class Interval $=10$ degrees & Conf. Angle $=81.55$ \\
Maximum Percentage $=13.8$ & \\
Mean Percentage $=5.88$ Standard Deviation = 3.35 & \\
\hline
\end{tabular}

Fig. 4. (a) Equal-area rose diagram for 29 fracture orientations along the backfinger (see Fig. 1). There is no evidence of preferred fracture orientation; interpretations from these data are limited by the small number of measurable mesapenetrating fractures. (b) Histogram of fracture orientations.

a

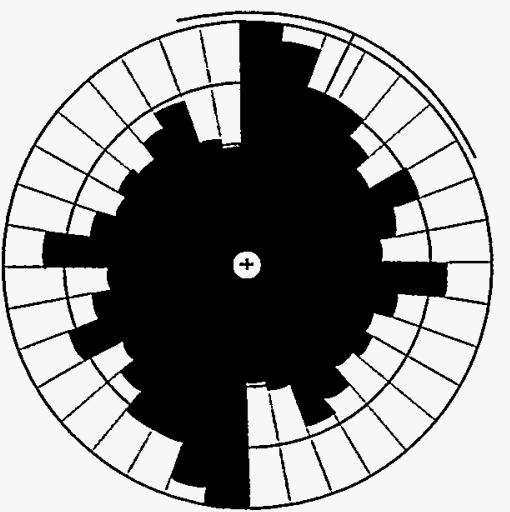

b

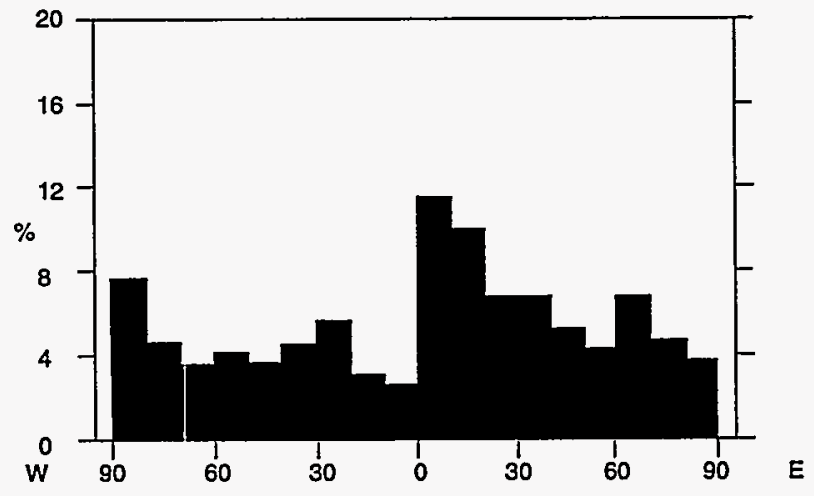

Fig. 5. (a) Equal-area rose diagram for 191 fracture orientations at PS-2 (see Fig. 1). Most prominent fractures are oriented $\mathrm{N}-\mathrm{S}$ to $\mathrm{N} 20^{\circ} \mathrm{E}$, but other orientations are common, weakening the prominence of this preferred orientation. (b) Histogram of fracture orientations.

collection of data from several cliff segments that trend more N-S than E-W, but this accounts for only about $40 \%$ of the data for PS-3. The effect of these N-S trending cliff segments can be assessed by considering only those fractures measured from $E-W$ trending cliffs (Fig. 7). This subset of 60 fractures shows that although $\mathrm{N}$-trending fractures are more prominent than they were in Fig. 6, the same general distribution of fracture orientations is observed. The rose diagrams of Figs. 6 and 7, taken together, indicate a widely scattered distribution of fracture orientations with weakly developed NE, NW, and N-S preferred orientations. 

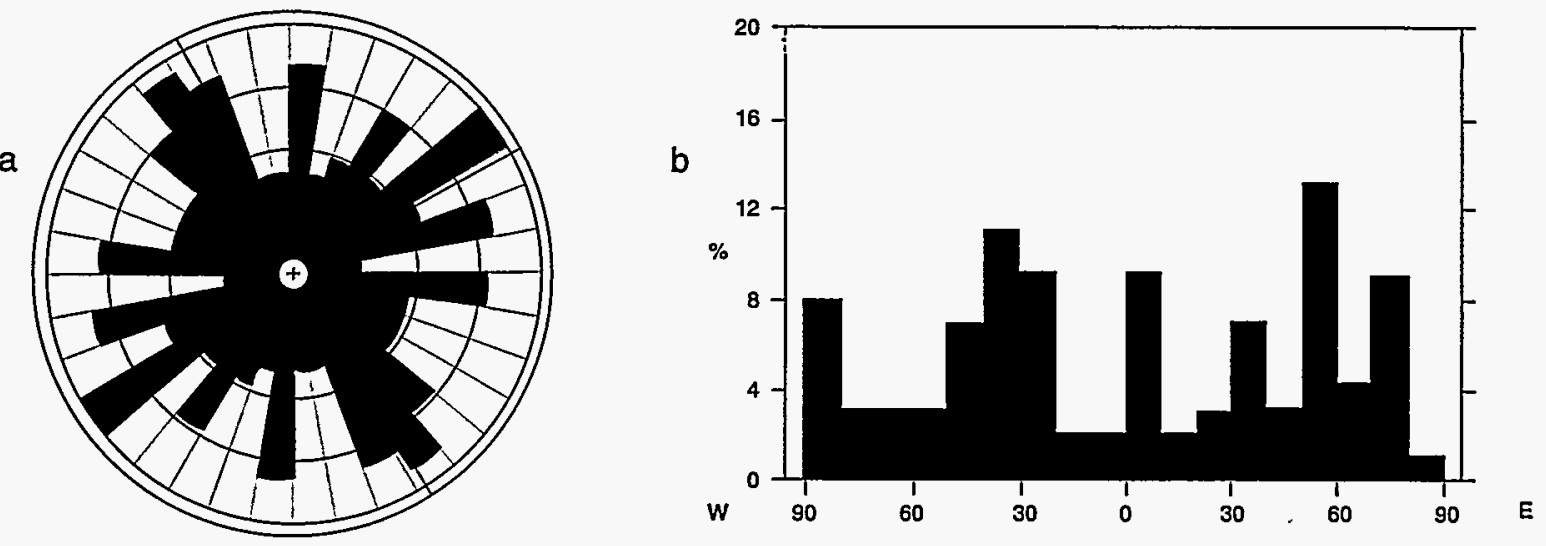

\begin{tabular}{||l|l|}
\hline PS3 & \multicolumn{1}{|c|}{ Statistics } \\
\hline $\mathrm{N}=99$ & Vector Mean $=61.8$ \\
Class Interval $=10$ degrees & Conf. Angle $=477.66$ \\
Maximum Percentage $=13.1$ & \\
Mean Percentage $=5.56$ Standard Devlation $=3.62$ & \\
\hline
\end{tabular}

Fig. 6. (a) Equal-area rose diagram for 99 fracture orientations at PS-3 (see Fig. 1). Note that the very broad scatter of fracture orientations leads to no confidence angle $\left(>360^{\circ}\right)$. Approximately $25 \%$ of the fractures measured for PS-3 occur on cliff faces of more N-S than E-W orientation; this may tend to reduce the number of N-S oriented fractures measured. Nevertheless, fractures of NW and NE orientation are more prominent than in other areas measured at Pajarito Mesa (see Fig. 7). (b) Histogram of fracture orientations.

a

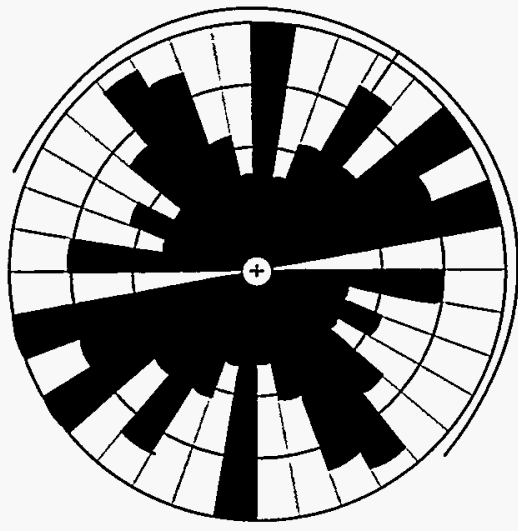

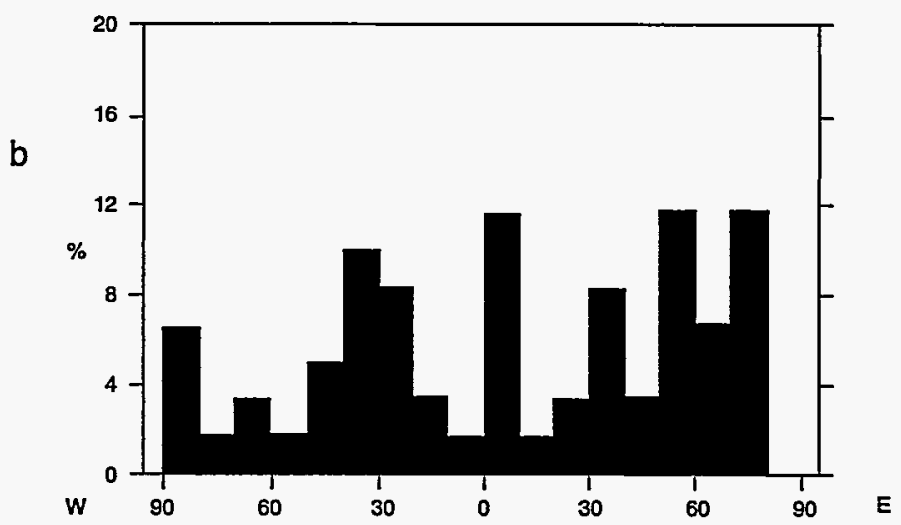

\begin{tabular}{||l|l|}
\hline PS3, E-W clitts & \multicolumn{1}{|c|}{ Statistics } \\
\hline $\mathrm{N}=60$ & Vector Mean $=33.7$ \\
Class Interval $=10$ degrees & Conf. Angle $=100.88$ \\
Maximum Percentage $=11.7$ & R Magnitude $=0.103$ \\
Mean Percentage $=5.88$ Standard Deviation $=3.72$ & Rayleigh $=0.5307$ \\
\hline
\end{tabular}

Fig. 7. Subset of 60 fractures measured from E-W trending cliffs at PS-3. (a) Equal-area rose diagram and (b) histogram of fracture orientations. Note that although the N-trending fractures are more prominent than they were in Fig. 6 , the same general distribution of fracture orientations is observed.

\section{Fracture Apertures}

Fractures exposed at the mesa margin within tuff unit 3 are seldom sealed. Fractures tend to be open, with undulatory walls. Where fractures penetrate into the nonwelded tuffs underlying unit 3, they are not open but are instead filled with tuff detritus and clay; in some instances, fractures terminate in the nonwelded tuff and the clay from the fractures spreads laterally into small-scale sill-like features (see section below on Petrologic/mineralogic evidence for possible barriers to 
transport, and Fig. 9). Because of the variability in fracture aperture, depending on where a measurement is taken, the measurements recorded were of average aperture to the nearest centimeter (e.g., $0,1,2,3 \mathrm{~cm}$, etc.). Typical fracture apertures are closest to $1 \mathrm{~cm}$. Histograms of fracture aperture are shown for the mesa margins at PS-1, PS-2, and PS-3 in Figure 8.

Locality PS-1 has the largest number of fractures with more than $10 \mathrm{~cm}$ aperture. The prominent fracture trend at $\mathrm{PS}-1$ is $\mathrm{N} 17^{\circ} \mathrm{E} \pm 15^{\circ}$ (Fig. 2), but most of the NE-trending wide-aperture

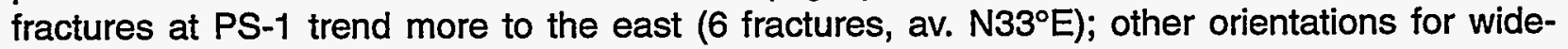
aperture fractures are NW ( 3 fractures, av. N31 $\mathrm{W}$ ) or $\mathrm{E}-\mathrm{W}$ (one fracture).

Table 1 summarizes the fracture-aperture statistics for the cliff margins at PS-1, PS-2, and PS-3. The mean fracture aperture is greatest in PS-1 and least in PS-2; standard deviations are comparable in magnitude to the means, indicating that the differences in average fracture width for the three areas are not statistically significant. However, there is a consistently higher percentage of large fractures at PS-1, compared to PS-2 and PS-3. This feature of PS-1 can be readily seen in Figure 8.
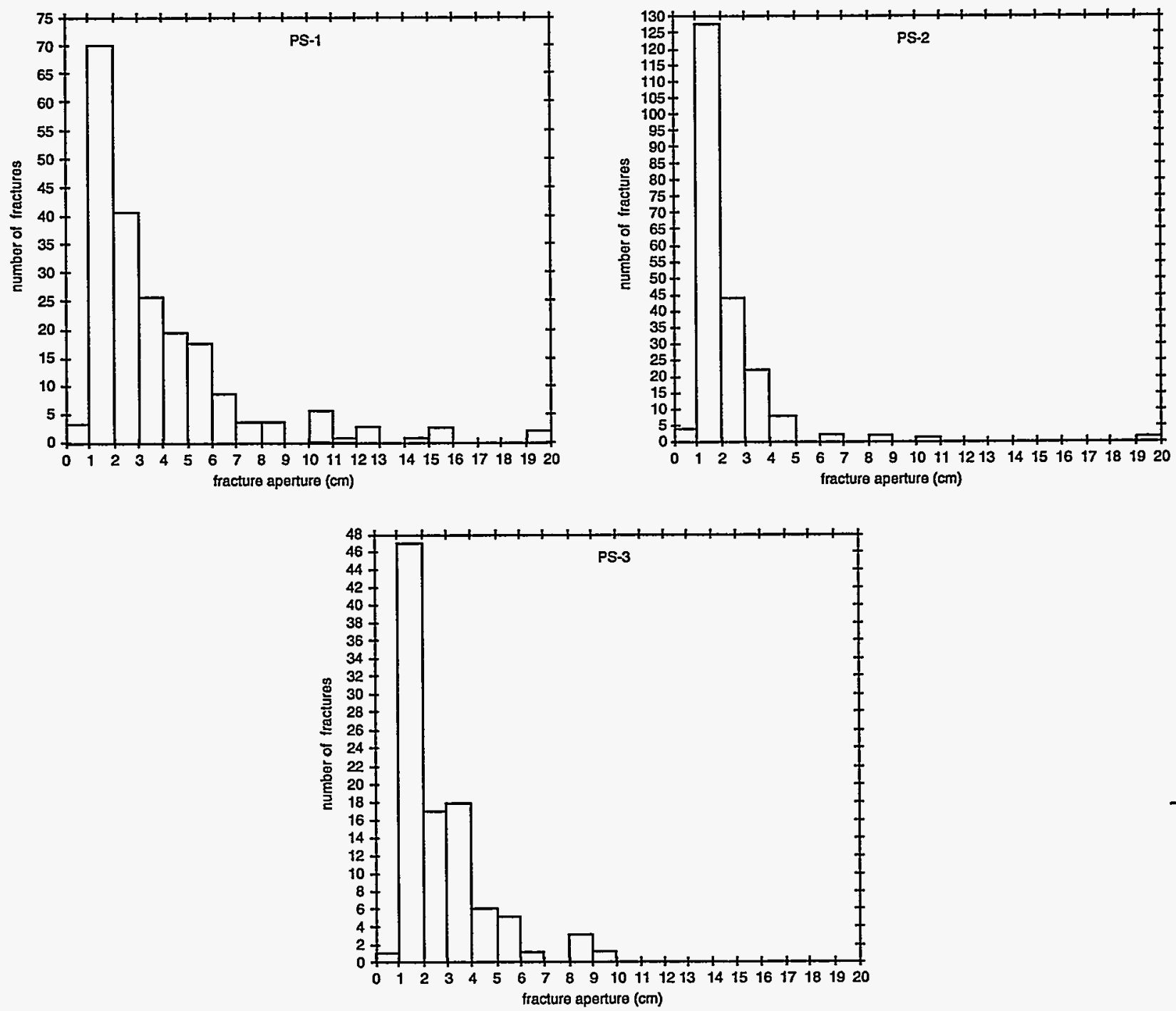

Fig. 8. Histograms of fracture apertures for PS-1, PS-2, and PS-3. Exceptionally wide fractures are more common at PS- 1 than at PS-2 or PS-3. 


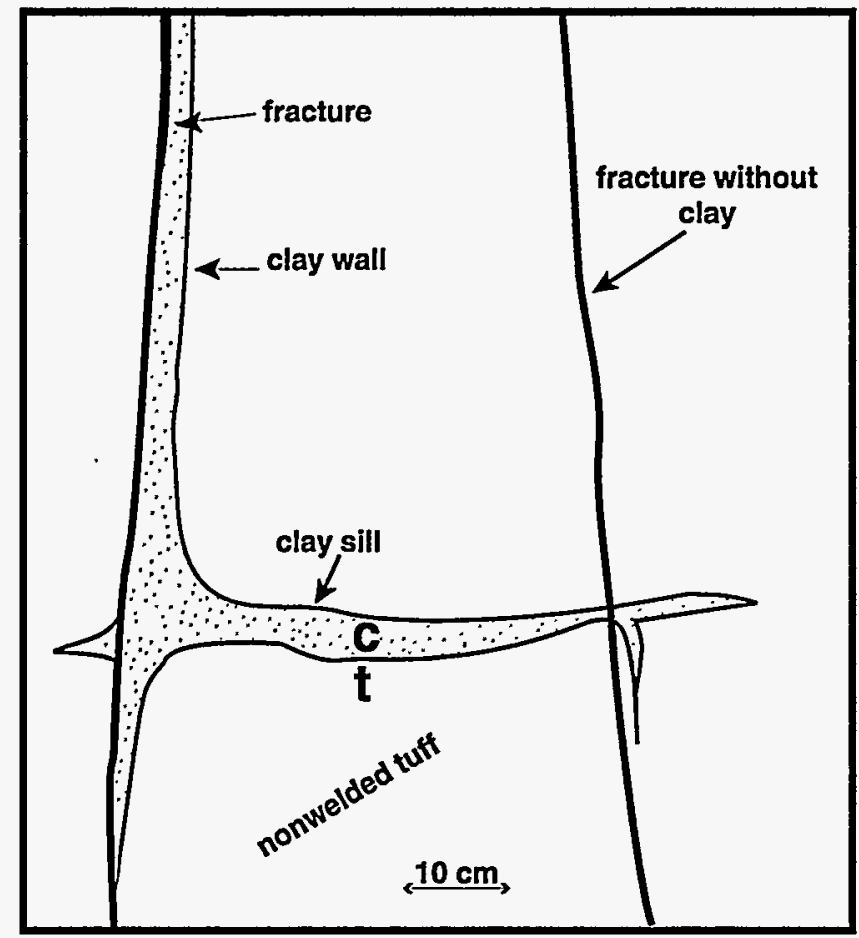

Fig. 9. Sketch showing dispersal of clay from mesa-penetrating fractures into horizontal substrata of nonwelded tuff, fracture $F+192$. Locations of clay-sill sample (c) and of unaltered tuff sample $(t)$ are indicated, for comparison with the data for $F+192$ in Table 3.

\section{FRACTURE MINERALOGY AND PETROGRAPHY}

Mineral deposits within fractures are common at Pajarito Mesa, particularly in fractures exposed in trenches excavated in the mesa top and at the interface between welded and nonwelded tuffs at the break-in-slope at the bottom of the mesa-bounding unit 3 cliff. Table 2 summarizes the mineralogic data for 9 samples collected from trenches at the surface of Pajarito Mesa in areas PS-1 and PS-2; these trenches are shown in Plates 1 and 2 (trenches TW5, TW2, TE2, TE4, TE5, TE6, and TE8). Table 3 lists comparable data for samples from 17 fractures collected from the bottom of the mesa-bounding cliff along the southern margins of PS-1 and PS-2. The fracture-sample locations of Table 3 are also shown on Plates 1 and 2. Mineral abundances were determined by quantitative $X$-ray diffraction (QXRD). Sample preparation and analysis procedures are described in Broxton et al. (this report).

The commonest mineral filling in these fractures is smectite clay (up to $86 \%$ ); this mineral is ubiquitous wherever mineral fillings occur in fractures. Lesser amounts of kaolinite and calcite occur with the smectite. Gypsum and halite are also found, notably in fracture samples at the bottom of the mesa-bounding cliff, providing evidence of evaporative processes that deserve particular mention. The smectite common to all fractures is more abundant in the shallow trenchexposed fractures (Table 2) than in the deeper fractures exposed in the cliff margins (Table 3 ). This reflects the more abundant illuviation of clay closer to the surface, with greater dilution of those minerals that represent tuff detritus (principally tridymite, cristobalite, quartz, and feldspar). The silica polymorphs in particular appear to reflect the composition of local tuffs. For instance, those near-surface fractures from trenches within unit 4 (all of the "TW" trenches in Table 2) have no detectable tridymite, in accord with the very low tridymite abundances in this unit (see Broxton et al., this report). In addition, the fractures at the mesa bottom in unit 3 have no detectable cristobalite, as observed in the immediately adjacent tuff, even though tuff samples from a few feet higher do contain cristobalite (Broxton et al., this report). The distributions of detrital minerals, especially of

TABLE 1. Fracture-Apertures for Cliff Margins

\begin{tabular}{lccc}
\hline & PS-1 & PS-2 & PS-3 \\
\hline Number of fractures $(\mathrm{n})$ & 216 & 191 & 99 \\
Mean aperture $(\mathrm{cm})$ & 3.4 & 1.9 & 2.3 \\
Std. deviation $(\mathrm{cm})$ & 3.4 & 2.2 & 1.8 \\
$\%$ fractures $>2 \mathrm{~cm}$ & $44 \%$ & $18 \%$ & $34 \%$ \\
$\%$ fractures $>5 \mathrm{~cm}$ & $15 \%$ & $2 \%$ & $5 \%$ \\
$\%$ fractures $>10 \mathrm{~cm}$ & $5 \%$ & $1 \%$ & 0
\end{tabular}


TABLE 2. Fracture Mineralogy, Trenches at Mesa Top, Pajarito Mesa, areas PS-1 and PS-2

\begin{tabular}{lllllllllllr}
\hline \multicolumn{1}{c}{ Sample } & Type & Smect & Kaol & Trid & Crist & Quartz & Feld & Hem & Calcite & Halite & Total \\
\hline Trench TW5\#3 & clay & $44(13)$ & $1(1)$ & - & $10(1)$ & $7(1)$ & $36(5)$ & $1(1)$ & - & - & $99(14)$ \\
Trench TW5\#2 & clay & $60(18)$ & $2(1)$ & - & $4(1)$ & $6(1)$ & $18(3)$ & - & $1(1)$ & - & $91(18)$ \\
Trench TW5\#1 & clay & $86(26)$ & $3(1)$ & - & $1(1)$ & $2(1)$ & $8(1)$ & - & $1(1)$ & $\operatorname{tr} ?$ & $101(26)$ \\
Trench TW2 & clay & $62(19)$ & $2(1)$ & - & $2(1)$ & $4(1)$ & $21(3)$ & $1(1)$ & $4(1)$ & - & $96(19)$ \\
Trench TE2 & clay & $25(8)$ & $1(1)$ & $9(1)$ & $2(1)$ & $13(1)$ & $46(6)$ & - & $1(1)$ & $\operatorname{tr}$ & $97(10)$ \\
Trench TE4 & clay & $36(11)$ & $1(1)$ & $9(1)$ & $2(1)$ & $11(1)$ & $36(5)$ & $\operatorname{tr}$ & $2(1)$ & $\operatorname{tr}$ & $97(12)$ \\
Trench TE5 & clay & $42(13)$ & $1(1)$ & $7(1)$ & $2(1)$ & $10(1)$ & $32(4)$ & $\operatorname{tr}$ & $\overline{t r}$ & $\operatorname{tr}$ & $94(14)$ \\
Trench TE6 & clay & $56(17)$ & $2(1)$ & $4(1)$ & $2(1)$ & $7(1)$ & $24(3)$ & $\operatorname{tr}$ & $1(1)$ & - & $96(17)$ \\
Trench TE8 & clay & $38(11)$ & $1(1)$ & $4(1)$ & $4(1)$ & $18(1)$ & $36(5)$ & $1(1)$ & - & - & $102(12)$ \\
\hline
\end{tabular}

Notes: Quantitative X-ray diffraction data. Abundances listed in weight percent, with one standard deviation in parantheses.

Detection of minor and trace amounts, $<1 \%$, indicated by "tr"; minerals not detected indicated by "- ". Mineral abbreviations are smectite (smect), kaolinite (kaol), tridymite (trid), cristobalite (crist), feldspar (feld), and hematite (hem).

TABLE 3. Fracture Mineralogy, South Cliff, Pajarito Mesa, areas PS-1 and PS-2

\begin{tabular}{|c|c|c|c|c|c|c|c|c|c|c|c|c|c|}
\hline Sample & Type & Smect & Kaol & Trid & Quartz & Feld & $\mathrm{Hem}$ & Calcite & Biotite & Amph & Gyps & Halite & Total \\
\hline$F-94$ & clay & $17(5)$ & - & $9(1)$ & $23(2)$ & $51(7)$ & $\operatorname{tr}$ & - & - & $\overline{-}$ & $\overline{-}$ & $\overline{-}$ & $100(9)$ \\
\hline F-73 & clay & $36(11)$ & $1(1)$ & $10(1)$ & $10(1)$ & $40(6)$ & $\operatorname{tr}$ & - & - & - & - & 一 & $97(13)$ \\
\hline$F-59$ & clay & $27(8)$ & $\operatorname{tr}$ & $7(1)$ & $12(1)$ & $54(8)$ & - & - & 一 & - & - & 一 & $100(11)$ \\
\hline$F-42$ & clay & $61(18)$ & $3(1)$ & 2(1) & $9(1)$ & $20(3)$ & - & - & - & 一 & - & - & $95(18)$ \\
\hline$F-25$ & clay & $58(17)$ & $3(1)$ & 2(1) & $7(1)$ & $22(3)$ & - & - & - & - & - & - & $92(17)$ \\
\hline$F+31$ & clay & $53(16)$ & $3(1)$ & $5(1)$ & $8(1)$ & $28(4)$ & - & tr & - & - & - & - & $97(17)$ \\
\hline$F+93$ & clay & $32(10)$ & $2(1)$ & $8(1)$ & $15(1)$ & $38(5)$ & - & - & - & - & - & - & $95(11)$ \\
\hline$F+125$ & clay & $4(1)$ & -1 & $15(1)$ & $22(2)$ & $61(9)$ & - & $2(1)$ & 一 & - & 一 & - & $104(9)$ \\
\hline$F+132$ & clay & $42(13)$ & $\operatorname{tr}$ & $7(1)$ & $11(1)$ & $38(5)$ & - & - & - & - & - & - & $98(14)$ \\
\hline$F+144$ & tuff & $1(1)$ & - & $12(1)$ & $17(1)$ & $71(10)$ & $\operatorname{tr}$ & - & - & - & - & - & $101(10)$ \\
\hline$F+144$ & fracture wall & 1(1) & - & $10(1)$ & $15(1)$ & $68(10)$ & $7(1)$ & - & - & 一 & - & 一 & $101(10)$ \\
\hline$F+192$ & tuff & $1(1)$ & - & $23(2)$ & $17(1$ & $61(9)$ & - & - & - & - & - & 一 & $102(9)$ \\
\hline$F+192$ & clay sill & $9(3)$ & - & $25(2)$ & $14(1)$ & $52(7)$ & - & - & - & - & - & - & $100(8)$ \\
\hline$F+193$ & clay & $72(22)$ & $4(1)$ & $2(1)$ & $3(1)$ & $14(2)$ & - & - & - & - & - & - & $95(22)$ \\
\hline$F+203$ & tuff & - & - & $18(1)$ & $23(2)$ & $60(8)$ & - & - & $\operatorname{tr}$ & $\operatorname{tr}$ & - & - & $101(8)$ \\
\hline$F+203$ & clay sill & $8(2)$ & - & $13(1)$ & $20(2)$ & $58(8)$ & - & - & - & - & - & - & $99(9)$ \\
\hline $\mathrm{F}+203$ & fracture clay & $11(3)$ & - & $16(1)$ & $20(2)$ & $61(9)$ & - & - & - & 一 & 一 & - & $108(10)$ \\
\hline$F+207$ & clay & $68(20)$ & $2(1)$ & $4(1)$ & $5(1)$ & $25(4)$ & 一 & 一 & - & 一 & - & - & $104(20)$ \\
\hline$F+220$ & clay & $8(2)$ & - & $5(1)$ & $21(2)$ & $60(8)$ & - & - & 一 & - & $1(1)$ & $10(1)$ & $105(9)$ \\
\hline$F+228$ & tuff & - & - & $16(1)$ & $21(2)$ & $61(9)$ & - & - & - & 一 & - & - & $98(9)$ \\
\hline $\mathrm{F}+228$ & clay sill & $8(2)$ & - & $17(1)$ & $16(1)$ & $56(8)$ & - & - & - & - & $\operatorname{tr}$ & - & $97(8)$ \\
\hline$F+229$ & clay & $8(2)$ & - & $15(1)$ & $14(1)$ & $54(8)$ & tr & $1(1)$ & - & $\operatorname{tr}$ & $1(1)$ & $10(1)$ & $103(9)$ \\
\hline
\end{tabular}

Notes: Quantitative X-ray diffraction data. Abundances listed in weight percent, with one standard deviation in parentheses.

Detection of minor and trace amounts, $<1 \%$, indicated by " $4 r$ "; minerals not detected indicated by " - ". Mineral abbreviations are smectite (smect), kaolinite (kaol), tridymite (trid), feldspar (feld), hematite (hem), amphibole (amph), and gypsum (gyps). 
cristobalite, suggest little movement of tuff fragments within fractures despite the evidence for clay illuviation.

\section{Early Hematite Alteration Along Some Fracture Walls}

One fracture at the bottom of the mesa-bounding cliff $(F+144)$ did not have a mineral filling but did have strongly reddened fracture walls; the mineralogic analysis of these reddened fracture walls is compared to the nonreddened, unaltered tuff in Table 3. The reddening is due to the development of dispersed hematite along the fracture wall, a type of alteration that appears to be part of the vapor-phase or fumarolic alteration that occurred soon after tuff emplacement. Hematite alteration of this nature is not representative of the current transport and alteration regime at Pajarito Mesa, whereas smectite formation and transport is.

\section{Smectite Formation and Transport}

Smectite is particularly abundant and common in the fractures along the mesa margin at PS-1. It appears to occur in more variable abundances in the fractures at PS-2, both on top of the mesa (samples from trenches TE-2 to TE-8, smectite abundances as low as 25\%, Table 2) and at the bottom of the mesa-bounding cliff (samples from fractures of PS-2 commonly have smectite abundances of only $8-11 \%$, Table 3 ). X-ray diffraction analysis of clay separates from both the trenches at the mesa top and the mesa-penetrating fractures show them to be strongly similar, suggesting that smectites form in the soil zone and are translocated into the fractures in the underlying tuff. Other studies have reached similar conclusions for trench samples (Davenport, 1993) based on illuviation structures in the shallow fracture-filling clays. Comparable illuviation features (e.g., cuspate-downward laminations) have been found in fractures at the base of the cliff, up to $15 \mathrm{~m}(50 \mathrm{ft})$ below the mesa top. Mineralogic similarities thus suggest that clay transport has occurred over ranges as great as $15 \mathrm{~m}(50 \mathrm{~m})$, and perhaps farther, downward into Pajarito Mesa. The variation in clay illuviation depths suggests less particulate transport into deep fractures $>10$ $\mathrm{m}$ or $33 \mathrm{ft}$ ) in the eastern part of the Pajarito Plateau than in the western part. This difference in clay illuviation may reflect differences in effective soil saturation at the mesa top, where the eastern mesa is characterized by an abundance of piñon-juniper-cactus vegetation and the western mesa supports abundant ponderosa pine. Alternatively, the decrease in fracture apertures in the eastern part of Pajarito Mesa (Fig. 8) may restrict transport by illuviation.

\section{Petrologic/Mineralogic Evidence for Possible Barriers to Transport}

Because the fractures mapped for this report are specifically those that are mesa-penetrating, it is possible to examine the presence or absence of any evidence for transport through the nonwelded interval at the base of the mesa. Figure 9 illustrates a feature commonly observed in the southern cliff margin of PS-2. Here the clay illuviation downward into mesa fractures penetrates a short distance into the nonwelded tuff before it is no longer able pass along the tightly sealed fracture trace. Clay penetration is then diverted away from the fracture and into thin substrata or lenses within the nonwelded unit. The clay-rich layers are seldom more than a few centimeters thick; the layers can not be traced laterally unless discolored by clay infiltration. This phenomenon indicates that there are sub-decimeter-scale substrata or lenses of greater permeability within the less permeable parts of the nonwelded tuffs. Because of the lack of any visible pre-alteration stratification in the adjacent nonwelded tuffs, it is possible that small differences in permeability caused by variable compaction may be the principal factor in determining whether or not the clays will infiltrate laterally into the tuff. This potential for small-scale permeability variations should be 
considered in hydrologic models of contaminant transport downward from existing or potential waste sites on mesa tops.

\section{Flow to the Mesa Edge: Discharge or Evaporation?}

One of the surprises encountered in the analysis of fracture-filling materials from Pajarito Mesa was the occurrence of evaporite minerals (gypsum and halite) from deep fracture fillings near PS-2. Two fractures 226 to $271 \mathrm{~m}$ (740 to $890 \mathrm{ft}$ ) to the east of the potential MWDF boundary $(F+220$ and $F+229$, Table 3$)$ contain about $10 \%$ halite and $1 \%$ gypsum. Trace amounts of halite occur in clays at the mesa surface (Table 2), but not in the high concentrations seen in the clay deposits at the mesa bottom. The concentration of smectite at PS-2 strongly suggests that certain fractures will transport fluids during wetting cycles but, rather than discharging these fluids at the mesa edge, the clays in the fractures retain the fluids and concentrate the salts in solution as the water later evaporates on exposure at the mesa margin. However, the data available support this concept only at PS-2 and not at PS-1, where halite was not found with the smectites that occur in fractures at the mesa margin.

\section{CONCLUSIONS}

Direct evidence for fault-related structures at Pajarito Mesa is found immediately to the west of the potential MWDF boundary, in fault offsets observed in trench TW5. Offsets in outcrop are found farther to the west, about $490 \mathrm{~m}$ (1600 ft) from the potential MWDF boundary. These fault offsets, down to the west in TW5 but more variable in outcrop, may be related to the southern extent of the Rendija Canyon fault as mapped by Vaniman and Wohletz (1990). Inferred fault offsets in the bottom of Threemile Canyon have an opposite sense of apparent offset: down to the east. These inferred fault offsets in the canyon bottom may instead represent irregular flow-unit topography within the tuff, unrelated to faulting. We consider it more likely that the inferred fault offsets may be related to a zone of relatively steep eastward dip in the surge horizon at the base of tuff unit 4 on the mesa top, NE of the inferred faults in Threemile Canyon (Reneau et al., this report). Regardless of these various interpretations, the absence of any evidence for Holocene offset in faults at the mesa top (Kolbe et al., 1994) indicates that the MWDF site is not compromised by young faulting.

Mesa-penetrating fractures (i.e., those fractures that pass from the cliff-forming tuff unit 3 into underlying nonwelded tuff) were mapped along the southern edge of Pajarito Mesa. These fractures show no concentration of abundance or increase in aperture associated with the previously inferred projections of the Rendija Canyon or Guaje Mountain faults (Vaniman and Wohletz, 1990). Instead, average fracture apertures increase to the west (from $\sim 2 \mathrm{~cm}$ to $\sim 3 \mathrm{~cm}$ ), the proportion of fractures with apertures $>5 \mathrm{~cm}$ increases to the west from $3-5 \%$ to $20 \%$, and fracture orientations in the west are strongly oriented at $\mathrm{N} 17^{\circ} \mathrm{E} \pm 15^{\circ}$. This western zone of relatively wide and oriented fractures represents the potential MWDF locality.

Abundant clay minerals are formed in soils at the mesa top and transported downward into deeper fractures. In general, clay transport is effectively stopped where these fractures pass into the nonwelded tuff at the mesa base, where clay transport can be diverted over short distances into the more permeable layers of nonwelded tuff rather than moving farther downward. The mineralogic data suggest that fracture transport just above the nonwelded tuff can discharge fluids at the mesa base, but evaporative salts (especially halite) indicate that evaporative concentration may prevent many solutes from escaping from the mesa. However, the evidence for this evaporation effect is found only in those parts of the mesa to the east of the potential MWDF facility boundary where surface vegetation (piñon-juniper-cactus vs. ponderosa pine) indicates less soil saturation. 


\section{ACKNOWLEDGMENTS}

This work was funded by the Los Alamos National Laboratory Environmental Restoration Project as part of site characterization activities for the proposed Mixed Waste Disposal Facility. The authors thank Paul Aamodt, Darrell Bultman, Bob Gillis, Steven Reneau, David Broxton, Chuck Harrington, and Dean Nelson for their support; Doug Walther with FIMAD for map preparation; and Steven Reneau and John Wolff for reviews that helped to improve the manuscript.

\section{REFERENCES}

Broxton, D. E., Vaniman, D., Byers, F. M., Jr., Chipera, S. J., Kluk, E. C., and Warren, R. G., 1995, Stratigraphy, mineralogy and chemistry of befrock tuffs at Pajarito Mesa: this report.

Coppersmith, K. J., and Youngs, R. R., 1992, Modeling Fault Rupture Hazard for the Proposed Repository at Yucca Mountain, Nevada: in High Level Radioactive Waste Management, Proc. 3rd Ann. Conf., Las Vegas, Nevada, Amer. Nuc. Soc. and Amer. Soc. Civil Eng., p. 1142-1150.

Davenport, D. W., 1993, Micromorphology, Mineralogy, and Genesis of Soils and Fracture Fills on the Pajarito Plateau, New Mexico: Ph.D. Thesis, Texas Tech. Univ., Lubbock, 109 pp.

Kolbe, T., Sawyer, J., Gorton, A., Olig, S., Simpson, D., Fenton, C., Reneau, S., Carney, J., Bott, J., and Wong, I., 1994, Evaluation of the Potential for Surface Faulting at the Proposed Mixed Waste Disposal Facility, TA-67: unpublished report, Woodward-Clyde Federal Services, Oakland, California, 3 volumes.

Kolbe, T., Sawyer, J., Springer, J., Olig, S. „Reneau, S., Hemphill-Haley, M., and Wong, I., 1995, Evaluation of the Potential for Surface Faulting at TA-63: unpublished report, Woodward Clyde Federal Services, Oakland, California.

Reneau, S. L., Kolbe, T., Simpson, D., Carney, J. S., Gardner, J. N., Olig, S. S., and Vaniman, D. T., 1995, Surficial materials and structure at Pajarito Mesa: this report.

Vaniman, D., and Wohletz, K., 1990. Results of Geological Mapping/Fracture Studies: TA-55Area. Memo EES1-SH90-17. Amended in 1991 by Memo EES1-SH91-12; 50 pp, 1 plate 



\title{
POTENTIAL MESA-EDGE INSTABILITY AT PAJARITO MESA
}

\author{
by \\ Steven L. Reneau \\ Geology/Geochemistry Group \\ Los Alamos National Laboratory
}

\begin{abstract}
A geomorphic evaluation of part of Pajarito Mesa was undertaken to provide site-specific data on mass wasting processes pertinent to the siting of disposal pits at the proposed Mixed Waste Disposal Facility (MWDF). Mesa-edge instability varies between the north and south rims of Pajarito Mesa, and different setback criteria are appropriate for the opposite rims. The north rim displays large-scale mass movement features in a zone typically 30 to $60 \mathrm{~m}$ (100 to $200 \mathrm{ft}$ ) wide, and the zone of instability seems to occur along a part of Pajarito Canyon where a threshold combination of slope gradient and canyon depth has been exceeded. Future discrete slope failures of at least this size are possible. The frequency of failure is unknown, but seismic shaking may be an important triggering mechanism, and the timing of failure would thus be dependent on the timing of major earthquakes. A 15 to $30 \mathrm{~m}$ (50 to $100 \mathrm{ft}$ ) setback from the mass movement zone is recommended for the construction of disposal pits to avoid areas potentially susceptible to future failure. In contrast, mass wasting along the south rim seems to be dominated by the infrequent failure of narrow fracture-bounded tuff blocks, with an average block thickness of 1.0 to $1.3 \mathrm{~m}$ ( 3 to $4 \mathrm{ft}$ ) and a maximum block thickness of $6.1 \mathrm{~m}(20 \mathrm{ft})$. For similar cliffs at TA-21, the average period between such small rockfalls may exceed 10,000 years (Reneau, 1995). Available data indicates that a $15 \mathrm{~m}(50 \mathrm{ft})$ setback from the south mesa edge, as is used at Material Disposal Area G, TA-54, should be fully adequate to insure the integrity of disposal pits for periods exceeding 10,000 years. However, because of the probable temporal and spatial variability of cliff retreat, numerical estimates of cliff retreat rates are not considered reliable at this time.
\end{abstract}




\section{INTRODUCTION}

Pajarito Mesa is the proposed site for a Los Alamos National Laboratory (LANL) Mixed Waste Disposal Facility (MWDF). A geomorphic study of part of the mesa was undertaken to provide site-specific data on mass wasting processes pertinent to the siting of disposal pits, including the recommendation of appropriate setbacks from the mesa edges.

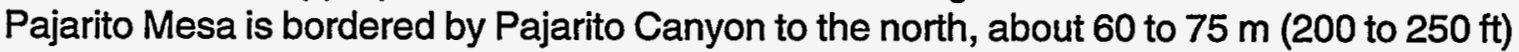
deep, and Threemile Canyon to the south, generally about $30 \mathrm{~m}$ (100 ft) deep (Figs. 1 and 2). The upper walls of both canyons are developed in resistant unit 3 of the Tshirege Member of the Bandelier Tuff (Fig. 2) (see geologic maps and stratigraphic clescriptions in Vaniman and Wohletz, 1990; Vaniman and Chipera, this report; Broxton et al., this report). The lower walls of Pajarito Canyon also include the cliff-forming unit 2 and overlying and underlying nonwelded tuff units. In Threemile Canyon, a broad, gently-sloping bench has developed on top of unit 2 beneath the upper cliffs, particularly to the east (Fig. $2 c$ ).

This study included field mapping of mass movement features and field observations of cliff retreat processes, and the analysis of topographic variations along the mesa margins and in the adjacent canyons. Measurements of canyon width were also used to provide estimates of average long-term cliff retreat rates, with these estimates being dependent on the validity of simple

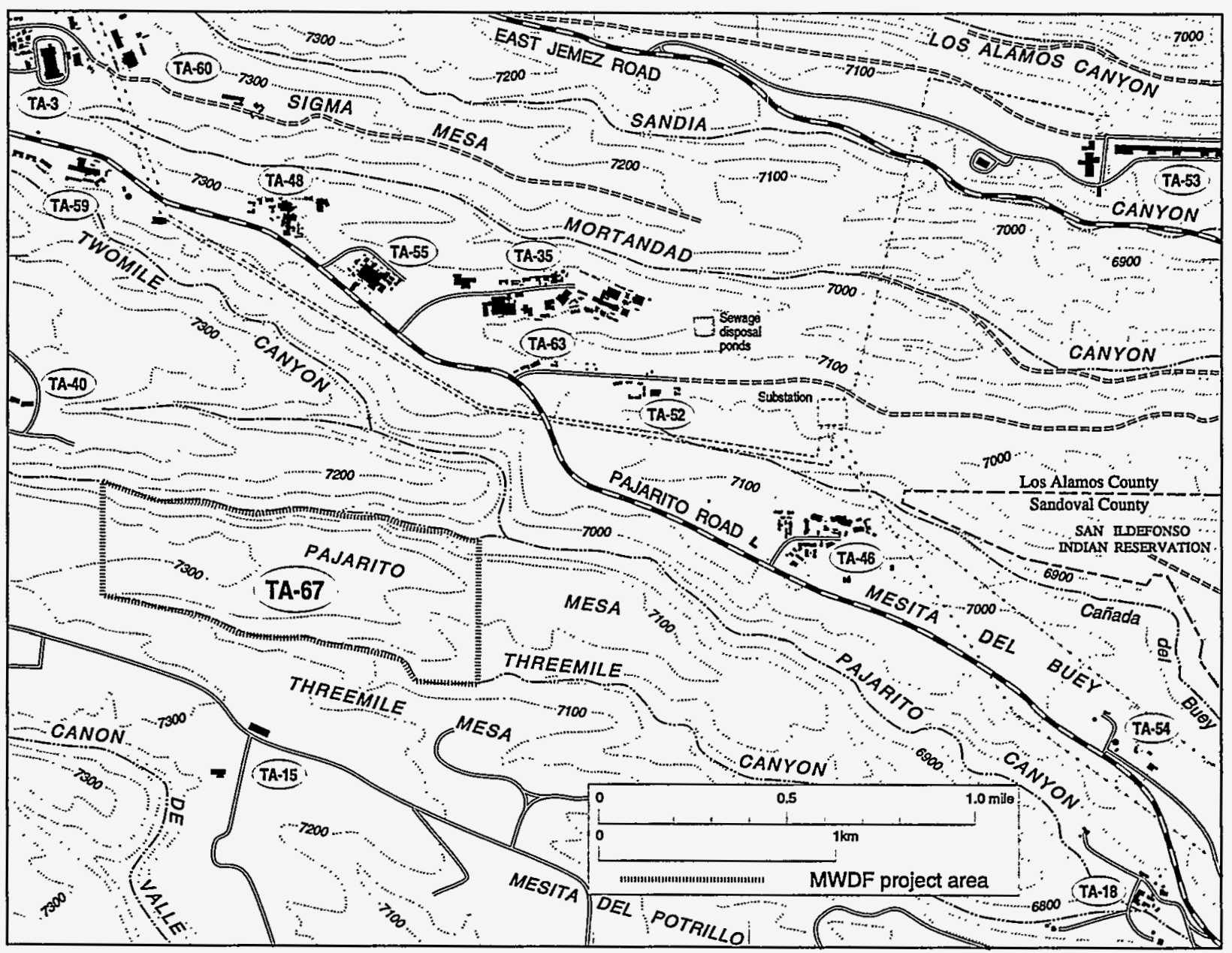

Fig. 1. Location of Pajarito Mesa study area and TA-67, the proposed MWDF site. Contour interval is 100 feet. 

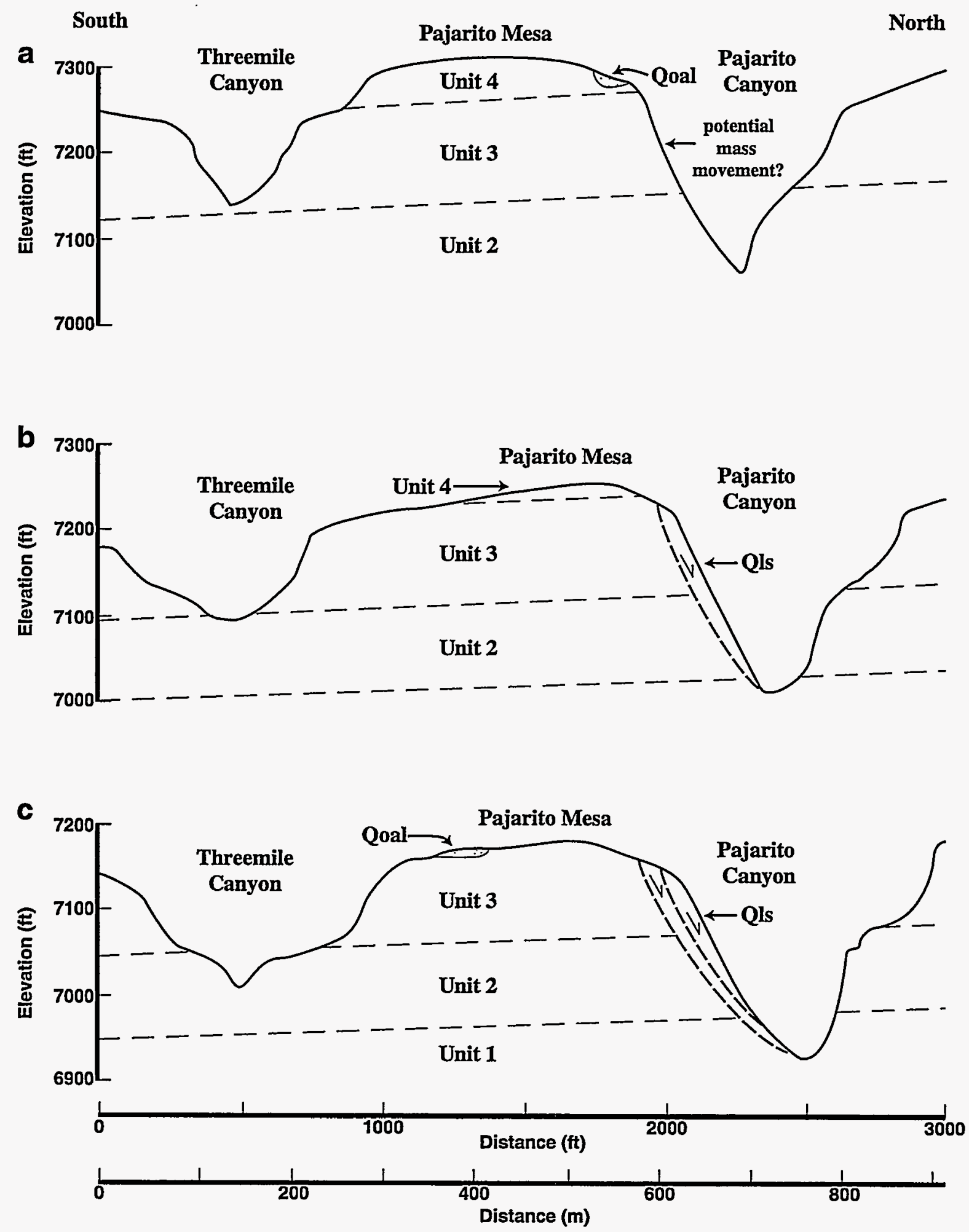

Fig. 2. North-south cross sections across Pajarito Mesa, showing deposits of mesa-top alluvium (Qoal), mass movement areas (QIs), and simplified units of the Tshirege Member of the Bandelier Tuff. a) West of proposed MWDF. b) Center of proposed MWDF. c) East of proposed MWDF. Topography from FIMAD topographic map. 
assumptions including constant retreat rates over time and incision beginning immediately after emplacement of the Bandelier Tuff. As used in this report, mass movement features include landslides, in which sliding of a large intact mass occurs above a basal failure surface; rockfalls, involving the dislodgment of individual fracture-bounded blocks from cliffs; and toppling failures, in which a section of cliff rotates outward away from the mesa (see Varnes, 1978, and Selby, 1982, for discussions of types of mass movement). The time period of interest for the MWDF is assumed to be 1000 to 10,000 years.

Investigation of the stability of mesa edges at Pajarito Mesa began with a traverse of both the north and south rims to identify the primary processes of mass wasting. The bottoms of Pajarito and Threemile Canyons were also traversed to check for evidence of recent, large-scale slope failures.

The character of the mesa edges differs between the north rim, bordering Pajarito Canyon, and the south rim, bordering Threemile Canyon, providing evidence for significant spatial differences in mass wasting processes. On the north rim large scale mass movement was identified, extending at least $60 \mathrm{~m}(200 \mathrm{ft})$ back from the mesa edge at its widest extent. The distribution of instability was mapped onto FIMAD (Facility for Information Management, Analysis, and Display) topographic maps with 2-foot contour intervals, and the mass movement features were described. On the south rim, large-scale mass movement features were not identified, with one possible exception, and the dislodgment of relatively narrow ( $<6 \mathrm{~m}$ or $20 \mathrm{ft}$ thick) blocks seems to be the predominant mechanism of cliff retreat. Measurements were made of the thickness of fracture-bounded blocks of tuff to constrain failure size.

\section{CANYON WIDTH AND CLIFF RETREAT RATES}

Knowledge of the rate of cliff retreat at Pajarito Mesa would allow estimates to be made of the length of time that disposal pits near mesa edges would be stable. However, reliable cliff retreat rates are difficult to obtain because of our short period of historic observation and because of the difficulty of quantifying cliff processes over periods of thousands of years, limiting the confidence of such estimates of stability. In addition, cliff retreat occurs by discrete failures of varying size that may be widely separated in time, and use of average retreat rates would thus be misleading for short time periods. The following calculations are thus not intended to provide precise, reliable retreat rates for long-term risk assessment, but instead to provide a comparison with estimates made elsewhere.

Measurements of the width of canyons on the Pajarito Plateau have previously been used to calculate long-term cliff retreat rates (Purtymun and Kennedy, 1971). These calculations assume that initial incision of the canyons occurred very soon after emplacement of the $1.22 \mathrm{Ma}$ (million year old) Tshirege Member of the Bandelier Tuff (age from Izett and Obradovich, 1994), and that since that time cliff retreat rates have been constant. However, these assumptions have not been tested, and cliff retreat rates calculated by this method must be used cautiously. For example, incision of the drainages through each unit of the Bandelier Tuff could have occurred significantly after 1.22 Ma, after deposition of mesa-top alluvium that is found on Pajarito Mesa and other mesas on the Pajarito Plateau (e.g., DP Mesa, Reneau, 1995). In addition, short-term and longterm rates of cliff retreat could be related to factors such as canyon depth, climate, and seismic activity, resulting in variable rates of cliff retreat over time.

Measurements of the width of Pajarito and Threemile Canyons were made from 1:1200 scale FIMAD maps, in order to evaluate spatial variations in canyon width that may provide insight into variations in cliff retreat. Canyon width was measured perpendicular to a center-line along the valley floor in each canyon, from the break-in-slope on the resistant part of Tshirege Member unit 3 or immediately overlying unit 4 on the edges of the adjacent mesas. The measurement locations 
were chosen to provide the maximum amount of variability, including both embayments where the canyons are widest and promontories where they are narrowest.

The canyons adjacent to Pajarito Mesa generally become narrower up-canyon (Fig. 3). These relations are typical for Pajarito Plateau canyons and are consistent with the headward development of the canyons over time and canyon incision that began later up-canyon than downcanyon (e.g., Reneau, 1995). Local measurements of canyon width may thus only provide minimum cliff retreat rates averaged over the past $1.22 \mathrm{Ma}$, and the highest rates would be calculated downcanyon where the canyons are widest. East of the proposed MWDF, near the eastern limit of unit 3 (the upper cliff-former at Pajarito Mesa), both canyons reach about $490 \mathrm{~m}$ (1600 ft) in width (Fig. 3), providing a minimum-limiting average rate of cliff retreat of $0.20 \mathrm{~m} / \mathrm{ky}(\mathrm{m} / 1000 \mathrm{yr})(0.66 \mathrm{ft} / \mathrm{ky})$ averaged over 1.22 Ma. Farther downstream along Pajarito Canyon at TA-54, Material Disposal Area (MDA) G, Purtymun and Kennedy (1971) estimated somewhat lower retreat rates of $0.14 \mathrm{~m} /$ ky $(0.45 \mathrm{ft} / \mathrm{ky})$ using similar measurements of canyon width.

Local variability in canyon width occurs in some areas on the Pajarito Plateau that suggests local variations in cliff retreat rates (Reneau, 1995). However, at Pajarito Mesa the widths of Pajarito and Threemile Canyons do not show great variability at the proposed MWDF, except for the general up-canyon decrease in canyon width (Fig. 3). Significant local variations in canyon width only occur along the adjacent canyons east of the proposed MWDF, beginning at the southward projection of the Guaje Mountain fault zone (as mapped by Vaniman and Wohletz, 1990; Vaniman and Chipera, this report), but the inferred variations in retreat rates to the east should not affect the proposed MWDF area.

\section{MASS MOVEMENT AREA ON NORTH RIM OF PAJARITO MESA}

An extensive area of instability occurs for about $1.8 \mathrm{~km}(6000 \mathrm{ft})$ along the north rim of Pajarito Mesa, roughly centered above the confluence of Twomile and Pajarito Canyons (Figs. 2, 4 , and Plate 4) and along the projected extension of the Guaje Mountain fault zone of Vaniman and Wohletz (1990) and Vaniman and Chipera (this report). Characteristics of the mesa edge here are significantly different from that present either east or west along the north rim, or to the south along the south rim.
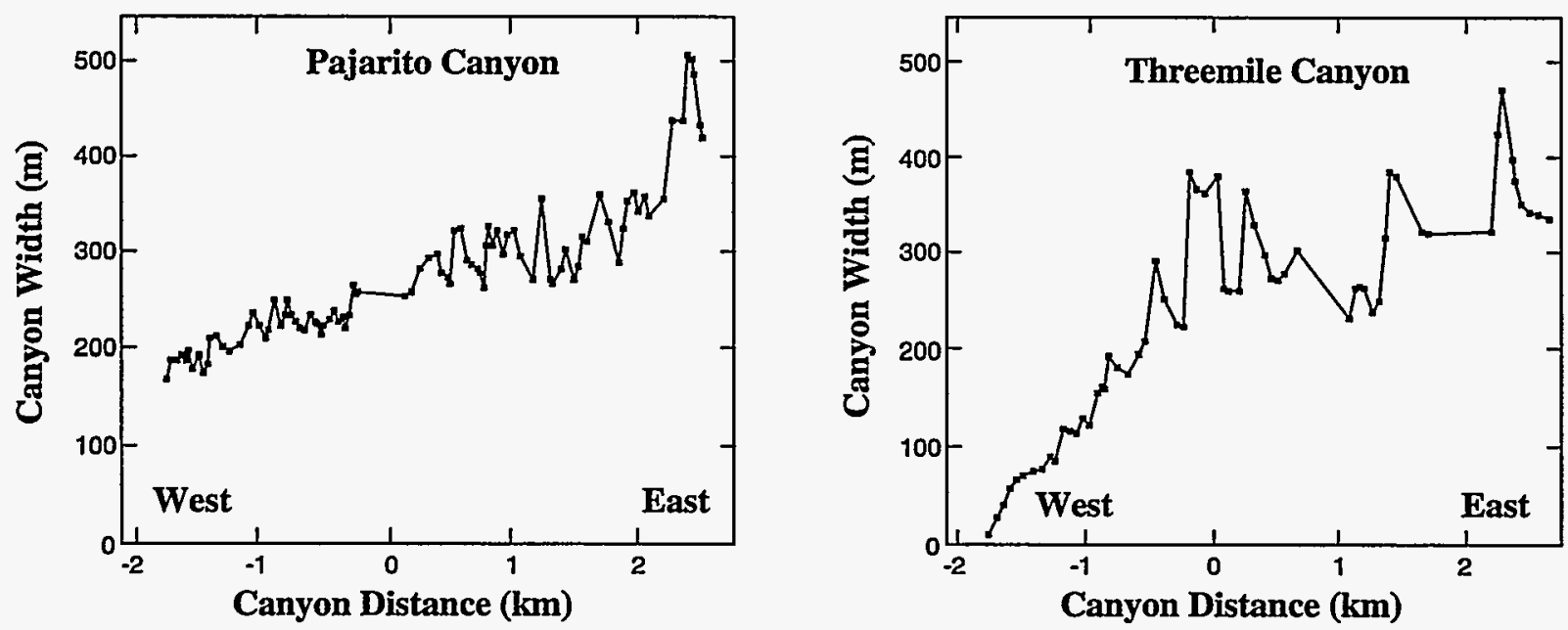

Fig. 3. Plots of total canyon width vs. distance along canyon for Pajarito and Threemile Canyons. Edge of canyon considered to be break in slope at top of cliff or steep slope developed on Tshirege Member unit 3. Canyon distance is measured relative to the confluence of Pajarito and Twomile Canyons. The proposed location of the MWDF disposal cell, as of June 1995, lies roughly at $-0.25 \mathrm{~km}$ to $-0.95 \mathrm{~km}$ on the distance scale. 


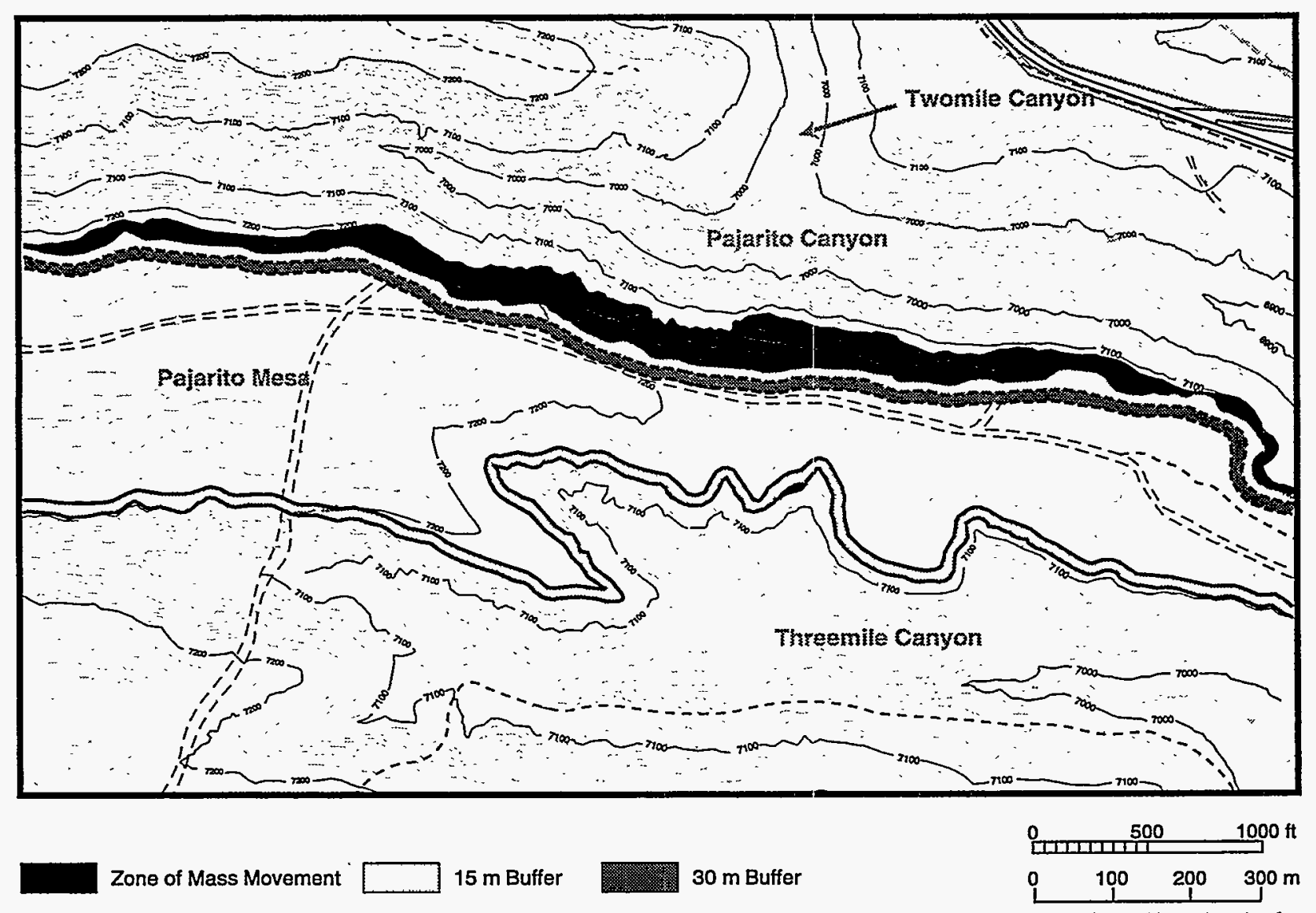

Fig. 4. Map of Pajarito Mesa showing mass movement areas and suggested $15 \mathrm{~m}(50 \mathrm{ft})$ and $30 \mathrm{~m}(100 \mathrm{ft})$ setbacks for disposal pits in vicinity of proposed MWDF. These features are shown at a scale of 1:1800 on FIMAD map G102049 and are also shown on Plate 4.

The clearest evidence for instability is along the immediate mesa rim. Multiple partiallydetached blocks, in part bounded by troughs on the south side that indicate mass movement towards the canyon, extend up to $30 \mathrm{~m}$ (100 ft) back from the mesa edge (Fig. 5). To the south, towards the center of Pajarito Mesa, the evidence for instability is more subtle, consisting of irregular "hummocks" of Bandelier Tuff that are probably bounded by fractures. The hummocks become less distinct to the south away from the canyon, and probably reflect lesser amounts of movement than occurred along the immediate mesa edge. The movement was apparently sufficient to step down fracture-bounded blocks of tuff towards Pajarito Canyon and to open up the intervening fractures, but insufficient to produce distinct, continuous scarps. Notably, the area of prominent mass movement is wider than the $15 \mathrm{~m}$ (50 ft) setback currently used for disposal pits at TA-54, MDA G (Purtymun et al., 1980), arguing for a larger setback from the north rim of Pajarito Mesa for the MWDF pits.

South of the area of hummocky topography, closer to the center of Pajarito Mesa, subtle steps exist that are possibly associated with the mesa-edge mass movement, and these were mapped to show the distribution of potential instability. The zone of mass movement shown in Figure 4 includes these subtle steps, and extends up to at least $60 \mathrm{~m}$ (200 ft) back from the mesa edge. It is possible that small movements $(<0.5 \mathrm{~m}$ or $1.6 \mathrm{ft})$ have occurred farther south, obscured by soil and vegetation, although the mapped mass movement zone was drawn conservatively and is believed to include the entire area of past movement.

The failure mechanisms for the mass movements along the north rim of Pajarito Canyon are not certain due to the small amounts of movement and the lack of exposure of failure surfaces 


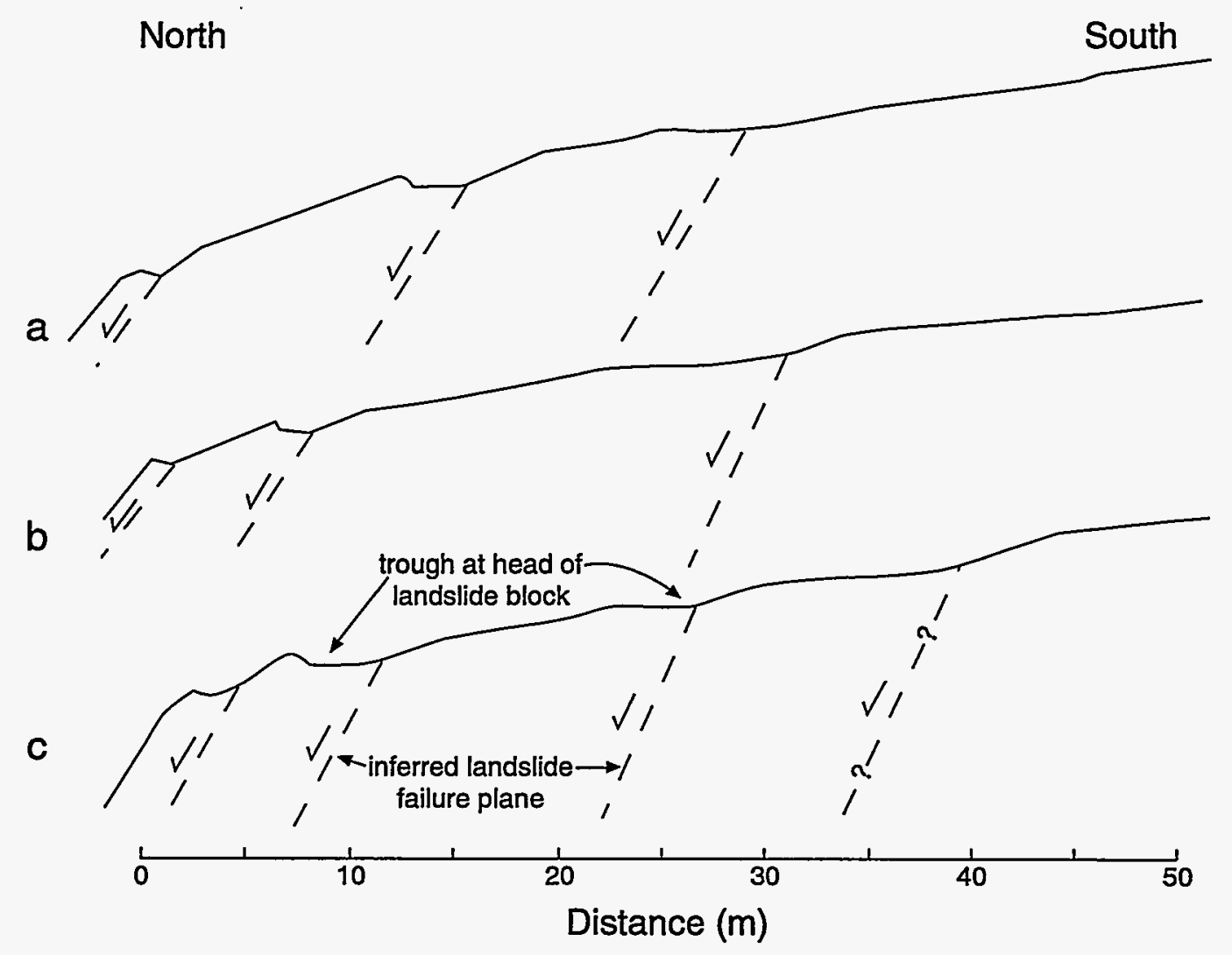

Fig. 5. Slope profiles measured along north rim of Pajarito Mesa in zone of mass movement. The back edges of partially-detached blocks are recognized by troughs oriented sub-parallel or obliquely to the mesa edge. a) Immediately east of proposed MWDF. b) Center of proposed MWDF. c) East of proposed MWDF, in widest part of mass movement zone. Profiles measured with tape, hand level, and stadia rod.

along the canyon wall, and failure may involve some combination of sliding and toppling. It is possible that the failure surfaces are curved at depth, causing a southward rotation of the blocks, as inferred for landslides in Bandelier Tuff along Los Alamos Canyon at TA-21 (Reneau, 1995). However, measured slope profiles (Fig. 5) indicate little to no net vertical displacement or southward rotation across some of the bounding troughs. Alternatives to rotational slides with curved failure surfaces include mass wasting dominated by toppling failures, in which detached blocks are rotated out towards the canyon, or translational slides with no block rotation, bounded by planar failure surfaces. Toppling failures or a combination of toppling and sliding failures typically characterize rock slopes in which the width of potential failure blocks is equal to or less than the slope height (Hoek and Bray, 1981), conditions that occur at Pajarito Mesa, and each of these failure mechanisms may be involved.

\section{SOUTH RIM OF PAJARITO MESA}

Observations of the south rim of Pajarito Mesa indicate that retreat of the mesa edges is dominated by small rockfalls that consist of single or multiple fracture-bounded blocks of tuff. Unlike the north rim, no continuous rim-parallel troughs are present, and instead the smooth profiles of the mesa edge are typically interrupted by short ( 0.3 to $0.6 \mathrm{~m}$ or 1 to $2 \mathrm{ft} \mathrm{high)} \mathrm{bedrock} \mathrm{steps} \mathrm{(Fig.}$ 6 ). These steps are probably produced largely by the physical disruption of fractured tuff by the toppling of trees. Shallow exposures in trench walls indicate that roots commonly grow between sub-horizontal sheets of fractured tuff, and evidence for the prying up of these sheets when trees 


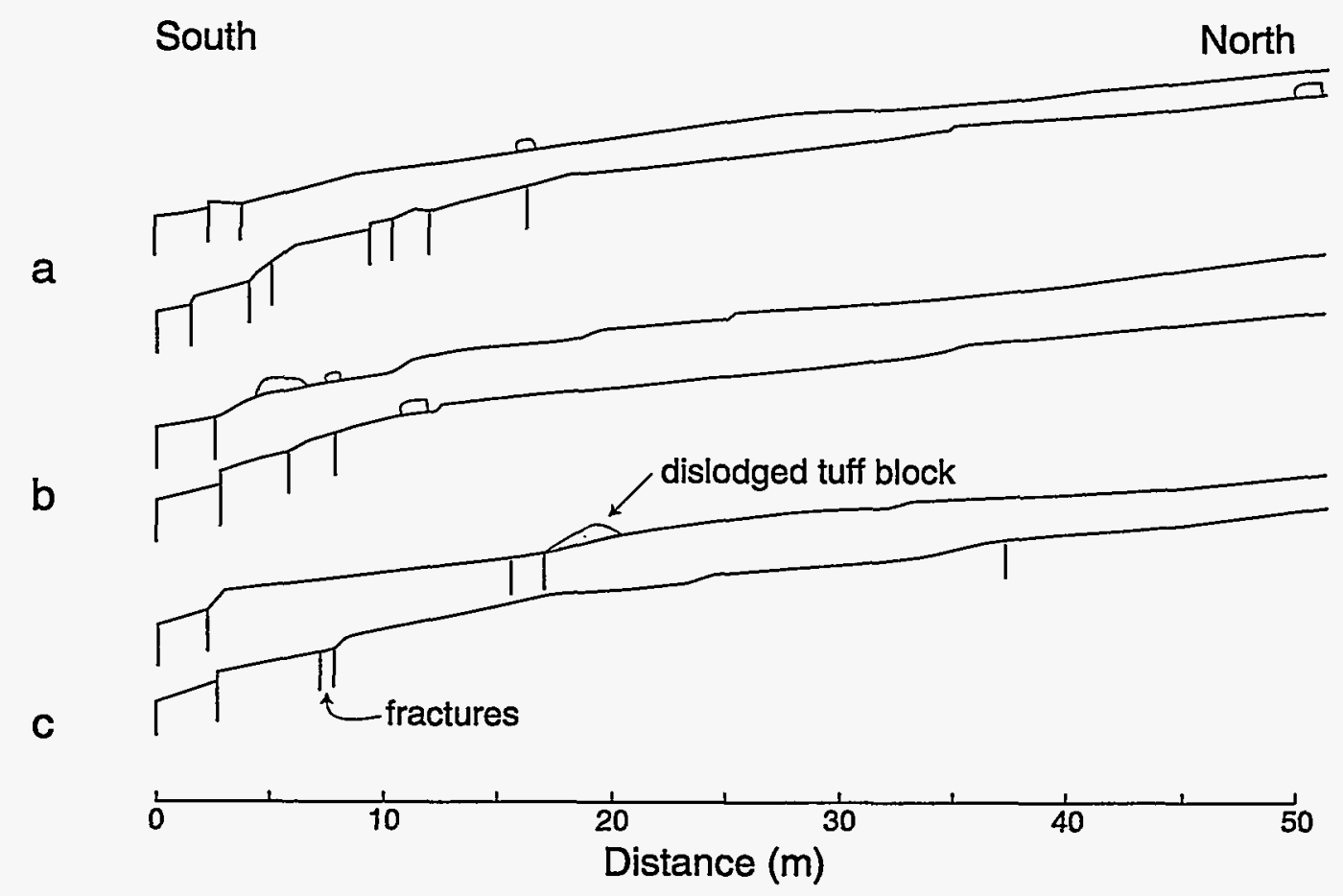

Fig. 6. Slope profiles measured along south rim of Pajarito Mesa. a) West part of proposed MWDF. b) Center of proposed MWDF. c) East part of proposed MWDF. Profiles measured with tape, hand level, and stadia rod.

topple is widespread on the margins of Pajarito Mesa. Such biogenic erosion appears to be the primary mechanism for vertical lowering of the bedrock surface near the mesa edges.

Evidence for large-scale mass movement, as seen on the north mesa edge, was only observed at one location on the south rim along a shallow tributary drainage to Threemile Canyon (Fig. 4). At this site, a block $11 \mathrm{~m}$ (35 ft) wide and $25 \mathrm{~m}$ (85 it) long, bounded by an arcuate step, appears to have dropped about $0.6 \mathrm{~m}(2 \mathrm{ft})$ towards the drainage. No other possible partiallydetached landslide blocks were observed, and no evidence for older failures of this scale, such as massive rockfall deposits, was found within Threemile Canyon. This block thus does not seem to be representative of cliff failure along the south rim of Pajarito Mesa.

Measurements of the thickness of fracture-bounded blocks in the unit 3 cliffs were made at two locations along Threemile Canyon in order to constrain the size of typical cliff failures. Similar measurements were not possible along Pajarito Canyon due to extensive colluvial cover. Along Threemile Canyon, the fracture-bounded blocks are typically small, with an average thickness of 1.0 to $1.3 \mathrm{~m}$ ( 3 to $4 \mathrm{ft}$ ) measured perpendicular to the cliff face and a median thickness of $0.7 \mathrm{~m} \mathrm{(2}$ ft) (Fig. 7). The distribution of block sizes is very similar between the two measurement sites (Fig. 7), and is also very similar to a site along similar unit 3 cliffs at TA-21 near MDA B (Reneau, 1995). With a $15 \mathrm{~m}$ (50 ft) setback, as used at MDA G, TA-54, failure of 12 to 16 average-sized blocks would be required before waste pits could be exposed. If failure occurred by the largest block measured $(6.1 \mathrm{~m}, 20$ feet), three failures would be required before a pit $15 \mathrm{~m}(50 \mathrm{ft})$ from the mesa edge would be exposed.

The typical block thickness measured along the south edge of Pajarito Mesa is very similar to the average fracture spacing of 1.1 to $1.2 \mathrm{~m} \mathrm{(3.5} \mathrm{to} 3.8 \mathrm{ft}$ ) in unit 3 of the Tshirege Member at Pajarito Mesa, as measured in trench exposures (Kolbe et al., 1994). This similarity suggests that most blocks on the cliff faces dislodge along cooling fractures or tectonic fractures, and that measurements along cliffs (e.g., Wohletz, 1995) can provide a good approximation of fracture density beneath mesas. Field observations of fractures along Pajarito Mesa cliffs had suggested 

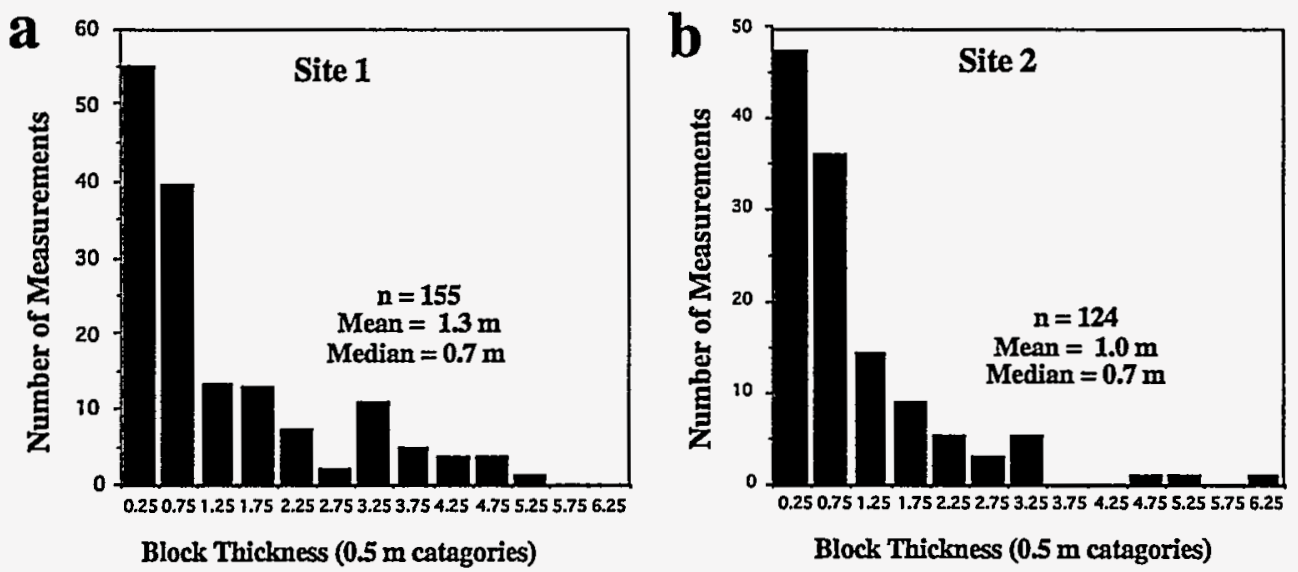

Fig. 7. Histogram of thickness of fracture-bounded blocks along cliff faces below south rim of Pajarito Mesa. Measurements of the distance from the cliff face back to the next fracture were made every $1 \mathrm{~m}$ in two embayments along the edge of Threemile Canyon, and represent the approximate thickness of individual rockfall blocks. These include both blocks bounded by primary cooling fractures and blocks bounded by secondary fractures produced by spalling.

that many of the measured fractures were related to weathering and spalling, but the comparison of trench data with cliff data indicates that fractures related to near-surface weathering are actually much less abundant than cooling fractures or tectonic fractures.

\section{TIMING OF MASS MOVEMENT}

No evidence is available on the age of the mass movement features on the north rim of Pajarito Mesa. Trees growing on the partially-detached blocks are not visibly affected by tilting or toppling, implying an age greater than 100 years. In addition, no evidence was seen along the floor of Pajarito Canyon for recent massive failures. Earthquake-triggered landsliding is well documented in other seismically-active regions (Keefer, 1984; Keefer and Wilson, 1989), and seismic shaking may similarly be an important triggering mechanism for large-scale mass movement along Pajarito Canyon due to the proximity of faults believed capable of generating Magnitude 7 earthquakes (Gardner and House, 1987; Wong et al., 1993, 1995).

If seismic shaking is the main triggering mechanism for the large-scale mass movements along the north rim of Pajarito Mesa, then estimates of the frequency of seismic shaking of various magnitudes provide constraints on the possible time scale of failure. Deterministic seismic hazard calculations indicate that Magnitude 7 earthquakes would cause peak ground accelerations of about $0.50 \mathrm{~g}$ for the central part of LANL, including mesa-top sites located a similar distance from the main scarp of the Pajarito fault system as Pajarito Mesa (i.e., TA-55) (Wong et al., 1995). Considerable uncertainty exists concerning the frequency of large earthquakes on the Pajarito Plateau, but the recurrence interval of Magnitude 7 events on the Pajarito fault system may be in the range of thousands to tens of thousands of years, in turn suggesting similar or longer time scales for the initiation of significant mass movement. However, the intensity of shaking sufficient to trigger movement on partially-detached blocks is unknown, and renewed movement could occur over shorter time scales caused by smaller magnitude earthquakes. For example, a probabilistic seismic hazard analysis suggests peak ground accelerations of about $0.30 \mathrm{~g}$ with 2000 year return periods and about $0.15 \mathrm{~g}$ for 500 year return periods for the central part of LANL (Wong et al., 1995), and such ground accelerations may be sufficient to destabilize some areas within the recognized zone of mass movement. 
Slope stability can also be influenced by climatic variations that affect the water content of slope-forming materials. Increases in water content cause decreases in rock and soil strength, and the north side of Pajarito Mesa may thus be more susceptible to mass movement failures during seasons or during extended periods with wetter climate and increased infiltration of water into fractures. However, the sensitivity of the amount and depth of infiltration on the Pajarito Plateau to climatic variations is poorly understood, and the significance of climatic fluctuations for slope stability at Pajarito Mesa cannot be assessed at this time.

\section{SPATIAL CONTROLS ON MASS MOVEMENT}

Evidence of large-scale mass movement is restricted to a $1.8 \mathrm{~km}$ long belt along the north rim of Pajarito Mesa (Fig. 4 and Plate 4), suggesting significant spatial controls on the mesa-edge instability. Several hypotheses were considered to explain this spatial distribution. First, as the most extensive area of mass movement is roughly centered along the southward projection of the Guaje Mountain fault zone (as mapped by Vaniman and Wohletz, 1990), a relation between mass movement and increased fracture density along this fault zone was suggested. However, data on mesa-penetrating fractures along the south margin of Pajarito Mesa show no significant increase in fracture density within this zone (Vaniman and Chipera, this report). In addition, data collected from trenches excavated across the projected fault zone at Pajarito Mesa (Kolbe et al., 1994) and to the north at TA-63 (Kolbe et al., 1995) also indicate no increase in fracture density. Explanations unrelated to variations in fracture density thus seem to be required.

A second hypothesis to explain the spatial distribution of mass movement features is that they are related to variations in the exposure of less stable rock units within Pajarito Canyon. The occurrence of large landslides along the north rim of Los Alamos Canyon at TA-21 has been interpreted to reflect the exposure of weaker, nonwelded tuff units beneath the resistant, cliffforming units along the canyon walls (Reneau, 1995). However, Pajarito Canyon is deepest east of the mass movement zone (Fig. 8), with a greater thickness of the nonwelded tuffs beneath resistant unit 2 exposed to the east (Fig. 2). Instability is thus not related solely to canyon depth at Pajarito Mesa.

A third hypothesis to explain the spatial distribution of landslides is that large-scale instability within the Bandelier Tuff requires a critical combination of canyon depth and canyon wall gradient, with increases in either canyon depth or wall gradient decreasing stability. This hypothesis is based on observations elsewhere that the stable gradient of rock slopes tends to decrease as the slope height increases, reflecting the greater shear stress at the base of longer slopes which results in increased fracturing in the rock and therefore lower shear strength (Selby, 1982).

For canyons with narrow alluvial floors, the average slope gradient of the canyon wall can be approximated by the ratio of canyon depth to canyon half-width, with canyon halfwidth being the horizontal distance from the

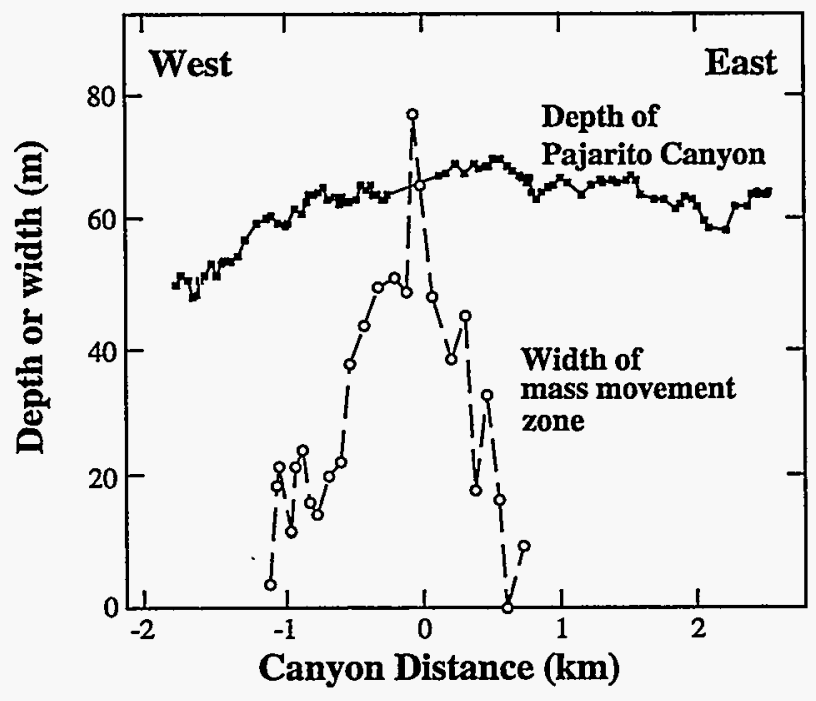

Fig. 8. Plot of canyon depth (solid squares) and width of mass movement zone (open circles) along north rim of Pajarito Mesa. Canyon depth is measured from the top of the resistant unit 3 cliffs or slopes to the stream channel on FIMAD topographic maps with 2-foot contours. Canyon distance is the same as in Fig. 3. 

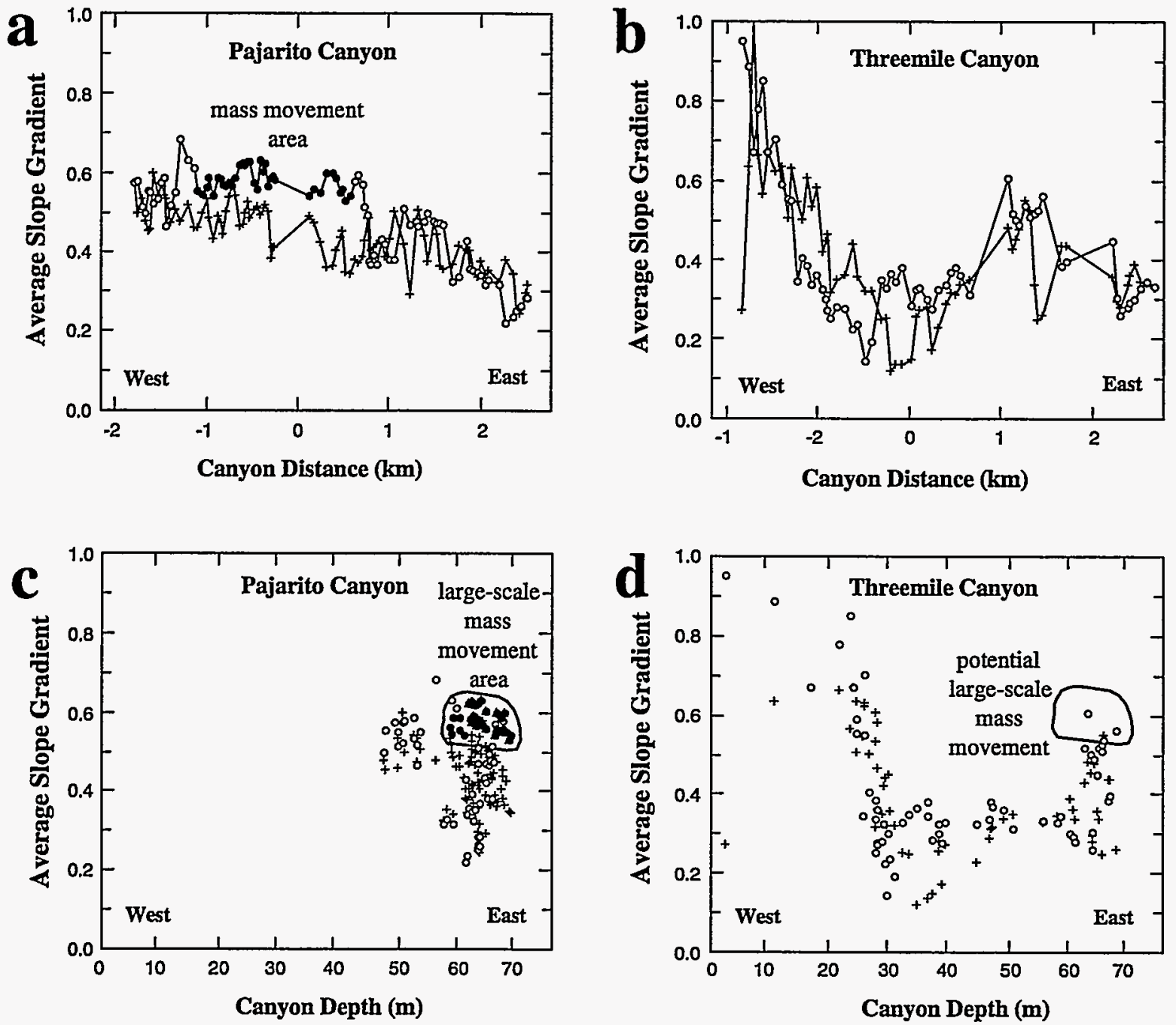

Fig. 9. Plots of average slope gradient vs. canyon distance for (a) Pajarito Canyon and (b) Threemile Canyon, and plots of average slope gradient vs. depth for (c) Pajarito Canyon and (d) Threemile Canyon. Open circles represent the south sides of the canyons, crosses represent the north sides, and solid circles designate the area along Pajarito Canyon where the zone of mass movement exceeds $15 \mathrm{~m}$ (50 ft) in width. Canyon depth and distance are the same as in Fig. 8.

canyon rim to the center of the valley floor. Average slope gradient is relatively high along the part of Pajarito Canyon that includes the zone of mass movement, and drops abruptly at the eastern end of the mass movement area (Fig. 9a), supporting the third hypothesis. Average slope gradient is also generally lower along the north rim of Pajarito Canyon and along both rims of Threemile Canyon, where no large mass movement features have been recognized, except for the head of Threemile Canyon and a short stretch of Threemile Canyon east of the proposed MWDF (Fig. 9a, b). On a plot of the average canyon wall gradient versus canyon depth for Pajarito Canyon, the zone of mass movement lies at one edge of the data field (Fig. 9c), where the canyon exceeds 58 $\mathrm{m}(190 \mathrm{ft})$ in depth and slope gradient exceeds 0.5 , suggesting a discrete domain of instability. These data thus suggest that part of the north rim of Pajarito Mesa, bordering Pajarito Canyon, has exceeded a stability threshold controlled by a combination of slope gradient and slope length (canyon depth), explaining the wide belt of instability that occurs there. Only a short stretch of Threemile Canyon lies within the domain of potential instability (Fig. 9d), occurring about $1.5 \mathrm{~km}$ (5000 ft) east of the proposed MWDF. The apparent existence of a threshold for instability suggests 
that rates of mesa-edge retreat could increase significantly once this threshold is exceeded, invalidating assumptions of constant retreat rates over time.

\section{RECOMMENDATIONS FOR PIT LOCATIONS}

Characteristics of the mesa edges, reflecting mass wasting processes, differ substantially between the north and south rims of Pajarito Mesa. The available data indicate that large, deepseated failures occur along the north rim, bordering Pajarito Canyon, whereas smaller-scale rockfall dominates erosion of the south rim, bordering Threemile Canyon. Consequently, the use of different setback criteria for pit locations is appropriate between the north and south rims.

Setbacks from the north rim of Pajarito Mesa should be large enough to avoid the zone of identified mass movement because of the potential for disrupting the integrity of disposal pits by renewed movement, such as during seismic events. In addition, because the zone of mass movement has probably migrated south towards the center of Pajarito Mesa and could extend farther into the mesa during future events, an additional buffer or setback is recommended. However, the desirable size of this buffer zone is not obvious because the failure process here is not fully understood. Incipient failure blocks are suggested by subtle steps that have been identified up to $15 \mathrm{~m}(50 \mathrm{ft})$ back from the more prominent mass movement steps, implying a minimum additional buffer of $15 \mathrm{~m}(50 \mathrm{ft})$ from any potential mass movement features to avoid future failures. A more conservative approach would be to double this setback to $30 \mathrm{~m}$ (100 ft). These suggested setbacks are shown on Figure 4 and Plate 4.

As a method of testing the adequacy of these buffer zones, the effects of mass movement of different sizes on the average canyon slope gradient, and hence on slope stability, were examined. Specifically, failure of the mesa edge would decrease the average slope gradient and therefore tend to make the canyon wall more stable, decreasing the potential for additional failures. Along much of the north side of Pajarito Mesa, complete failure of the mass movement zone mapped in Figure 4 would drop the average slope gradient below 0.5 , and thus remove those areas from the

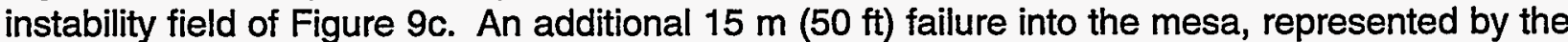
inner buffer zone of Figure 4 and Plate 4 , would reduce the slope gradient of all areas within the mass movement zone to below 0.5 , although peripheral areas to the east and west would still have gradients exceeding 0.5 and thus be potentially unstable. An additional $15 \mathrm{~m}(50 \mathrm{ft})$ failure, represented by the outer $30 \mathrm{~m}(100 \mathrm{ft})$ buffer zone of Figure 4 and Plate 4 , would remove all areas adjacent to the proposed MWDF from the instability field of Figure 9c. Therefore, based on our present knowledge of mass movement at Pajarito Mesa, use of a $30 \mathrm{~m}(100 \mathrm{ft})$ buffer should be fully adequate to keep the proposed disposal pits out of the area susceptible to large-scale slope failure.

Because of the relatively low potential for mass movement in the buffer zone, and also in the adjacent area of inferred incipient mass movement features, the buffer zones may be appropriate for non-critical facilities such as roads, parking areas, and temporary structures.

The available data indicates that the potential for massive slope failure along the south rim of Pajarito Mesa, involving more than several adjacent fracture-bounded blocks in a single event, is very low. A reasonable setback from the south rim should be large enough to accommodate multiple rockfalls or rockfalls involving multiple blocks, and thus be larger than the $6.1 \mathrm{~m}(20 \mathrm{ft})$ thickness of the largest measured fracture-bounded block. For other cliffs formed in unit 3 of the Tshirege Member at TA-21, adjacent to shallow canyons similar to Threemile Canyon in depth, available geologic evidence indicates that the period between individual rockfalls may exceed 10,000 years, and that disposal pits more than $15 \mathrm{~m}(50 \mathrm{ft})$ back from the mesa edges should be stable for time periods greatly exceeding 10,000 years (Reneau, 1995). A $15 \mathrm{~m}$ (50 ft) setback from the short cliffs bordering Mesita del Buey has been used for siting disposal pits at MDA G, TA54, since 1956 (see Purtymun and Kennedy, 1971; Rogers, 1977; Purtymun et al., 1980), and the 
available data indicate that a $15 \mathrm{~m}(50 \mathrm{ft})$ setback is also reasonable for the south edge of Pajarito Mesa. This suggested setback is shown on Figure 4 and Plate 4.

\section{ACKNOWLEDGMENTS}

This work was funded by the Los Alamos National Laboratory Environmental Restoration Program as part of site characterization activities for the proposed Mixed Waste Disposal Facility. The author thanks Paul Aamodt, Darrell Bultman, Bob Gillis, Chuck Harrington, and Dean Nelson for their support; Antonio Garcia for field assistance; Doug Walther with FIMAD for map preparation; Tony Garcia and Barry Moore for drafting support; and Chuck Harrington, Rúben Rangel, and John Wolff for review comments.

\section{REFERENCES}

Broxton, D.E., Vaniman, D., Byers, F. M., Jr., Chipera, S.J., Kluk, E.C., and Warren, R.G., 1995, Stratigraphy, mineralogy and chemistry of bedrock tuffs at Pajarito Mesa, this report.

Gardner, J. N., and House, L., 1987, Seismic hazards investigations at Los Alamos National Laboratory, 1984 to 1985: Los Alamos National Laboratory Report No. LA-11072-MS, Los Alamos, New Mexico, $76 \mathrm{p}$.

Hoek, E., and Bray, J., 1981, Rock Slope Engineering, 3rd Edition: London, Institution of Mining and Metallurgy, $358 \mathrm{p}$.

Izett, G.A., and Obradovich, J.D., 1994, ${ }^{40} \mathrm{Ar} /{ }^{39} \mathrm{Ar}$ age constraints for the Jaramillo Normal Subchron and the Matuyama-Brunhes geomagnetic boundary: Journal of Geophysical Research, v. 99 (B2), p. 2925-2934.

Keefer, D. K., 1984, Landslides caused by earthquakes: Geological Society of America Bulletin, v. 95, p. 406-421.

Keefer, D. K., and Wilson, R. C., 1989, Predicting earthquake-induced landslides, with emphasis on arid and semi-arid environments, in Landslides in a Semi-Arid Environment, With Emphasis on the Inland Valleys of Southern California, edited by P. M. Sadler and D. M. Morton. Publications of the Inland Geological Society, v. 2, p. 118-149.

Kolbe, T., Sawyer, J., Gorton, A., Olig, S., Simpson, D., Fenton, C., Reneau, S., Carney, J., Bott, J., and Wong, I., 1994, Evaluation of the Potential for Surface Faulting at the Proposed Mixed Waste Disposal Facility, TA-67: unpublished report for Los Alamos National Laboratory, Woodward-Clyde Federal Services, Oakland, California, 3 volumes.

Kolbe, T., Sawyer, J., Springer, J., Olig, S., Reneau, S., Hemphill-Haley, M., and Wong, I., 1995, Evaluation of the Potential for Surface Faulting at TA-63: unpublished report for Los Alamos National Laboratory, Woodward-Clyde Federal Services, Oakland, California, 3 volumes.

Purtymun, W. D., and Kennedy, W. R., 1971, Geology and hydrology of Mesita del Buey: Los Alamos Scientific Laboratory Report LA-4660, Los Alamos, New Mexico, 12 p.

Purtymun, W.D., Wheeler, M., and Warren, J.L., 1980, Guidelines for construction and use of solid waste disposal facilities at Area G, TA-54: Los Alamos Scientific Laboratory Memorandum H7-80-660, Los Alamos, New Mexico.

Reneau, S.L., 1995, Geomorphic studies at DP Mesa and vicinity: in Broxton, D. E., and Eller, P., G., eds., Earth Science Investigations For Environmental Restoration - Los Alamos National Laboratory Technical Area 21: Los Alamos National Laboratory Report LA-12934-MS, Los Alamos, New Mexico, p. 65-92.

Rogers, M.A., 1977, History and environmental setting of LASL near-surface land disposal facilities for radioactive wastes (Areas $A, B, C, D, E, F, G$, and T): A source document: Los Alamos Scientific Laboratory Informal Report LA-6848-MS, Vol. I. 
Selby, M.J., 1982, Hillslope Materials and Processes: Oxford University Press, Oxford, 264 p.

Vaniman, D., and Chipera, S., 1995, Mesa-penetrating fractures, fracture mineralogy, and projected fault traces at Pajarito Mesa: this report.

Vaniman, D., and Wohletz, K., 1990, Results of geological mapping/fracture studies: TA-55 area: Los Alamos National Laboratory Memorandum EES1-SH90-17, Los Alamos, New Mexico.

Varnes, D.J., 1978, Slope movement types and processes: in Schuster, R.L., and Krizek, R.J., eds., Landslides, Analysis and Control: Transportation Research Board Special Report 176, p. 12-33.

Wohletz, K., 1995, Measurement and analysis of rock fractures in the Tshirege member of the Bandelier Tuff along Los Alamos Canyon adjacent to TA-21: in Broxton, D. E., and Eller, P. G., eds., Earth Science Investigations For Environmental Restoration--Los Alamos National Laboratory Technical Area 21: Los Alamos National Laboratory Report LA-12934-MS, Los Alamos, New Mexico, p. 19-31.

Wong, I., Hemphill-Haley, M., Kolbe, T., Green, R., Bott, J., Kanakari, H., Kelson, K., Haraden, C., Gardner, J., House, L., Reneau, S., Keller, D., Silva, W., and Stark, C., 1993, Deterministic and probabilistic seismic hazard evaluation of the Los Alamos National Laboratory: Proceedings of Fourth DOE Natural Phenomena Hazards Mitigation Conference, Atlanta, GA, DOE Report CONF-9310102, v. 1, p. 258-267.

Wong, I., Kelson, K., Olig, S., Kolbe, T., Hemphill-Haley, M., Bott, J., Green, R., Kanakari, H., Sawyer, J., Silva, W., Stark, C., Haraden, C., Fenton, C., Unruh, J., Gardner, J., Reneau, S., and House, L., 1995, Seismic Hazards Evaluation of the Los Alamos National Laboratory: unpublished report, Woodward-Clyde Federal Services, Oakland, California, 3 volumes. 